UNIVERSIDADE DE SÃO PAULO

Faculdade de Direito

REGINA STELA CORRÊA VIEIRA

\title{
Saúde e Segurança no Trabalho das Mulheres: \\ A perspectiva de gênero para a proteção e promoção do meio ambiente laboral equilibrado
}

\author{
Dissertação de Mestrado \\ Orientador: Professor Dr. Homero Batista Mateus da Silva
}

São Paulo-SP

2014 


\title{
REGINA STELA CORRÊA VIEIRA
}

\section{Saúde e Segurança no Trabalho das Mulheres: \\ A perspectiva de gênero para a proteção e promoção do meio ambiente laboral equilibrado}

\begin{abstract}
Dissertação apresentada à Banca Examinadora do Programa de Pós-Graduação em Direito, da Faculdade de Direito da Universidade de São Paulo, como exigência parcial para a obtenção do título de Mestra em Direito, na área de concentração Direito do Trabalho e da Seguridade Social, sob a orientação do Professor Dr. Homero Batista Mateus da Silva.
\end{abstract}

Versão corrigida em 29/02/2015. A versão original, em formato eletrônico (PDF), encontra-se disponível na CPG da Unidade.

UNIVERSIDADE DE SÃO PAULO

FACULDADE DE DIREITO

SÃO PAULO-SP

2014 
Autorizo a reprodução e divulgação total ou parcial deste trabalho, por qualquer meio convencional ou eletrônico, para fins de estudo e pesquisa, desde que citada a fonte.

\author{
Catalogação na Publicação
}

Faculdade de Direito da Universidade de São Paulo

Vieira, Regina Stela Corrêa.

Saúde e Segurança no Trabalho das Mulheres: A perspectiva de gênero para a proteção e promoção do meio ambiente laboral equilibrado; orientador Homero Batista Mateus da Silva. - São Paulo, 2014.

$221 \mathrm{p}$.

Dissertação (Mestrado) - Departamento de Direito do Trabalho e Seguridade Social. Área de Concentração: Direito do Trabalho. 
Nome: VIEIRA, Regina Stela Corrêa.

Título: Saúde e Segurança no Trabalho das Mulheres: A perspectiva de gênero para a proteção e promoção do meio ambiente laboral equilibrado

Dissertação apresentada ao Departamento de Direito do Trabalho e da Seguridade Social da Universidade de São Paulo como requisito parcial para a obtenção do título de Mestra em Direito do Trabalho e da Seguridade Social.

Aprovada em: 01/12/2014

\section{BANCA EXAMINADORA}

Prof. Homero Batista Mateus da Silva

Julgamento:

Prof. Antonio Rodrigues de Freitas Júnior

Julgamento:

Prof(a). Patricia Tuma Martins Bertolin

Julgamento:
Instituição: Universidade de São Paulo

Assinatura:

Instituição: Universidade de São Paulo

Assinatura:

Instituição: Universidade Presbiteriana Mackenzie

Assinatura: 
Quebra coco nega, eu não, eu não, Quebra coco nega, eu tô quebrando.

A palmeira de sabida botou coco nas altura, Ela pensa que eu não sei, quando o coco tá maduro...

(canto das quebradeiras de coco do Maranhão)

Dedico esta dissertação às quebradeiras de coco babaçu, que trabalham sentadas na terra, com apenas um machado, o coco e as próprias mãos, e juntas entoam cantos para espantar a dor e a pobreza; e a todas as trabalhadoras. 


\section{AGRADECIMENTOS}

Agradeço ao professor Homero, que sempre me acolheu tão generosamente, incentivador da minha megalomania, responsável por me cativar pelo tema da saúde e segurança no trabalho. É uma honra tê-lo como orientador e um privilégio contar com a sua confiança. Espero que o Grupo de Pesquisa Seguridade Social, Gênero e Pobreza gere bons frutos.

Ao professor Jorge Luiz Souto Maior, por servir de inspiração e por refugiar jovens com ânsia de mudança, e ao Grupo de Pesquisa Trabalho e Capital, que agradeço em nome do Gustavo Seferian, Paulo Yamamoto, Ana Bianchi, Giovanna Souto Maior, Janaína de Castro, Francisco Costa e especialmente ao Noa Piatã, sempre perto, ainda que longe.

Ao CEBRAP e ao José Rodrigo Rodriguez, pelos conselhos nas horas certas, as repreensões contidas e a atenção concedida. Ao Seminário Maria de Lurdes Nascimento, grande fonte de inspiração e conhecimento, que se materializa no nome das grandes companheiras Natalia Neris e Gabriela Justino.

À professora Patrícia Tuma Martins Bertolin, pela acolhida e por incentivar amantes do feminismo e do Direito do Trabalho a persistirem nessa aventura.

Ao Grupo de Pesquisa Mulher, Sociedade e Direitos Humanos, em nome da Bruna Angotti, que generosamente aconselhou e trilhou caminho na floresta densa do pensamento feminista.

Ao professor Eduardo Saad Diniz, pelo apoio incomensurável.

À professora Nereida Salette Paulo da Silveira e ao professor Guilherme Guimarães Feliciano, presentes na banca de qualificação, pelas fundamentais contribuições a este trabalho.

À professora Helena Hirata, inspiração feminista, que acolheu em suas aulas mais uma aluna do Direito, ansiosa por compartilhar um pouco o seu conhecimento.

Aos professores e professoras da Faculdade de Direito, que me formam nessa arte, em especial ao professor Alessandro Octaviani, pelas conversas nas Arcadas e as preocupações a cada momento, e aos docentes do Departamento de Direito do Trabalho e da Seguridade Social, responsáveis pela semeadura do meu amor por esta disciplina. 
À Anna Paula Vencato, a mais querida amiga e mais presente inspiração, que em toda sua competência ainda tem tempo para incentivar esta iniciante.

Ao Dr. Roberto Rangel Marcondes, que vislumbrou tudo isso há muito tempo.

À $88^{\mathrm{a}}$ Vara do Trabalho, em nome da Isabel Fontana e do Luciano Schimdt, que me receberam nos primeiros dias do estágio na Justiça do Trabalho e recebem com todo carinho até hoje.

Ao professor Amauri Mascaro Nascimento, meu primeiro e admirado empregador, bem como às companheiras Claudete e Elaine e ao querido Tulio Massoni. Também ao Renan Quinalha, grande amigo e profissional, que ao longo do mestrado esteve sempre ao meu lado.

À Secretaria Municipal de Políticas para as Mulheres de São Paulo, em nome da Secretária Denise Motta Dau e da querida Vivian Mendes, e às companheiras Sarah de Roure, Ivete Garcia, Rita Quadros, Maria Lucia da Silveira, Patrícia Costa, Drika Souza, Phamela Godoy, que tive a sorte de conhecer.

Aos colegas de jornada, Thiago Castro, Farley Ferreira e Diego Petacci, e especialmente aos (já) doutores Flávio Higa, grande exemplo de dedicação e de ser humano, e Paulo Jakutis, por todo o apoio na reta final.

À melhor amiga do mundo, Marcela Purini, e ao tapete-rosa, pelas discussões sobre Bourdieu madrugada à dentro.

Às queridas amizades, por respeitarem a distância exigida pelos estudos e por estarem sempre por perto, em especial: Tatiana Tiemi, Mariana Palmitesta, Larissa Tunala, Mariana Nunes, Rafaela Junqueira, Yasmin Pestana, Rafaela Barbosa, Juliana Bueno, Aline Viotto, Bianca Tavolari, Talita Pessoa e Flavia Annenberg.

À Juliana Miasso, que cresceu comigo e me dá a felicidade de seu afeto sem limites, mesmo tendo preferido Paris à minha companhia.

À equipe do Braga \& Carvalho, Rachelle Balbinot, Jonnas Vasconcelos, Paula Zugaib, Marina Carvalho. Com destaque, minha gratidão ao Iagê Miola, que me amparou nos momentos de desespero da dissertação.

À minha família, em especial à Luiza Regina Coutinho Corrêa, que me fez gostar de ler desde pequenina, e à família do Marco, que também é minha, que agradeço em nome da querida Zulmira Braga. 
À Ladeira Caiowaa, minha segunda família, por me fazerem lembrar que a vida é boa: Valmir Vannucci, Murilo Vannucci, Cecilia Ugartemendía e todos mais que por ali passaram.

Ao Dandara e ao Fórum da Esquerda, por existirem, e à Carol Costa, por ter me dado o livro que revolucionou a pesquisa para este trabalho.

À Faculdade de Direito do Largo de São Francisco, pelas horas difíceis e pelos melhores momentos da minha vida, e aos funcionários e funcionárias, terceirizados e terceirizadas.

Ao Jean e sua técnica.

Ao Marco Aurélio Braga, pelo café no cansaço, o bom humor na reatividade e a ternura no abraço. Sem o seu carinho e a sua fé, pouco disso teria acontecido. Obrigada, meu amor, pelo seu companheirismo e por nosso harmonioso lar.

À minha irmã, Raquel Vieira, primeira mulher que vi se tornar. Agradeço por ser meu contraponto e meu complemento, por ter sempre me mostrado o lado leve e lindo da vida. Seguiremos juntas, sempre.

Peço a benção ao meu pai, Antonio Carlos Vieira, e através dele ao meu avô Raimundo e a todos meus ancestrais. Pai, obrigada pela vida, pelo amor, por ouvir Beatles comigo, por ter me ensinado a amar a natureza e a gostar das coisas mais valorosas que o mundo nos oferece. Amo você.

Peço a benção à minha mãe, Bárbara Corrêa, e através dela à minha avó, à minha bisavó e a todas as mulheres de nossa família. Obrigada, mãe, por ser meu raio de Iansã e por ter me ensinado que é preciso ser manha, graça e sonho, sempre. Amo você. 


\section{RESUMO}

Pensar na saúde e segurança no trabalho remete diretamente às medidas de proteção para evitar acidentes graves ou mortes em decorrência do trabalho, associadas a profissões geralmente masculinas. Os riscos ocupacionais a que as mulheres estão expostas são geralmente invisibilizados, fazendo crer que proteger "o trabalhador" é também proteger todas as trabalhadoras. No entanto, não existe o "indivíduo padrão", tampouco ciência neutra, pois quem necessita de proteção são seres humanos concretos, e o processo saúde-trabalho é mediado por fatores sociais, econômicos e culturais, em especial, pelas relações de gênero. A compreensão dessas imbricações só é possível com o emprego do gênero como categoria de análise do meio ambiente do trabalho, o que possibilita romper com a abordagem da saúde das mulheres trabalhadoras estritamente da perspectiva da maternidade ou da fragilidade. Esta dissertação propõe-se a ampliar o conhecimento das influências das relações de gênero na saúde e segurança no trabalho, desconstruindo naturalizações e estereótipos sobre feminilidade arraigados no Direito do Trabalho, na busca por compreender se as mulheres precisam de tutela especial, se sua saúde e segurança está de fato protegida pelas normas hoje vigentes e se essas normas promovem igualdade ou discriminação. Três grandes temas que interferem na relação das mulheres com o trabalho nos servirão de eixos para a análise das principais normas e questões trabalhistas que envolvem sua saúde e segurança: a maternidade; o corpo feminino e sua capacidade física; e a saúde mental. Objetiva-se contribuir para o aprofundamento da pesquisa acadêmica sobre a relação entre gênero e saúde e segurança no trabalho, bem como desconstruir preconceitos e apresentar algumas propostas para que as normas do Direito do Trabalho superem paradigmas sexistas e possam evoluir no sentido da promoção da igualdade entre homens e mulheres, essencial para a construção do equilíbrio do meio ambiente de trabalho.

Palavras-chave: saúde e segurança no trabalho; trabalho das mulheres; meio ambiente do trabalho; tutela especial; igualdade de gênero; divisão sexual do trabalho; equilíbrio ambiental; riscos ocupacionais. 


\begin{abstract}
To think about safety and health at work leads to inquiry what protective measures can prevent major accidents or deaths due to work, usually associated with professions dominated by men. The occupational hazards to which women are exposed are usually invisible, since it is believed that protecting "the worker" encompasses protecting all female workers. However, there is neither a "standard individual", nor a neutral science, because those who are in need of protection are concrete human beings, and the healthwork process is mediated by social, economic and cultural factors, in particular, gender relations. The understanding of these overlaps is only possible if gender is mobilized as a category of analysis of the work environment. Moreover, gender makes it possible to break with the approach of women's health at work strictly from the perspective of motherhood or fragility. This dissertation intends to extend the knowledge about the influence of gender relations on safety and health at work, and to deconstruct naturalizations and stereotypes built around femininity that are rooted in Labour Law. It seeks to understand whether women need special protection, if their health and security is actually protected by today's current standards, and if those standards promote equality or discrimination. Three major themes that mediate the relationship between women and work guide the analysis of the main standards and labor issues involving their safety and health: motherhood; the female body and its physical ability; and mental health. This work aims at contributing to the scholarship on the relationship between gender and safety and health at work, as well as to deconstruct prejudices and present some proposals for labor law standards to overcome sexist paradigms towards the promotion of gender equality - an essential condition to the construction of a balanced work environment.
\end{abstract}

Keywords: safety and health at work; women's work; the work environment; special guardianship; gender equality; sexual division of labor; environmental balance; occupational hazards 


\section{LISTA DE ABREVIATURAS}

ACGIH

ADCT

CEDAW

CID

CF

CLT

EPI

Fundacentro

INSS

LER/DORT

MTE

NR

NTEP

OIT

OMS

ONU

PCMSO

PL

PPRA

STF

SUS

TST

TVLs
American Conference of Governmental Industrial Higyenists

Ato das Disposições Constitucionais Transitórias

Convenção das Nações Unidas sobre a Eliminação de Todas as Formas de Discriminação contra a Mulher

Classificação Internacional de Doenças

Constituição da República Federativa do Brasil de 1988

Consolidação das Leis do Trabalho

Equipamento(s) de Proteção Individual

Fundação Jorge Duprat de Segurança e Medicina do Trabalho

Instituto Nacional do Seguro Social

Lesões por esforços repetitivos / Distúrbios Osteomusculares Relacionados ao Trabalho

Ministério do Trabalho e Emprego

Normas Regulamentadoras do Capítulo V, Título II da CLT, relativas à segurança e medicina do trabalho

Nexo Técnico Epidemiológico Previdenciário

Organização Internacional do Trabalho

Organização Mundial da Saúde

Organização das Nações Unidas

Programa de Controle Médico de Saúde Ocupacional

Projeto de Lei

Programa de Prevenção de Riscos Ambientais

Supremo Tribunal Federal

Sistema Único de Saúde

Tribunal Superior do Trabalho

Threshold Limit Values, índices seguros de exposição ocupacional a agentes químicos e físicos, editados pela ACGIH 


\section{SUMÁRIO}

Introdução. 14

Capítulo 1. A perspectiva de gênero no ambiente do trabalho 23

1.1. A igualdade entre os sexos como eixo para o meio ambiente equilibrado...................... 23

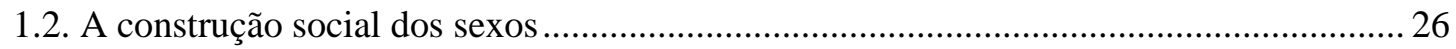

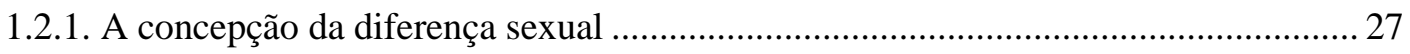

1.2.2. Gênero, relações sociais de sexo e divisão sexual do trabalho...................................... 36

1.2.3. A atenção à diferença como meio de combater a desigualdade ................................ 44

1.3. A influência do gênero sobre os riscos ocupacionais ......................................................... 48

1.3.1. A organização do trabalho e segregação ocupacional por sexo .................................. 49

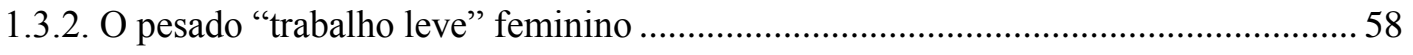

1.3.3. A predominância dos trabalhos precários entre as mulheres...................................... 62

1.4. Uso da categoria gênero no estudo da saúde e segurança do trabalho .............................. 66

\section{Capítulo 2. Normas de saúde e segurança do trabalho das mulheres: da} proibição à proteção................................................................................... 73

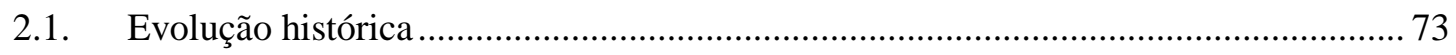

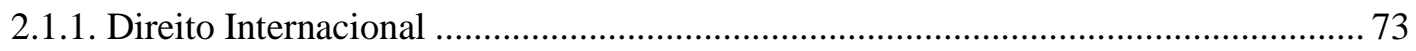

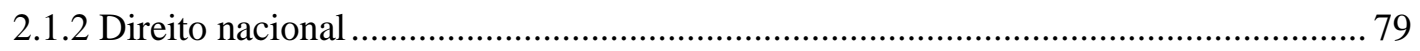

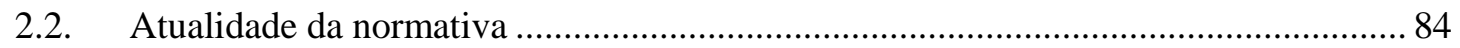

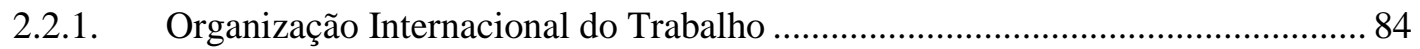

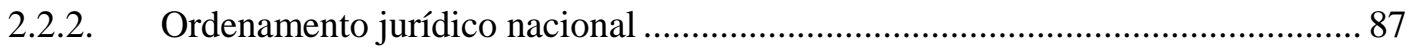

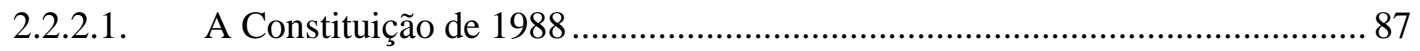

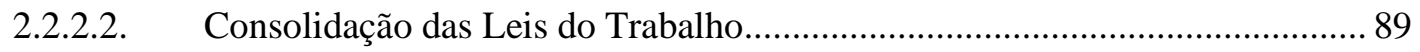

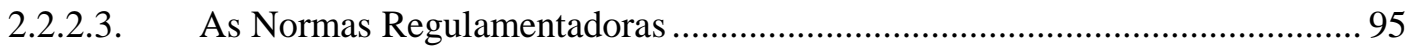

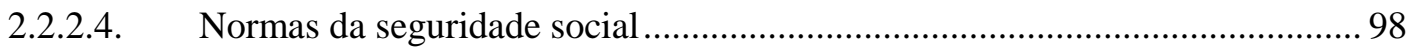

2.3. O olhar biologicista e sexista do Direito sobre o trabalho das mulheres.................... 101

2.4. A falsa neutralidade dos conceitos em saúde e segurança ......................................... 106

Capítulo 3. Maternidade, saúde e segurança no trabalho......................111

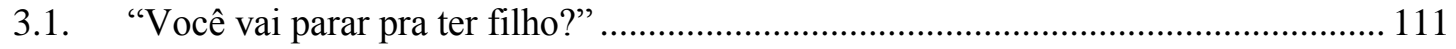

3.2. A deficiente legislação brasileira de proteção às trabalhadoras-mães........................ 120

3.2.1. Licença à gestante, licença-paternidade, salário-maternidade e a reprodução da

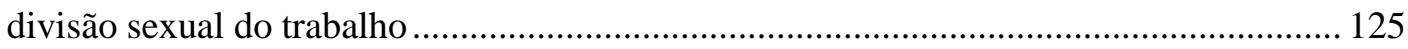

3.3. Proteção específica às trabalhadoras-mães.............................................................. 129 


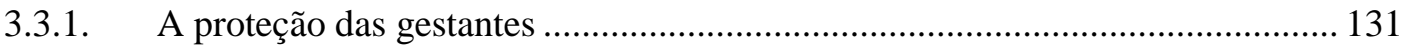

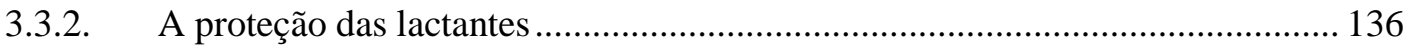

3.4. Meios jurídicos para a garantia do direito ao trabalho das mulheres que decidem ter filhos ou filhas e amamentar 140

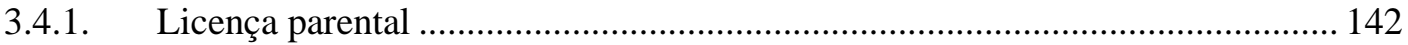

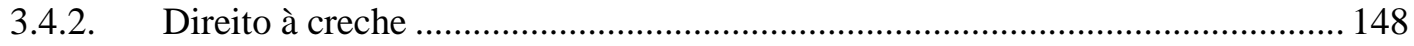

\section{Capítulo 4. Ergonomia e o corpo das mulheres em face dos riscos} ocupacionais ................................................................................................................. 153

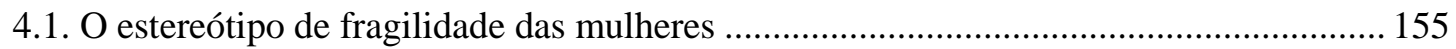

4.1.1. A divisão sexual dos limites de carga ……....................................................... 159

4.1.2. O intervalo de 15 minutos pré-jornada extraordinária ........................................ 163

4.2. A inadequação de maquinário e equipamentos para trabalhadoras ............................. 168

4.3. LER/DORT e o mito da "doença feminina" ................................................................ 170

4.4. O paradigma da variabilidade humana individual................................................... 175

Capítulo 5. A saúde mental das mulheres trabalhadoras ..................... 177

5.1. A construção sexista da instabilidade feminina ...................................................... 177

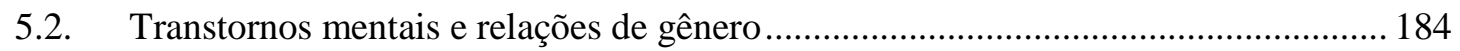

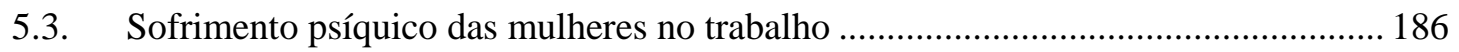

5.3.1. O papel social das mulheres como fator de sobrecarga e estresse .................... 188

5.3.2. Violência psicológica, assédio moral e sexual no trabalho ................................. 191

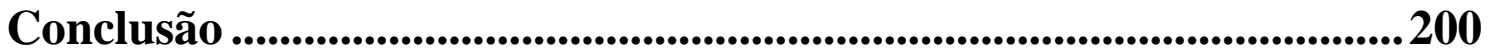

Bibliografia........................................................................................................... 203 


\section{Introdução}

Desde o século XIX, quando pela primeira vez houve a necessidade do Estado regular as relações de trabalho, o Direito do Trabalho é vinculado à proteção de trabalhadoras e trabalhadores contra condições degradantes de trabalho. Se, no contexto da Revolução Industrial e do liberalismo econômico, as primeiras normas trabalhistas teriam sido forjadas para proteger mulheres e crianças da exploração extremada, do que decorria um grande número de acidentes fatais e reduzida expectativa de vida, hoje em dia o ordenamento jurídico trabalhista ainda precisa controlar os graus de exploração e garantir a saúde e segurança no trabalho.

Apesar dos avanços civilizatórios e jurídicos, no âmbito das relações entre capital e trabalho, e do desenvolvimento tecnológico, que aumentou a segurança das máquinas e permitiu a evolução de métodos de prevenção de acidentes e de controle de agentes danosos para o organismo humano, é alarmante a estimativa de que 2,3 milhões de pessoas morrem todos os anos no mundo em virtude de acidentes e doenças relacionados com o trabalho e mais 160 milhões padecem de doenças não letais ligadas à atividade profissional. ${ }^{1}$

No Brasil, a cada 60 minutos, morre uma trabalhadora ou trabalhador em consequência de acidente do trabalho. Mesmo com as altas taxas de subnotificação e de informalidade, os dados do Ministério da Previdência Social mostram que, no ano de 2009, foram registrados 723.452 acidentes e doenças do trabalho entre seguradas ou segurados do INSS. Entre essas pessoas, a maior parte foi afastada de suas atividades laborais devido à incapacidade temporária, mas 13.047 foram consideradas com incapacidade permanente e 2.496 perderam suas vidas em consequência do trabalho. ${ }^{2}$

Diante disso, fica patente a importância central da disciplina da saúde e segurança para o Direito do Trabalho, que, orientada pelos princípios da prevenção e precaução, visa à proteção de todos os seres humanos contra os riscos relacionados ao trabalho, promovendo o equilíbrio labor-ambiental. O horizonte almejado aqui é o da

\footnotetext{
${ }^{1}$ ORGANIZAÇÃO INTERNACIONAL DO TRABALHO. A prevenção das doenças profissionais. Genebra: OIT, 2013. p. 4.

${ }^{2}$ BARRETO, Margarida; HELOANI, Roberto. Assédio laboral e as questões contemporâneas à saúde do trabalhador. In: LOURENÇO, Edvânia Ângela De Souza; NAVARRO, Vera Lucia (orgs.). O avesso do trabalho III: saúde do trabalhador e questões contemporâneas. São Paulo: Outras expressões, 2013. p. 107-141. p. 108-109.
} 
definição, da Organização Mundial da Saúde, de saúde não apenas como ausência de doença, mas como estado de completo bem-estar físico, mental e social. ${ }^{3}$

No entanto, ao falarmos da tutela jurídica do meio ambiente de trabalho saudável e seguro, vem-nos à mente a busca pela proteção da força de trabalho dos riscos de acidentes graves, por exemplo, na construção civil, em minas e garimpos ou em indústrias pesadas, isto é, pensamos em trabalhadores do sexo masculino exercendo "trabalho pesado". Não vinculamos os riscos laborais às mulheres ou às profissões geralmente relacionadas a elas, como serviços de saúde, de educação e o trabalho doméstico.

Nota-se que o trabalho feminino e os riscos a ele relacionados são praticamente invisíveis na área de saúde e segurança do trabalho, que continua "focalizando grupos ocupacionais majoritariamente masculinos". ${ }^{4} \mathrm{E}$ essa invisibilidade ocorre em todos os ramos da ciência, que submetem as mulheres a uma definição universal, de modo a desconsiderar e mascarar, sob o manto dos direitos humanos, as desigualdades reais existentes na sociedade.

Afinal, não existe o "homem em geral". Por conseguinte, os sujeitos dos direitos universais são seres humanos concretos, inseridos de formas diferenciadas na hierarquia social e nas relações de poder, de modo que "o princípio da universalidade dos direitos só pode se realizar se corresponder à diversidade e à pluralidade de experiências de opressão e de injustiça". 5

A ciência, portanto, não é neutra e o processo saúde-trabalho é mediado e transversalizado por uma série de fatores sociais, econômicos e culturais, dentre os quais, pelas relações de gênero. ${ }^{6}$ Assim, apesar da escassa literatura sobre saúde e segurança no trabalho das mulheres, o aumento força de trabalho feminina nas últimas décadas chamou a atenção para questões de gênero nas diferentes formas de

\footnotetext{
${ }^{3}$ ORGANIZAÇÃO MUNDIAL DA SAÚDE. Constitution of the World Health Organization. New York: OMS, 1948. Disponível em <http://www.who.int/governance/eb/who_constitution_en.pdf>. Acesso em: 10.jun.2013.

${ }^{4}$ CORRÊA, Sônia. Gênero e saúde: campo em transição. BRUSCHINI, Cristina; UNBEHAUM, Sandra G. (orgs.). Gênero,democracia e sociedade brasileira. São Paulo: FCC: Editora 34, 2002. p. 357-388

${ }^{5}$ VARIKAS, Eleni. Universalismo e particularismo. In: HIRATA, Helena; LABORIE, Françoise; LE DOARÉ, Hélène; SENOTIER, Danièle (org.). Dicionário Crítico do Feminismo. São Paulo: Editora Unesp, 2009. p. 266-271.

${ }^{6}$ OLIVEIRA, Eleonora Menicucci de. A mulher, a sexualidade e o trabalho. São Paulo: CUT, 1999. p. 27.
} 
adoecimento e no modo como os riscos e demais fatores labor-ambientais afetam trabalhadoras e trabalhadores.

Só é possível compreender a saúde e segurança das trabalhadoras se conjugarmos uma série de aspectos que envolvem suas vidas: no trabalho, é preciso analisar o tipo de ocupação, o ritmo de trabalho, a atenção do sindicato às suas reivindicações, a estabilidade no emprego e a distância entre casa e serviço; na vida social e familiar, é preciso considerar classe, raça, idade, papéis desempenhados na família etc. A junção de todos esses fatores interfere na saúde de cada indivíduo, com diferentes impactos. Por conta disso, muitas mulheres acabam tendo problemas semelhantes devido à proximidade de modos de vida.

A compreensão dessas questões exige o emprego do gênero como categoria de análise do meio ambiente do trabalho, o que possibilita romper com a abordagem da saúde das mulheres trabalhadoras estritamente da perspectiva da maternidade ou da fragilidade, "possibilitando evidenciar a esfera da subjetividade e sexualidade como aspectos fundamentais para a promoção da qualidade de vida e consequente equilíbrio entre saúde e trabalho". 7

Tomar a perspectiva de gênero permite esclarecer fenômenos como a elevada mortalidade masculina na faixa etária produtiva, ao explorar a construção de identidade que leva a atitudes arriscadas ou violentas, ou como a alta morbidade feminina registrada, cujas causas podem ser desde um desgaste agravado pela dupla jornada até a reiterada demanda de serviços pela excessiva mediocrização dos processos produtivos. Permite, ainda, uma melhor leitura de alguns aspectos da vivência das mulheres no trabalho, que demonstram que a legislação atual ou é ineficaz ou insuficiente para levar um tratamento igualitário a ambos os sexos.

Nesse sentido, entre as tendências e desafios mundiais na segurança e saúde do trabalho apontados no XIX World Congress on Safety and Health at Work, em 2011, foi destaque o gender-mainstreaming, baseado na ideia de que reconhecer a diferença e diversidade é essencial para a promoção de locais de trabalho saudáveis para todas e todos, considerando que os efeitos dos papéis de gênero na saúde precisam ser

\footnotetext{
${ }^{7}$ OLIVEIRA, Eleonora Menicucci de. Corpos saudáveis e corpos doentes na nova organização social do trabalho. In: ROCHA, Maria Isabel Baltar da. (org). Trabalho e Gênero: Mudanças, Permanências e Desafios. São Paulo: Editora 34, 2000.p. 237-256.
} 
explorados para uma melhor compreensão da relação entre saúde ocupacional e os papéis sociais e econômicos de homens e mulheres. ${ }^{8}$

Dessa forma, o Direito do Trabalho precisa incorporar a compreensão de que a saúde no trabalho é expressão de condições sociais, culturais e históricas, dentre as quais, as relações sociais de sexo. Assim, é fundamental que cultivemos a prática de pensar o ordenamento jurídico trabalhista com o olhar de gênero, buscando abrir os horizontes da proteção à saúde e segurança no trabalho das mulheres para além da proteção da maternidade e dos estereótipos de feminilidade.

Esse passo é especialmente importante uma vez que não há como avançarmos na proteção dos Direitos Humanos sem progredir em termos de relações de gênero. Nesse quesito, infelizmente, o Brasil ainda deixa a desejar: o Índice de Desigualdade de Gênero, divulgado pelo Programa das Nações Unidas para o Desenvolvimento (PNUD) - calculado com base na taxa de mortalidade materna, taxa de fertilidade adolescente, assentos parlamentares ocupados por mulheres, porcentagem de mulheres com pelo menos o ensino secundário completo e taxa de participação feminina na força de trabalho -, coloca nosso país em $85^{\circ}$ lugar na classificação entre 148 países. Apesar de no Índice de Desenvolvimento Humano (IDH) o Brasil ocupar a mesma $85^{\mathrm{a}}$ posição, a nota do país em equidade de gênero é apenas 0,447 , frente à nota 0,730 no IDH geral. ${ }^{9}$

A igualdade entre homens e mulheres não é secundária, mas parte intrínseca das relações humanas, de modo que é uma das instâncias para as quais o Direito precisa colocar atenção. Especialmente em relação à saúde e segurança no trabalho, a perspectiva de gênero permite vislumbrar, conforme exemplifica a OIT, que proibir o emprego de mulheres em certos tipos de trabalho classificados como perigosos, sob a justificativa de proteger sua saúde e segurança, apesar de parecer louvável, pode contribuir para discriminação de gênero no trabalho, por deixar de

\footnotetext{
${ }^{8}$ ORGANIZAÇÃO INTERNACIONAL DO TRABALHO. Introductory report: global trends and challenges on occupational safety and health: XIX World Congress on Safety and Health at Work: Istanbul Turkey, 11-15 September 2011. Genebra: OIT, 2011.

9 PROGRAMA DAS NAÇÕES UNIDAS PARA O DESENVOLVIMENTO. Relatório do Desenvolvimento Humano 2013. New York: PNUD, 2013. p. 162-165. Disponível em: <http://www.pnud.org.br/HDR/arquivos/RDHglobais/hdr2013_portuguese.pdf>. Acesso em: 15.ago.2014.
} 
proteger os homens dos riscos e/ou negar acesso igualitário das mulheres ao mercado de trabalho. ${ }^{10}$

Desse modo, apesar de sabermos que alterações no mundo jurídico não irão romper com a opressão de gênero, uma vez que o Direito é apenas parte das estruturas de dominação, entendemos que deixar de reproduzir o sexismo nesta esfera é parte fundamental do processo de busca pela igualdade entre mulheres e homens. Aderimos, assim, à proposta de Márcio Tulio Viana, de "usar o Direito como instrumento de transformação social". ${ }^{11}$

Diante de todo o apresentado, o presente estudo se propõe a ampliar o conhecimento das influências das relações de gênero na saúde e segurança no trabalho, desvelando e desconstruindo naturalizações e estereótipos sobre feminilidade e masculinidade arraigados no Direito do Trabalho, com o objetivo de responder a três questões centrais: As mulheres precisam de tutela especial no Direito do Trabalho, por meio de regras voltadas especificamente às trabalhadoras do sexo feminino, tal como acontece hoje? A saúde e a segurança das trabalhadoras estão realmente protegidas pela legislação vigente? As atuais normas a esse respeito promovem igualdade ou discriminação?

Dessa forma, buscamos contribuir para o aprofundamento da pesquisa acadêmica brasileira sobre a relação entre gênero e saúde e segurança no trabalho, bem como desconstruir preconceitos e apresentar algumas propostas para que as normas do Direito do Trabalho superem paradigmas sexistas e possam evoluir no sentido da promoção da igualdade entre homens e mulheres, essencial para a construção do equilíbrio do meio ambiente de trabalho.

Para que nossa linha de pesquisa possa ser devidamente seguida, inicialmente, no capítulo 1, abordaremos o conceito de meio ambiente do trabalho, demonstrando que a igualdade entre trabalhadores e trabalhadoras é eixo fundamental para que exista equilíbrio labor-ambiental. Em seguida, apresentamos as bases teóricas que explicam as relações de gênero e a opressão das mulheres, o que passa pela construção histórica da diferença entre os sexos e pela compreensão da divisão sexual

\footnotetext{
${ }^{10}$ ADDATI, Laura; CASSIRER, Naomi; GILCHRIST, Katherine. Maternity and paternity at work: law and practice across the world. Genebra: OIT, 2014. p. 96.

${ }^{11}$ VIANA, Márcio Túlio. Os dois modos de discriminar e o futuro do direito do trabalho. In: VIANA, Márcio Túlio; RENAULT, Luiz Otávio Linhares (coord.). Discriminação. São Paulo: LTr, 2000. p. 321328. p. 328.
} 
do trabalho como base material da relação de poder entre os sexos, o que é possível por meio da conjugação entre teoria feminista e sociologia do trabalho e do gênero.

Formado este suporte histórico e teórico, buscaremos explicar a influência do gênero sobre os riscos ocupacionais por meio da análise das especificidades do trabalho das mulheres na atualidade, expressas na segregação profissional por sexo, nos estereótipos que ainda delimitam o que é "trabalho de homem" e "trabalho de mulher", e que compreendem o trabalho das mulheres como leve e de menor valor, bem como pela predominância dos trabalhos precários entre as mulheres. Utilizar esses conceitos será fundamental para evidenciar como o uso da categoria gênero pode contribuir para os estudos de saúde e segurança no trabalho.

No capítulo 2 trataremos das normas relativas à saúde e segurança no trabalho, traçando, em primeiro momento, o panorama histórico dos meios jurídicos de proteção às mulheres nessa esfera, tanto em âmbito internacional, quanto nacional. Em seguida, chegaremos à atualidade normativa, momento em que elencaremos o direito vigente em relação à proteção do trabalho sadio e seguro das mulheres. A junção do panorama histórico e do estado da técnica permitirá constatar o olhar biologicista e sexista do Direito em relação ao trabalho das mulheres, bem como externar a falsa neutralidade existente hoje nos conceitos em saúde e segurança no trabalho.

Finalizada esta etapa da pesquisa, partiremos para o estudo focado das áreas do trabalho em que as diferenças entre mulheres e homens fazem-se mais perceptíveis ou pungem maior atenção em relação à elaboração normativa voltada para a proteção das trabalhadoras, o que só pode ser feito com o auxílio de teorias e abordagens de diferentes áreas do conhecimento, como a Sociologia, a Medicina, a Biologia, a Psiquiatria e a Saúde Pública, a fim de demonstrar que o Direito, o trabalho e a saúde têm dois sexos. ${ }^{12}$

Desse modo, o capítulo 3 aborda as questões que envolvem a proteção da maternidade no trabalho, sempre sob a perspectiva de gênero. Buscamos evidenciar, já no início, as cargas que os papéis de gênero imputam sobre as mulheres em relação à maternidade, demonstrando como a construção social da maternidade cria sentimento de culpa nas mulheres, uma vez que a sociedade não lhes dá escolhas a não ser optar entre

\footnotetext{
${ }^{12}$ Referência à expressão cunhada por Eleonora Menicucci de Oliveira, "trabalho e a saúde têm dois sexos", que por sua vez, toma por base o termo "a classe operária tem dois sexos", de Elizabeth SouzaLobo.
} 
ser mãe ou dar continuidade à sua carreira profissional, sendo a tentativa de conciliação entre trabalho e família motivo de grande desgaste e sofrimento.

Partindo dessa compreensão, estudaremos a legislação brasileira de proteção específica das trabalhadoras mães. Primeiramente, demonstramos como os atuais formatos de licença à gestante, licença-paternidade e salário-maternidade reforçam a divisão sexual do trabalho, uma vez que impõem quase que exclusivamente às mulheres o dever de cuidado do filho ou filha em seus primeiros meses de vida. Depois disso, voltamos nossa atenção às normas que deveriam proteger a saúde e segurança das mães no trabalho, tanto no período da gestação, quanto no aleitamento, verificando as falhas e ausências.

Diante, então, das deficiências constatadas na legislação, propomos algumas alternativas que possibilitam combinar a proteção da reprodução social a uma maior igualdade entre trabalhadores e trabalhadoras com responsabilidades domésticas, que são a licença parental, direito que permite mães e pais compartilharem a atenção às crianças recém-nascidas, e a efetivação do direito à creche, meio de socialização do trabalho doméstico que diminui a sobrecarga de trabalho familiar das mulheres.

O capítulo 4 destina-se à investigação das relações entre ergonomia e os corpos das mulheres em face dos riscos ocupacionais, cuja base é a desconstrução do estereótipo de fragilidade das mulheres, que permite a crítica à normativa que distingue os limites de carga que homens e mulheres podem suportar no trabalho e ao dispositivo que diferencia a capacidade de trabalhadoras e trabalhadores cumprirem horas extras pela imposição de um intervalo pré-jornada extraordinária às mulheres, mas não aos homens.

Em termos ergonômicos, abordaremos a inadequação do maquinário e dos equipamentos de proteção para as trabalhadoras, por serem moldados sobre padrões masculinos de trabalhadores, bem como a maior incidência das LER/DORT sobre as mulheres trabalhadoras, o que se deve não a uma maior sensibilidade ao adoecimento, mas devido à organização do trabalho e à segregação de grande parte das mulheres em profissões monótonas, que exigem gestos repetitivos e atenção redobrada. O último tópico, assim, é dedicado à necessidade de a legislação adotar o paradigma da variabilidade humana individual, como um meio de proteger, sem discriminar.

Por fim, o capítulo 5 trata da saúde mental das mulheres no trabalho, o que exige a desconstrução da imagem sexista de instabilidade feminina, feita no primeiro tópico. Posteriormente, abordamos de forma breve a relação entre os transtornos 
mentais e o gênero, que explica a prevalência de determinadas doenças mentais em mulheres ou homens. Mais adiante, buscamos analisar o sofrimento das mulheres no trabalho, por duas vertentes complementares: o papel social exercido pelas mulheres, com enfoque nas dificuldades de compatibilizar profissão e responsabilidades familiares; e a violência psicológica, assédio moral e sexual, aos quais as mulheres estão mais expostas no ambiente de trabalho.

Antes disso, porém, é preciso que façamos alguns esclarecimentos metodológicos referentes à redação desta dissertação. Em primeiro lugar, optamos por utilizar o termo "saúde e segurança no trabalho" por se tratar da expressão atualmente consagrada para a temática da proteção à integridade física e psíquica do ser humano no meio ambiente de trabalho, adotada pela OIT na Convenção n. $155^{13}$ e em seus demais documentos, e oficialmente utilizada pelo Brasil desde o Decreto $\mathrm{n}^{\mathrm{o}}$. 7.602, de 2011, que instituiu a Política Nacional de Segurança e Saúde no Trabalho. Por conseguinte, deixamos de lado os termos "segurança e medicina do trabalho", da CLT, ${ }^{14}$ e "saúde, higiene e segurança", da $\mathrm{CF},{ }^{15}$ por serem controversos na literatura médica ocupacional.

A fim de delimitar nosso campo de estudo, elucidamos também que o sujeito principal desta pesquisa são as mulheres trabalhadoras economicamente dependentes, uma vez que entendemos que o Direito do Trabalho deve tutelar os hipossuficientes na relação capital-trabalho, que não se encontram mais apenas dentro das relações de emprego, mas, predominantemente, em formas menos protegidas de trabalho. ${ }^{16}$ Dessa forma, não serão consideradas outras formas de dispêndio de trabalho que não as que se incluam neste conceito, no qual se inserem as trabalhadoras empregadas, avulsas, eventuais, urbanas e rurais, domésticas, autônomas e informais.

Ademais, tanto no título do trabalho quanto ao longo da dissertação, lançamos mão da utilização sistemática de "mulheres", com ênfase neste plural, uma

\footnotetext{
${ }^{13}$ OIT. Convenção n. 155 - Saúde e Segurança dos trabalhadores. Adotada em 1981. Ratificada pelo Brasil em 18/05/1992.

${ }^{14}$ BRASIL. CLT. Capítulo V do Título II: "Da Segurança e da Medicina do Trabalho".

${ }^{15}$ BRASIL. $C F$. Art. $7^{\circ}$. São direitos dos trabalhadores urbanos e rurais, além de outros que visem à melhoria de sua condição social: XXII. redução dos riscos inerentes ao trabalho, por meio de normas de saúde, higiene e segurança.

${ }^{16}$ Tomamos como base a noção de Murilo Carvalho Sampaio de Oliveira: "A ontologia juslaboral não se esvai ante o mundo em transição pós-moderna e a fábrica pós-fordista. A condição do trabalhador, não mais do empregado, persiste no contexto da dependência ou hipossuficiência. Há que se vislumbrar de maneira indissociável o binômio hipossuficiência-dependência, que implica a defesa de um Direito do Trabalho de cunho protetivo enquanto seus destinatários perdurarem numa situação de desigualdade econômica". In: OLIVEIRA, Murilo Carvalho Sampaio. Direito do Trabalho e Emancipação. Revista da Faculdade de Direito da UFPR [online], vol. 46, n. 0, 2007.
} 
vez que "as mulheres são muito diversas nas suas condições de exercício da cidadania". ${ }^{17}$ Compreendemos que a linguagem deve externar a existência de diversos fatores que interferem e diferenciam as experiências de vida de cada mulher, como raça, classe, religião, origem, sexualidade etc., de modo a reconhecer que não existe "a mulher" padronizada ou genérica, pois o singular e as categorizações universais "sempre são excludentes, legitimando os já legitimados e colocando à margem aqueles(as) que não se ‘enquadram' em suas referências". ${ }^{18}$

\footnotetext{
${ }^{17}$ SOARES, Vera. Políticas Públicas para igualdade: o papel do Estado e diretrizes. In: GODINHO, Tatau; SILVEIRA, Maria Lucia da. Políticas Públicas e Igualdade de Gênero. São Paulo: Coordenadoria Especial da Mulher da Prefeitura de São Paulo, 2004. p. 113-126.

${ }^{18}$ LOURO, Guacira Lopes. Nas redes do conceito de gênero. In: LOPES, Marta Julia Marques; MEYER, Dagmar Estermann; WALDOW, Vera Regina. Gênero \& Saúde. Porto Alegre: Artes Médicas, 1996. p. 718. p. 15.
} 


\section{Capítulo 1. A perspectiva de gênero no ambiente do trabalho}

\subsection{A igualdade entre os sexos como eixo para o meio ambiente equilibrado}

O equilíbrio labor-ambiental possui íntima relação com a qualidade de vida dos seres humanos, motivo pelo qual sua proteção centra-se na prevenção de fatores que podem gerar efeitos deletérios ao indivíduo, especificamente na proteção contra doenças e acidentes relacionados ao trabalho. Garantido pelo artigo 225, caput da $\mathrm{CF}$, meio ambiente do trabalho pode ser entendido, nas palavras de José Afonso da Silva, como "local em que se desenrola boa parte da vida do trabalhador, cuja qualidade de vida está, por isso, em íntima dependência da qualidade daquele ambiente". ${ }^{19}$

Em sua definição, meio ambiente do trabalho é o lugar onde se realiza a atividade laboral, independente se em estabelecimento do empregador ou outra localidade, com elementos físicos, químicos e biológicos presentes naquele espaço, somados ao processo produtivo e à organização do trabalho, bem como ao complexo de relações humanas ali desenvolvidas. ${ }^{20}$ Por conseguinte, não se limita ao ambiente interno da empresa, mas compreende também "as circunstâncias em seu derredor que sejam afetadas com as condições materiais ou psicológicas em que o labor é executado". ${ }^{21}$

Segundo Júlio César de Sá da Rocha, o meio ambiente do trabalho não se restringe ao espaço interno da fábrica ou empresa, mas mais do que isso, representa "todos os elementos, inter-relações e condições que influenciam o trabalhador em sua saúde física e mental, comportamento e valores reunidos no locus do trabalho". Dessa forma, a saúde é resultado da interação dos diversos elementos que compõem o ambiente, que podem provocar tanto bem-estar quanto mal-estar no trabalho. ${ }^{22}$

Nesse sentido, para Raimundo Simão de Melo, o meio ambiente laboral "deve levar em conta a pessoa do trabalhador e tudo que o cerca", pois abrange "o local de trabalho, os instrumentos de trabalho, o modo de execução das tarefas e a maneira

\footnotetext{
${ }^{19}$ SILVA, José Afonso da. Direito Ambiental Constitucional. 2 ed. São Paulo: Malheiros, 1995. p. 5.

${ }^{20}$ MORAES, Monica Maria Lauzid de. O direito à saúde e segurança no meio ambiente do trabalho: proteção, fiscalização e efetividade normativa. São Paulo: LTr, 2002. p. 27.

${ }^{21}$ BRANDÃO, Cláudio. Meio ambiente do trabalho saudável: direito fundamental do trabalhador. Revista do Tribunal Regional do Trabalho da $1^{a}$ Região, v. 21, n. 49, p. 89-98, jan./jun. 2011. p. 92.

${ }^{22}$ ROCHA, Julio Cesar de Sá da. Direito ambiental do trabalho. São Paulo: LTr, 2002. p. 127-128.
} 
como o trabalhador é tratado pelo empregador ou tomador de serviço e pelos próprios colegas de trabalho". ${ }^{23}$ Assim, é resultado de uma complexa combinação de fatores como progresso tecnológico, equipamentos industriais, processos e modos de organização do trabalho que podem gerar reflexos na vida do obreiro ou da obreira. ${ }^{24}$

Desse modo, a noção de meio ambiente do trabalho equilibrado concretiza a percepção de que as condições laborais e a existência de um local de trabalho sadio, em termos físicos e psicológicos, são fatores que influenciam decisivamente o bem-estar e a qualidade de vida de homens e mulheres que trabalham. Assim, a proteção labor-ambiental por meio da tutela da saúde e segurança no trabalho é central para a dignidade da pessoa humana, pois tem reflexos em todas as esferas da vida.

Guilherme Guimarães Feliciano, ao analisar documentos e declarações internacionais que, mesmo não pertencendo ao Direito ambiental ou trabalhista, abordaram o descaso do sistema capitalista com a natureza e a saúde de trabalhadoras e trabalhadores, afirma que existe uma indissociabilidade ontológica entre o meio ambiente natural e o meio ambiente humano. Para o autor, o meio ambiente, tanto o conceito quanto a entidade,

(...) apreende-se como "gestalt", ali em acepção filosófica (significando que a interpretação do objeto modifica ou condiciona a própria experiência com o objeto) e aqui em acepção fenomênica (o meio ambiente não deve ser tomado como soma de elementos a isolar, analisar e dissecar, mas como sistema constituído por "unidades autônomas, manifestando uma solidariedade interna e possuindo leis próprias, donde resulta que o modo de ser de cada elemento depende da estrutura do conjunto e das leis que o regem, não podendo nenhum dos elementos preexistir ao conjunto"). ${ }^{25}$

Partindo dessa compreensão sistêmica do meio-ambiente do trabalho, é possível compreender que seu equilíbrio pressupõe a união de diversos fatores relacionados não só à estrutura e à organização do trabalho, mas também às relações interpessoais que se dão tanto dentro como fora do local da prestação do serviço. Nesse

\footnotetext{
${ }^{23}$ MELO, Raimundo Simão de. Direito ambiental do trabalho e a saúde do trabalhador. 5. ed. São Paulo: LTr, 2013. p. 29.

${ }^{24}$ ROSHCHIN, A. V. Protection of the Working Environment. International Labour Review, v. 110, n. 3 , p. 235-249, 1974. Disponível em <http://heinonline.org/HOL/LandingPage? handle=hein.journals /intlr110\&div=30\&id=\&page=>. Acesso em: 2.jul.2014. p. 235.

${ }^{25}$ FELICIANO, Guilherme Guimarães. Meio ambiente do trabalho (aspectos gerais e propedêuticos). Revista do Tribunal Regional do Trabalho da $15^{a}$ Região, [online], v. 20, p. 1-49, 2002. Disponível em <http://portal.trt15.jus.br/documents/124965/125414/Rev20Art12.pdf/c44e2910-96d2-4d0a-9cc51c8e64720c2e>. Acesso em: 24.jun.2014. p. 3.
} 
sentido, pressupõe-se o igual tratamento e a livre manifestação de todos e todas, de maneira que a existência de discriminação de qualquer tipo gera transtornos no ambiente e mal-estar para trabalhadores e trabalhadoras. A centralidade da igualdade para o equilíbrio ambiental foi reconhecida na Declaração de Estocolmo sobre o Ambiente Humano, de 1972, ao declarar como Princípio 1 o direito fundamental do ser humano

(...) à liberdade, à igualdade e ao desfrute de condições de vida adequadas em um meio ambiente de qualidade tal que lhe permita levar uma vida digna e gozar de bem-estar, tendo a solene obrigação de proteger e melhorar o meio ambiente para as gerações presentes e futuras. A este respeito, as políticas que promovem ou perpetuam o apartheid, a segregação racial, a discriminação, a opressão colonial e outras formas de opressão e de dominação estrangeira são condenadas e devem ser eliminadas. ${ }^{26}$

Considerando que a divisão dos seres humanos em dois sexos, enquanto parte integrante da identidade individual e princípio organizador da sociedade, reflete-se no trabalho e que o trabalho é central na construção da identidade do ser humano, por ser "um processo de construção e de reconhecimento de si", ${ }^{27}$ a importância estratégica das políticas de igualdade precisa ser repensada para que passem a abordar "uma perspectiva de transformação das instituições e das estruturas produtoras das hierarquias de sexo", abarcando a esfera laboral, mas não se limitando a ela. ${ }^{28}$

Assim, nosso ponto de partida é pensar o meio ambiente laboral sadio a partir da recusa do "entendimento do trabalho enquanto prática assexuada devido à variabilidade da organização técnica e social com base no sexo". ${ }^{29}$ Em termos de adoecimento no trabalho, isso significa levar em conta que os riscos laborais aos quais as mulheres estão expostas muitas vezes são diferentes daqueles que afligem os homens

\footnotetext{
${ }^{26}$ ORGANIZAÇÃO DAS NAÇÕES UNIDAS - ONU. Declaração da Conferência das Nações Unidas sobre o Meio Ambiente Humano. Estocolmo: ONU, 1972. Disponível em: $<$ http://www.direitoshumanos.usp.br/index.php/Meio-Ambiente/declaracao-de-estocolmo-sobre-oambiente-humano.html>. Acesso em: 24.jun.2014.

${ }^{27}$ DUBAR, Claude. A construção de si pela atividade de trabalho: a socialização profissional. Cadernos de Pesquisa, São Paulo, v. 42, n. 146, p. 351-367, mai./ago.2012. p. 351.

${ }^{28}$ VARIKAS, Eleni. Igualdade. In: HIRATA, Helena; LABORIE, Françoise; LE DOARÉ, Hélène; SENOTIER, Danièle (org.). Dicionário Crítico do Feminismo. São Paulo: Editora Unesp, 2009. p. 116122.

${ }^{29}$ BRITO, Jussara Cruz de; NEVES, Mary Yale; OLIVEIRA, Simone Santos; ROTENBERG, Lucia. Saúde, subjetividade e trabalho: o enfoque clínico e de gênero. Revista Brasileira de Saúde Ocupacional, São Paulo, v. 37, n. 126, p. 316-329, 2012. p. 320.
} 
e, consequentemente, os danos à saúde também serão. ${ }^{30}$ Essa compreensão demanda que tracemos novas estratégias de prevenção e que repensemos o modo como o Direito do Trabalho protege trabalhadores e trabalhadoras. ${ }^{31}$

À tal demanda soma-se a percepção de que o Direito do Trabalho passa por uma mudança de paradigma em relação ao tratamento das trabalhadoras: a sociedade precisa superar a ideia de necessidade de tutela das mulheres, o que parte de premissas já discriminatórias, pois considera as mulheres em situação de inferioridade e supõe a necessidade de salvá-las, e partir para a promoção da igualdade, de modo que o verbo "proteger" passe a significar, para o Direito do Trabalho, "promover $o$ proporcionar condiciones para el ejercicio de la igualdad". ${ }^{32}$

\subsection{A construção social dos sexos}

Se a desigualdade entre os sexos é obstáculo para o equilíbrio laborambiental, parece simples afirmar que basta aplicarmos os preceitos legais de igualdade para que o equilíbrio seja restaurado. Entretanto, a construção social da desigualdade possui origens e estruturas que precisam ser compreendidas para que todas as facetas da discriminação sejam percebidas e descontruídas, caso contrário poderemos ter avanços superficiais nas condições de vida das mulheres (e homens) trabalhadoras, mas ainda assim sobre as bases da exclusão.

Para isso, passaremos agora às bases teóricas do presente trabalho. Buscaremos elucidar a questão das relações de gênero e da construção social dos sexos, para que seja possível compreender como as estruturas de dominação estão presentes

\footnotetext{
${ }^{30}$ Tais danos à saúde são denominados pela OIT (2013, p. 4) como "doenças profissionais", em sentido amplo, definidas como aquelas "contraídas em resultado de uma exposição a fatores de risco subjacentes a uma atividade profissional", origem profissional que é reconhecida pelo estabelecimento de uma "relação causal entre a doença e a exposição do trabalhador a determinados agentes perigosos no local de trabalho". Vale dizer, porém, que a doutrina brasileira distingue doença profissional de doença do trabalho: a primeira seria alteração fisiopsicológica provocada ou inerente a certas atividades profissionais, "existindo sempre uma relação indiscutível entre a causa e o efeito", como é o caso da silicose e das intoxicações por produtos utilizados no trabalho; já a segunda "seria aquela afecção que nem sempre estaria rigorosamente relacionada com o trabalho e provocada por este", caso em que é preciso comprovar a relação entre causa e efeito, como o aparecimento de varizes pelo trabalho em pé (MARANO, Vicente Pedro. Doenças ocupacionais. São Paulo: LTr, 2003, p. 33-34).

${ }^{31}$ INSTITUTO NAVARRO DE SALUD LABORAL. Ficha técnica de prevención 35 - Mujeres y Salud Laboral: Prevención de riesgos laborales desde la perspectiva de género. Navarra: Gobierno de Navarra, 2011. p. 2.

${ }^{32}$ ERMIDA URIARTE, Oscar. La mujer en el derecho del trabajo: de la protección a la promoción de la igualdad. In: PENIDO, Laís de Oliveira (coord.). Igualdade dos gêneros nas relações de trabalho. Brasília: ESMPU, 2006. p. 115-126. p. 116-118.
} 
em todos os espaços da vida, enraizando-se a ponto de parecerem naturais. Isso nos permitirá, adiante, perceber como essa construção também interfere nas ciências, especialmente as médicas, que, posteriormente reproduzidas pelo Direito, acabam por reforçar preconceitos ao invés de contribuir para a igualdade.

\subsubsection{A concepção da diferença sexual}

Ao longo do século XX, na tentativa de desnaturalizar a desigualdade entre os sexos, a teoria feminista voltou parte de sua atenção ao questionamento "diferença sexual", para demonstrar que, mais do que um fato natural, ela é uma justificativa ontológica para tratar homens e mulheres de modo diferenciado tanto no campo político quanto social. ${ }^{33}$ Buscava-se, assim, demonstrar que o "sexo não é simplesmente um fato pré-social". 34

O primeiro passo nessa direção foi recusar o sexo como um fato natural e, por conseguinte, negar que a sexualidade, os corpos, os órgãos reprodutivos e a maternidade sejam realidades estritamente biológicas. Ademais, buscou-se enfatizar que a própria biologia é uma categoria sociocultural. ${ }^{35}$ Este caminho foi percorrido por estudiosos com diferentes abordagens teóricas, as quais, cada uma a seu modo, auxiliam a compreensão da evolução histórica dessas categorias. Por conta disso, tais enfoques teóricos não se excluem, pelo contrário, podem ser complementares, ${ }^{36}$ motivo pelo qual abordaremos alguns deles para melhor respaldar nosso argumento.

Segundo Pierre Bourdieu, ${ }^{37}$ o corpo é socialmente construído como realidade sexuada, de modo que a diferença biológica entre os corpos masculinos e

\footnotetext{
${ }^{33}$ MELO, Érica. Feminismo: velhos e novos dilemas uma contribuição de Joan Scott. Cadernos Pagu, Campinas, n. 31, p. 553-564, 2008. p. 555.

${ }^{34}$ MOORE, Henrietta. Understanding Sex and gender. In INGOLD, Tim (org.). Companion Encyclopedia of Antropology. London: Routledge, 1997. (Tradução de Júlio Assis Simões para uso didático). p.4.

${ }^{35}$ BOCK, Gisela. História, história das mulheres, história do género. Penélope: Revista de História e Ciências Sociais [online], n. 4, p. 147-178, 1990. p. 166-167.

${ }^{36}$ PETERSEN, Áurea T. Discutindo o uso da categoria gênero e as teorias que respaldam estudos de gênero. In: STREY, Marlene Neves (org.) et al. Gênero por Escrito: saúde, identidade e trabalho. Porto Alegre: EDIPUCRS, 1999. p. 15-39. p. 35-37.

${ }^{37}$ A teoria de Pierre Bourdieu funda-se na ideia de violência simbólica: dominação masculina se afirma na objetividade das estruturas sociais e da divisão sexual do trabalho e nos esquemas imanentes a todos os habitus, de modo que eles funcionam como matrizes do pensamento e ação de todos os membros da sociedade, impondo-se como transcendentes. Consequentemente, as próprias mulheres aplicam à realidade esses esquemas de pensamento que derivam da dominação masculina (BOURDIEU, 2014, p. 54). Para o autor, as disposições (habitus) são inseparáveis das estruturas, que as produzem e reproduzem, tanto nos homens como nas mulheres, disposições que encontram seu fundamento na estrutura do
} 
femininos e a diferença anatômica entre órgãos sexuais são utilizadas como justificativa da diferença socialmente construída entre os gêneros. Assim, definição social dos órgãos sexuais não é apenas o registro de suas propriedades naturais, mas produto de escolhas orientadas a acentuar certas diferenças e obscurecer certas semelhanças. Para o autor, "as diferenças visíveis entre os órgãos sexuais masculino e feminino são uma construção social que encontra seu princípio nos princípios de divisão da razão androcêntrica". ${ }^{38}$ Por conseguinte,

(...) longe de as necessidades da reprodução biológica determinarem a organização simbólica da divisão sexual do trabalho e, progressivamente, de toda a ordem natural e sexual, é uma construção arbitrária do biológico, e particularmente do corpo, masculino e feminino, de seus usos e de suas funções sobretudo na reprodução biológica, que dá um fundamento aparentemente natural à visão androcêntrica da divisão de trabalho sexual e da divisão sexual do trabalho e, a partir daí, de todo o cosmos. A força particular da sociodiceia masculina lhe vem do fato de ela acumular e condensar duas operações: ela legitima uma relação de dominação inscrevendoa em uma natureza biológica que é, por sua vez, ela própria, uma construção social naturalizada. ${ }^{39}$

Ponto importante desta teoria é a ideia de somatização das relações de dominação, ou seja, de que a socialização difusa e contínua das identidades de "homem" e "mulher" faz com que elas sejam de fato incorporadas aos corpos das pessoas. ${ }^{40}$ Pierre Bourdieu afirma que, por meio da educação social, as construções sociais são inscritas nos corpos (embodied), permitindo que a dominação simbólica funcione, pois para isso é preciso que "os dominados tenham incorporado as estruturas segundo as quais os dominantes os percebem, que a submissão não seja um ato da consciência, suscetível de ser compreendido". ${ }^{41}$

Nesse sentido, Cordelia Fine sustenta que não existe nítida linha de separação entre o eu e a cultura, uma vez que esta possui profunda relação com nossa

mercado de bens simbólicos. O princípio da exclusão das mulheres não é mais que a dissimetria fundamental, do sujeito versus objeto, instaurada entre o homem e a mulher no terreno das trocas simbólicas, das relações de produção e reprodução do capital simbólico (Ibid., p. 66). Desse modo, “a ordem social funciona como uma imensa máquina simbólica que tende a ratificar a dominação masculina sobre a qual se alicerça”, o que se dá por meio da divisão sexual do trabalho e das estruturas de espaço e tempo (Ibid., p. 23-24).

${ }^{38}$ BOURDIEU, Pierre. A dominação masculina. Rio de Janeiro: Best Bolso, 2014. p. 23-30.

${ }^{39}$ Ibid., p. 39-40.

${ }^{40}$ Ibid., p. 41.

${ }^{41}$ Id., Novas reflexões sobre a dominação masculina. In: LOPES, Marta Julia Marques; MEYER, Dagmar Estermann; WALDOW, Vera Regina. Gênero \& Saúde. Porto Alegre: Artes Médicas, 1996. p. 28-40. p. 35-36. 
mente. Por conta disso, a compreensão das diferenças de gênero na mente feminina e masculina só é possível se entendermos que o crânio, que separa a mente do contexto sociocultural, é psicologicamente permeável, não servindo de barreira para possíveis efeitos psicologicamente debilitantes ou estimulantes decorrentes de crenças culturais. Assim, se há no ambiente o gênero proeminente, passamos a pensar em nós mesmos a partir de seus estereótipos, o que pode modificar nossa autopercepção e alterar nossos interesses de acordo com as expectativas sociais. ${ }^{42}$

De acordo com a autora, a desigualdade de gênero é tanto parte de nossa mente quanto de nossa biologia, porque não existem setas unidirecionais que saem dos genes para os hormônios, destes para o cérebro e, então, para o ambiente. Ao contrário,

(...) os circuitos do cérebro são bastante literalmente um produto do seu ambiente físico, social e cultural, bem como do seu comportamento e pensamentos. Aquilo que experimentamos e fazemos cria a atividade neural que pode alterar o cérebro, quer diretamente, quer por meio de mudanças na expressão dos genes. Essa neuroplasticidade significa que (...) o fenômeno social do gênero "entra no cérebro" e "se torna parte da nossa biologia cerebral". ${ }^{3}$

$\mathrm{Na}$ análise de Michel Foucault sobre a história da sexualidade, foi a partir do século XIX que se elaborou a ideia de que existiria algo além dos corpos, órgãos e sistemas anatômico-fisiológicos, ou seja, o "sexo", com propriedades intrínsecas e leis próprias. ${ }^{44}$ A noção de sexo permitiu criar uma unidade artificial entre elementos anatômicos, funções biológicas, condutas e sensações, fazendo com que essa unidade funcionasse como "princípio causal, sentido onipresente, segredo a descobrir em toda parte", ou seja, o sexo pôde funcionar como "significante único e como significado universal”. Segundo o autor,

a noção de sexo garantiu uma reversão essencial: permitiu inverter a representação das relações de poder e a sexualidade, fazendo-a parecer não na sua relação essencial e positiva com o poder, porém como ancorada em uma instância específica e irredutível que o poder tenta da melhor maneira sujeitar; assim, a ideia "do sexo" permite esquivar o que constitui o "poder" do poder; permite pensá-lo apenas como lei e interdição. O sexo, essa instância que parece dominar-nos, esse segredo que nos parece subjacente a tudo o que somos, esse ponto que nos fascina pelo poder que manifesta e pelo sentido que oculta, ao qual pedimos revelar o que somos e libertar o que nos define, o sexo

\footnotetext{
${ }^{42}$ FINE, Cordelia. Homens não são de Marte, mulheres não são de Vênus: como a nossa mente, a sociedade e o neurossexismo criam a diferença entre os sexos. São Paulo: Cultrix, 2012. p. 21.

${ }^{43}$ Ibid., p. 295.

${ }^{44}$ FOUCAULT, Michel. História da sexualidade I: A vontade de saber. Rio de Janeiro: Edições Graal, 1988. p. 143.
} 
nada mais é do que um ponto ideal tornado necessário pelo dispositivo de sexualidade e por seu funcionamento. ${ }^{45}$

$\mathrm{O}$ argumento de Michel Foucault é de que o sexo é produto de práticas discursivas específicas, ponto pelo qual todos devem passar para chegarem à sua inteligibilidade, à totalidade de seu corpo e à sua identidade, repreendendo que não se deve situar o sexo como algo real e concreto, ou "natural", e a sexualidade como algo abstrato e ilusório, pelo contrário: ele afirma que a sexualidade é uma figura histórica muito real, responsável por suscitar a noção de sexo, pois serve a ele como elemento especulativo necessário a seu funcionamento. ${ }^{46}$

Anne Fausto-Sterling, baseada na teoria foucaultiana, pontua que nossas experiências corporais são fruto de nosso desenvolvimento em culturas e períodos históricos específicos. Em outras palavras, na medida em que os seres humanos crescem e se desenvolvem, eles também constroem seus corpos, discursiva e literalmente, incorporando experiências em sua própria carne. O sexo, assim, é "um fato somático criado por um efeito cultural". 47

Para ilustrar seu raciocínio, a autora relata o episódio emblemático de Maria Patiño, integrante da equipe espanhola de corrida com barreiras para as Olimpíadas de 1988, que ao se submeter ao exame para "controle da feminilidade" exigido pelo Comitê Olímpico Internacional, feito por meio de raspagem de células da bochecha, foi informada que não poderia competir, pois suas células continham o cromossomo Y. Maria Patiño, depois de ter sido expulsa da equipe e hostilizada em toda a mídia espanhola, decidiu contestar a decisão do comitê. Para isso, submeteu-se a exames em que médicos "analisaram suas estruturas pélvicas e ombros" de modo a decidir "se ela era suficientemente feminina para competir". Dois anos depois, Maria Patiño foi readmitida na equipe olímpica da Espanha. ${ }^{48}$

Ao questionar o porquê de o Comitê Olímpico Internacional se ocupar tanto em definir e comprovar o sexo de competidores, a autora menciona ainda o único caso em que um homem, da Juventude Nazista, infiltrou-se na competição feminina de

\footnotetext{
${ }^{45}$ FOUCAULT, Michel. História da sexualidade I: A vontade de saber. Rio de Janeiro: Edições Graal, 1988. p. 144-145.

${ }^{46}$ Ibid., p. 147.

${ }^{47}$ FAUSTO-STERLING, Anne. Dualismos em duelo. Cadernos Pagu, Campinas, n. 17-18, p. 7-79, 2002. p. 59-60.

${ }^{48}$ Ibid., p. 11-13.
} 
salto em altura, em 1936. Tanto a masculinidade não representou grandes vantagens que ele ficou em quarto lugar, atrás de três mulheres. ${ }^{49}$ A autora, então, reforça que

(...) o sexo de um corpo é simplesmente complexo demais. Não existe o isso ou aquilo. (...) rotular alguém homem ou mulher é uma decisão social. Podemos utilizar o conhecimento científico para nos ajudar a tomar a decisão, mas só nossas crenças sobre o gênero - e não a ciência - podem definir nosso sexo. Além disso, nossas crenças sobre o gênero também afetam o tipo de conhecimento que os cientistas produzem sobre o sexo. (...) Nossos corpos são complexos demais para dar respostas claras sobre a diferença sexual. Quanto mais procuramos uma base física simples para o 'sexo' mais claro fica que o 'sexo' não é uma categoria física pura. Aqueles sinais e funções corporais que definimos como masculinos e femininos já vêm misturados em nossas ideias sobre o gênero. ${ }^{50}$

A metáfora da matryoshka, a boneca russa composta por uma série de bonecas que são colocadas umas dentro das outras, é usada por Anne Fausto-Sterling para demonstrar de modo mais claro o processo de mão-dupla que conecta a produção do conhecimento sobre o corpo influenciado pelo gênero, de um lado, à materialização do gênero dentro do corpo, de outro. As bonecas do conjunto representam as várias camadas da sexualidade humana, que podem academicamente ser estudadas de modo separado, mas estarão ocas, pois apenas juntas fazem sentido. ${ }^{51}$ Segundo a autora,

(...) using Russian nesting dolls as a framework suggests that history, culture, relationships, psyche, organism, and cell are each appropriate locations from which to study the formation and meanings of sexuality and gender. Developmental systems theory, whether applied to the assembled doll or to its subunits, provides the scaffolding for thought and experiment. Assembling the smaller dolls into a single large one requires the integration of knowledge derived from very different levels of biological and social organization. The cell, the individual, groups of individuals organized in families, peer groups, cultures, and nations and their histories all provide sources of knowledge about human sexuality. We cannot understand it well unless we consider all of these components. ${ }^{52}$

Exemplo de como o conhecimento científico sobre o sexo é permeado por todas essas esferas, especialmente pela cultura e expectativas sociais, é a defesa feita pelos médicos do século XIX da exclusão feminina da educação formal, com o

\footnotetext{
${ }^{49}$ FAUSTO-STERLING, Anne. Dualismos em duelo. Cadernos Pagu, Campinas, n. 17-18, p. 7-79, 2002. p. 13.

${ }^{50}$ Ibid., p. 15-19.

${ }^{51}$ Id., Sexing the body: Gender politics and the construction of sexuality. New York: Basic Books, 2000. p. 253-254.

${ }^{52}$ Ibid., p. 254-255.
} 
argumento de que as mulheres não poderiam se desgastar nos estudos, especialmente no período da puberdade, porque sua energia deveria estar voltada exclusivamente para o desenvolvimento e atividade dos órgãos reprodutivos, não podendo ser desperdiçada com o desenvolvimento do cérebro. Feministas da época já combatiam tal discurso médico, alegando que os homens também passam por transformações na puberdade, mas isso não era motivo para afastar os meninos dos estudos. ${ }^{53}$

A reconstrução histórica do processo de evolução do conhecimento científico sobre as diferenças sexuais, feita por Fabíola Rohden, demonstra que, enquanto no século XVIII a ideia predominante era de que cada pessoa carregava elementos masculinos e femininos, que lutavam no interior da mente na busca pela preponderância, no século XIX a ciência divide psicologicamente os sexos, tornando cada vez mais rígida a separação da razão para os homens e da emoção para as mulheres, a ponto de surgirem questionamentos sobre a existência de razão no cérebro feminino. ${ }^{54}$ Os cientistas acreditavam que a natureza era hierárquica em sua essência, de modo que a diversidade humana justificaria as demais distinções sociais. Com base nessa concepção,

(...) elabora-se um esquema no qual o homem branco, civilizado, europeu representaria a maturidade evolutiva em contraste com a mulher, o primitivo, o não europeu. A própria natureza já definia as escalas e os valores. Os cientistas apenas serviam como intérpretes de suas determinações. A junção desse tipo de perspectiva teórica com a visão de mundo de homens educados em um ambiente de privilégio e autoridade masculina e forte distinção entre as esferas pública e privada e entre as funções sociais de homens e mulheres é que estaria na raiz da produção de conhecimento sobre a mulher e a diferença sexual no século XIX. ${ }^{55}$

Nota-se que, desde aquela época, o trabalho científico apresenta "uma necessidade premente de demonstrar e comprovar a existência de marcos naturais intransponíveis que assegurariam uma distinção radical entre os gêneros", o que se traduz por meio de características vinculadas ao sexo biológico, utilizando no primeiro momento elementos de anatomia básica, até chegar a teorias mais complexas sobre hormônios, neurônios ou genes. No entanto, observa-se que, ao longo do tempo, a busca

\footnotetext{
${ }^{53}$ ROHDEN, Fabíola. Uma ciência da diferença: sexo e gênero na medicina da mulher. Rio de Janeiro: Editora FIOCRUZ, 2001. p. 91.

${ }^{54}$ Id., A construção da diferença sexual na medicina. Cadernos de Saúde Pública, Rio de Janeiro, n. 19, Sup. 2, p. 201-212, 2003. p. 204.

${ }^{55}$ Id., Uma ciência da diferença: sexo e gênero na medicina da mulher. Rio de Janeiro: Editora FIOCRUZ, 2001.p. 41.
} 
pela "substancialização da diferença" se manteve, o que ilustra o interesse de nossa sociedade em reforçar o dualismo entre natureza e cultura. ${ }^{56}$

Segundo a autora, a construção da concepção da diferença entre os sexos, como entendida hoje, deu-se em um contexto de significativas transformações socioeconômicas do século XIX, dentre as quais a industrialização, a crescente urbanização e a entrada mais efetiva das mulheres no mercado de trabalho, que possibilitaram novas formas de relação entre homens e mulheres. ${ }^{57}$ Esse processo gerou a busca por teorias que pudessem explicar os acontecimentos da época, especialmente na Medicina, pois as mudanças eram entendidas

(...) como uma forte ameaça à forma de relações entre os gêneros em curso naquele momento, redefinir ou mesmo reafirmar as bases da diferença parecia fundamental. É nesse sentido que a Medicina e, em particular, as especialidades dedicadas à mulher e à reprodução, como é o caso da ginecologia, se converte em uma verdadeira "ciência da diferença". O argumento central, que perpassa boa parte dos trabalhos da época e também justifica as intervenções concretas, diz respeito a uma distinção natural, de caráter biológico e pré-determinado entre os sexos. Homens e mulheres seriam naturalmente distintos nas suas características físicas e também nas suas características morais ou psicológicas. Além disso, as qualidades atribuídas a cada um e as suas funções sociais são descritas com o mesmo grau de determinismo que suas funções fisiológicas. O gênero parecia irremediavelmente colado ao sexo a partir de uma única e invariável direção. ${ }^{58}$

A ginecologia, em especial, ganhou forte impulso entre o século XIX e começo do século XX, solidificando-se como “o estudo da mulher". No Brasil, produção médica da época ${ }^{59}$ dava ênfase à diferença entre os sexos, sobretudo por meio do estudo de "desordens" femininas advindas de tentativas de fuga dos papéis prescritos às mulheres. Assim, a recusa da maternidade, o desapego à prole, a demonstração de desejo sexual e a vontade insistente de trabalhar fora do lar eram desvios apresentados como decorrentes do mau funcionamento dos órgãos reprodutivos femininos, cujo tratamento prescrito pelos ginecologistas ia da reclusão em hospitais de alienados ${ }^{60}$, até

\footnotetext{
${ }^{56}$ ROHDEN, Fabíola. Uma ciência da diferença: sexo e gênero na medicina da mulher. Rio de Janeiro: Editora FIOCRUZ, 2001. p. 13.

${ }^{57}$ Ibid., p. 14.

${ }^{58}$ Ibid., p. 14.

59 A pesquisa de Fabíola Rohden analisou teses apresentadas na Faculdade de Medicina do Rio de Janeiro, entre 1830 e 1940, que tratavam especificamente das mulheres e prescreviam supostos desvios comportamentais e as prescrições para a manutenção da "normalidade" feminina.

${ }^{60}$ Durante muitos anos no Brasil, o discurso médico, que tratava como doenças os desvios sociais, gerou verdadeiros horrores. Muitas pessoas, em especial mulheres, foram internadas em instituições
} 
a mutilação genital e a extração dos ovários. Consequentemente, um dos males mais tratados na época foi a histeria, seguido de perturbações como a ninfomania e a masturbação. ${ }^{61}$

A autora cita o trabalho do médico Mauricio Sobrinho, datado de 1911, que afirmava coisas como "o instinto sexual é mais intenso no homem do que na mulher", "o amor é um fato capital na vida de uma mulher" e a mulher "é naturalmente e organicamente monógama" e que o amor "não é para ela mais do que uma face secundária da maternidade”. Constata-se a forte associação das mulheres à maternidade, a qual determinaria toda sua existência, inclusive o "amor de mãe" influenciaria suas características morais: "a mulher ama com todo o seu coração. Para ela o amor é a vida. Para o homem, é o prazer da vida", e é por isso "que a mulher se inclina para a monogamia e o homem, para a poligamia". 6263

Além disso, no século XIX, a concepção da separação entre natureza e cultura era usada como fundamento para o desenvolvimento científico, influenciando as tentativas de definição das diferenças sexuais. Era frequente conceber os homens como representantes da cultura e as mulheres como mais próximas da natureza, devido a uma fisiologia que as prenderia a tarefas de reprodução da espécie. Por conta disso, mulheres que abdicavam do papel de mãe e esposa eram estudadas pelos médicos e definidas como doentes, de forma que distinção entre natureza e cultura e a associação do

psiquiátricas e condenadas a uma vida miserável por conta das "normas sociais", conforme mostra Daniela Arbex, no livro Holocausto Brasileiro: Vida, Genocídio e 60 mil mortes no maior hospício do Brasil. O livro relata que "durante décadas, milhares de pacientes foram internados à força, sem diagnóstico de doença mental, num enorme hospício na cidade de Barbacena, em Minas Gerais. Ali foram torturados, violentados e mortos sem que ninguém se importasse com seu destino. Eram apenas epilépticos, alcoólatras, homossexuais, prostitutas, meninas grávidas pelos patrões, mulheres confinadas pelos maridos, moças que haviam perdido a virgindade antes do casamento". (ARBEX, Daniela. Holocausto Brasileiro: Vida, Genocídio e 60 mil mortes no maior hospício do Brasil. São Paulo: Geração Editorial, 2013. Sinopse disponível em: < http://geracaoeditorial.com.br/blog/holocausto-brasileiro/>..).

${ }^{61}$ ROHDEN, Fabíola. Uma ciência da diferença: sexo e gênero na medicina da mulher. Rio de Janeiro: Editora FIOCRUZ, 2001. p. 21.

${ }^{62}$ Ibid., p. 139.

${ }^{63}$ Interessante perceber que esse tipo de discurso, que vincula mulheres à monogamia por conta do "instinto materno" e os homens à poligamia devido a seus "impulsos sexuais", ainda é bastante presente em nossa cultura. Isso é facilmente visível na mídia, em especial nas publicações voltadas ao público feminino, que constantemente apresentam "novos" argumentos, supostamente científicos, para justificar comportamentos sociais. A título de ilustração, a Revista Nova publicou, em junho de 2012, reportagem sobre "diferenças mentais" de homens e mulheres, na qual se afirmava que "MULHERES pensam em sexo uma vez por dia; HOMENS pensam em sexo a todo momento". Vale citar também matéria do Portal Mulher UOL, de setembro de 2013, cuja manchete autoexplicativa dizia "Estudo: homens traem mais porque têm impulsos sexuais mais fortes". Disponíveis em: <http://mdemulher.abril.com.br/amorsexo/reportagem/ relacionamento/dentro-mente-homens-687448.shtml>.. e <http://mulher.uol.com.br/ comportamento/noticias/redacao/2013/09/23/descubra-por-que-os-homens-traem-mais-do-que-asmulheres.htm>. 
feminino com a natureza se tornaram um forte argumento para evitar (ou retardar) a conquista das mulheres de seu espaço na esfera produtiva. ${ }^{64}$

Para Sherry B. Ortner, “a mulher não está 'na realidade' mais próxima (ou mais distante) da natureza do que o homem, ambos têm consciência e ambos são mortais", porém, representar a mulher como mais próxima da natureza é socialmente interessante, porque a concepção de que a cultura domina a natureza serve de base para justificar a desvalorização das mulheres e a dominação masculina. O resultado é um sistema de retroalimentação, em que diversos "aspectos da situação feminina (física, social e psicológica) contribuem para ela ser considerada como mais próxima da natureza", ao mesmo tempo em que "esta proximidade é incorporada em formas institucionais que lembram sua situação". ${ }^{65}$

Verificamos que, há vários séculos, especialistas impõem constatações sobre o fato de que falta nas mulheres "calor suficiente" para ferver o sangue e purificar a alma, que suas cabeças são pequenas demais, seus úteros grandes demais e seus hormônios debilitantes demais, que elas pensam com o coração ou com o lado errado do cérebro. ${ }^{66}$ Essa história não terá fim enquanto a permeabilidade entre conhecimento científico e contexto cultual não for atentamente investigada, revelando a articulação entre a produção médica e os modelos de relações de gênero em curso. Nesse sentido, “estudos que, por exemplo, focalizam a questão de gênero no século XIX podem contribuir muito para que se tenha uma análise mais profunda dos padrões de relações de gênero em vigor atualmente", pois auxiliam na identificação das rupturas e continuidades de determinados fenômenos. ${ }^{67}$

Portanto, não apenas gênero é o "conjunto de representações sociais construídas a partir das condições biológicas das diferenças entre os sexos", ${ }^{68}$ mas também a própria noção de sexo, enquanto conjunto de processos biológicos, é “produto

\footnotetext{
${ }^{64}$ ROHDEN, Fabíola. Uma ciência da diferença: sexo e gênero na medicina da mulher. Rio de Janeiro: Editora FIOCRUZ, 2001. p. 216-217.

${ }^{65}$ ORTNER, Sherry B. Está a mulher para o homem assim como a natureza para a cultura? In: ROSALDO, Michelle; LAMPHERE, Louise. A mulher, a cultura e a sociedade. Rio de Janeiro: Paz e Terra, 1979. p. 95-120. p. 118.

${ }^{66}$ HESS, Beth. B. Beyond Dichotomy: drawing distinctions and embracing differences. Sociological Forum, v. 5, n. 1, p. 75-93, 1990. p. 81.

${ }^{67}$ ROHDEN, Fabíola, op. cit., p. 19-24.

${ }^{68}$ SOUZA-LOBO, Elizabeth. A classe operária tem dois sexos: trabalho, dominação e resistência. 2 ed. São Paulo: Editora Fundação Perseu Abramo, 2011. p. 184.
} 
do discurso biomédico da cultura ocidental" ${ }^{69}$ Precisamos nos conformar com o fato de que o conhecimento científico, que sempre serviu de paradigma para o entendimento sobre as diferenças entre os sexos, sobre hormônios e sobre desenvolvimento do cérebro, também se constrói de acordo com o contexto histórico e social, carregando suas marcas.

Isso não quer dizer que a Biologia é irrelevante ou que os corpos femininos e masculinos não são diferentes, mas sim que certas diferenças adquirem destaque e significado dentro de sistemas de valores que são culturalmente definidos. ${ }^{70}$ Ressaltamos, enfim, que os genes não determinam nossos corpos ou cérebros, mas os restringem, de modo que as "possibilidades de desenvolvimento para uma pessoa não são nem infinitamente maleáveis nem estão exclusivamente nas mãos do ambiente". A própria Biologia é socialmente influenciada, modificando-se em interação com a nossa mente e nosso ambiente, ela "nunca é irrelevante, mas tampouco é determinante". 71

\subsubsection{Gênero, relações sociais de sexo e divisão sexual do trabalho}

Cunhado no final dos anos 1960 por antropólogas norte-americanas, o termo gênero (gender) foi erigido em oposição ao sexo biológico, de modo a designar a construção dos sexos pela cultura e História, ou seja, "a diferença entre os sexos em sua historicidade". ${ }^{72} \mathrm{O}$ intuito era de explicitar a preocupação em desnaturalizar identidades sexuais da teoria feminista, expondo as relações desiguais entre homens e mulheres.

As sociedades humanas sobrevalorizam a diferenciação biológica, conforme afirma Nicole-Claude Mathieu, de modo a atribuir funções distintas e hierarquizadas por meio da imposição cultural do gênero "feminino" à fêmea, para que se torne uma mulher social, e da imposição do gênero "masculino" ao macho, para que se torne um homem social. Assim,

\footnotetext{
${ }^{69}$ MOORE, Henrietta. Understanding Sex and gender. In INGOLD, Tim (org.). Companion Encyclopedia of Antropology. London: Routledge, 1997. (Tradução de Júlio Assis Simões para uso didático). p. 6-7.

${ }^{70}$ ORTNER, Sherry B. Está a mulher para o homem assim como a natureza para a cultura? In: ROSALDO, Michelle; LAMPHERE, Louise. A mulher, a cultura e a sociedade. Rio de Janeiro: Paz e Terra, 1979. p. 95-120. p. 99.

${ }^{71}$ FINE, Cordelia. Homens não são de Marte, mulheres não são de Vênus: como a nossa mente, a sociedade e o neurossexismo criam a diferença entre os sexos. São Paulo: Cultrix, 2012. p. 229-230.

${ }^{72}$ PERROT, Michelle. História (sexuação da). In: HIRATA, Helena; LABORIE, Françoise; LE DOARÉ, Hélène; SENOTIER, Danièle (org.). Dicionário Crítico do Feminismo. São Paulo: Editora Unesp, 2009. p. 111-116. p. 111.
} 
a extensão para a quase totalidade da experiência humana daquilo que é apenas uma diferenciação funcional em uma área leva a maioria dos seres humanos a pensar em termos de diferença entre os sexos como uma divisão ontológica irredutível em que o sexo e gênero coincidem e cada um deles é exclusivo em relação ao outro. Mas a gramática do gênero, ideal e factual, ultrapassa por vezes a "evidência" biológica de bicategorização - aliás, ela própria problemática - conforme o demonstraram a complexidade dos mecanismos de determinação dos sexos (...) e os estados intersexuais. ${ }^{73}$

Apesar de a separação entre gênero-social e sexo-biológico ter importância simbólica por enfatizar o caráter social das diferenças entre homens e mulheres, ela é problemática, conforme registado no trecho citado, pois oculta os fatos de que a construção dos gêneros envolve também o corpo e de que a própria natureza se transforma. Segundo Guacira Lopes Louro, "corremos o risco de ignorar ou de eliminar a biologia da história e do campo social", de forma que o caminho seria "evitar a polarização natural/social, possivelmente compreendendo que o gênero também tem uma dimensão e uma expressão biológica" ${ }^{74}$

No entanto, ao longo dos anos, a ideia do gênero foi lapidada, chegandose ao difundido conceito de Joan Scott, que possui duas partes: gênero é "elemento constitutivo de relações sociais baseadas nas diferenças percebidas entre os sexos" e, ao mesmo tempo, é "forma primária de dar significado às relações de poder", ou seja, "o gênero é um campo primário no interior do qual, ou por meio do qual, o poder é articulado". ${ }^{75}$ Segundo a autora, o gênero estrutura a "percepção e a organização concreta e simbólica da vida social" e, por estabelecer distribuições de poder que representam acesso diferente a recursos materiais e simbólicos, "o gênero torna-se implicado na concepção e na construção do próprio poder". ${ }^{76}$

No tocante a esta percepção do gênero como estruturante da vida social, entendemos ser necessária a complementação da teoria de Joan Scott e da noção de gênero com pressupostos teóricos do materialismo histórico, com o qual nos

\footnotetext{
${ }^{73}$ MATHIEU, Nicole-Claude. Sexo e gênero. In: HIRATA, Helena; LABORIE, Françoise; LE DOARÉ, Hélène; SENOTIER, Danièle (org.). Dicionário Crítico do Feminismo. São Paulo: Editora Unesp, 2009. p. 222-231. p. 223-224.

${ }^{74}$ LOURO, Guacira Lopes. Nas redes do conceito de gênero. In: LOPES, Marta Julia Marques; MEYER, Dagmar Estermann; WALDOW, Vera Regina. Gênero \& Saúde. Porto Alegre: Artes Médicas, 1996. p. 718. p. 11.

${ }^{75}$ SCOTT, Joan W. Gênero: uma categoria útil de análise histórica. Educação \& Realidade, Porto Alegre, v. 20, n. 2, p. 71-99, jul./dez. 1995. p. 87-88.

${ }^{76}$ Ibid., p. 88 .
} 
identificamos e que compreendemos serem fundamentais para os objetivos deste estudo. Nesse sentido, o conceito de "relações sociais de sexo" demonstra de modo mais claro a estrutura de opressão das mulheres em nossa sociedade, pois é construído em torno de uma base material, a divisão sexual do trabalho.

A expressão "relações sociais de sexo" é interessante a priori porque une a noção de relação social, que é fato da cultura, com o sexo, que é normalmente identificado como registro puramente biológico, gerando um efeito interrogativo e subversivo e forçando o questionamento do sexo para além da natureza. Ademais, a palavra "relação" deixa sempre a conotação de reciprocidade, o que possibilita expressar que sua abordagem envolve não apenas o grupo social das mulheres, mas também o dos homens. ${ }^{77}$

Assim, evidencia-se desde o início que o próprio "sexo" é uma construção social, não existindo a diferenciação entre "sexo-biológico" e "gênerosocial", e que as relações dadas entre esses dois sexos são necessariamente relações sociais, ou seja, relações antagônicas e inevitavelmente conflituosas. ${ }^{78}$ Por conseguinte, a construção do termo não deixa brechas para que seu significado original seja distorcido, como acontece hoje em dia com gênero, palavra polissêmica que muitas vezes é utilizada, de modo displicente e equivocado, como sinônimo (ou até eufemismo) de sexo, o que abre caminho para a naturalização dos papéis sociais de homens e mulheres, deixando de lado toda sua carga semântica.

Na definição de Danièle Kergoat, as relações sociais de sexo pressupõem a oposição entre grupos de interesses antagônicos, o grupo social dos homens e o grupo social das mulheres, que estão em tensão permanente em torno da questão do trabalho e de suas divisões. Tais relações têm como características: a ruptura com as explicações de cunho biológico das diferenças entre as práticas ditas masculinas e femininas; a afirmação de que tais diferenças são construções sociais, passíveis de serem apreendidas historicamente; a afirmação de que esta construção social não é unicamente ideológica,

\footnotetext{
${ }^{77}$ KERGOAT, Danièle. Relações sociais de sexo e divisão sexual do trabalho. In: LOPES, Marta Julia Marques; MEYER, Dagmar Estermann; WALDOW, Vera Regina. Gênero \& Saúde. Porto Alegre: Artes Médicas, 1996. p. 19-27. p. 25.

${ }^{78}$ Segundo Danièle Kergoat, "uma relação social é uma relação antagônica entre dois grupos sociais, instaurada em torno de uma disputa [enjeu]. (...) Toda relação social é, assim, uma relação conflituosa". KERGOAT, Danièle. Dinâmica e consubstancialidade das relações socais. Novos Estudos - CEBRAP [online], n. 86, p. 93-103, mar./2010. p. 94.
} 
mas tem uma base material; a percepção de que tais relações sociais baseiam-se em uma relação hierárquica entre os sexos, que é uma relação de poder, de dominação. ${ }^{79}$

Dessa forma, o conceito de relações sociais de sexo, desenvolvido pelas feministas materialistas francesas, permite uma visão sexuada dos fundamentos e da organização da sociedade. Por consequência, demonstra que homens e mulheres não são duas coleções de indivíduos biologicamente diferentes, mas sim "dois grupos sociais envolvidos numa relação social específica: as relações sociais de sexo", as quais, como todas as relações sociais, "possuem uma base material, no caso o trabalho, e se exprimem por meio da divisão sexual do trabalho". ${ }^{80}$

Apesar de suas origens históricas remotas, em épocas em que a família era a única base de sustentação da produção social, a estruturação atual da divisão sexual do trabalho surgiu com o modo de produção capitalista, que lhe atribui a principal característica: a separação e hierarquização das noções de produção e reprodução. Assim, foi atribuído ao sexo masculino o trabalho produtivo, destinado à produção de mercadorias, feito fora de casa, e ao sexo feminino o trabalho reprodutivo, naturalizado, descrito por Evelyn Nakano Glenn como "the labor that maintains people on a daily basis and intergenerationally - work that women traditionally expended in their roles as wives, mothers, and homemakers". 81

Segundo Helena Hirata e Danièle Kergoat, a divisão sexual do trabalho é forma modulada social e culturalmente, caracterizada pela

designação prioritária dos homens à esfera produtiva e das mulheres à esfera reprodutiva e, simultaneamente, a apropriação pelos homens das funções de maior valor social adicionado (políticos, religiosos, militares etc.). (...) Essa forma particular de divisão social do trabalho tem dois princípios organizadores: o princípio de separação (há trabalhos de homens e trabalhos de mulheres) e o princípio hierárquico (um trabalho de homem "vale" mais que um trabalho de mulher). ${ }^{82}$

\footnotetext{
${ }^{79}$ KERGOAT, Danièle. Relações sociais de sexo e divisão sexual do trabalho. In: LOPES, Marta Julia Marques; MEYER, Dagmar Estermann; WALDOW, Vera Regina. Gênero \& Saúde. Porto Alegre: Artes Médicas, 1996. p. 19-27. p. 21.

${ }^{80}$ Id., Divisão sexual do trabalho e relações sociais de sexo. In: HIRATA, Helena; LABORIE, Françoise; LE DOARÉ, Hélène; SENOTIER, Danièle (org.). Dicionário Crítico do Feminismo. São Paulo: Editora Unesp, 2009. p. 67-75. p. 67.

${ }^{81}$ GLENN, Evelyn Nakano. Cleaning Up/Kept Down: A Historical Perspective on Racial Inequality in “Women’s Work”. Sanford Law Review. v. 43. n. 6. p. 1333-1356. jul.1991. p. 1339.

${ }^{82}$ HIRATA, Helena. KERGOAT, Danièle. Divisão sexual do trabalho profissional e doméstico: Brasil, França, Japão. In: COSTA, Albertina de Oliveira. SORJ, Bila. BRUSCINI, Cristina. HIRATA, Helena (orgs). Mercado de Trabalho e Gênero: comparações internacionais. Rio de Janeiro: FGV, 2008. p. 263278. p. 266.
} 
Esta divisão é legitimada por meio do processo de naturalização dos papéis sociais sexuados, encarados como se fossem o destino biológico da espécie. Desvaloriza-se o trabalho reprodutivo realizado pelas mulheres no interior das residências para a sobrevivência da família, que culturalmente não é sequer considerado trabalho, mas sim "afazeres domésticos", vistos como obrigação das mulheres, vocação natural feminina, forma de dedicação amorosa. Tal processo gera o ocultamento e desvalorização do trabalho doméstico e de cuidado realizado pelas mulheres.

A problemática da divisão sexual do trabalho permite que se compreenda que o trabalho doméstico não remunerado e as particularidades do trabalho assalariado feminino não são exceções a um modelo supostamente geral de trabalho, mas sim a tentativa de repensar este modelo, no qual as relações de classe e relações de gênero não são hierarquizadas, mas sim conceitos interdependentes. Esta noção deve nortear não apenas os estudos relativos ao trabalho das mulheres, mas também as normas trabalhistas, caso contrário, corre-se o risco de que a normativa reforce a desigualdade entre os sexos no mercado de trabalho. ${ }^{83}$

Da ideologia de que os cuidados da casa, das crianças, idosos e doentes são de responsabilidade das mulheres, "mesmo daquelas que abandonam seu lugar tradicional na casa pelo trabalho na fábrica", resulta para as trabalhadoras um ciclo de trabalho praticamente contínuo, conhecido como dupla jornada ou "dupla situação opressora". ${ }^{84}$ Assim, a crescente participação das mulheres no mercado de trabalho não ocasionou mudanças na divisão sexual do trabalho, tanto que a tendência predominante ainda é de os homens investirem seu tempo prioritariamente na carreira profissional,

\footnotetext{
${ }^{83}$ Exemplo bem sucedido de dispositivo que incorporou esse conceito é o artigo 201 da CF, que confere às mulheres o direito de se aposentarem com menos tempo de contribuição à Previdência Social que os homens. Justifica tal opção normativa o fato de que recai sobre as mulheres não apenas a maternidade em si, mas os encargos de cuidados dos filhos, o que dificulta que a grande maioria da população feminina no país consiga ter uma vida produtiva linear. Portanto, presume-se que o tempo em que a mulher está afastada do trabalho remunerado corresponde ao tempo em que está contribuindo para a reprodução social, sem contrapartida financeira, motivo pelo qual não poderia seguir contribuindo formalmente para a Previdência. "A regra em comento deve ser interpretada como uma 'compensação' à mulher trabalhadora, uma tentativa de promover a igualdade de fato a partir do Direito", "comprometida com a melhora da condição social da mulher" (LOPES, Cristiane Maria Sbalqueiro. Direito do trabalho da mulher: da proteção à promoção. Cadernos Pagu, Campinas, n. 26, p. 405-430, 2006. p. 429). Ver também: HIGA, Flavio da Costa; VIEIRA, Regina Stela Corrêa. Proteção ou discriminação? Passando a limpo algumas normas de tutela do trabalho da mulher. Revista do Tribunal Superior do Trabalho, v. 21, n.1, Rio de Janeiro, p. 56-72, set./dez.2013.

${ }^{84}$ HIRATA, Helena. Nova Divisão Sexual do Trabalho? Um olhar voltado para a empresa e a sociedade. São Paulo: Boitempo, 2002. p. 137.
} 
enquanto as mulheres se dividem entre trabalho remunerado e trabalho doméstico não remunerado. ${ }^{85}$

A realidade da carga contínua de trabalho atribuída às mulheres pode ser demonstrada com atuais pesquisas sobre uso do tempo: são as mulheres que predominantemente são responsáveis pelo trabalho doméstico e que dedicam mais tempo a este tipo de tarefa. Segundo o Relatório Anual Socioeconômico da Mulher de 2013, entre as pessoas com 16 anos ou mais, 68\% das mulheres declaram realizar afazeres domésticos, em oposição a $32 \%$ dos homens. Além disso, entre as mulheres ocupadas, a dedicação ao trabalho doméstico é de 22,3 horas semanais, em oposição a 10,2 horas dedicadas pelos homens, o que significa que a jornada total das mulheres, somando-se trabalho remunerado e não remunerado, é em média de 58,5 horas semanais, enquanto a dos homens e de 52,7 horas por semana. ${ }^{86}{ }^{87}$ Outros desdobramentos da divisão sexual do trabalho na atualidade serão abordados mais adiante, ainda neste capítulo.

Desse modo, conforme Helena Hirata, o fundamental da compreensão da divisão sexual do trabalho é constatar, que "a exploração no trabalho assalariado e a opressão de sexo são indissolúveis", uma vez que a esfera da exploração econômica é ao mesmo tempo a esfera na qual se exerce o poder masculino. Existe uma relação de consubstancialidade $^{88}$ entre as relações de sexo, classe e raça, ou seja, um laço indissolúvel entre opressão sexual, econômica e racial, o que exige tomar o trabalho a

\footnotetext{
${ }^{85}$ SORJ, Bila. FONTES, Adriana. O care como um regime estratificado: implicações de gênero e classe social. In GUIMARÃES, N. A. HIRATA, H. S. (org.) Cuidado e cuidadoras: as várias faces do trabalho do care. São Paulo: Atlas, 2012. p. 105.

${ }^{86}$ BRASIL. Relatório Anual Socioeconômico da Mulher 2013. Brasília: Secretaria de Políticas para as Mulheres, 2013. p. 50-52.

${ }^{87}$ Em relação aos dados sobre uso do tempo, é importante ressalvar que, diferente do trabalho remunerado em que o tempo de trabalho é contratualmente definido, o trabalho doméstico não remunerado é orientado por tarefas cujo tempo de execução e a frequência varia significativamente. Por conta disso, pessoas que executam o trabalho doméstico geralmente não prestam atenção na quantidade de tempo demandada por cada tarefa, subestimam o tempo gasto ou nem mesmo se dão conta de estarem realizando tarefas, por serem executadas simultaneamente com outras ou por serem atos praticamente automáticos (LUXON, Meg. The UN, women, and household labour: Measuring and valuing unpaid work. Women's Studies International Forum, v. 20, n. 3, p. 431-439, 1997. p. 434). Desse modo, este tipo de pesquisa é bastante complexo e seus dados devem ser considerados com ressalvas, pois muitas vezes estão aquém do real tempo de dedicação ao trabalho doméstico.
}

${ }^{88}$ Ver: KERGOAT, Danièle. Dinâmica e consubstancialidade das relações socais. Novos Estudos CEBRAP [online], n. 86, p. 93-103, mar.2010. 
partir de uma perspectiva dinâmica, introduzindo a atuação da subjetividade que é, ao mesmo tempo, sexuada, de classe e de raça. ${ }^{89}$

Feitas estas distinções teóricas entre as noções de "gênero" e de "relações sociais de sexo", ${ }^{90}$ esclarecemos que no presente trabalho a opção foi por utilizá-las como sinônimos, uma vez que ambas se aproximam conceitualmente quando organizam a questão do poder, ${ }^{91}$ especialmente para possibilitar o diálogo com outros estudos brasileiros que optaram majoritariamente por utilizar "gênero", mas deixando claro que

(...) o gênero é relacional, quer enquanto categoria analítica, quer enquanto processo social, [de forma que] o conceito de relações de gênero deve ser capaz de captar a trama das relações sociais, bem como as transformações historicamente por ela sofridas através dos mais distintos processos sociais, trama esta na qual as relações de gênero têm lugar. As relações de gênero não resultam da existência de dois sexos, macho e fêmea (...). O vetor direciona-se, ao contrário, do social para os indivíduos que nascem. Tais indivíduos são transformados, através das relações de gênero, em homens ou mulheres, cada uma destas categorias-identidades excluindo a outra. ${ }^{92}$

O uso de ambos os termos tem como objetivo desnaturalizar as identidades "homem" e "mulher" e as relações desiguais entre os sexos, de modo a combater explicações essencialistas sobre a subordinação das mulheres em nossa sociedade. Portanto, tanto "gênero" quanto "sexo social" serão aqui empregados com objetivo de enfatizar o pressuposto de que as diferenças atribuídas aos sexos não são provenientes de uma causalidade biológica, mas possuem caráter histórico e, portanto, não são imutáveis, podendo e devendo ser questionadas.

Tornar claros, desde o início, os fundamentos a partir dos quais compreendemos as relações de gênero é fundamental para evitar que a ingenuidade permita que esta categoria seja instrumentalizada e torne-se vazia em seu sentido original de somar-se à busca por igualdade social. Isso porque, conforme retratado por

\footnotetext{
${ }^{89}$ HIRATA, Helena. Divisão - Relações sociais de sexo e do trabalho: contribuição à discussão sobre o conceito de trabalho. Em Aberto, Brasília, MEC/Inpe, v. 1, n. 65, p. 39-49, jan./mar.1995. p. 40.

${ }^{90}$ É preciso deixar claro que os conceitos aqui apresentados não esgotam os estudos de gênero, dentre os quais se destaca a teoria queer, surgida nos Estados Unidos, cuja referência é a filósofa Judith Butler, que buscou questionar e ir além do gênero (transgendering), compreendido como performance, de modo a perturbar as categorias de sexo e sexualidade. Ver: BUTLER, Judith P. Gender Trouble: feminism and the subversion of identity. New York, Routledge, 1990. BUTLER, Judith P. Bodies that matter, on the discursive limits of "sex". New York: Roudedge, 1993.

${ }^{91}$ OLIVEIRA, Eleonora Menicucci de. Gênero, saúde e trabalho: um olhar transversal. In: OLIVEIRA, Eleonora Menicucci de; SCAVONE, Lucila. (org). Trabalho, Saúde e Gênero na era da globalização. Goiânia: AB Editora, 1997. p. 1-14.

92 BRUSCHINI, Cristina; COSTA, Albertina de Oliveira da (orgs.). Uma questão de gênero. Rio de Janeiro: Rosa dos Tempos, 1992. p. 187.
} 
Nancy Fraser, na atual sociedade, observa-se que as lutas de gênero, ao mudarem seu foco majoritariamente da redistribuição para o reconhecimento, foram absorvidas pelo neoliberalismo, abandonando suas raízes de oposição ao sistema capitalista. ${ }^{93}$

A autora então propõe, e nos filiamos a seu pensamento, que para evitar o truncamento da problemática feminista com o neoliberalismo é preciso adotar um conceito de gênero mais amplo, que incorpore a problemática centrada no trabalho e associada ao feminismo materialista, ao mesmo tempo em que acomode a problemática centrada na cultura, associada a correntes intituladas "pós-marxistas" - compreendendo essas reivindicações como complementares ${ }^{94}$-, e que também leve em conta a atual economia globalizada e a supressão de fronteiras para o combate à injustiça.

Assim, é preciso partir de uma concepção de gênero tridimensional, alcançando três esferas do ordenamento social: a dimensão da distribuição, a dimensão do reconhecimento e a dimensão representação. Nancy Fraser explica que,

Pela perspectiva distributiva, gênero aparece como uma diferenciação semelhante à classe, enraizada na própria estrutura econômica da sociedade. Trata-se de um princípio básico para a organização da divisão do trabalho, dá sustentação à divisão fundamental entre trabalho "produtivo" pago e trabalho doméstico 'reprodutivo' não pago, sendo este último designado como responsabilidade primária das mulheres. (...) Como consequência, vemos uma estrutura econômica que gera formas específicas de injustiça distributiva, baseada em gênero. Pela perspectiva do reconhecimento, por outro lado, gênero aparece como uma diferenciação de status, enraizada na ordem de status da sociedade. Gênero codifica padrões culturais de interpretação e avaliação já disseminados, que são centrais na ordem de status como um todo. Portanto, uma das principais características da injustiça de gênero é o androcentrismo: um padrão institucionalizado de valor cultural que privilegia traços associados com a masculinidade, assim como desvaloriza tudo que seja codificado como 'feminino', paradigmaticamente - mas não somente - mulheres. $^{95}$

A terceira dimensão emerge, então, da conjuntura de combate à mádistribuição e ao não-reconhecimento, cujo fruto é o "mau enquadramento", ou seja, a imposição de esferas de poder transnacionais sobre pobres e desprezados, a quem é negada a chance de apresentar suas demandas por justiça. De acordo com a autora, a

\footnotetext{
${ }^{93}$ FRASER, Nancy. Políticas feministas na era do reconhecimento: uma abordagem bidimensional da justiça de gênero. In: BRUSCHINI, Cristina; UNBEHAUN, Sandra (orgs.). Gênero, democracia e sociedade brasileira. São Paulo: FCC, 2002. p. 59-78. p. 62.

${ }^{94}$ Ibid., p. 63-64.

${ }^{95}$ Ibid., p. 64-65.
} 
representação "não é apenas uma questão de assegurar voz política igual a mulheres em comunidades políticas já constituídas", mas de "reenquadrar as disputas sobre justiça que não podem ser propriamente contidas nos regimes estabelecidos". ${ }^{96}$

Os padrões androcêntricos tendem a ser institucionalizados, muitas vezes expressamente codificados em áreas do Direito, por meio de construções legais que partem de ideias sexistas sobre autonomia e a igualdade. Consequentemente, reparar as injustiças de gênero ratificadas pela ordem jurídica nacional e internacional exige que busquemos mudanças tanto na estrutura econômica quando na hierarquia de status existente na sociedade de hoje, pois a mudança em apenas uma delas não será suficiente. ${ }^{97}$

As normas trabalhistas, segundo Nancy Fraser, são exemplo de tal raciocínio: os esforços para reduzir as diferenças salariais entre homens e mulheres não terão o sucesso almejado se forem restritos à esfera econômica e não questionarem a divisão sexual do trabalho, que relega às profissões "femininas" salários mais baixos; da mesma forma que os esforços para combater os estereótipos de feminilidade no trabalho não terão sucesso se, permanecendo apenas na esfera da cultura, não questionarem condições econômicas estruturais. ${ }^{98}$

Portanto, "gênero" será aqui tomado como categoria de análise para o estudo do Direito, ou seja, uma ferramenta analítica que nos permitirá descobrir áreas desta ciência que normalmente não vêm à tona, visando a combater a omissão da tradição jurídica em relação ao sexo e, especialmente, em relação às mulheres.

\subsubsection{A atenção à diferença como meio de combater a desigualdade}

Se os tópicos anteriores permitiram formar a compreensão das relações de gênero e da construção social do próprio sexo, sob o argumento de que essa compreensão dará bases para a inserção da perspectiva de gênero no meio ambiente de trabalho, surgem dúvidas a respeito de como lidar com as particularidades constatadas

\footnotetext{
96 FRASER, Nancy. Mapeando a imaginação feminista: da redistribuição ao reconhecimento e à representação. Revista de Estudos Feministas, Florianópolis, v.15, n.2, p. 291-308, mai./ago. 2007. p. 304-305.

${ }^{97}$ Id., Políticas feministas na era do reconhecimento: uma abordagem bidimensional da justiça de gênero. In: BRUSCHINI, Cristina; UNBEHAUN, Sandra (orgs.). Gênero, democracia e sociedade brasileira. São Paulo: FCC, 2002. p. 59-78. p. 65.

98 Ibid., p. 76-77.
} 
no trabalho de homens e mulheres se, a princípio, a busca pela igualdade entre os sexos, eixo para o equilíbrio labor-ambiental, parece estar em oposição à afirmação da diferença.

Essa problemática foi desenvolvida por Joan Scott, sobre o que ela denomina de oposição binária da "igualdade-versus-diferença" (equality-versusdifference). Segundo a autora, colocar estes termos em oposição gera a falsa impressão de que é preciso optar entre a defesa da igualdade ou de sua aparente antítese, a diferença. ${ }^{99} \mathrm{Na}$ verdade, porém, estes conceitos são interdependentes, de modo que a igualdade não é "a ausência ou a eliminação da diferença, mas sim o reconhecimento da diferença e a decisão de ignorá-la ou de levá-la em consideração". ${ }^{100}$ De acordo com este raciocínio,

(...) when equality and difference are paired dichotomously, they structure an impossible choice. If one opts for equality, one is forced to accept the notion that difference is antithetical to it. If one opts for difference, one admits that equality is unattainable. (...) Feminists cannot give up "difference"; it has been our most creative analytic tool. We cannot give up equality, at least as long as we want to speak to the principles and values of our political system. But it makes no sense for the feminist movement to let its arguments be forced into preexisting categories and its political disputes to be characterized by a dichotomy we did not invent. How then do we recognize and use notions of sexual difference and yet make arguments for equality? The only response is a double one: the unmasking of the power relationship constructed by posing equality as the antithesis of difference and the refusal of its consequent dichotomous construction of political choices. ${ }^{101}$

Para Joan Scott, são os contextos que definem o interesse em afirmar a diferença, ou a necessidade de reforçar a igualdade. Exemplo disso são as relações de trabalho: diante da história trabalhista de exclusão das mulheres, faz sentido generalizar a experiência das trabalhadoras e enfatizar a diferença, com o objetivo de demonstrar que o termo universal "trabalhador" é uma referência masculina, que não vale para grande parte das experiências de trabalho das mulheres; já na relação com o empregador, que insiste em justificar a discriminação das mulheres com base em supostas diferenças biológicas, faz mais sentido negar a diferença. No primeiro caso, a

\footnotetext{
${ }^{99}$ SCOTT, Joan W. Deconstructing Equality-Versus-Difference: Or, the uses of Post-Structuralist Theory for Feminism. Feminist Studies, Maryland, v. 14, n. 1, p. 33-50, 1988. p. 38.

${ }^{100}$ Id., O enigma da igualdade. Estudos Feministas, Florianópolis, v. 13, n. 1, p. 11-30 abr.2005. p. 14-15.

101 Id., Deconstructing Equality-Versus-Difference: Or, the uses of Post-Structuralist Theory for Feminism. Feminist Studies, Maryland, v. 14, n. 1, p. 33-50, 1988. p. 43-44.
} 
diferença assume uma função positiva, revelando a iniquidade escondida em um suposto termo neutro, enquanto no segundo caso, a diferença serve a um propósito negative, sendo usada para justificar o tratamento discriminatório. ${ }^{102}$

Desse modo, a autora conclui que a igualdade, base das demandas por justiça dos grupos excluídos, significa ignorar as diferenças entre os indivíduos para um propósito particular ou em um contexto particular. Dentro dessa lógica, a busca pela igualdade tem como objetivo a eliminação não de todas as diferenças, mas de um conjunto particular de diferenças. Isso pressupõe um acordo social, no qual pessoas obviamente diferentes sejam consideradas como equivalentes para um determinado propósito, mas nunca idênticas. Assim, a noção política de igualdade inclui o reconhecimento da existência da diferença e depende dele, afinal, se os grupos ou os indivíduos fossem exatamente iguais, não haveria a necessidade de pedir a igualdade. ${ }^{103}$

Nas palavras de Guacira Lopes Louro, é preciso perceber que "o oposto igualdade é a desigualdade ou a equivalência (e não a diferença)". ${ }^{104}$ Assim, a pretensão ao enfatizar a igualdade não é negar as diferenças individuais, mas afirmar que essas diferenças "têm sido usadas como justificativas para tratamentos desiguais". ${ }^{105}$ Nesse sentido, Heleieth Saffioti afirma que

(...) a democracia exige igualdade social. Isto não significa que todos os socii, membros da sociedade, devam ser iguais. Há uma grande confusão entre os conceitos como: igualdade, diferença, desigualdade, identidade. Habitualmente, à diferença contrapõe-se a igualdade. Considera-se, aqui, errônea essa concepção. O par da diferença é a identidade. Já a igualdade, conceito de ordem política, faz par com a desigualdade. As identidades, como também as diferenças, são bemvindas. Numa sociedade multicultural, nem deveria ser de outra forma. ${ }^{106}$

Portanto, "ser igual" não pode ser confundido com "ser idêntico", ${ }^{107}$ de maneira que "as práticas sociais de mulheres podem ser diferentes das de homens da

\footnotetext{
102 SCOTT, Joan W. Deconstructing Equality-Versus-Difference: Or, the uses of Post-Structuralist Theory for Feminism. Feminist Studies, Maryland, v. 14, n. 1, p. 33-50, 1988. p. 41.

${ }^{103}$ Ibid., p. 44.

${ }^{104}$ LOURO, Guacira Lopes. Nas redes do conceito de gênero. In: LOPES, Marta Julia Marques; MEYER, Dagmar Estermann; WALDOW, Vera Regina. Gênero \& Saúde. Porto Alegre: Artes Médicas, 1996. p. 718. p. 14.

105 Ibid., p. 14.

${ }^{106}$ SAFFIOTI, Heleieth I. B. Gênero, patriarcado, violência. São Paulo: Fundação Perseu Abramo, 2004. p. 37.

${ }^{107}$ YANNOULAS, Silvia Cristina. Iguais mas não idênticos. Estudos Feministas, Florianópolis, v. 2, n. 3, p. 7-16, 1994. p. 10.
} 
mesma maneira que, biologicamente, elas são diferentes deles". ${ }^{108}$ Assim, no caso das relações de gênero, o desafio da igualdade não é tornar homens e mulheres idênticos, mas romper o esquema binário que polariza e hierarquiza masculino e feminino, processo no qual é fundamental falar das diferenças enquanto modo de reforçar as identidades individuais e coletivas. Agir de qualquer outro modo seria aceitar o argumento político de que a similitude é um requisito para a igualdade. ${ }^{109}$

Nas relações de trabalho, as mulheres não são trabalhadoras idênticas aos homens e não pretendem ser. A busca pela igualdade precisa considerar as especificidades que o sexo e o gênero atribuem a trabalhadores e trabalhadoras, devendo o sistema jurídico ser sensível às diferenças, mas sem reproduzir o preconceito. No entanto, a tendência da legislação brasileira tem sido a oposta, não contemplando as diferenças entre homens e mulheres quando elas são necessárias para preservação da sua sanidade, mas agindo de forma protetora com as mulheres, por conta de seu papel social na reprodução. ${ }^{110}$

Nesse sentido, importante pontuar que a igualdade é o valor que fundamenta o Direito do Trabalho, mas não a igualdade formal do liberalismo, sim a igualdade material, que visa a reduzir a desigualdade própria das relações de trabalho. Este ramo do Direito, segundo Oscar Ermida Uriarte, "não é um ordenamento jurídico igual para todos, senão desigualador ou compensatório", de modo que "a desigualdade é o fundamento último da proteção" e "se não fosse por ela, a proteção não se justificaria". 111

\footnotetext{
${ }^{108}$ SAFFIOTI, Heleieth I. B. Gênero, patriarcado, violência. São Paulo: Fundação Perseu Abramo, 2004. p. 116.

${ }^{109}$ Entretanto, enfatizamos que este posicionamento não pressupõe que ignoremos as diferenças entre as próprias mulheres. Na verdade, a tentativa de conferir à categoria "mulheres" um conteúdo universal também gera desigualdades, pois demanda a criação de padrões "gerais" do feminino, o que sempre terá como consequência a exclusão daquelas que neles não se enquadram. Isso não significa dizer, como explica Judith Butler, que a utilização "mulheres" deve ser negada, mas sim que o termo deve abrigar "um campo de diferenças indesignável, que não pode ser totalizado ou resumido por uma categoria de identidade descritiva", tornando-se "um lugar de permanente abertura e ressignificação". (BUTLER, Judith. Fundamentos contingentes: o feminismo e a questão do "pós-modernismo". Cadernos Pagu, São Paulo, n. 11, p. 11-28, 1998. p. 25.).

${ }^{110}$ LOBO, Elisabeth Souza. O trabalho como linguagem: o gênero do trabalho. In: BRUSCHINI, Cristina; COSTA, Albertina de Oliveira da (orgs.). Uma questão de gênero. Rio de Janeiro: Rosa dos Tempos, 1992. p. 252-265. p. 262.

${ }^{111}$ ERMIDA URIARTE, Oscar. Prefácio. In: LIMA, Firmino Alves. Teoria da discriminação nas relações de trabalho. Rio de Janeiro: Elsevier, 2011. p. XII-XIII.
} 


\subsection{A influência do gênero sobre os riscos ocupacionais}

Delimitadas as bases teóricas do presente trabalho, voltamos nosso foco à compreensão da influência das relações de gênero na saúde e segurança das trabalhadoras e trabalhadores, uma vez que os modos de viver e resistir às condições de trabalho também são sexuados ${ }^{112}$, alterando os riscos ocupacionais a que homens e mulheres estão expostos e criando a necessidade de que o estudo da proteção laborambiental leve a categoria gênero em consideração.

Nesse sentido, o gênero é fundamental na pretensão de tornar visível a dinâmica saúde-trabalho para as mulheres, que deve levar em consideração, por exemplo, a sobrecarga de trabalho que recai sobre elas, uma vez que, conforme visto anteriormente, a divisão sexual do trabalho impõe longas jornadas de trabalho, associadas às responsabilidades familiares e aos menores recursos de que dispõem, que representam grande desgaste físico e emocional, contribuindo para a deterioração progressiva da saúde feminina. ${ }^{113}$

Nos dias de hoje, porém, essa análise torna-se mais complexa, devido às novas configurações da divisão sexual do trabalho, que podem ser percebidas desde a década de 1990. Helena Hirata, Leila Blass e Vera Soares apontam três características mais recentes do trabalho das mulheres, concomitantes ao processo de globalização econômica e financeira: a bipolarização do emprego feminino; a precarização e vulnerabilidade dos empregos criados a partir da década de 1990; e a globalização do trabalho reprodutivo. ${ }^{114}$

A primeira diz respeito à criação de dois polos de trabalho feminino, um majoritário, constituído por setores tradicionalmente femininos, como educação, saúde, serviços e comércio, e outro minoritário, constituído de profissões valorizadas e relativamente bem remuneradas, ocupadas em maioria por mulheres brancas, não imigrantes e qualificadas, como médicas, advogadas, juízas, professoras universitárias

\footnotetext{
112 OLIVEIRA, Ana Cristina Oliveira de. Gênero, saúde reprodutiva e trabalho: formas subjetivas de viver e resistir às condições de trabalho. Dissertação (Mestrado em Saúde Pública) - Escola Nacional de Saúde Pública, Fundação Oswaldo Cruz, Rio de Janeiro. 2001. p. 22.

${ }^{113}$ BRITO, Jussara Cruz de. Enfoque se gênero e relação saúde/trabalho no contexto de reestruturação produtiva e precarização do trabalho. Caderno de Saúde Pública, Rio de Janeiro, n. 16, v. 1, p. 195-204, jan-mar 2000. p. 202-203.

${ }^{114}$ BLASS, Leila; HIRATA, Helena; SOARES, Vera. Prefácio à $2^{a}$ edição. SOUZA-LOBO, Elizabeth. A classe operária tem dois sexos: trabalho, dominação e resistência. 2 ed. São Paulo: Editora Fundação Perseu Abramo, 2011. p. 9-20. p. 11.
} 
etc.. A segunda característica revela o crescimento da instabilidade de trabalho e a supressão dos empregos formais vista em todo o mundo desde os anos 1990. Por fim, a terceira, refere-se à expansão dos ofícios relacionados aos cuidados (care), determinada pela mercantilização e externação de trabalhos tradicionalmente alocados às mulheres na esfera privada, intimamente relacionada ao aumento dos fluxos migratórios internacionais. $^{115}$

Desse modo, apesar de terem ocorrido mudanças e de as mulheres terem conquistado seu espaço no mercado de trabalho, os novos contornos da divisão sexual do trabalho deixam persistir a própria divisão sexual, "cujo paradigma se assenta tanto na hierarquia social, conferindo superioridade do masculino sobre o feminino, quanto na divisão sexual do trabalho doméstico", cujas mudanças são incomparavelmente mais lentas. ${ }^{116}$ Consequentemente, é preciso que a análise da saúde e segurança do trabalho leve em consideração as mudanças e continuidades do trabalho das mulheres, caso contrário, manter-se-ão cegas à sua influência sobre os riscos labor-ambientais que afligem as trabalhadoras. Essa é a proposta para os itens a seguir.

\subsubsection{A organização do trabalho e segregação ocupacional por sexo}

A saúde e segurança no trabalho são consequência de complexas e dinâmicas relações entre trabalhadores e trabalhadoras com sua atividade, as condições e o meio nos quais as exercem. Sendo assim, o avanço tecnológico das últimas décadas, com a alteração fundamental na organização do trabalho, determina a transferência e mudança no perfil epidemiológico dos riscos no trabalho, merecendo destaque o aumento do sofrimento mental. ${ }^{117}$

Atualmente, observa-se uma inserção diferencial de mulheres e homens no mercado de trabalho, fenômeno conhecido como segregação ocupacional ou

\footnotetext{
${ }^{115}$ BLASS, Leila; HIRATA, Helena; SOARES, Vera. Prefácio à $2^{\text {a }}$ edição. SOUZA-LOBO, Elizabeth. A classe operária tem dois sexos: trabalho, dominação e resistência. 2 ed. São Paulo: Editora Fundação Perseu Abramo, 2011. p. 9-20. p. 11.

${ }^{116}$ HIRATA, Helena. Reorganização da produção e transformações do trabalho: uma nova divisão sexual do trabalho? In: BRUSCHINI, Cristina; UNBEHAUN, Sandra (orgs.). Gênero, democracia e sociedade brasileira. São Paulo: FCC, 2002. p. 339-355. p. 352.

${ }^{117}$ OLIVEIRA, Eleonora Menicucci de. Corpos saudáveis e corpos doentes na nova organização social do trabalho. In: ROCHA, Maria Isabel Baltar da. (org). Trabalho e Gênero: Mudanças, Permanências e Desafios. São Paulo: Editora 34, 2000. p. 237-256.
} 
segregação setorial por sexo ${ }^{118}$, que possui duas formas: a segregação horizontal, manifestada na distribuição diferenciada dos sexos em ocupações e ramos de atividade; e a segregação vertical, que reflete as dificuldades que as mulheres ainda enfrentam para ascender a cargos de responsabilidade e prestígio. ${ }^{119}$

No caso da segregação horizontal do mercado de trabalho, constata-se que as mulheres estão concentradas em setores de atividade específicos, determinados em função de estereótipos de gênero. Assim, as ocupações femininas são geralmente derivadas das funções de reprodução social, quando não extensões diretas do trabalho doméstico não remunerado, requerendo das mulheres qualidades estimuladas na socialização das meninas, como paciência, docilidade, meticulosidade e delicadeza. ${ }^{120}$

Ricardo Antunes, ao descrever as principais características da classe trabalhadora nos dias de hoje, que denomina "novos proletários", ressalta o aumento expressivo do trabalho feminino e constata que "o capital reconfigurou uma nova divisão sexual do trabalho". Segundo o autor, "nas áreas onde é maior a presença de capital intensivo, de maquinário mais avançado, predominam os homens", enquanto "nas áreas de maior trabalho intensivo, onde é maior ainda a exploração do trabalho manual, trabalham as mulheres". 121

Nesse contexto, apesar de teses que insistem no surgimento de um novo paradigma de organização da produção substitutivo ao fordismo, constata-se que este modelo não foi extinto, principalmente quando considerada a força de trabalho feminina e as indústrias de países subdesenvolvidos. A tendência é que as novas tecnologias reforcem a marginalidade das mulheres não qualificadas, pois eliminam postos não qualificados, restando aqueles caracterizados por tarefas repetitivas e minuciosas, que predominantemente empregam mulheres. ${ }^{122}$

\footnotetext{
${ }^{118}$ SALAS, Carlos. LEITE, Marcia. Segregação setorial por gênero: uma comparação Brasil-México. In: COSTA, Albertina de Oliveira. SORJ, Bila. BRUSCINI, Cristina. HIRATA, Helena (orgs). Mercado de Trabalho e Gênero: comparações internacionais. Rio de Janeiro: FGV, 2008. p. 89-106.

${ }^{119}$ ESPAÑA. Herramienta de apoyo $\mathrm{n}^{\circ}$ 10: Salud y riesgos laborales con perspectiva de género. Madrid: Ministerio de Sanidad, Servicios Sociales e Igualdad, 2010. Disponível em: <http://www.igualdadenlaempresa.es/recursos/herramientas/home.htm>. Acesso em: 16.ago.2014. p. 6.

${ }^{120}$ YANNOULAS, Silvia C. Gênero e mercado de trabalho: situando a problemática. In YANNOULAS, Silvia C. (coord.). A convidada de pedra: mulheres e políticas públicas de trabalho e renda. Brasília, FLACSO, 2003. p. 48-62.

${ }^{121}$ ANTUNES, Ricardo. Os sentidos do trabalho: ensaio sobre a afirmação e a negação do trabalho. São Paulo: Boitempo, 2009. p. 200.

${ }^{122}$ Nas últimas décadas, ocorreram grandes avanços em relação à inserção das mulheres e ao aumento de sua qualidade de vida no trabalho. No entanto, frisamos aqui que estamos comparando os avanços divididos por sexo, que se mantém ao longo da história e, de modo geral, são reforçados pelas novas
} 
Exigidas para estes tipos de tarefa, as qualificações consideradas femininas são aquelas forjadas ao longo da vida e da história das mulheres, que aprendem e desenvolvem habilidades nos trabalhos domésticos e na convivência social, mas que não são valorizadas pela sociedade capitalista e sexista. ${ }^{123}$ Mesmo que os conhecimentos adquiridos cotidianamente pelas mulheres sejam centrais para o desenvolvimento do trabalho produtivo, e explorados pelo empregador, não são equiparados aos conhecimentos formais advindos de cursos e treinamentos profissionalizantes.

Conforme descreve Elisabeth Souza-Lobo, as qualificações femininas são socialmente consideradas "talentos", de forma a não configurarem qualificações formais e, consequentemente, não encontrarem correspondência salarial ou no nível da carreira. "As habilidades femininas para o trabalho industrial são consideradas intatas e não são consideradas "qualificações" - destreza, rapidez, concentração, disciplina para o trabalho rotineiro etc. -, pois dispensam cursos e diplomas”. Dessa lógica simplificase a desvalorização do trabalho feminino como se fosse uma questão de falta de formação das mulheres, ao invés de ser compreendida como uma questão de reconhecimento das qualificações já possuídas pelas trabalhadoras. ${ }^{124}$

Por conta disso, precisamos usar o termo qualificação com cautela, porque "as análises sobre a desqualificação representam, na maior parte do tempo, os interesses de uma parcela mais privilegiada da força de trabalho", uma vez que geralmente consideram-se as ocupações masculinas como qualificadas, enquanto as femininas são vistas como instintivas e simples. É necessário ampliar a ideia de qualificação, para que passe a considerar todos os saberes que o indivíduo possui para

tecnologias. Ademais, neste tipo de análise é preciso reforçar a interseccionalidade das questões de gênero, raça e classe, que permitem revelar que, apesar de um número representativo de mulheres ter hoje acesso às novas tecnologias, a maior parte delas permanece excluída, ou limitadas ao uso da tecnologia provido pelo aumento dos padrões de consumo no país.

${ }^{123}$ A desvalorização do conhecimento tradicional das mulheres na atual sociedade tem paralelo com a desvalorização da cultura popular, do folclore e das brincadeiras tradicionais, passadas de mãe para filhas e filhos, considerados inferiores em um mundo masculino, competitivo, sério e apressado. A sociedade capitalista contemporânea baseia-se na ciência do que é passível de ser quantificado, padroniza o comportamento das mulheres, medicaliza a energia para brincar das crianças, desdenha da razão das matriarcas e abandona as cantigas e danças populares. Documentário essencial sobre o tema é "Tarja Branca: a revolução que faltava”, 2014, direção Cacau Rohden.

${ }^{124}$ SOUZA-LOBO, Elisabeth. A classe operária tem dois sexos. São Paulo: Editora Fundação Perseu Abramo, 2011. p. 258-259. 
desempenhar seu trabalho, independente se acumulado por meio da educação formal, formação profissional ou se por meio do processo de socialização. ${ }^{125}$

A segregação horizontal não é apenas de postos de trabalho reservados às mulheres dentro das fábricas, mas também das áreas de conhecimento para as quais elas estarão majoritariamente voltadas, conforme revelam os dados brasileiros sobre a distribuição da população ocupada por ramos de atividade: em 2013, as mulheres concentravam-se em setores do mercado de trabalho relacionados aos papéis tradicionalmente femininos, como alojamento e alimentação, educação, saúde e serviços sociais, sendo que $45 \%$ da força de trabalho feminina estava alocada em tais serviços sociais, categoria que engloba os serviços domésticos; já os homens concentram $48 \%$ de sua força de trabalho nos setores agrícola, industrial e de construção. ${ }^{126}$

O emprego doméstico foi por longo tempo ignorado socialmente, considerado um "não trabalho", o que resultou em uma legislação trabalhista que até hoje não equipara os serviços domésticos ao trabalho urbano e rural. ${ }^{127}$ A justificativa deste tipo de tratamento se origina da concepção de que cuidar das necessidades da família e da casa seria uma expressão da natureza feminina. Essa noção é estendida aos trabalhos comumente desenvolvidos por mulheres, como a enfermagem, o magistério, a secretaria e a faxina, de modo que as competências requeridas são vistas como meros prolongamentos da vocação feminina para o trabalho reprodutivo, do que decorre sua desprofissionalização. ${ }^{128}$

Thierry Ribault explica que a lógica de desvalorização do trabalho exercido por uma maioria de mulheres, especialmente quando relacionado ao cuidado, tem relação com um pressuposto de que as competências exigidas para o exercício de funções consideradas femininas "são da mesma natureza, se não simples prolongamentos, das aptidões desenvolvidas na esfera doméstica". Assim, a

\footnotetext{
${ }^{125}$ SOARES, Angelo. Automação, (des)qualificação e emoção nos paraísos de consumo. Cadernos Pagu, Campinas, v. 10, p. 113-146, 1998. p. 125-128.

${ }^{126}$ BRASIL. Relatório Anual Socioeconômico da Mulher 2013. Brasília: Secretaria de Políticas para as Mulheres, 2013. p. 45.

${ }^{127}$ O não reconhecimento do trabalho doméstico como trabalho igual aos demais fica claro quando a CLT, de 1943, exclui este tipo de serviço de sua aplicação. Assim, o trabalho doméstico só foi regulado em 1972, pela Lei 5.859. A CF, apesar de ampliar os direitos dessas trabalhadoras e trabalhadores, deixou claro no artigo $7^{\circ}$ que não se equiparam aos urbanos e rurais. Vale mencionar, inclusive, que a recente EC n. 72, de 2013, apesar de representar um grande avanço na proteção da categoria, também não conseguiu sua equiparação às demais.

${ }^{128}$ ROMITO, Patrizia. Trabalho, maternidade e saúde das mulheres: algumas notas metodológicas. In: OLIVEIRA, Eleonora Menicucci de; SCAVONE, Lucila. (org). Trabalho, Saúde e Gênero na era da globalização. Goiânia: AB Editora, 1997. p. 15-27.
} 
“invisibilidade das qualificações mescla-se àquela das condições de trabalho para valorizar apenas minimamente estas atividades de forte conteúdo relacional". ${ }^{129}$

Vale frisar que a segregação horizontal é reforçada pela segmentação que ocorre na formação profissional. No Brasil, apesar de as mulheres dedicarem-se mais aos estudos, 37,3\% delas têm 11 anos ou mais de estudo, em face a 32,6\% dos homens ${ }^{130}$, e serem a maioria entre ingressantes e concluintes do ensino superior, respectivamente $55,8 \%$ e $61,1 \%$, ainda assim continuam buscando majoritariamente profissões que envolvam conhecimentos relacionados aos papéis sociais femininos, evitando profissões nas ciências exatas: áreas que envolvem ciências da educação, secretariado e serviço social têm aproximadamente $90 \%$ de suas matrículas feitas por mulheres, enquanto engenharia mecânica, áreas de automação e ciências da computação concentram percentuais entre $90 \%$ e $85 \%$ de homens matriculados. ${ }^{131}$

Dessa forma, as ocupações que demandam conhecimentos considerados femininos, ou que empregam elevados contingentes de mulheres, devido a tais características de gênero, possuem menor prestígio e níveis mais baixos de remuneração. ${ }^{132}$ Esse processo, derivado da segregação por sexo no contexto da reestruturação produtiva, é conhecido como "feminização de uma profissão", termo que demonstra nestes casos um processo de desvalorização e perda de prestígio de determinado exercício profissional. ${ }^{133}$ Fica explícita a existência de um processo dialético em que as tarefas desvalorizadas são destinadas às mulheres, bem como tarefas em que as mulheres se concentram passam a ser desvalorizadas.

O caminho de mão dupla entre valorização e desvalorização profissional pelo gênero pode ser observado na relação entre trabalho feminino e tecnologia, definida muito mais por seu conteúdo ideológico, que discrimina as mulheres, do que

\footnotetext{
${ }^{129}$ RIBAULT, Thierry. Cuidadoras domiciliares: que tipo de profissionalização? In GUIMARÃES, N. A. HIRATA, H. S. (org.) Cuidado e cuidadoras: as várias faces do trabalho do care. São Paulo: Atlas, 2012. p. 124.

${ }^{130}$ INSTITUTO BRASILEIRO DE GEOGRAFIA E ESTATÍSTICA. Pesquisa Nacional por Amostra de Domicílios: Síntese de Indicadores 2012. Rio de Janeiro: IBGE, 2013. p. 109.

${ }^{131}$ BRASIL. Relatório Anual Socioeconômico da Mulher 2013. Brasília: Secretaria de Políticas para as Mulheres, 2013. p. 78-80.

132 BRUSCHINI, Cristina; LOMBARDI, Maria Rosa. Instruídas e trabalhadeiras. Cadernos Pagu, Campinas, n. 17-18, p. 157-196, 2002. p. 186.

${ }^{133}$ KERGOAT, Prisca; PICOT, Geneniève; LADA, Emmanuelle . Ofício, profissão, 'bico'. In: HIRATA, Helena; LABORIE, Françoise; LE DOARÉ, Hélène; SENOTIER, Danièle (org.). Dicionário Crítico do Feminismo. São Paulo: Editora Unesp, 2009. p. 159-167.
} 
pela competência técnica. ${ }^{134}$ Exemplo perfeito é o das programadoras de computadores: quando a programação não era prestigiada, as mulheres eram maioria na profissão, considerada meticulosa e repetitiva, portanto, melhor relacionada com as "qualidades femininas"; porém, quando programar tornou-se atividade de prestígio, por ser central na tecnologia da computação, homens passaram a dominar a profissão, que passou a ser vista como trabalho intelectual, que exige raciocínio lógico e realização de tarefas de alta complexidade. ${ }^{135}$

Além da segregação horizontal, as relações de gênero também influenciam a segregação vertical do mercado de trabalho, que cria desvantagem das mulheres em relação aos homens, em termos de salário, ascensão profissional e condições de trabalho. Silvia Cristina Yannoulas lança mão do conceito de "pirâmide ocupacional baseada em gênero" para descrever o fato de as mulheres contarem com "menos possibilidades de promoção a cargos mais altos que os homens". 136

A lógica que determina a concentração das mulheres em certos tipos de atividades e profissões é a mesma que interfere na ascensão das mulheres no trabalho e no reconhecimento do valor de seu trabalho, o que se reflete na defasagem salarial: tal como as mulheres são identificadas com atividades "femininas", a competência para liderança é considerada uma característica masculina, bem como se presume que mulheres são menos dedicadas ao trabalho por "naturalmente" preocuparem-se mais com as questões domésticas.

Isso se reflete nas diferenças salariais entre homens e mulheres, que ainda são constatadas no Brasil: em 2011, o rendimento-hora da população ocupada era de $\mathrm{R} \$ 11,10$ entre os homens e de $\mathrm{R} \$$ 9,20 entre as mulheres, sendo que entre as pessoas mais escolarizadas, a diferença é ainda maior, de modo que as mulheres com mais de 12 anos de estudo recebem cerca de $65 \%$ dos rendimentos de homens na mesma

\footnotetext{
${ }^{134}$ NEVES, Magda de Almeida. Reestruturação produtiva, qualificação e relações de gênero. In: ROCHA, Maria Isabel Baltar da. (org). Trabalho e Gênero: Mudanças, Permanências e Desafios. São Paulo: Editora 34, 2000. p. 171-185. p. 179.

${ }^{135}$ O primeiro grande computador, Eniac, desenvolvido em 1943, foi programado por mulheres. Depois de décadas de esquecimento, esta história foi resgatada pelo documentário "ENIAC Programmer Project", de Kathy Kleiman. Mais informações disponíveis em: <http://eniacprogrammers.org/>..

136 YANNOULAS, Silvia Cristina. Gênero e mercado de trabalho: situando a problemática. In YANNOULAS, Silvia Cristina. (coord.). A convidada de pedra: mulheres e políticas públicas de trabalho e renda. Brasília, FLACSO, 2003. p. 48- 62.
} 
condição. ${ }^{137}$ Também se reflete no baixo índice de mulheres que atingem cargos de direção, que em 2011 ocupavam apenas 36,2\% desde postos. ${ }^{138}$

A crença de que mulheres não são capazes o suficiente para assumirem cargos de direção ou chefia influencia no seu reconhecimento institucional, o que faz com que elas precisem, na maioria das vezes, esforçar-se muito mais que os homens nas mesmas funções, pois eles são os preferencialmente promovidos. Virginia Schein descreveu este fenômeno por meio da expressão "think manager-think male", com base em estudos iniciados nos anos 1970, nos Estados Unidos, que demonstraram que estava enraizado na mente de gerentes o pensamento que atrelava o sucesso gerencial a características masculinas. ${ }^{139} \mathrm{Na}$ década de 1990, a pesquisa foi atualizada e expandida para Japão, China, Grã-Bretanha e Alemanha, mas ainda assim, e a despeito das conquistas femininas no mercado de trabalho, gerentes dos cinco países e de ambos os sexos, com exceção das mulheres gerentes estadunidenses,

(...) continue to perceive the managerial position as requiring masculine characteristics. To the extent this attitude is unchecked by structural limitations, the male decision-maker may still favor the male candidate. As a psychological barrier to the advancement of women in management, the "think manager-think male" phenomenon can foster bias against women in managerial selection, placement, promotion and training decisions. ${ }^{140}$

No Brasil, Nereida Salette Paulo da Silveira, em pesquisa sobre a experiência das mulheres em cargos de alta gerência, relata que mesmo inseridas nas organizações, as mulheres ainda enfrentam barreiras para uma real inclusão, fato que tem origem nos estereótipos que envolvem tanto os papéis de gênero, quanto o papel de gerente, levando muitas dessas mulheres a tentarem se "desfeminizar" para conseguirem exercer suas funções. ${ }^{141} \mathrm{O}$ gênero, assim, está diretamente ligado à interpretação do que é uma liderança dentro do ambiente de trabalho, sendo o sucesso e o bom desempenho profissional associados à masculinidade. Segundo a autora,

\footnotetext{
${ }^{137}$ BRASIL. Relatório Anual Socioeconômico da Mulher 2013. Brasília: Secretaria de Políticas para as Mulheres, 2013. p. 48.

${ }^{138}$ Ibid., p. 139.

${ }^{139}$ SCHEIN, Virginia E.; MUELLER, Ruediger; LITUCHY, Terri; LIU, Jiang. Think manager-think male: a global phenomenon? Journal of Organizational Behavior, v. 17, p. 31-44, 1996. p. 33.

${ }^{140}$ Ibid., p. 34.

${ }^{141}$ SILVEIRA, Nereida Salette Paulo da. Entendendo a experiência de inclusão-exclusão de mulheres em cargos de alta gerência. In: XXXIII Encontro da Associação Nacional de Programas de Pós-graduação e Pesquisa em Administração, 2009, São Paulo. Anais do EnANPAD 2009. Rio de Janeiro: ANPAD, 2009. 14 p. p. 6.
} 
(...) mulheres ainda experimentam sentimentos dúbios em relação a suas experiências profissionais, por um lado caracterizado pelo sentimento de sucesso, apesar das condições inóspitas, por outro lado a expectativa de ser aceita, valorizada e respeitada como mulher. Há nos relatos das experiências de mulheres a clara indicação do sentimento de ser diferente. Em determinados momentos superior e em outros, inferior aos homens, mas nunca iguais. ${ }^{142}$

A segregação vertical fica ainda mais patente quando pessoas que mudaram sua identidade de gênero relatam consequências benéficas no local de trabalho. A este título, Cordelia Fine cita o exemplo de um professor da Stanford University: segundo ele, pouco depois de ter se tornado homem, ouviu de colegas de trabalho elogios dizendo que seu trabalho era "bem melhor que de sua irmã". A autora menciona também a narrativa de um advogado que ouviu um colega de equipe elogiar o chefe por ter "se livrado de Susan", que ele considerava incompetente, e ter contratado “o novo cara”. Estes casos, nos quais obviamente a transgeneridade não chegava ao conhecimento dos colegas, o que poderia ocasionar ainda mais preconceito, permitem vislumbrar a "possibilidade de que os talentos de uma pessoa no local de trabalho sejam mais fáceis de ser reconhecidos quando essa pessoa é do sexo masculino". ${ }^{143}$

Portanto, a segregação das mulheres, seja em determinadas profissões ou em cargos hierarquicamente inferiores na organização produtiva, provoca a criação de guetos de atuação feminina. Consequentemente, concentradas em tipos específicos de trabalho, os riscos a que estão expostas diferem daqueles que afligem aos homens, alocados na prestação de outros serviços ou em posições de superior hierarquia. Ademais, a desvalorização do trabalho doméstico não remunerado desempenhado pelas mulheres faz com que sejam ignorados seus reflexos sobre sua saúde física e mental, de modo que não apenas a carga de obrigações suportada por elas é invisibilizada, mas também todos os danos gerados por essa carga no organismo.

A própria OIT reconhece que "a segregação por profissão leva a que a exposição aos riscos de saúde e aos perigos particulares dessa profissão afete mais o sexo supra representado do que o outro”. Como exemplos, cita a concentração de mulheres nas fábricas de zonas francas industriais de exportação, expostas a longas

\footnotetext{
${ }^{142}$ SILVEIRA, Nereida Salette Paulo da. Entendendo a experiência de inclusão-exclusão de mulheres em cargos de alta gerência. In: XXXIII Encontro da Associação Nacional de Programas de Pós-graduação e Pesquisa em Administração, 2009, São Paulo. Anais do EnANPAD 2009. Rio de Janeiro: ANPAD, 2009. 14p. p. 12.

${ }^{143}$ FINE, Cordelia. Homens não são de Marte, mulheres não são de Vênus: como a nossa mente, a sociedade e o neurossexismo criam a diferença entre os sexos. São Paulo: Cultrix, 2012. p. 87-88.
} 
durações de trabalho em postos não ergonômicos e à desproteção das máquinas, e nas indústrias de microeletrônica, expostas a produtos químicos com efeitos cancerígenos. Do mesmo modo, afirma que setores dominados por homens, como a construção civil e a indústria petrolífera, também representam perigos específicos para a força de trabalho masculina. $^{144}$

A diferente exposição de homens e mulheres a riscos laborais devido à segregação ocupacional foi constatada no quinto Inquérito Europeu sobre as Condições de Trabalho, pesquisa realizada em 2010, com 44 mil trabalhadores e trabalhadoras de 34 países da região. Por exemplo, 33\% dos homens, mas apenas $10 \%$ das mulheres estão regularmente expostos a vibrações, bem como $42 \%$ dos homens, mas $24 \%$ das mulheres transportam cargas pesadas. Em contraste, 13\% das mulheres, mas apenas 5\% dos homens levantam ou deslocam pessoas no âmbito do seu trabalho. Porcentagens semelhantes de homens e mulheres trabalham em posições que provocam cansaço ( $48 \%$ e $45 \%$, respectivamente), ou fazem movimentos repetitivos com as mãos ou os braços (64\% e 63\%, respectivamente), que são também os riscos físicos mais comuns. ${ }^{145}$

Cartilha editada pelo governo da Espanha sobre saúde laboral, ao tratar da questão, relata que os riscos mais frequentes nas atividades desenvolvidas predominantemente por mulheres são aqueles relacionados a posturas inadequadas, longas jornadas em pé e trabalho repetitivo, enquanto os riscos decorrentes dos trabalhos majoritariamente ocupados por homens são os relacionados à segurança e à manipulação de objetos pesados. Em termos gerais, resume suas constatações afirmando que, se os homens são maioria em trabalhos da construção e da indústria, "los riesgos de seguridad e higiene estarán más presentes en sus entornos de trabajo", enquanto que se as mulheres concentram-se em atividades de serviço, estão expostas, principalmente, " $a$ los riesgos ergonómicos, psicosociales y también higiénicos". ${ }^{146}$

Desse modo, a segregação ocupacional por gênero é um dos elementos chave para explicar a desigual distribuição da exposição a riscos laborais: a segregação

\footnotetext{
144 ORGANIZAÇÃO INTERNACIONAL DO TRABALHO. $O$ ABC dos direitos das mulheres trabalhadoras e da igualdade de género. Genebra: OIT, 2007. p. 176.

${ }^{145}$ FUNDAÇÃO EUROPEIA PARA A MELHORIA DAS CONDIÇÕES DE VIDA E DE TRABALHO. Quinto Inquérito Europeu sobre as Condições de Trabalho. União Europeia: Eurofound, 2010. Disponível em <http://www.eurofound.europa.eu/surveys/ewcs/2010/physicalfactors_pt.htm>. Acesso em: 20.ago.2014.

${ }^{146}$ ESPAÑA. Herramienta de apoyo $\mathrm{n}^{\circ}$ 10: Salud y riesgos laborales con perspectiva de género. Madrid: Ministerio de Sanidad, Servicios Sociales e Igualdad, 2010. Disponível em: <http://www.igualdadenlaempresa.es/recursos/herramientas/home.htm>. Acesso em: 20.ago.2014. p.7.
} 
horizontal condiciona o tipo de exposição a que mulheres e homens estão submetidos de acordo com o segmento profissional no qual se concentram; já a segregação vertical acentua as jornadas estendidas de trabalho das mulheres que combinam atividades profissionais às responsabilidades domésticas, expondo-as à sobrecarga física e mental devido à falta de descanso e ao desgaste cotidiano.

\subsubsection{O pesado "trabalho leve" feminino}

Como visto, o processo de segregação profissional envolve a desvalorização do trabalho feminino e a desqualificação das competências das mulheres, uma vez que as tarefas a elas atribuídas são normalmente consideradas extensões das práticas de cuidado e avaliadas como banais e leves, por supostamente exigirem pouco esforço físico e mental das mulheres, que as exercem de maneira "instintiva". No entanto, uma vez que docilidade, destreza, minúcia etc. são produtos da socialização, os mitos sobre as habilidades naturais femininas servem apenas para justificar a exploração no local de trabalho, o que aumenta os riscos aos quais as mulheres são expostas, vez que possíveis efeitos deletérios de seu trabalho são ocultados ou minimizados.

As novas configurações da divisão sexual do trabalho reservam para as mulheres áreas de trabalho intensivo no mundo fabril, com níveis ainda mais elevados de exploração, enquanto que as áreas dotadas de maior desenvolvimento tecnológico, caracterizadas como de capital intensivo, permanecem reservadas aos homens. ${ }^{147}$ Conforme Lorena Holzmann da Silva, a grande maioria das mulheres está alocada em ocupações de baixa remuneração, consideradas semi ou não qualificadas, desempenhando tarefas fragmentadas e repetitivas aprendidas no próprio local de trabalho, ou tarefas que demandam habilidades manuais. ${ }^{148}$

A autora afirma que, apesar de as próprias trabalhadoras reproduzirem a lógica sexista e optarem por empregos "femininos", os grandes responsáveis por essa alocação são os empregadores e setores de recursos humanos. Nas empresas por ela pesquisadas, os chefes de setor de recrutamento e seleção cultivam a concepção da

\footnotetext{
${ }^{147}$ ANTUNES, Ricardo. Os sentidos do trabalho: ensaio sobre a afirmação e a negação do trabalho. São Paulo: Boitempo, 2009. p. 108.

${ }^{148}$ SILVA, Lorena Holzmann da. Admitimos mulheres, para trabalhos leves. Estudos Feministas, Florianópolis, v. 3, n. 2, p. 349-361, 1995. p. 351-352.
} 
existência de aptidões naturalmente femininas, o que orienta a seleção das candidatas. Baseados nesta crença, o recrutamento separa "trabalho de homem" e "trabalho de mulher" dentro da fábrica, o que limita os espaços para alocação de força de trabalho feminina. Nesse sentido,

(...) a preferência por trabalhadores de um ou outro sexo é justificada com argumentos nos quais aparece frequentemente a necessidade de força física e o caráter pesado das tarefas para as quais se admitem homens, em contrapartida as tarefas consideradas leves, de detalhe e mais minuciosas mais apropriadas para as mulheres. (...) Nas indústrias de confecção, às mulheres são atribuídas tarefas de costura, revisão de acabamento, etiquetagem, podendo às vezes serem cortadoras de tecido. Os homens são cortadores de couro, modelistas, operadores de prensas. Na indústria da alimentação e do fumo, as mulheres são operadoras de máquinas e empacotadoras e os homens alimentadores das máquinas, operando algumas delas quando o tipo de operação exigida não pode ser executada por mulheres por ser considerada muito pesada. (...) Evidencia-se assim a existência da divisão sexual do trabalho dentro da fábrica, apoiada nas ideias vigentes da existência de aptidões e capacidades naturais diferenciadas para homens e mulheres. ${ }^{149}$

Dessa forma, percebe-se no mundo do trabalho a divisão entre "serviço de homem" e "serviço de mulher", sendo o manuseio de peso utilizado na afirmação da lógica binária do "pesado-difícil" contra o "leve-fácil", de modo a subestimar o esforço físico feminino e valorizar o masculino. ${ }^{150}$ Nessa lógica, "a virilidade é associada ao trabalho pesado, penoso, sujo, insalubre, algumas vezes perigoso, trabalho que requer coragem e determinação", enquanto a feminilidade é associada "ao trabalho leve, fácil, limpo, que exige paciência e minúcia". ${ }^{151}$

No entanto, o primeiro ponto a se destacar é que a noção de "trabalho leve" muitas vezes é usada estritamente para desvalorizar o trabalho realizado pelas mulheres, sem levar em conta a realidade da tarefa executada. Exemplo emblemático desse uso foi dado em pesquisa feita no Sertão de Paraíba, no Brejo da Paraíba e no Sul de Santa Catarina. Apesar de as regiões serem distintas, bem como as culturas, o traço comum entre elas era a distinção entre trabalho leve, atribuição de mulheres e crianças,

\footnotetext{
149 SILVA, Lorena Holzmann da. Admitimos mulheres, para trabalhos leves. Estudos Feministas, Florianópolis, v. 3, n. 2, p. 349-361, 1995. p. 355.

150 MARCONDES, Willer Baumgartem; ROTENBERG, Lúcia; PORTELA, Luciana Fernandes; MORENO, Claudia Roberta de Castro. O peso do trabalho "leve" feminino à saúde. São Paulo em Perspectiva, São Paulo, v. 17, n. 2, p. 91-101, abr./jun. 2003. p. 99.

${ }^{151}$ HIRATA, Helena. Divisão-relações sociais de sexo e do trabalho: contribuições à discussão sobre o conceito de trabalho. Em aberto, Brasília, ano 15, n. 65, jan./mar.1995.
} 
e trabalho pesado, incumbência masculina. Como o sustento da casa cabia aos maridos, as mulheres não precisavam trabalhar o ano todo, realizando alguns serviços para complementação da renda. Por não desempenharem o trabalho destinado aos homens, dito "pesado", justificavam-se remunerações menores ao trabalho feminino, o que poderia fazer pensar que as

(...) mulheres e crianças desempenham certas tarefas porque, de fato, estas são "leves" por sua própria natureza. Mas não é bem assim. $\mathrm{Na}$ verdade, qualifica-se o trabalho em função de quem o realiza: são "leves" as atividades que se prestam à execução por mão de obra feminina e infantil. Importa destacar que essa classificação está associada a diferentes remunerações: maior para o trabalho "pesado", menor para o "leve", mesmo que ambos demandem o mesmo número de horas ou que o esforço físico exigido por um tenha como contraponto a habilidade, a paciência e a rapidez requeridas pelo outro. O que determina o valor da diária é, em suma, o sexo de quem a recebe. (...) A falácia da "naturalidade" da distinção entre trabalho "leve" e "pesado" salta aos olhos ao constatarmos a variação que sofre conforme o lugar. No sertão, as mulheres consideravam "pesado" o que no brejo era "leve" (a capina das áreas de lavoura, por exemplo). ${ }^{152}$

O caso relatado, como muitos outros, demonstra que "trabalho leve" não significa trabalho menos estafante, demandante de menor esforço ou pouco nocivo à saúde. Na verdade, o trabalho é considerado "leve" não por suas características, mas pelo sexo de quem predominantemente o realiza. Assim, os serviços com maioria de força de trabalho feminina são relegados a um caráter secundário, o que se reflete em menor prestígio e no pagamento de remuneração mais baixa.

O segundo ponto relevante entre as consequências da taxação de determinadas atividades como "trabalho leve" é que o termo torna invisíveis os esforços físicos exigidos nestes tipos de trabalho, valorizando apenas a mensuração absoluta das cargas. Assim, é preciso considerar que apesar de as profissões masculinas exigirem tração ou levantamento de peso, o trabalho muscular é intenso, mas esporádico, diferente dos trabalhos femininos que exigem esforços físicos moderados, mas contínuos. ${ }^{153}$ Nesse sentido,

(...) o peso do trabalho "leve" adquire visibilidade se se articular a perspectiva de gênero com a abordagem ergonômica dos postos de trabalho, de modo que se contextualize esses valores de leveza e peso.

\footnotetext{
${ }^{152}$ PAULILO, Maria Ignez S. O peso do trabalho leve. Revista Ciência Hoje, n. 28, 1987.

153 MARCONDES, Willer Baumgartem; ROTENBERG, Lúcia; PORTELA, Luciana Fernandes; MORENO, Claudia Roberta de Castro. O peso do trabalho "leve" feminino à saúde. São Paulo em Perspectiva, São Paulo, v. 17, n. 2, p. 91-101, abr./jun. 2003. p. 99.
} 
Dessa forma, podemos levar em consideração não só o peso em si que o trabalhador precisa deslocar, mas as demais condições que compõem determinada atividade. Por exemplo, nos postos mais mecanizados, considerados "leves" em razão da presença da máquina e onde geralmente se alocam as mulheres, ocorrem esforços físicos que podem passar despercebidos, tais como a adoção de posturas desfavoráveis para músculos e ossos, sua manutenção por longos períodos, a repetição sucessiva dos mesmos movimentos e, somandose a estas, a pouca ou nenhuma possibilidade de sair do posto de trabalho e se locomover a fim de alternar movimentos ou, simplesmente, "dar uma esticada" para romper com o sedentarismo. ${ }^{154}$

Desse modo, em muitos casos, a somatória dos esforços realizados durante a jornada de trabalho das mulheres é maior que os esforços empreendidos na atividade masculina, para os quais a legislação determina limitação da carga. Surge, então, o questionamento acerca das restrições legislativas ao trabalho feminino, que justificadas pela suposta necessidade de resguardo do organismo feminino mais frágil, proíbem as mulheres de executar tarefas que demandem uso de força muscular superior a 20kg (artigo 390 da CLT), mas ignoram o desgaste físico das tarefas que exigem atenção, paciência, movimentos finos e intenso ritmo, causadoras de grande fadiga e graves danos à saúde, debate que aprofundaremos no capítulo $4 .{ }^{155}$

O último ponto que entendemos necessário abordar a este respeito é a impossibilidade de analisar os aspectos físicos do trabalho das mulheres sem considerar que, além de o "trabalho leve" esconder a execução de tarefas pesadas, este peso aumenta ainda mais devido às responsabilidades domésticas vinculadas às mulheres, que, como já analisado, encerram sua jornada de trabalho produtivo para iniciar a jornada de trabalho doméstico. ${ }^{156} \mathrm{~A}$ interação entre os trabalhos remunerado $\mathrm{e}$ doméstico "pode ser um aspecto-chave na compreensão do impacto diferenciado das condições de trabalho sobre a saúde de homens e mulheres". 157

\footnotetext{
${ }^{154}$ MARCONDES, Willer Baumgartem; ROTENBERG, Lúcia; PORTELA, Luciana Fernandes; MORENO, Claudia Roberta de Castro. O peso do trabalho "leve" feminino à saúde. São Paulo em Perspectiva, São Paulo, v. 17, n. 2, p. 91-101, abr./jun. 2003. p. 99.

${ }^{155}$ BARRETO, Margarida. O trabalho engendrando doenças e diferenças. In: BARRETO, Margarida; CARLOTO, Cássia Maria; COSTA, Maria Luiza da. Saúde das Trabalhadoras. São Paulo: SOF Sempreviva Organização Feminista, 1998. p. 59-79. p.63.

156 MARCONDES, Willer Baumgartem; ROTENBERG, Lúcia; PORTELA, Luciana Fernandes; MORENO, Claudia Roberta de Castro, op. cit., p. 99.

${ }^{157}$ VIDAL, Renata de Queiroz Santana; NETO, Annibal Muiz Silvany. Trabalhadoras brasileiras: características socioeconômicas e ocupacionais e perfil de saúde, Brasil, 2003. Revista Brasileira de Saúde Ocupacional, São Paulo, v. 34, n. 120, p. 115-127, jul/dez.2009. p. 124.
} 
Interessante citarmos, a título de exemplo, pesquisa de 2001 com trabalhadoras e trabalhadores do período noturno constatando que os papéis socialmente atribuídos a homens e mulheres envolvem diferentes fatores de risco à saúde, pois a maneira como lidam com o trabalho noturno não é igual: observou-se nas trabalhadoras mães a tendência a dormir menos de manhã e dormir mais vezes ao dia, quando comparadas às colegas sem filhos ou filhas; porém, não se observou diferença significativa entre os homens com e sem descendentes. A compreensão do impacto do trabalho noturno sobre as mulheres só é possível por meio da perspectiva de gênero, a partir da qual é possível verificar a necessidade de ações de compartilhamento do cuidado das crianças. ${ }^{158}$

A percepção do tempo como elemento organizador da vida na sociedade faz-se útil, neste momento, pois permite visualizar as imbricações entre trabalho remunerado e trabalho doméstico não remunerado. Por interferir de maneiras diferentes no tempo de trabalhadoras e trabalhadores, a divisão sexual do trabalho "pode ter implicações diferenciadas na saúde de homens e mulheres em termos de maior ou menor margem de tolerância ao meio". 159

Portanto, os estereótipos sexuados criam obstáculos à promoção da saúde e segurança das trabalhadoras e trabalhadores, uma vez que, ao mesmo tempo em que a segregação ocupacional por sexo interfere nas diferentes formas de exposição ao risco labor-ambiental, a divisão entre trabalhos "de mulher" ou "de homem", trabalhos "leves" ou "pesados", minimiza, e muitas vezes oculta, a própria exposição ao risco, de modo que a culpa pelo sofrimento das mulheres no trabalho recai sobre as próprias trabalhadoras e supostas fragilidades individuais, e não sobre as formas de organização e divisão sexual do trabalho.

\subsubsection{A predominância dos trabalhos precários entre as mulheres}

Desde os anos 1980, quando a flexibilização e precarização do trabalho foram intensificadas pelo neoliberalismo, é possível verificar o caráter sexuado desse

\footnotetext{
158 ROTEMBERG, Lúcia; PORTELA, Luciana Fernandes; MARCONDES, Willer Baumgartem; MORENO, Cláudia; NASCIMENTO, Cristiano de Paula. Gênero e trabalho noturno: sono, cotidiano e vivência de quem troca a noite pelo dia. Cadernos de Saúde Pública, Rio de Janeiro, n. 17, v. 3, p. 639649, 2001. p. 640-648

${ }^{159}$ BRITO, Jussara Cruz de; NEVES, Mary Yale; OLIVEIRA, Simone Santos; ROTENBERG, Lucia. Saúde, subjetividade e trabalho: o enfoque clínico e de gênero. Revista Brasileira de Saúde Ocupacional, São Paulo, v. 37, n. 126, p. 316-329, 2012. p. 326-327.
} 
processo. Isso porque, o crescimento da participação das mulheres no mercado de trabalho ocorreu, em sua maioria, em trabalhos precários e vulneráveis, especialmente naqueles em regime de tempo parcial (part-time), "marcados por uma informalidade ainda mais forte, com desníveis salariais ainda mais acentuados em relação aos homens". 160

Com o passar das décadas, conforme analisa Ricardo Antunes, assistimos à reestruturação do capital e à sua consequente crise, do que decorre o agravamento das condições de trabalho no mundo, especialmente no sentido de fazer da precarização a regra, não mais a exceção. Assim, "a terceirização e a informalidade da força de trabalho vêm se constituindo como mecanismos centrais, implementados pela engenharia do capital, para aumentar a exploração do trabalho, valorizando o capital", que quanto mais intensificados, maior é o movimento propulsor da precarização estrutural do trabalho. ${ }^{161}$

A forma mais perversa com que a precarização atinge o emprego feminino está centrada na flexibilidade imposta pelas novas formas de organização do trabalho: enquanto a flexibilidade interna, que envolve a integração de tarefas e polivalência toyotistas, está ligada à força de trabalho de masculina, a flexibilidade externa recorre à força de trabalho feminina, ou seja, empregos precários, trabalho em tempo parcial, horários flexíveis etc. Essa nova forma de divisão sexual é socialmente legitimada em nome da conciliação entre vida familiar e vida profissional que o "trabalho flexível" oferece às mulheres. Do mesmo modo, a diferença salarial continua a ser justificada com o argumento de que o salário é "renda complementar". ${ }^{162}$

Desse modo, conforme Heleieth Saffioti, o setor informal do mercado de trabalho apresenta-se como solução para as mulheres com a necessidade de conjugação de afazeres domésticos a uma ocupação que lhes traga renda, uma vez que existe maior grau de compatibilidade entre os serviços prestados de modo precário e a jornada doméstica de trabalho. Dentro dessa lógica, a atividade central das mulheres continua

\footnotetext{
${ }^{160}$ ANTUNES, Ricardo. Os sentidos do trabalho: ensaio sobre a afirmação e a negação do trabalho. São Paulo: Boitempo, 2009. p. 108.

${ }^{161}$ Id., A corrosão do trabalho e a precarização estrutural. In: LOURENÇO, Edvânia Ângela De Souza; NAVARRO, Vera Lucia (orgs.). O avesso do trabalho III: saúde do trabalhador e questões contemporâneas. São Paulo: Outras expressões, 2013. p. 22-27. p. 22.

${ }^{162}$ HIRATA, Helena; CATTANÉO, Nathalie. Flexibilidade. In: HIRATA, Helena; LABORIE, Françoise; LE DOARÉ, Hélène; SENOTIER, Danièle (org.). Dicionário Crítico do Feminismo. São Paulo: Editora Unesp, 2009. p. 106-111.
} 
sendo a reprodução, enquanto o trabalho remunerado resta dependente das pressões e obrigações familiares. ${ }^{163}$

Nesse sentido, ao elencarem as características da já mencionada "nova divisão sexual do trabalho", Helena Hirata e Danièle Kergoat descrevem o surgimento de nomadismos sexuados, derivados da precarização e flexibilização do emprego: nomadismo no tempo, reservado às mulheres, que é expansão do trabalho em tempo parcial ou em domicílio; e o nomadismo no espaço, para os homens, verificado nos trabalhos que exigem deslocamento profissional e maior tempo fora de casa. Observase, assim, que a flexibilização se utiliza e reforça as relações de gênero, designando às mulheres os trabalhos em que lhes sobre mais tempo para dedicarem à família. ${ }^{164}$

De modo semelhante, a precarização do trabalho masculino também utiliza como apoio a divisão sexual do trabalho, pois envolve, majoritariamente, postos de trabalho informais ou terceirizados que exigem mobilidade e disponibilidade do trabalhador, variáveis de acordo com a demanda da produção. Tal disponibilidade temporal e espacial dos homens só é possível porque mulheres asseguram a gestão das tarefas domésticas e afetivas da família. ${ }^{165}$

A precarização é visível em países do norte na figura do trabalho em tempo parcial e nos países do sul, no trabalho informal. Ambos, ocupados majoritariamente por mulheres, são trabalhos instáveis, mal remunerados, sem perspectivas de formação ou promoção e com direitos sociais limitados ou inexistentes. ${ }^{166}$ No caso brasileiro, essa realidade é descrita nos dados sobre a estrutura do mercado de trabalho: entre os homens ocupados, $42,5 \%$ são empregados com carteira assinada e $25,4 \%$ trabalhadores por conta-própria, o que representa mais de $60 \%$ da população ocupada masculina; já no caso das mulheres, a população ocupada está mais concentrada em trabalhos precários, que representam cerca de $37 \%$ dessa população, no

\footnotetext{
${ }^{163}$ SAFFIOTI, Heleieth Iara. Força de Trabalho feminina no Brasil: no interior das cifras. Perspectivas, São Paulo. v. 8, p. 95-141, 1985. p. 129-131.

164 HIRATA, Helena; KERGOAT, Danièle. Novas configurações da divisão sexual do trabalho. Cadernos de Pesquisa. V. 37, n. 132, p. 595-609, set./dez.2007. p. 600.

165 THÉBAUD MONY, Annie. Saúde no trabalho. In: HIRATA, Helena; LABORIE, Françoise; LE DOARÉ, Hélène; SENOTIER, Danièle (org.). Dicionário Crítico do Feminismo. São Paulo: Editora Unesp, 2009. p. 217-222.

${ }^{166}$ HIRATA, Helena. Globalização e divisão sexual do trabalho. Cadernos Pagu, Campinas, n. 17-18, p. 139-156, 2002. p. 145
} 
que se incluem empregadas sem carteira (11,9\%), trabalhadoras domésticas $(15,5 \%)$, produtoras para o próprio consumo $(5,1 \%)$ e trabalhadoras não remuneradas $(4,4 \%) .{ }^{167}$

Diante dessa realidade, percebemos que, apesar de a deterioração das relações de trabalho gerar reflexos sobre todos os trabalhadores e trabalhadoras, sobre elas incide de maneira mais aguda, uma vez que se somam e potencializam as relações de gênero já anteriormente dominantes. Contribuem, portanto, para manter na invisibilidade as consequências do trabalho, especialmente do trabalho precário sobre a saúde e a segurança das mulheres, tanto na esfera produtiva quanto reprodutiva.

Como exemplo da relação danosa à saúde das mulheres quando conjugados os fatores gênero e trabalho precário, citamos o estudo realizado pelo Centro de Estudos de Saúde do Trabalhador e Ecologia Humana (Ceteh/Ensp/Fiocruz) com trabalhadoras terceirizadas da lavanderia de uma indústria do setor químico, cuja função principal era lavar roupa de operários da produção que manipulam mercúrio metálico. Sob o viés de gênero, o trabalho de lavanderia realizado por essas mulheres era desvalorizado, pois compreendido como desqualificado e "leve", apesar de tratar-se de trabalho repetitivo, que exige grande esforço físico e que as expõem a fatores como mercúrio, calor e ruído. Consequentemente, as trabalhadoras recebiam baixos salários e não tinham reconhecimento, ficando isoladas do restante da fábrica.

Sob o viés da precarização, essas trabalhadoras eram terceirizadas, o que significa que não tinham direitos como filiação ao Sindicato dos Químicos, ao almoço no refeitório da empresa e ao convênio médico. De forma combinada, relatou-se a desigualdade dos cuidados dirigidos a elas em comparação com aqueles oferecidos aos trabalhadores homens da indústria, no que se inclui a menor constância de exames laboratoriais sobre as condições de saúde dessas trabalhadoras, expostas de modo semelhante aos riscos de contaminação com vapor de mercúrio. Segundo o estudo,

(...) a saúde dessas trabalhadoras, sob o ponto de vista do coletivo, é atingida, não só pelas condições materiais inadequadas, que as expõem a riscos particulares, mas também por um conjunto de fatores ligados à organização do trabalho, que as colocam numa posição desfavorecida, precária, como menos controle sobre sua saúde e menor possibilidade de reivindicar, questões geradas pela identidade de gênero. ${ }^{168}$

\footnotetext{
167 BRASIL. Relatório Anual Socioeconômico da Mulher. Brasília: Secretaria de Políticas para as Mulheres, 2013. p. 44.

${ }^{168}$ BRITO, Jussara C. de; MATTOS, Ubirajara; SOARES, Vanda D’A.; FERREIRA, Heloisa P. Saúde das trabalhadoras: o caso da lavanderia de uma indústria química de cloro-soda. Cadernos de Saúde Pública, Rio de Janeiro, v. 11, n. 4, p. 543-551, out/dez 1995. p. 550.
} 
Desse modo, o processo de precarização do trabalho faz questionar sobre a capacidade de o ordenamento jurídico conseguir atingir esses trabalhadores e trabalhadoras que laboram expostos a condições de trabalho mais degradantes e, muitas vezes, mais perigosas e insalubres, excluídos da proteção social e, até mesmo, das estatísticas acidentárias. Muito mais que em atividades formais, os riscos do trabalho precarizado e suas consequências seguem invisíveis, de modo que o adoecimento é tratado como fato privado de cada indivíduo, e sua gestão é assumida pelas mulheres dentro do espaço domestico, sejam pais, filhos, maridos ou elas mesmas. ${ }^{169}$

Por fim, ao constatar que os lugares encontrados pelas mulheres no mercado de trabalho ainda trazem a marca da desigualdade - o que pode ser observado "na presença feminina significativa no trabalho informal, no trabalho em domicílio, nas atividades em tempo parcial, na 'guetização' das mulheres no mercado de trabalho" e nas taxas de desemprego feminino ${ }^{170}$-, não há como negar a influência dessa realidade sobre a exposição das trabalhadoras a riscos ocupacionais.

\subsection{Uso da categoria gênero no estudo da saúde e segurança do trabalho}

Ao longo deste capítulo verificamos que trabalhadoras e trabalhadores se distinguem não apenas biológica, mas também socialmente, por meio de fatores condicionantes do modo de inserção no mercado de trabalho e das condições de prestação de sua atividade, o que interfere diretamente na saúde e segurança laborais. Essa perspectiva permite constatar o caráter sistêmico do meio ambiente do trabalho, uma vez que seu equilíbrio depende da relação de interdependência entre todos os fatores que interagem ambientalmente, sejam eles materiais, como temperatura, agentes químicos, máquinas e instrumentos, ou imateriais, como as relações sociais de sexo e demais fatores de discriminação.

Dessa maneira, utilizar o gênero como categoria analítica da relação entre saúde e trabalho, determinada pelos papéis sociais desempenhados por cada sexo, revela

\footnotetext{
${ }^{169}$ APPAY, Béatrice; THÉBAUD-MONY, Annie. Precarização social. In: HIRATA, Helena; LABORIE, Françoise; LE DOARÉ, Hélène; SENOTIER, Danièle (org.). Dicionário Crítico do Feminismo. São Paulo: Editora Unesp, 2009. p. 193-198.

${ }^{170}$ BERTOLIN, Patrícia Tuma Martins; CARVALHO, Suzete. A segregação ocupacional da mulher: será a igualdade jurídica suficiente para superá-la? In: BERTOLIN, Patrícia Tuma Martins; ANDREUCCI, Ana Claudia Pompeu Torezan (org). Mulher, sociedade e direitos humanos. São Paulo: Rideel, 2010. p. 179-210. p. 191.
} 
os motivos de o trabalho repercutir de modos diferentes nos organismos de homens e mulheres. Possibilita incorporar dimensões como a sensibilidade e a subjetividade, por muito tempo ignoradas, que revelam a capacidade de trabalhadores e trabalhadoras "perceberem diferentemente as agressões sociais, vindo a constituir o adoecer um grito de alerta e denúncia da relação hierárquica de poder entre os gêneros no local de trabalho". ${ }^{171}$

Vale destacar a existência de um processo de seletividade do risco, que é prioritariamente determinado "por aqueles que possuem os meios de produção, levandose em conta os componentes ambientais (...), a performance do trabalho e as próprias relações humanas estabelecidas no local de trabalho". Desse modo, os riscos laborambientais estão associados à tomada de medidas de proteção pelos empregadores, as quais são direcionadas de formas diferentes para determinados setores da sociedade, deixando outros a suportar cargas de substâncias nocivas com maior regularidade. Por conseguinte, segundo Júlio Cesar de Sá da Rocha, "a exposição ao risco assume significado completamente diferente para pessoas diferentes, de acordo com o tipo de trabalho, a informação, educação, e camada social”, bem como o sexo e a raça. ${ }^{172}$

Consequência da divisão sexual do trabalho, que concentra mulheres em tarefas que exigem destreza manual, atenção e paciência, e homens em funções de responsabilidade e no trabalho "pesado", o perfil de patologias entre os sexos é distinto: enquanto entre os trabalhadores há maior ocorrência de acidentes traumáticos, como contusões e amputações ${ }^{173}$, as trabalhadoras sofrem mais com estresse, lesões por esforços repetitivos e depressão. No entanto, a relação de causalidade entre o sofrimento feminino e o trabalho permanece, muitas vezes, invisível, pois a saúde das mulheres é culturalmente ligada apenas à reprodução e à sexualidade, desvinculada do trabalho, tendo como desdobramento a ausência de medidas efetivas de proteção.

A invisibilidade das doenças frente aos acidentes de trabalho decorre, justamente, da atenção focada aos grandes perigos e aos visíveis danos à saúde física, normalmente vinculados a profissões masculinas, em detrimento dos riscos de

\footnotetext{
${ }^{171}$ OLIVEIRA, Eleonora Menicucci de. Corpos saudáveis e corpos doentes na nova organização social do trabalho. In: ROCHA, Maria Isabel Baltar da. (org). Trabalho e Gênero: Mudanças, Permanências e Desafios. São Paulo: Editora 34, 2000. p. 237-256.

${ }^{172}$ ROCHA, Júlio Cesar de Sá da. Direito ambiental do trabalho. São Paulo: LTr, 2002. p. 134-135.

${ }^{173}$ No caso dos homens, o fato de a sociedade sexista exigir deles virilidade e bravura faz com que aceitem, sem poderem demonstrar temor, trabalhos perigosos, que oferecem riscos de acidentes graves decorrentes de quedas, esforço físico demasiado ou exposição à eletricidade e materiais tóxicos.
} 
adoecimento decorrentes das ocupações predominantemente femininas, conforme constatado pela OIT, na publicação comemorativa do Dia Mundial da Segurança e Saúde no Trabalho de 2013:

As doenças profissionais, ou relacionadas com a atividade profissional, são fonte de extremo sofrimento e perdas no mundo do trabalho. Contudo, ainda que sejam anualmente responsáveis pela morte de seis vezes mais pessoas do que os acidentes de trabalho, permanecem em grande medida invisíveis. Além disso, a natureza destas doenças está a mudar rapidamente: as mudanças tecnológicas e sociais, aliadas às condições da economia mundial, agravam os atuais perigos para a saúde e geram novos fatores de risco. As doenças profissionais bem conhecidas, tais como as pneumoconioses, permanecem um fenômeno generalizado, enquanto as relativamente novas, como as perturbações mentais e musculoesqueléticas (PME), são cada vez mais frequentes. ${ }^{174}$

Nesse sentido, Margarida Barreto afirma que o olhar de gênero "possibilita compreender a relação saúde/doença de uma nova forma, permitindo visualizar na desigualdade sexual e social as manifestações diferentes do adoecer". Assim, a solução para o adoecimento das mulheres relacionado às condições de trabalho não pode centrar-se na proibição do emprego de trabalhadoras em determinadas atividades ou funções, atitude que apenas reforça a discriminação, sem combater os riscos e os agentes nocivos presentes no ambiente laboral. É necessário, então, que seja rompida a lógica de assimetria de direitos entre homens e mulheres, baseada em justificativas de cunho biologicistas, pois esta visão transforma as "diferenças biológicas (ciclo menstrual, gestação e aleitamento) em desigualdades que justificam as diferenças salariais das mulheres quando comparadas à mesma função dos homens". ${ }^{175}$

Portanto, o presente estudo parte da premissa de que as relações de gênero determinam formas sexuadas de trabalho, o que gera como consequência uma distinção nos quadros patológicos e de insegurança para homens e mulheres ${ }^{176}$, com o objetivo de combater a naturalização das diferenças entre os sexos que fundamenta a desigualdade. Contudo, o enfoque de gênero é praticamente ausente nas normas

\footnotetext{
${ }^{174}$ ORGANIZAÇÃO INTERNACIONAL DO TRABALHO. A prevenção das doenças profissionais: relatório para o Dia Mundial da Segurança e Saúde no Trabalho. Genebra: OIT, 2013. p. 4.

${ }^{175}$ BARRETO, Margarida. Urge um olhar de gênero para compreender o adoecer no trabalho. In: INSTITUTO LATINOAMERICANO DE EDUCAÇÃO INTEGRAL. Um olhar de gênero na saúde e segurança no trabalho. ILEI: São Paulo, nov.2005. p. 7-10.

${ }^{176}$ PACHECO, Vanise Goulart. Gênero, saúde e trabalho: fatores que interagem no desenvolvimento de LER em trabalhadores telefônicos. Dissertação (Mestrado em Psicologia) - Faculdade de Filosofia e Ciências Humanas, Universidade Federal de Minas Gerais, Minas Gerais. Março, 2002. p. 4-5.
} 
trabalhistas, restringindo-se às determinações de não discriminação, quadro agravado quando observamos as normas de saúde e segurança: ao mesmo tempo em que muitos dispositivos subestimam as capacidades das mulheres, especialmente físicas, estão ausentes, por exemplo, normas de proteção contra doenças causadas por tarefas repetitivas e monótonas, que são majoritariamente executadas por mulheres. ${ }^{177}$

Sabemos, porém, seguindo o pensamento de Patricia Tuma Martins Bertolin e Suzete Carvalho, que "o mero reconhecimento jurídico da proibição de discriminação não será capaz de reverter" a lógica da divisão sexual do trabalho, de modo que, combater a desigualdade no que diz respeito ao trabalho feminino "não se trata apenas de aumentar a presença de mulheres no mercado de trabalho, mas de superar os espaços de segregação que as têm confinado". ${ }^{178}$

Desse modo, inserir a perspectiva de gênero no Direito do Trabalho não significa simplesmente criar mais normas de proibição de determinadas práticas discriminatórias, ainda que elas sejam de grande relevância, mas fazer com que as mulheres sejam juridicamente consideradas em suas relações com outras mulheres e com os homens, e não pela diferença, debilidade ou inferioridade. Isso vale especialmente para as normas de proteção labor-ambiental, que precisam sair do paradigma da diferenciação das mulheres pela inferioridade, criando uma nova abordagem protetiva sob o viés das relações sociais de sexo.

A necessidade de mudança de paradigma fica clara na constatação de que a identificação dos riscos labor-ambientais comete repetidamente os mesmo erros, onipresentes em todos os âmbitos da saúde, mas especialmente na legislação referente à saúde e segurança no trabalho, erros que se devem ao fato de que

(...) se considera a hombres y mujeres iguales cuando no lo son (factores fisiológicos, antropométricos, hormonales, sociales), y se considera que son diferentes en aspectos en los que en realidad son iguales (posibilidad de enfermar de patologías tradicionalmente "masculinas" -como las cardiovasculares -, exposición a riesgos, capacidad de trabajo, aptitudes técnicas, dotes de organización....). ${ }^{179}$

\footnotetext{
${ }^{177}$ MÁRQUEZ GARMENDIA, Martha. Derecho laboral: iigualdad y no discriminación? In: PENIDO, Laís de Oliveira (coord.). Igualdade dos gêneros nas relações de trabalho. Brasília: ESMPU, 2006. p. 139-144. p. 144.

${ }^{178}$ BERTOLIN, Patrícia Tuma Martins; CARVALHO, Suzete. A segregação ocupacional da mulher: será a igualdade jurídica suficiente para superá-la? In: BERTOLIN, Patrícia Tuma Martins; ANDREUCCI, Ana Claudia Pompeu Torezan (org). Mulher, sociedade e direitos humanos. São Paulo: Rideel, 2010. p. 179-210. p. 206.

${ }^{179}$ GONZÁLES GÓMEZ, Maria Fernanda. Salud laboral y género: Apuntes para la incorporación de la perspectiva de género en el ámbito de la prevención de riesgos laborales. Medicina y Seguridad del trabajo [online], v. 57, supl.1, p. 89-114, 2011. p. 97.
} 
Assim, tratar a saúde e segurança no trabalho a partir da problemática de gênero permite "desenvolver uma análise crítica da elaboração das leis e regulamentações, mas também das práticas institucionais e sindicais em saúde ocupacional". ${ }^{180}$ Conforme Eleonora Menicucci de Oliveira, o uso da categoria gênero nos estudos de saúde laboral amplia a compreensão do processo saúde-doença, introduzindo a "dimensão de poder crivada pela desigualdade sexual para explicar os diferentes impactos que a exposição aos mesmos riscos químicos, ergonômicos e psíquicos nos locais de trabalho provocam no homem e na mulher". Ademais, "reorganiza o conhecimento científico na ótica da não desqualificação pela diferença sexual". 181

Se a experiência de vivermos sob a atual legislação trabalhista, orientada para a proteção das mulheres essencialmente enquanto mães, tem demonstrado efeitos potencialmente discriminatórios no mercado de trabalho, fica patente a necessidade de reorganização dessas normas. ${ }^{182}$ Ao mesmo tempo, é preciso levar em consideração os riscos laborais também em função do gênero para uma melhor gestão e prevenção. Sob esse escopo, a Comissão Europeia publicou o documento "Adaptação às transformações do trabalho e da sociedade: uma nova estratégia comunitária de saúde e segurança 20022006", segundo o qual

(...) as ações preventivas, mas também os instrumentos de medição e as regras de compensação e indenização, devem ter em conta de modo específico a participação crescente das mulheres no mundo do trabalho, bem como os riscos em relação aos quais as mulheres apresentam maior sensibilidade. Estas ações em prol das mulheres devem basear-se em investigações sobre os aspectos ergonômicos, a concepção dos postos de trabalho, os efeitos da exposição a agentes físicos, químicos e biológicos, bem como a consideração das diferenças fisiológicas e psicológicas na organização do trabalho. ${ }^{183}$

\footnotetext{
${ }^{180}$ THÉBAUD MONY, Annie, Saúde no trabalho. In: HIRATA, Helena; LABORIE, Françoise; LE DOARÉ, Hélène; SENOTIER, Danièle (org.). Dicionário Crítico do Feminismo. São Paulo: Editora Unesp, 2009. p. 217-222.

${ }^{181}$ OLIVEIRA, Eleonora Menicucci de; BARRETO, Margarida. Engendrando gênero na compreensão das lesões por esforços repetitivos. Saúde e Sociedade [online], v. 6, n. 1, p. 77-99, 1997. p. 81-82.

182 ORGANIZAÇÃO INTERNACIONAL DO TRABALHO. O ABC dos direitos das mulheres trabalhadoras e da igualdade de género. 2 ed. Genebra: OIT, 2007. p. 176.

${ }^{183}$ COMISSÃO DAS COMUNIDADES EUROPEIAS. Adaptação às transformações do trabalho e da sociedade: uma nova estratégia comunitária de saúde e segurança 2002-2006. Bruxelas: União Europeia, 2002. Disponível em: <file://C:/Documents\%20and\%20Settings/USER/Meus\%20documentos/ Downloads/com2002_pt.pdf>. Acesso em: 15.ago.2014. p.7.
} 
A Comissão Europeia ainda propôs uma abordagem global do bem-estar no trabalho, definindo que a política comunitária de saúde e segurança no trabalho tenha como objetivo a melhoria contínua do estado de bem-estar no trabalho, em todas as dimensões, sendo necessária a integração da dimensão da igualdade entre homens e mulheres na avaliação dos riscos laborais, nas medidas de prevenção e nos dispositivos de indenização por exposição, "a fim de ter em conta as especificidades das mulheres em matéria de saúde e segurança no trabalho". ${ }^{184}$

Na mesma linha, recente publicação da OIT elencou orientações sobre as possíveis formas de abordagem da igualdade de gênero em saúde e segurança no trabalho, dentre as quais as necessidades de: avaliação crítica das investigações epidemiológicas dos riscos labor-ambientais sobre as populações profissionalmente definidas, "de modo a detectar preconceitos e a evitar presunções com base em estereótipos de gênero"; extensão da proteção legal especial para as trabalhadoras e também aos trabalhadores do sexo masculino; e incentivo para que as mulheres sejam "mais igualmente representadas em todos os processos de tomada de decisão sobre a proteção da sua saúde". ${ }^{185}$

Concluímos, portanto, pela necessidade de que as normas brasileiras sobre saúde e segurança no trabalho não sejam mais insensíveis ao gênero (gender blind), mas que absorvam o princípio da igualdade. Isso não significa impor uma "igualdade absoluta, linear ou completa" entre todas e todos. Pelo contrário, a proposta é que as pessoas sejam respeitadas em suas diferenças e na sua individualidade, de modo que não precisem e não devam ser tratadas de modo idêntico. "No fundo, não há como impedir que o legislador faça distinções", uma vez que elas são "indispensáveis para adaptar a legislação às necessidades sociais". Entretanto, interessa justamente que essas distinções estejam fundadas na igualdade de gênero, do que decorre a necessidade de eliminarmos da legislação traços remanescentes de sexismo. ${ }^{186}$

Tomando como base todo o exposto neste capítulo, pretendemos agora analisar o sistema de tutela à saúde e segurança do trabalho de homens e mulheres, na

\footnotetext{
${ }^{184}$ COMISSÃO DAS COMUNIDADES EUROPEIAS. Adaptação às transformações do trabalho e da sociedade: uma nova estratégia comunitária de saúde e segurança 2002-2006. Bruxelas: União Europeia, 2002. Disponível em: <file:///C:/Documents\%20and\%20Settings/USER/Meus\%20documentos/ Downloads/com2002_pt.pdf>. Acesso em: 15.ago.2014. p. 8-9.

185 ORGANIZAÇÃO INTERNACIONAL DO TRABALHO. O ABC dos direitos das mulheres trabalhadoras e da igualdade de género. Genebra: OIT, 2007. p. 178-179.

${ }^{186}$ MALLET, Estevão. Igualdade e discriminação em direito do trabalho. São Paulo: LTr, 2013. p. 87.
} 
tentativa de verificar de forma aprofundada como as relações de gênero estão inseridas no ordenamento jurídico brasileiro. Assim, partindo de uma análise crítica de tais normas, buscaremos entender se e como a legislação reforça a divisão sexual do trabalho, se e como influencia ou até mesmo reforça a discriminação das mulheres no mercado de trabalho, para que posteriormente possamos abordar temas caros à saúde e segurança no trabalho sob o enfoque de gênero. 


\section{Capítulo 2. Normas de saúde e segurança do trabalho das mulheres: da proibição à proteção}

\subsection{Evolução histórica}

\subsubsection{Direito Internacional}

A noção de direitos humanos e o princípio da igualdade nos remetem, atualmente, à ideia de acesso universal às condições mínimas de dignidade e cidadania, livre de qualquer tipo de discriminação. Entretanto, em sua origem, tais conceitos possuíam conotação diversa, uma vez que a Declaração dos Direitos do Homem e do Cidadão, de 1789, ao proclamar que "seres humanos nascem e permanecem iguais em direitos", tinha o objetivo de combater os privilégios medievais e garantir participação dos indivíduos na vida pública. Sendo o espaço público estritamente masculino, tais direitos eram literalmente "do Homem e do Cidadão", excluindo as mulheres do processo e da cidadania. ${ }^{187}$

Durante o século XIX, com o Direito voltado ao homem cidadão burguês, no contexto da Revolução Industrial e do liberalismo estatal, a exploração de mulheres e crianças pelos proprietários de fábricas era crescente, por serem força de trabalho mais barata e de mais fácil controle quando comparada com a masculina. A alteração desse quadro ocorre apenas com a intervenção do Estado nas relações de trabalho, por meio das primeiras leis trabalhistas, que tratavam da idade mínima para o trabalho na indústria, restrições ao emprego da força de trabalho feminina e duração diária do trabalho. ${ }^{188}$ Desse modo, a edição das primeiras normas de tutela do trabalho das mulheres coincide com o surgimento do próprio Direito do Trabalho.

Apenas após a Primeira Guerra Mundial tem início um processo de modificação no ordenamento jurídico internacional, que incorpora o ideal de isonomia entre os sexos, incorporando ao princípio da igualdade uma dupla característica: princípio formal de igualdade e regra material de não discriminação. ${ }^{189}$ Conjuntamente, em 1919, o Tratado de Versalhes funda a OIT, posteriormente incorporada à ONU,

\footnotetext{
${ }^{187}$ FONSECA, Rosa Maria Godoy Serpa da. Mulher, direito e saúde: repensando o nexo coesivo. Saúde e Sociedade, São Paulo, v. 8, n. 2, p. 3-32, 1999. p. 14.

${ }^{188}$ NASCIMENTO, Amauri Mascaro do. Iniciação ao Direito do Trabalho. São Paulo: LTR, 2000. p. 41.

${ }^{189}$ BARROS, Alice Monteiro de. A Mulher e o Direito do Trabalho. São Paulo: LTR, 1995. p. 133.
} 
órgão internacional especializado nas questões do trabalho, com representação paritária de governos dos Estados-Membros e de organizações de trabalhadores e empregadores.

No mesmo ano, a OIT edita as Convenções n. 3 e 4, ambas sobre a proteção da saúde e segurança das mulheres no trabalho. ${ }^{190}$ A Convenção 3 versou sobre a proteção à maternidade, conferindo às empregadas de estabelecimentos industriais e comerciais a licença remunerada obrigatória de seis semanas antes e depois do parto e a concessão de intervalos de 30 minutos para a amamentação (artigo $3^{\circ}$ ). ${ }^{191} \mathrm{Já}$ a Convenção 4 tratou do trabalho noturno feminino, proibindo que mulheres de qualquer idade fossem empregadas durante a noite em estabelecimento industrial, com exceção de estabelecimentos em que trabalhassem apenas os membros da família (artigo $\left.3^{\circ}\right){ }^{192}$

Na época, a OIT adotou normas sobre saúde e segurança no trabalho, como a Recomendação 6, que proibiu o fósforo branco, ${ }^{193}$ e a Convenção 18 , sobre doenças profissionais ${ }^{194}$. Dentre elas, merece destaque a Convenção 13, de 1921, sobre o uso de alvaiade na pintura, pois seu artigo $3^{\circ}$ continha expressa proibição do emprego de mulheres em trabalhos de pintura industrial que utilizassem sulfato de chumbo, cerusita ou qualquer produto com os referidos pigmentos. ${ }^{195}$ Assim, notamos que as Convenções 4 e n. 13 seguem a mesma linha de proibição do trabalho feminino em determinados serviços, como forma de proteção à sua saúde, principalmente reprodutiva.

Em 1934, a Convenção 4 foi revista pela Convenção 41, que manteve a proibição do trabalho feminino noturno em estabelecimento industrial, acrescentando às exceções as mulheres que ocupassem postos de direção e que não efetuassem normalmente trabalho manual (artigo $8^{\circ}$ ). ${ }^{196}$ De modo semelhante, a Convenção 89, de 1948, ampliou a previsão de exceções à proibição do trabalho noturno das mulheres,

\footnotetext{
${ }^{190}$ As Convenções da OIT são tratados internacionais abertos à ratificação por seus Estados Membros, enquanto as Recomendações definem diretrizes não vinculativas para orientação da política e prática nacionais. (ORGANIZAÇÃO INTERNACIONAL DO TRABALHO. O ABC dos direitos das mulheres trabalhadoras e da igualdade de género. 2 ed. Genebra: OIT, 2007. p. 6).

191 Adotada pela OIT em 1919; ratificada pelo Brasil em 26.04.1934 e denunciada em 26.07.1961.

${ }^{192}$ Adotada pela OIT em 1919; ratificada pelo Brasil em 26.04.1934 e denunciada em 15.05.1937.

193 Adotada pela OIT em 1919; não ratificada pelo Brasil.

${ }^{194}$ Adotada pela OIT em 1925; não ratificada pelo Brasil.

195 Adotada pela OIT em 1921; não ratificada pelo Brasil.

${ }^{196}$ Adotada pela OIT em 1934; ratificada pelo Brasil em 08.06.1936 e denunciada em 24.04.1957.
} 
inserindo a não aplicação das normas do convênio aos serviços ligados à higiene e bemestar $\left(\operatorname{artigo} 8^{\circ}\right)$ e por razão de interesse nacional $\left(\operatorname{artigo~} 5^{\circ}\right) .{ }^{197}$

Entrementes, foi aprovada a Convenção 45, que vedou o trabalho das mulheres de qualquer idade em trabalhos subterrâneos em minas, salvo em casos de mulheres que ocupassem cargos de direção, prestassem serviços sociais ou de saúde, que para efeitos de formação profissional realizassem atividades no subterrâneo e qualquer outra em exercício de profissão que não seja de caráter manual (artigo $3^{\circ}$ ). ${ }^{198}$

De 1944, a Declaração da Filadélfia, responsável por traçar os objetivos da OIT, dispôs em seu item II, letra a, que todos os seres humanos, independente de raça, credo ou sexo, "têm direito a perseguir seu bem estar material e seu desenvolvimento espiritual em condições de liberdade e dignidade, de segurança econômica e em igualdade de oportunidades". Em consonância, a Carta da ONU, de 1945, e a revisão da Declaração dos Direitos do Homem e do Cidadão em 1948, com o lançamento da Declaração Universal dos Direitos Humanos, conferiram uma nova concepção aos direitos humanos fundamentais, que passaram a incluir direitos econômicos, sociais e culturais, sendo relevantes para nós a igualdade de direitos entre os sexos e o direito à saúde e ao bem-estar.

Essa mudança de paradigma dos direitos humanos para as Nações Unidas teve grandes reflexos na OIT, de modo que as convenções referentes às mulheres adotadas no período tinham como objetivo o fomento da igualdade no trabalho. Assim, a Convenção 100 da OIT, ${ }^{199}$ de 1951, complementada pela Recomendação 90, tratou da igualdade de remuneração entre homens e mulheres para trabalho de igual valor. Do mesmo modo, a Convenção 111 e a Recomendação 111, de 1958, consagraram o princípio da não-discriminação no emprego e na profissão. ${ }^{200}$

No mesmo sentido, em 1952, a Convenção 3 foi revista pela Convenção 103, que estendeu o campo de aplicação das normas de tutela à maternidade às empregadas de setores não industriais, às empregadas agrícolas e domésticas e às mulheres que trabalham em domicílio. Ademais, tornou claro que os intervalos para fins

\footnotetext{
${ }^{197}$ Adotada pela OIT em 1948; ratificada pelo Brasil em 25.04.1957.

198 Adotada pela OIT em 1935; ratificada pelo Brasil em 22.09.1938.

${ }^{199}$ Adotada pela OIT em 1951; ratificada pelo Brasil em 25.04.1957.

${ }^{200}$ Convenção 111: Adotada pela OIT em 1958; ratificada pelo Brasil em 26.11.1965.
} 
de aleitamento devem ser computados na duração do trabalho e remunerados como tal $(\operatorname{artigo} \mathrm{V}) .^{201}$

Importante contribuição para a evolução do conceito de direitos humanos, o Pacto Internacional sobre Direitos Econômicos, Sociais e Culturais PIDESC, aprovado pela ONU em 1966, é instrumento internacional de proteção a tais direitos, dentre os quais o direito ao trabalho, à previdência social, à liberdade de associação sindical e à não-discriminação. Em seu artigo 12, introduz a garantia do direito de todas as pessoas de "gozar do melhor estado de saúde física e mental possível de atingir". ${ }^{202}$

O ano de 1975 foi de extrema relevância para o avanço dos direitos das mulheres. Declarado o Ano Internacional da Mulher pela Assembleia Geral da ONU, foi marcado pela primeira Conferência Mundial da Mulher, sediada na Cidade do México. A conferência proclamou os anos de 1975 a 1985 como a Década da Mulher, período em que aconteceram também as conferências mundiais sobre as mulheres de Copenhague, em 1980, e de Nairóbi, em 1985. ${ }^{203}$

Além da primeira Conferência Mundial da Mulher, foi também em 1975 que a $60^{\mathrm{a}}$ Conferência Internacional do Trabalho editou a Declaração sobre Igualdade de Oportunidade de Tratamento para as Trabalhadoras, responsável por introduzir novo paradigma à proteção normativa das trabalhadoras, que, de modo geral, passou a ser limitada aos casos de resguardo da gestante e lactante. Nesse sentido, merecem destaque os seguintes artigos, que tratam da saúde e segurança das mulheres:

Artículo $6^{\circ}$. 6. Los empleos y lugares de trabajo deberán en la medida de lo posible convenir a todos los trabajadores, tanto hombres como mujeres.

Artículo $9^{o}$. 2. Las mujeres estarán protegidas contra los riesgos inherentes a su empleo y ocupación sobre la misma base y con las mismas normas de protección que los hombres, en función de los progresos en el conocimiento científico y tecnológico.

3. Se emprenderán estudios e investigaciones relativos a las ocupaciones que puedan tener sobre mujeres y hombres efectos nocivos, por lo que respecta a su función social de reproducción. ${ }^{204}$

\footnotetext{
${ }^{201}$ Adotada pela OIT em 1952; ratificada pelo Brasil em 18.06.1965.

${ }^{202}$ PIDESC foi adotado pela Assembleia Geral da ONU em 1966 e ratificado pelo Brasil em 24.02.1992.

203 ORGANIZAÇÃO DAS NAÇÕES UNIDAS. A ONU e as mulheres. Disponível em: <http://www.onu.org.br/a-onu-em-acao/a-onu-e-as-mulheres/>. Acesso em: 28.jul.2014.

204 ORGANIZAÇÃO INTERNACIONAL DO TRABALHO. Declaración sobre la igualdad de oportunidades y de trato para las trabajadoras. Genebra: OIT, 1975. Disponível em: <http://www.ilo.org/public/libdoc/ilo/P/09648/09648(1975-A-1)104-109.pdf\#page=3>.. Acesso em: 16.ago.2014.
} 
Fruto da mesma década, a CEDAW, de 1979, representou grande avanço na pauta da proteção igualitária à saúde e segurança das trabalhadoras, pois passou a não aceitar proibições ao trabalho das mulheres baseadas na suposta proteção à sua saúde, entendendo que discriminação inclui toda forma de "distinção, exclusão ou restrição baseada no sexo" (artigo $1^{\circ}$ ). ${ }^{205}$ A CEDAW ainda determinou aos EstadosPartes a adoção de todas as medidas apropriadas para assegurar igualdade de direitos entre homens e mulheres no emprego, em particular "o direito à proteção da saúde e à segurança nas condições de trabalho, inclusive a salvaguarda da função de reprodução" (Artigo 11). ${ }^{206}$

De volta à OIT, a Convenção 156, de 1981, sobre a igualdade de tratamento para homens e mulheres trabalhadores com encargos familiares, previu medidas capazes de permitir que trabalhadores e trabalhadoras tenham igual oportunidade de ingressar, manter-se e progredir em atividade econômica, por meio da promoção de serviços comunitários e de instalações de cuidado para crianças e de amparo à família, como creches e pré-escolas. Este convênio mostra a evolução dos debates de gênero em âmbito internacional, compreendendo que a igualdade só é possível se fornecidos instrumentos que aliviem o peso das responsabilidades familiares para essas trabalhadoras. ${ }^{207}$

Entretanto, a restrição ao trabalho noturno das mulheres apenas foi revista pelo Protocolo de 1990, relativo à Convenção sobre Trabalho Noturno das Mulheres, que abriu a possibilidade das legislações nacionais introduzirem exceções à proibição do trabalho noturno feminino, desde que consultadas organizações representativas de empregadores e trabalhadores. Veda, porém, que tais exceções sejam aplicadas às trabalhadoras no período anterior e posterior ao parto, no mínimo por 16 semanas, salvo nos casos em que a trabalhadora solicite expressamente e na condição de que não exista perigo para sua saúde e de seu filho.

No mesmo ano, a OIT aprovou a Convenção 171 sobre Trabalho Noturno, que estabeleceu medidas específicas para trabalhadoras e trabalhadores

\footnotetext{
${ }^{205}$ Aprovada na ONU em 1979, pela Resolução n. 34/180; Ratificada pelo Brasil em 1984 (promulgada pelo Decreto $n^{\circ}$. 4.377, de 13 de setembro de 2002).

${ }^{206}$ ORGANIZAÇÃO DAS NAÇÕES UNIDAS. Convenção sobre a Eliminação de Todas as Formas de Violência contra a Mulher. New York: ONU, 1979. Disponível em: <http://www.planalto.gov.br/ccivil_03/decreto/2002/D4377.htm>. Acesso em: 30.jun.2014.

${ }^{207}$ Adotada pela OIT em 1981; não ratificada pelo Brasil.
} 
noturnos, a fim de proteger sua saúde, ajudar a cumprir suas responsabilidades familiares e sociais e compensá-los de forma adequada. A única proteção especial do convênio diz respeito às trabalhadoras gestantes, determinando a adoção de medidas para assegurar que exista alternativa ao trabalho noturno, bem como garantir a licençamaternidade $\left(\operatorname{artigo} 7^{\circ}\right){ }^{208}$

Desse modo, observamos que, gradualmente, a OIT passou a se orientar a partir da noção de proteção total ao trabalhador, independente do sexo. Assim, mantiveram-se apenas algumas restrições ao trabalho das mulheres, predominantemente aquelas destinadas à proteção da maternidade, que não configurassem medida discriminatória. ${ }^{209}$ Nos anos seguintes, a OIT determinou sua lista de princípios fundamentais, passando a pautar sua ação com base neles e na ideia de Trabalho Decente, conforme analisaremos em item posterior.

Além dos documentos internacionais com referência ao trabalho das mulheres, merece destaque ainda a Declaração de Direitos Humanos de Viena, de 1993, a primeira a explicitar que os direitos humanos das mulheres e das meninas são parte inalienável, integral e indivisível dos direitos humanos universais (parágrafo 18). Segundo Flávia Piovesan, Viena não apenas endossou a universalidade e a indivisibilidade dos direitos humanos, mas conferiu "visibilidade aos direitos humanos das mulheres e das meninas, em expressa alusão ao processo de especificação do sujeito de direito e à justiça enquanto reconhecimento de identidades". 210

Por fim, também é preciso mencionar a IV Conferência Mundial sobre as Mulheres, realizada em Pequim, no ano de 1995, que reiterou as concepções de Viena de que os direitos das mulheres são direitos humanos. ${ }^{211}$ Nesta conferência, os EstadosMembros comprometeram-se a adotar medidas para garantir "a inserção da perspectiva de gênero nas legislações e em políticas, programas e projetos estatais", acordo de

\footnotetext{
${ }^{208}$ Adotada pela OIT em 1990; ratificada pelo Brasil em 18.12.2002.

209 TUDOR, Talitha do Carmo. Trabalho da mulher - estágio atual. Revista Brasileira de Saúde Ocupacional, Ministério do Trabalho / Fundacentro, v. 38, n. 10, abr/mai/jun.1982. p. 43-47.

${ }^{210}$ PIOVESAN, Flávia. Direitos humanos das mulheres no Brasil: desafios e perspectivas. In: PENIDO, Laís de Oliveira (coord.). Igualdade dos gêneros nas relações de trabalho. Brasília: ESMPU, 2006. p. 205-212. p. 205.

211 Em 2015, a ONU irá avaliar a evolução da aplicação da Plataforma de Pequim, por meio de relatórios nacionais preparados pelos Estados-Membros, o que será feito em conjunto com campanhas de promoção dos direitos das mulheres em todo mundo. Este ciclo de reflexões e avaliação foi denominado Pequim+20 (Beijing Plus 20).
} 
fundamental importância para os estudos que buscam a integração entre o Direito e a perspectiva de gênero, tal como o presente trabalho. ${ }^{212}$

\subsubsection{Direito nacional}

No Brasil, a evolução legislativa deu-se de modo similar, muito devido às influências internacionais. A exceção, que diz muito sobre a história de nosso país, foi justamente a primeira tentativa de proteção da maternidade, ocorrida na Constituinte de 1823, quando José Bonifácio apresentou projeto que prescrevia que o trabalho das escravas fosse amenizado nos períodos próximos ao parto, com a seguinte prescrição: “A escrava, durante a prenhez e passado o terceiro mês, só será ocupada em casa, depois do parto terá um mês de convalescência, passado este, durante o ano, não trabalhará longe da cria". ${ }^{213}$

A Constituição do Império, de 1824, continha previsão embrionária de proteção ao meio ambiente do trabalho, no inciso XXIV do artigo 179: "Nenhum genero de trabalho, de cultura, indústria, ou commercio póde ser prohibido, uma vez que não se opponha aos costumes publicos, á segurança, e saude dos Cidadãos”. Diferente, a Constituição de 1891, não fez menção à saúde do cidadão, tampouco a qualquer proteção ao trabalho.

O Decreto $\mathrm{n}^{\circ}$. 16.300, de 31 de dezembro de 1923, regulamento do Departamento Nacional de Saúde Pública, foi a primeira norma federal a tratar expressamente do trabalho das mulheres. Entre os artigos 345 e 349, concede às trabalhadoras o direito ao repouso de 30 dias antes e 30 dias depois do parto e prevê a existência de creches ou salas de amamentação próximas à sede das empresas, para que as mães possam amamentar seus filhos em intervalos regulares.

Em 17 de maio de 1932, o Decreto $\mathrm{n}^{\circ}$. 21.417-A destinou-se a regular especificamente as condições do trabalho das mulheres nos estabelecimentos industriais e comerciais, servindo de base para o que posteriormente seriam os artigos da CLT sobre trabalho feminino. Assegurou a proteção à maternidade, com a previsão da licença da gestante por quatro semanas antes e quatro semanas depois do parto (artigo $7^{\circ}$ ), com

\footnotetext{
${ }^{212}$ PRÁ, Jussara Reis; EPPING, Léa. Cidadania e feminismo no reconhecimento dos direitos humanos das mulheres. Estudos Feministas, Florianópolis, v. 20, n.1, p. 33-51, jan./abr.2012. p. 41.

${ }^{213}$ VERONESE, Josiane Rose Petry. Os direitos da mulher na nova Constituição. Sequência - Estudos Jurídicos e Políticos, v. 11, n. 21, Florianópolis, p. 94-103, 1990. p. 95.
} 
direito a auxílio correspondente a metade de seu salário (artigo $9^{\circ}$ ), proibição da dispensa da mulher grávida sem justo motivo (artigo 13), direito da mãe a dois descansos diários para amamentação nos primeiros seis meses da criança, e obrigatoriedade de creches para empresas com mais de 30 mulheres (artigo 12).

Além disso, o Decreto $\mathrm{n}^{\circ}$. 21.417-A, de 1932, proibiu o trabalho das mulheres em serviços perigosos e insalubres, nos subterrâneos, minerações, pedreiras e obras de construção $\left(\operatorname{artigo} 5^{\circ}\right.$ ), bem como o levantamento de materiais pesados (artigo $4^{\circ}$ ) e o trabalho noturno (artigo $2^{\circ}$ ). Este, porém, mereceu exceções: trabalhadoras em estabelecimentos familiares; mulheres cujo trabalho fosse indispensável para evitar interrupção do funcionamento do estabelecimento; mulheres encarregadas do cuidado de enfermos em hospitais e sanatórios; mulheres empregadas em serviços de telefonia; e mulheres ocupantes de postos de direção (artigo $3^{\circ}$ ).

A Constituição de 1934 determinou, no Parágrafo $1^{\circ}$ do artigo 121, que a legislação do trabalho deve observar determinados preceitos para a melhoria das condições do trabalhador. Em relação às mulheres trabalhadoras, determinou a igualdade salarial entre os sexos (alínea 'a'), previu a "assistência médica e sanitária ao trabalhador e à gestante", assegurado o "descanso antes e depois do parto, sem prejuízo do salário e do emprego" (alínea ' $h$ '), e, seguindo as diretrizes do Decreto de 1932, proibiu o trabalho de mulheres e menores de 18 anos em indústrias insalubres (alínea 'd').

Em 1935, o Brasil ratificou a Convenção 3 da OIT, o que revogou os dispositivos a ela conflitantes do Decreto $\mathrm{n}^{\circ}$. 21.417-A e ampliou a duração da licençamaternidade de quatro para seis semanas antes e depois do parto.

A Constituição de 1937 representou retrocesso ao Direito do Trabalho das mulheres. Apesar de estarem presentes o preceito formal de igualdade (artigo 122) e a garantia à assistência médica e à licença da gestante (artigo 137, alínea '1'), foram eliminadas da Carta a proibição da diferença salarial entre os sexos e a garantia de emprego à gestante. Ademais, a proibição do trabalho em indústrias insalubres de mulheres e menores foi mantida (artigo 137, alínea ' $k$ '). Soma-se ao quadro reacionário a edição do Decreto-lei $n^{\circ}$. 2.548 de 1940, que estabeleceu a possibilidade de as mulheres perceberem salários inferiores aos dos homens, autorizando redução de até $10 \% .^{214}$

\footnotetext{
${ }^{214}$ BRASIL. Decreto-lei $n^{o}$. 2.548, de 31 de agosto de 1940. Art. $2^{\text {o }}$. "Para os trabalhadores adultos do sexo feminino, o salário mínimo, respeitada a igualdade com o que vigorar no local, para o trabalhador
} 
A CLT entrou em vigor em 1943, com uma série de dispositivos com referência direta às trabalhadoras, merecendo destaque o Capitulo II do Título II, intitulado "Da proteção do trabalho da mulher". Em termos de conteúdo, porém, não houve inovação, tendo sido compiladas normas já existentes sobre o tema e organizadas em cinco seções: duração e condições do trabalho, trabalho noturno, período de descanso, métodos e locais de trabalho e proteção à maternidade.

Para os fins aqui pretendidos, é inicialmente relevante o artigo 372, que previu a "proteção especial da mulher" no referido capítulo, com a ressalva do Parágrafo Único, que exclui a incidência de tais regras sobre o trabalho das mulheres em oficinas onde sirvam apenas pessoas de sua família e que estejam sob a direção do marido, do pai, da mãe, do tutor ou do filho.

Como primeiro desdobramento de tal "proteção especial", referente à duração do trabalho, o artigo 375 impunha que "nenhuma mulher poderá ter o seu horário de trabalho prorrogado, sem que esteja para isso autorizada por atestado médico oficial, constante de sua carteira profissional", excepcionando-se os casos de força maior (artigo 376). Foi determinada ainda, em caso de prorrogação do horário, a obrigatoriedade de um descanso de 15 minutos para a mulher antes do período extraordinário (artigo 384).

A seção seguinte determinou a proibição do trabalho noturno das mulheres, assim considerado aquele executado entre as 22 horas e as 5 horas do dia seguinte, mas previu a exclusão das seguintes atividades: empresas de telefonia, radiotelefonia ou radiotelegrafia; enfermagem; casas de diversões, hotéis, restaurantes, bares e estabelecimentos congêneres; postos de direção em trabalhos não contínuos (artigo 379).

O artigo 387 da CLT previu a proibição do trabalho das mulheres em subterrâneos, minerações em subsolo, pedreiras e obras de construção públicas e privadas, bem como nas atividades perigosas e insalubres. Também foi vedado o trabalho das mulheres em serviços que exigissem emprego de força muscular superior a 20 quilos para trabalho contínuo, ou 25 quilos para trabalho ocasional (artigo 390).

Quanto à proteção celetista às trabalhadoras gestantes e mães, foram mantidas as garantias do Decreto $n^{\circ}$. 21.417-A, com algumas ampliações: proibição da dispensa discriminatória da gestante (artigo 391); licença-maternidade de seis semanas

adulto do sexo masculino, poderá ser reduzido em 10\% (dez por cento), quando forem, no estabelecimento, observadas as condições de higiene estatuídas por lei para o trabalho de mulheres". 
antes e seis semanas após o parto (artigo 392); auxílio-maternidade referente ao salário integral da empregada (artigo 393); dois descansos de meia hora durante a jornada, para amamentação nos primeiros seis meses de idade do filho (artigo 396); dever da empresa com mais de 30 empregadas a fornecer creches para guarda dos filhos das empregadas no período de amamentação (artigo 389, Parágrafo único).

O artigo 389 consolidado previu a obrigação do empregador de prover estabelecimentos higiênicos, ventilados e iluminados, instalar bebedouros, lavatórios, banheiros, vestiários e dispor de assentos, para evitar o esgotamento físico das mulheres, e fornecer gratuitamente recursos de proteção individual, visando à segurança e conforto das trabalhadoras. Cabe aqui a crítica de que o direito à saúde e segurança no local de trabalho diz respeito à proteção do ser humano, não justificando a garantia legal restrita ao sexo feminino, que não se estenda a todos os trabalhadores e trabalhadoras, o que influenciou sua posterior reforma e universalização.

Por fim, a CLT ainda possuía dispositivo que facultava ao marido ou ao pai a rescisão do contrato de trabalho das mulheres "quando a sua continuação for suscetível de acarretar ameaça aos vínculos da família, perigo manifesto às condições peculiares da mulher" (artigo 446). Apesar de urgir a pergunta sobre quais seriam as tais “condições peculiares da mulher", claramente observamos neste dispositivo o argumento biológico das diferenças do organismo feminino, utilizado para reforçar o papel primário das mulheres na esfera reprodutiva e sua subjugação à família.

Vale destacar que esta disposição segue a linha legislativa da época, encabeçada pelo Código Civil de 1916, que tratava as mulheres como relativamente incapazes, equiparadas aos menores entre 16 e 21 anos, o que apenas foi superado com a entrada em vigor da Lei 4.121, de 27 de agosto de 1962, o chamado Estatuto da Mulher Casada. Entretanto, o artigo 446 e outros artigos consolidados de teor proibitivo sobre trabalho das mulheres apenas foram revogados após 1988, conforme será descrito adiante, no item dedicado à CLT.

A Constituição de 1946, em seu artigo 157, manteve os direitos e proibições relativos às mulheres trabalhadoras, a isonomia salarial (inciso II), ampliou a previsão de assistência sanitária ao trabalhador e à gestante, incluindo a assistência hospitalar e médica preventiva (inciso XIV), e tornou expresso constitucionalmente o preceito de higiene e segurança no trabalho (inciso VIII).

Os moldes da antecessora foram seguidos pela Constituição de 1967, com a inclusão da proibição da diferença de critérios de admissão por motivo de sexo, 
cor e estado civil (artigo 165, inciso III) e a garantia da aposentadoria para as mulheres aos trinta anos de trabalho (inciso XIX). Apesar das normas constitucionais e celetistas sobre medicina e segurança laboral em vigor, a situação acidentária no país avançou a ponto insustentável no período.

Nos anos 1970, o Brasil foi considerado o país com maior número de acidentes e doenças profissionais. A média de acidentes da década era de 1,5 milhão de acidentes de trabalho e 4 mil óbitos por ano, chegando a 1,9 milhão de acidentes em 1975, o que representava 14,74\% dos trabalhadores segurados da Previdência Social na época. $^{215}$

A situação calamitosa e as perdas para a economia do país constrangeram o governo militar a criar a Fundacentro, em 1965, instituição governamental voltada ao estudo e à pesquisa das condições ambientais de trabalho, posteriormente incorporada ao Ministério do Trabalho (1974). Nesse contexto, foi editada a Lei $\mathrm{n}^{\circ}$. 6.514, de 22 de dezembro de 1977, que atualizou o Capítulo V do Título II da CLT, referente à segurança e medicina do trabalho.

A nova redação do artigo 200 da CLT $^{216}$ do mencionado capítulo delegou ao Ministério do Trabalho a regulamentação das normas técnicas sobre o tema, de modo que em resposta a este dispositivo a Fundacentro elaborou as NR, aprovadas pela Portaria $n^{\circ} .3214$ do Ministério do Trabalho, de 8 de junho de 1978, e vigentes ainda hoje, com algumas alterações e inclusões.

Caminhou-se até a promulgação da CF, de 1988, que, baseada no princípio da igualdade material, mudou o rumo da legislação trabalhista no tocante às mulheres e alterou o paradigma da proibição para a proteção e promoção do trabalho feminino. Pela própria estrutura jurídica brasileira, a incorporação desse conflito ao texto constitucional alterou significativamente todo o restante do ordenamento referente ao tema. ${ }^{217}$

\footnotetext{
${ }^{215}$ TODESCHINI, Remígio; LINO, Domingos; MELO, Luiz Eduardo Alcântara de. O Ministério da Previdência Social e a institucionalidade no campo da saúde do trabalhador. In: CHAGAS, Ana Maria de Resende Chagas; SALIM, Celso Amorim; SERVO, Luciana Mendes Santos (org.). Saúde e segurança no trabalho no Brasil: aspectos institucionais, sistemas de informação e indicadores. Brasília: Ipea, 2011. p. 77-88.

${ }^{216}$ BRASIL. CLT. Art. 200. Cabe ao Ministério do Trabalho estabelecer disposições complementares às normas de que trata este Capítulo, tendo em vista as peculiaridades de cada atividade ou setor de trabalho (...).

${ }^{217}$ Sobre isso, ver BERCOVICI, Gilberto; MASSONETTO, Luis Fernando. Breve História da Incorporação dos Direitos Sociais nas Constituições Democráticas Brasileiras. Revista do Departamento de Direito do Trabalho e da Seguridade Social, v. 3, p. 61-84, 2007.
} 
Diante do panorama traçado, podemos observar a evolução das normas internacionais e nacionais referentes à saúde e segurança das mulheres no trabalho. Esta reconstrução histórica nos permitirá analisar com maior densidade crítica as normas em vigor referentes ao tema sob a égide dos novos paradigmas de igualdade, e também o modo como os fatores sexo e gênero foram inseridos nos textos normativos até o presente momento.

\subsection{Atualidade da normativa}

\subsubsection{Organização Internacional do Trabalho}

A Declaração dos Princípios e Direitos Fundamentais no Trabalho, de 1988, é a atual base da OIT, que vinculou a atuação da organização e dos EstadosMembros ao compromisso de respeito, promoção e efetivação dos seguintes princípios: liberdade de associação e liberdade sindical; eliminação de todas as formas de trabalho forçado; abolição do trabalho infantil; e eliminação da discriminação em matéria de emprego e ocupação. ${ }^{218}$

Adicionalmente, a OIT adotou o programa de promoção do Trabalho Decente em 1999, que sintetizou a missão da organização de promover oportunidades para que homens e mulheres possam exercer ocupação produtiva adequadamente remunerada e exercida em condições de liberdade, equidade e segurança, que garanta uma vida digna. ${ }^{219}$ Transversal aos quatro objetivos estratégicos do programa - criação de emprego de qualidade, garantia e respeito aos direitos dos trabalhadores, extensão da proteção social e fortalecimento do diálogo social -, ganha destaque a igualdade de gênero no trabalho. ${ }^{220}$

Circunscritas por tais princípios e direitos fundamentais e pela noção de trabalho decente, temos atualmente 82 Convenções da OIT ratificadas e vigentes no

\footnotetext{
218 Disponível em <http://www.ilo.org/declaration/thedeclaration/textdeclaration/lang--es/index.htm>. Acesso em: 10.jun.2013.

219 Disponível em <http://www.oitbrasil.org.br/content/apresenta\%C3\%A7\%C3\%A3o>. Acesso em: 10.jun.2013.

220 Disponível em <http://www.ilo.org/global/about-the-ilo/decent-work-agenda/lang--es/index.htm>. Acesso em: 10.jun.2013.
} 
Brasil, ${ }^{221}$ dentre as quais destacaremos aquelas que possuem ligação com o presente estudo.

Referentes à igualdade de gênero no trabalho, quatro Convenções foram designadas pela OIT como instrumentos-chave para seu alcance: Convenção 100, de 1951, sobre igualdade de remuneração; Convenção 111, de 1958, sobre Discriminação no emprego; Convenção 156, de 1981, sobre trabalhadores e trabalhadoras com responsabilidades familiares; e Convenção 183, de 2000, sobre proteção da maternidade. ${ }^{222}$ Destas, infelizmente, temos ratificadas apenas as duas primeiras.

Vale frisar que no tocante à proteção à maternidade, a Convenção 183 , revisou a Convenção 103 - esta sim ratificada pelo país e ainda em vigor -, ampliando o período mínimo de licença-maternidade para 14 semanas, com remuneração não inferior a dois terços da remuneração habitual, e reforçando as garantias de emprego da gestante e da lactante, como o direito à reintegração em caso de dispensa abusiva. ${ }^{223}$

\section{Complementar à Convenção 183, a Recomendação 191 possui} disposições sobre a proteção à saúde da gestante e lactante, prevendo seu afastamento de trabalhos que apresentem riscos às trabalhadoras, especialmente: penosos; de carga de peso; de contato com agentes biológicos, químicos ou físicos que possam prejudicar as funções reprodutivas; que exijam equilíbrio; que requeiram posições estáticas; que as exponham a temperaturas extremas ou a vibrações. Ainda dispõe que a mulher grávida ou lactante não deveria ser obrigada a realizar trabalho noturno quando certificado médico demonstrar que isso pode ser danoso a seu estado.

Referentes à saúde e segurança no trabalho, a Recomendação 197 da OIT relacionou as 16 Convenções pertinentes ao marco promocional do tema, dentre as quais 13 foram ratificadas pelo Brasil: Convenção 81, sobre inspeção do trabalho ${ }^{224}$; Convenção 115 , sobre radiações ${ }^{225}$; Convenção 120 , sobre higiene no comércio e

\footnotetext{
${ }^{221}$ Os tratados internacionais firmados pelo Brasil só se aplicam internamente quando ratificados, o que ocorre por decreto governamental, após aprovação do texto pelo Congresso Nacional, sendo incorporados ao nosso ordenamento jurídico com status de norma infraconstitucional. Especificamente os tratados sobre direitos humanos poderão ser equivalentes à Emenda Constitucional se aprovados nas casas do Congresso Nacional, em dois turnos, por três quintos dos votos dos respectivos membros (art. $5^{\circ}, \S 2^{\circ}$ da $\mathrm{CF})$.

222 ORGANIZAÇÃO INTERNACIONAL DO TRABALHO. $O$ ABC dos direitos das mulheres trabalhadoras e da igualdade de género. 2 ed. Genebra: OIT, 2007. p. 7.

${ }^{223}$ Adotada pela OIT em 2000; não ratificada pelo Brasil.

${ }^{224}$ Adotada pela OIT em 1947; ratificada pelo Brasil em 11.10.1989.

${ }^{225}$ Adotada pela OIT em 1960; ratificada pelo Brasil em 05.09.1966.
} 
escritórios $^{226}$; Convenção 139, sobre câncer profissional ${ }^{227}$; Convenção 148, sobre contaminação do ar, ruído e vibrações ${ }^{228}$; Convenção 152 , sobre segurança no trabalho portuário $^{229}$; Convenção 155 , sobre segurança e saúde dos trabalhadores ${ }^{230}$; Convenção 161, sobre serviços de saúde no trabalho ${ }^{231}$; Convenção 162 , sobre amianto $^{232}$; Convenção 167 , sobre segurança e saúde na construção ${ }^{233}$; Convenção 170 , sobre produtos químicos ${ }^{234}$; Convenção 174 , sobre prevenção de acidentes industriais ${ }^{235}$; e Convenção 176, sobre segurança e saúde nas minas ${ }^{236}$.

Além dos convênios supracitados, que tratam do trabalhador de maneira genérica, há outros que contêm dispositivos com ressalvas acerca da saúde e segurança das mulheres em específico. A Convenção 127, que dispõe sobre o peso máximo das cargas, prevê em seu artigo VII, que a designação de mulheres e jovens para o transporte de cargas deve ser limitado e que o peso máximo deve ser nitidamente inferior àquele admitido para homens. ${ }^{237}$ Também a Convenção 136, sobre os riscos da intoxicação por benzeno, determina no artigo 11 que as mulheres grávidas e lactantes não devem ser empregadas em trabalhos com exposição ao material. ${ }^{238}$

Há outras importantes Convenções sobre o tema que não foram ratificadas pelo Brasil. Dentre elas, a Convenção 184, de 2001, sobre segurança e saúde na agricultura, cujo artigo 18 estabelece o dever de adoção de medidas que levem em conta as necessidades próprias das trabalhadoras rurais, em particular aquelas relacionadas com a gravidez, aleitamento e saúde reprodutiva. Também a Convenção 187, de 2006, sobre promoção da segurança e saúde no trabalho, que foi estruturada no sentido de fomentar a existência de uma cultura preventiva, que não aceita trabalho sem

\footnotetext{
${ }^{226}$ Adotada pela OIT em 1964; ratificada pelo Brasil em 24.03.1969.

${ }^{227}$ Adotada pela OIT em 1974; ratificada pelo Brasil em 27.06.1990.

${ }^{228}$ Adotada pela OIT em 1977; ratificada pelo Brasil em 14.01.1982.

${ }^{229}$ Adotada pela OIT em 1979; ratificada pelo Brasil em 18.05.1990.

${ }^{230}$ Adotada pela OIT em 1981; ratificada pelo Brasil em 18.05.1992.

${ }^{231}$ Adotada pela OIT em 1985; ratificada pelo Brasil em 18.05.1990.

${ }^{232}$ Adotada pela OIT em 1986; ratificada pelo Brasil em 18.05.1990.

${ }^{233}$ Adotada pela OIT em 1988; ratificada pelo Brasil em 19.05.2006.

${ }^{234}$ Adotada pela OIT em 1990; ratificada pelo Brasil em 23.12.1996.

${ }^{235}$ Adotada pela OIT em 1993; ratificada pelo Brasil em 02.08.2001.

${ }^{236}$ Adotada pela OIT em 1995; ratificada pelo Brasil em 18.05.2006.

${ }^{237}$ Adotada pela OIT em 1967; ratificada pelo Brasil em 21.08.1970.

${ }^{238}$ Adotada pela OIT em 1971; ratificada pelo Brasil em 24.03.1993.
} 
segurança. Vale dizer, ainda, que a Convenção 189, de 2011 sobre trabalho doméstico, prevê às trabalhadoras e trabalhadores o direito a um ambiente laboral saudável e seguro (artigo 13).

Por fim, destacamos que a campanha do programa Trabalho Decente entre os anos de 2008 e 2009 foi "A igualdade de gênero no coração do trabalho decente", que, entre seus temas, abordou a questão da saúde e segurança no trabalho de homens e mulheres. ${ }^{239}$ Resultado dela, a Resolução sobre Igualdade de Gênero no Coração do Trabalho Decente, de 2009, destaca em seus dispositivos a "importância da realização de um número maior de pesquisas acerca do impacto diferenciado, sobre homens e mulheres, dos riscos ocupacionais presentes no local de trabalho" (§ 26) e determina que a OIT deve "promover políticas, culturas e sistemas de segurança e saúde no trabalho sensíveis às questões de gênero" (§ 54).

\subsubsection{Ordenamento jurídico nacional}

\subsubsection{A Constituição de 1988}

A $\mathrm{CF}$, fruto da efervescente luta pela liberdade pós ditatura militar, trouxe novos princípios ao ordenamento jurídico brasileiro, como a proibição de toda forma de discriminação inclusive em relação ao sexo (artigo $3^{\circ}$, inciso IV e artigo $5^{\circ}$, caput e inciso I) e a declaração da igualdade entre homem e mulher na sociedade conjugal (artigo 226, $\S 5^{\circ}$ ), dando início a um processo de adaptação do restante do sistema normativo a tais preceitos.

A Carta é considerada marco dos direitos sociais no Brasil, cuja tutela foi consagrada em seu artigo $6^{\circ}$, dentre os quais relaciona a saúde, trabalho, segurança, previdência social e a proteção à maternidade. Na mesma linha, ampliou e consolidou direitos trabalhistas, dando ênfase à proteção do trabalho. Em seu artigo $7^{\circ}$, fruto da atuação da classe operária em conjunto com o movimento de mulheres e outros movimentos sociais na Assembleia Constituinte, ${ }^{240}$ elenca direitos de trabalhadores e

\footnotetext{
${ }^{239}$ Disponível em <http://www.ilo.org/gender/Events/Campaign2008-2009/lang--es/index.htm>. Acesso em: 10.jun.2013.

${ }^{240}$ Sobre a atuação do movimento de mulheres na conquista de direitos na Assembleia Constituinte, ver: ANGOTTI, Bruna. A Constituição Federal de 1988 e a conquista formal dos direitos das mulheres. Cadernos da Escola do Parlamento: VI - Igualdade de Gênero I. São Paulo: Câmara Municipal, 2014. p. $12-20$.
} 
trabalhadoras urbanos, rurais e domésticos, que para fins do presente estudo merece especial atenção.

No tocante à saúde e segurança no trabalho, o artigo $7^{\circ}$ contém o inciso XXII, que prevê o direito à "redução dos riscos inerentes ao trabalho, por meio de normas de saúde, higiene e segurança", o inciso XXIII, sobre o "adicional de remuneração para as atividades penosas, insalubres ou perigosas" e o inciso XXVI, que prevê o "seguro contra acidentes de trabalho, a cargo do empregador".

O referido artigo possui ainda dispositivos que, apesar de não tratarem expressamente, resguardam a saúde e segurança no trabalho, que prescrevem: compensação do trabalho noturno por remuneração superior (inciso IX); limitação da jornada de trabalho a 8 horas diárias e 44 semanais (inciso XIII); jornada de seis horas para trabalho realizado em turnos ininterruptos de revezamento (inciso XIV); repouso semanal remunerado (inciso $\mathrm{XV}$ ); férias anuais remuneradas com adicional de pelo menos um terço (inciso XVII); e a proteção em face da automação (inciso XXVII).

Especificamente em relação às mulheres trabalhadoras, o artigo $7^{\circ}$ prevê a licença à gestante, sem prejuízo do emprego e do salário, com duração de 120 dias (inciso XVIII), a proteção do mercado de trabalho das mulheres mediante incentivos (inciso XX) e a proibição de diferença de salários, exercício de funções ou critério de admissão por motivo de sexo, cor ou estado civil (inciso XXX). Soma-se a estas garantias o artigo 10, inciso II, alínea ' $b$ ' do ADCT, que prevê a estabilidade temporária da empregada gestante, desde a confirmação da gravidez até cinco meses após o parto.

Especificamente em relação ao meio ambiente do trabalho, a CF estabelece, no artigo 126, que a saúde é direito de todas e todos e dever do Estado, "garantido mediante políticas sociais e econômicas que visem à redução do risco de doença e de outros agravos e ao acesso universal e igualitário às ações e serviços para sua promoção, proteção e recuperação". Ademais, seu artigo 200, inciso VIII determina que compete ao Sistema Único de Saúde “colaborar na proteção do meio ambiente, nele compreendido o do trabalho". Também define a competência da Justiça do Trabalho para processar e julgar as ações oriundas das relações de trabalho, no que se incluem aquelas que versam sobre saúde e segurança. 


\subsubsection{Consolidação das Leis do Trabalho}

Antes de tratar dos atuais artigos da CLT referentes à saúde e segurança das trabalhadoras, importante explicar que ela se aplica apenas às relações de emprego urbanas, estendida aos avulsos e avulsas, nos termos do artigo $7^{\circ}$, inciso XXIV, da CF, e aos empregados e empregadas rurais, por disposição expressa da Lei $n^{\circ}$. 5.889, de 1973. ${ }^{241}$ Desse modo, os dispositivos tratados a seguir aplicam-se às trabalhadoras com vínculo empregatício, seja formalizado ou comprovado em juízo, o que, mesmo assim, exclui uma grande parte da força de trabalho feminina da proteção labor-ambiental. ${ }^{242}$

O texto original da CLT referente ao trabalho das mulheres foi fundamentalmente alterado, processo que teve início com o já citado Estatuto da Mulher Casada, Lei nº 4.121 de 27 de agosto de 1962, que alterou o Código Civil da época no sentido de excluir a "mulher casada" da condição de relativamente incapaz, o que determinou a revogação do artigo consolidado e garantiu às mulheres o livre exercício de profissão remunerada, independente dos maridos.

No entanto, foi a CF que determinou a mudança de paradigma na CLT, deixando a ideia patriarcal de proteção às mulheres e migrando para a promoção da igualdade entre os sexos no trabalho. Isso se deu por meio da revogação de artigos limitadores e proibitivos do trabalho feminino, da inserção do combate à discriminação e da reformulação das normas de proteção às trabalhadoras mães. Nesse sentido, elucida Maurício Godinho Delgado que a CF, por meio do artigo $5^{\circ}$, caput e inciso I, e do artigo $7^{\circ}$, incisos $\mathrm{XX}$ e XXX, "eliminou do direito brasileiro qualquer prática discriminatória contra a mulher no contexto empregatício - ou que lhe pudesse restringir o mercado de trabalho - ainda que justificada a prática jurídica pelo fundamento da proteção". ${ }^{243}$

A partir de agora, buscaremos demonstrar tal mudança de paradigma na CLT, chegando às regras atualmente vigentes. Para isso, dividiremos nossa exposição crítica com base nas seções do Capítulo consolidado "Da Proteção do Trabalho da

\footnotetext{
${ }^{241}$ BRASIL. Lei $n^{o}$. 5.889, de 8 de julho de 1973. Art. $1^{\circ}$ As relações de trabalho rural serão reguladas por esta Lei e, no que com ela não colidirem, pelas normas da Consolidação das Leis do Trabalho, aprovada pelo Decreto-lei $\mathrm{n}^{\circ}$. 5.452, de 01.05.1943.

${ }^{242}$ Debate-se se a EC 72/2013 possibilitou a aplicação da CLT às empregadas e empregados domésticos, por conta da alteração do Parágrafo Único do art. $7^{\circ}$ da CF. Por enquanto, certo apenas que a Lei $\mathrm{n}^{\circ}$. 5.859 , de 1972, não foi revogada.

${ }^{243}$ DELGADO, Maurício Godinho. Proteções contra discriminação na relação de emprego. In: VIANA, Márcio Túlio; RENAULT, Luiz Otávio Linhares (coord.). Discriminação. São Paulo: LTr, 2000. p. 97108. p. 102 .
} 
Mulher": condições do trabalho; trabalho noturno; períodos de descanso; métodos e locais de trabalho; e proteção à maternidade.

A Seção I, denominada "Da duração e condições de trabalho", foi praticamente toda alterada, sendo que apenas os artigos 372 (preceitos do trabalho masculino aplicáveis ao trabalho feminino), 373 (duração normal de trabalho das mulheres de oito horas diárias) e 377 (medidas de proteção ao trabalho das mulheres não justificam a redução de salário) mantêm a redação original. ${ }^{244}$

Importante alteração na Seção I deu-se no pós-1988, quando a Lei nº. 7.855, de 24 de outubro de 1989, revogou os artigos 374, 375 e 378, que limitavam a possibilidade das mulheres trabalharem em jornada extraordinária e proibiam a prorrogação do trabalho caso não houvesse autorização em atestado médico oficial, feito em carteira de trabalho. Entretanto, o artigo 376, que proibia a realização de horas extraordinárias por mulheres, com exceção de "casos excepcionais, por motivo de força maior", apenas foi revogado pela Lei nº.10.244, de 27 de junho de 2001.

Além disso, por força da Lei nº 9.799, de 26 de maio de 1999, a Seção I passou a tratar também das medidas contra a discriminação das mulheres no trabalho. A referida Seção passou, assim, a se chamar "Da duração, condições do trabalho e da discriminação contra a mulher" e foi inserido o artigo 373-A consolidado. Para nosso estudo, é relevante seu inciso IV, que proíbe empregadores de exigir atestado ou exame de esterilidade ou gravidez, para admissão ou permanência no emprego.

Vale destacar que esta alteração na CLT baseia-se na Lei $n^{\circ} .9 .029$, de 13 de abril de 1995, que primeiro inaugurou a proibição da exigência de atestados de gravidez e esterilização e de outras das práticas discriminatórias para admissão ou permanência da relação de trabalho.

A Seção II, que trata "Do Trabalho Noturno", originalmente era composta pelo artigo 379, 380 e 381, dos quais resta em vigor apenas o último, com dispositivo equivalente ao artigo 73 da CLT, prevendo a remuneração do trabalho noturno com acréscimo mínimo de $20 \%$ e hora noturna equivalente a 52 minutos e 30 segundos, o que é valido para todos os trabalhadores e trabalhadoras.

\footnotetext{
${ }^{244}$ Vale aqui problematizar o porquê de o art. 372 permanecer em vigor, pois representa claramente a lógica sexista de necessidade de tutela das mulheres trabalhadoras. Dentro dessa lógica, o Estado não precisaria "zelar" pelo trabalho feminino quando este estivesse sob a tutela de membro da família hierarquicamente superior, hierarquia esta definida pelo sexo (o marido, o pai, o filho) ou pela geração (a mãe).
} 
Em compensação, os artigos 379 e 380, que tratavam da proibição do trabalho noturno feminino, foram revogados na onda de alterações provocadas pela $\mathrm{CF}$, por meio da já citada Lei no .7 .855 , de 1989. Contudo, é interessante notar que, muito antes da revogação, foi inserida no artigo 379 uma série de exceções à proibição, de modo a permitir que as mulheres exercessem atividades noturnas em determinados serviços.

A redação original do artigo 379 vedava às mulheres o trabalho noturno, excluindo da proibição as empregadas maiores de 18 anos no setor de telefonia ou em serviços de enfermagem, empregadas maiores de 21 anos empregadas em casas de diversões, hotéis, restaurantes, bares e similares, mulheres ocupantes de postos de direção quando não participando de trabalho contínuo. A normativa era complementada pelo artigo 380, que previa que para o trabalho feminino noturno em casas de diversões, hotéis, bares e restaurantes era obrigatória a apresentação de "atestado de bons antecedentes" e "atestado de capacidade física e mental".

A primeira alteração sofrida pelo artigo 379 decorreu do Decreto-Lei $n^{\circ}$. 229/1967, que igualou em 18 anos a idade mínima da mulher para que ela pudesse enquadrar-se em uma das exceções e, além das já previstas, permitiu o trabalho noturno das mulheres em mais um local: estabelecimentos de ensino.

O Decreto-Lei $n^{\circ} .774$, de 6 de agosto de 1969, alterou a redação original do artigo 379, ampliando o termo "serviços de enfermagem" para "serviço de saúde e bem-estar" e "postos de direção" para "cargos técnicos ou postos de direção, gerência, assessoramento ou confiança". Ainda acrescentou três novas exceções: trabalho na industrialização de produtos perecíveis a curto prazo durante o período de safra ou em casos em que a matéria-prima forem suscetíveis a alteração rápida; força maior; e estabelecimentos bancários.

No rol de exceções do artigo 379, também foram inseridos, pela Lei $\mathrm{n}^{\circ}$. 5.673, de 6 de julho 1971, os serviços de processamento de dados para execução de tarefas pertinentes à computação e o trabalho em indústrias de manufaturados de couro que mantenham contratos de exportação autorizados pelos órgãos públicos competentes. Chegamos, assim, a onze exceções à proibição ao emprego de mulheres no trabalho noturno.

Por fim, antes da revogação definitiva, a Lei nº 7.189 , de 1984, alterou a lógica do artigo 379, cujo caput passou a permitir o trabalho noturno das mulheres, "salvo em empresas ou atividades industriais", sendo que esta proibição não se aplicaria 
a mulheres em posto de direção ou qualificação técnica com acentuada responsabilidade, a empregadas em serviços de higiene e bem-estar e a empresas de industrialização de bens perecíveis no período de safra. No entanto, seu parágrafo $5^{\circ}$ previu que o trabalho noturno das mulheres, independente do local, apenas seria permitido quando "a aptidão para executá-lo" estivesse atestada em exame médico, nos termos do artigo 380 da CLT, que seguiu inalterado ao longo destes anos.

Na Seção III, "Dos Períodos de Descanso", não houve mudança entre a redação original e a vigente. Além de artigos que sobre intervalo intra e interjornada e descanso semanal remunerado - para o que não há diferença entre trabalhadores homens e mulheres -, há o artigo 384, que determina o descanso obrigatório de 15 minutos para as mulheres antes da realização de jornada extraordinária. Declarado constitucional pelo Tribunal Pleno do TST, ${ }^{245}$ o intervalo de 15 minutos tem sido concedido às trabalhadoras nos tribunais trabalhistas, sob o argumento de que as mulheres teriam maior desgaste físico e mental que os homens.

Esta interpretação foi a que prevaleceu também no STF, que - depois de anos de debate acerca da recepção ou não recepção pela CF do referido dispositivo, bem como da possibilidade de extensão dos 15 minutos, pelo princípio da igualdade, aos trabalhadores do sexo masculino - julgou Recurso Extraordinário $\mathrm{n}^{\mathrm{o}}$. 658.312/SC, declarando que o artigo 384 da CLT foi recepcionado pela CF e que a norma se aplica às mulheres. ${ }^{246}$ Entendemos que os argumentos utilizados para fundamentar tal decisão são predominantemente biologicistas, questão sobre a qual nos debruçaremos no capítulo 4.

A Seção IV, intitulada "Métodos e Locais de Trabalho", possuía o artigo 387, que proibia o trabalho das mulheres nos subterrâneos, minerações, nas pedreiras e obras de construção, e nas atividades perigosas ou insalubres, sob o mesmo argumento de proteção ao organismo feminino mais frágil. Tal artigo foi revogado pela Lei $\mathrm{n}^{\circ}$. 7.855, de 1989, que ainda inseriu no capítulo dispositivos de incentivo ao trabalho das mulheres e seu aperfeiçoamento profissional (artigos 390-B, 390-C e 390-E).

Continua em vigor o artigo 389, cuja única alteração ocorreu por força do Decreto-Lei $\mathrm{n}^{\circ}$. 229 de 1967, que estabelece a obrigação de as empresas proverem

\footnotetext{
${ }^{245}$ BRASIL. TST. Incidente de Inconstitucionalidade em Recurso de Revista n. 1.540.2005.046.12.00-5. Tribunal Pleno. Relator Ministro Ives Gandra Martins Filho. Publicação no DEJT em 13.02.2009.

${ }^{246}$ BRASIL. STF. Recurso Extraordinário $n^{o}$. 658.312/SC. Relator Ministro Dias Toffoli. Julgado em 27.nov.2014.
} 
medidas de saúde, segurança e higiene no local de trabalho, no que se inclui a instalação de sanitários e vestiários e o fornecimento de EPI gratuitamente.

Ademais, permanece vigente o artigo 390, que veda o trabalho das mulheres "em serviço que demande o emprego de força muscular superior a 20 quilos para trabalho contínuo, ou 25 quilos para o trabalho ocasional". Vale mencionar que o artigo 198 da CLT, aplicável aos trabalhadores "em geral”, delimita 60 quilogramas como peso máximo para movimentação de carga, "ressalvadas as disposições específicas relativas ao trabalho do menor e da mulher". 247

Por fim, a Seção V trata "Da Proteção à Maternidade" nos artigos 391 a 401. O artigo 391, vigente em sua redação original, determina que matrimônio e gravidez não constituem justo motivo para rescisão do contrato de trabalho. Complemento a esta disposição foi dado pelo ADCT de 1988, que em seu artigo 10, inciso II, alínea 'b', prevê a estabilidade temporária da gestante, desde a confirmação da gravidez até cinco meses após o parto.

Em relação à licença-maternidade, o artigo 392 inicialmente proibia o trabalho das mulheres no período de seis semanas antes e seis semanas depois do parto. O Decreto-lei $\mathrm{n}^{\circ} .229$, de 1967, alterou a divisão do período de licença para quatro semanas antes e oito semanas depois do parto. Em 1999, a Lei no 9.799 manteve as garantias anteriores e inseriu a previsão de transferência de função em casos de riscos à gravidez e o direito à dispensa para consultas médicas e exames complementares, sem prejuízo do salário. Por fim, a previsão expressa de 120 dias de licença-maternidade foi fruto da alteração da Lei $n^{\circ}$. 10.421, de 2002, nos mesmos termos constitucionais. ${ }^{248}$

Esta mesma lei de 2002 trouxe um importante avanço à nossa legislação trabalhista, que foi a extensão da licença-maternidade para a mãe adotante, por meio da inserção do artigo 392-A à CLT. Destaca-se que a Lei ${ }^{\circ}$. 12.010, de 3 de agosto de

\footnotetext{
${ }^{247}$ Em relação à diferenciação por sexo da carga de peso no trabalho, vale mencionar também a diferenciação por idade e sexo, feita pelo Decreto $\mathrm{n}^{\circ}$. 6.481, de 1998 , que trata da proibição das piores formas de trabalho infantil nos termos da Convenção 182 da OIT. Na lista de piores formas de trabalho infantil do Decreto, incluem-se como trabalhos prejudiciais à saúde e segurança de menores aqueles "com levantamento, transporte, carga ou descarga manual de pesos, quando realizados raramente, superiores a 20 quilos, para o gênero masculino e superiores a 15 quilos para o gênero feminino; e superiores a 11 quilos para o gênero masculino e superiores a 7 quilos para o gênero feminino, quando realizados frequentemente" (item 80).

${ }^{248}$ A Lei $n^{\circ}$. 11.770, de 2008 criou o Programa Empresa Cidadã, que permite à empresa aderente a prorrogação da licença maternidade para 180 dias em troca de benefício fiscal e desde que a empregada gestante o requeira. No entanto, esta prorrogação não é direito de todas as trabalhadoras, dependendo da iniciativa empresa e da gestante, sendo certo que somente podem se beneficiar da isenção fiscal as empresas tributadas pelo lucro real, deixando-se de fora, portanto, as empregadas das microempresas e das empresas de pequeno porte, além das empregadas de pessoas físicas, empregadas de entidades sem fins lucrativos e um sem número de outras empregadas que não pertençam a grandes corporações.
} 
2009, equiparou definitivamente a mãe biológica da adotante, revogando os incisos que diferenciavam os períodos de licença-maternidade com base na idade da criança adotada, unificando o direito aos 120 dias.

Neste mesmo dispositivo, alteração recente e de extrema relevância para a igualdade de direitos entre homens e mulheres foi trazida pela Lei ${ }^{\circ}$. 12.873, de 24 de outubro de 2013, que estendeu aos pais trabalhadores o direito ao salário-maternidade, tanto em caso de falecimento da mãe, quanto em caso de adoção em que ele seja a parte do casal que optou por cuidar da criança. Essas recentes inserções na CLT merecem ser aqui transcritas:

Artigo 392-A. §5 . A adoção ou guarda judicial conjunta ensejará a concessão de licença-maternidade a apenas um dos adotantes ou guardiães empregado ou empregada.

Artigo 392-B. Em caso de morte da genitora, é assegurado ao cônjuge ou companheiro empregado o gozo de licença por todo o período da licença-maternidade ou pelo tempo restante a que teria direito a mãe, exceto no caso de falecimento do filho ou de seu abandono.

Artigo 392-C. Aplica-se, no que couber, o disposto no artigo 392-A e 392-B ao empregado que adotar ou obtiver guarda judicial para fins de adoção.

O salário-maternidade em si, complementar à licença-maternidade, está previsto no artigo 393, que determina que este seja equivalente ao salário integral da trabalhadora. A mudança ocorrida aqui derivou da Lei $n^{\circ}$. 6.136, 7 de novembro de 1974, que alterou a previsão inicial da CLT de que esta prestação fosse ônus do empregador, transferindo tal encargo para a Previdência Social, passo importante, vale dizer, no combate à discriminação das mulheres trabalhadoras.

Com redação inalterada desde 1943, o artigo 394 confere às mulheres grávidas a faculdade de romper a relação de emprego que possa causar prejuízos à gestação. Também com a redação original, o artigo 395 prevê repouso remunerado de duas semanas em caso de aborto não criminoso, o que merece crítica, uma vez que se o repouso destina-se à proteger a saúde das mulheres, o modo como ocorreu a interrupção da gravidez não tem relação com o organismo feminino. ${ }^{249}$

\footnotetext{
${ }^{249}$ Cabe frisar que a Lei $\mathrm{n}^{\circ} .8 .921$, de 1994, alterou o artigo 131 da CLT, retirando a expressão "aborto criminoso", de modo que consta apenas "aborto" entre os motivos que justificam a ausência no trabalho para fins de abono da falta no serviço. Entretanto, entendemos que a alteração do artigo 131 não foi suficiente para afastar o preconceito contra as mulheres, uma vez que o artigo 395 continua vinculando o direito à licença de duas semanas ao aborto não criminoso. Além de ineficaz, ao passo que nenhuma mulher irá, de fato, confessar o crime perante o empregador para não ter a falta compensada, o dispositivo demonstra misoginia, uma vez que não se contenta com a punição na esfera penal, causando ainda mais sofrimento para esta mulher. O Brasil precisa urgentemente descriminalizar o aborto, ou continuaremos
} 
A parte final da Seção V trata do cuidado dos filhos de trabalhadoras após o nascimento. Assim, o artigo 396 concede às mulheres o direito a dois descansos especiais de meia hora cada para amamentação do filho até os seis meses de idade. Os artigos 397, 398 e 400 da CLT tratam do fornecimento de creches para guarda dos filhos de trabalhadoras, que deveriam ser mantidas tanto pelos empregadores quanto pelo Estado.

Além do capítulo específico sobre a proteção do trabalho das mulheres, a CLT possui também o Capítulo V do Título II, intitulado "Da Segurança e da Medicina do Trabalho", que atualmente abarca os artigos 154 a 201, no qual estão as regras mínimas sobre o tema, como inspeção, prevenção, uso de EPI e atividades insalubres e perigosas, mencionando a especificidade do trabalho feminino apenas no já citado artigo 198, sobre carga máxima de peso.

Importante neste capítulo, para nosso estudo, é a disposição do artigo 200 consolidado, que delega ao Ministério do Trabalho a regulamentação da saúde e segurança do trabalho, por conta das "peculiaridades de cada atividade ou setor de trabalho". Desse modo, incumbiu a órgão técnico especializado a disciplina da matéria, o que foi feito em 1978, por meio da Portaria $\mathrm{n}^{\circ} .3214$ do Ministério do Trabalho, dando origem às NR, que analisaremos a seguir.

\subsubsection{As Normas Regulamentadoras}

A Portaria do Ministério do Trabalho $\mathrm{n}^{\mathrm{o}}$. 3214, de 8 de junho de 1978, aprovou 28 NR, com o objetivo de regulamentar e dar parâmetros mínimos para a saúde e segurança de trabalhadores e trabalhadoras brasileiros, consolidando a normativa nacional sobre saúde ocupacional e possibilitando a mensuração técnicas dos riscos laborais.

Originalmente, as NR desenvolvidas pela equipe de especialistas da Fundacentro eram divididas por temas e tinham previsão de revisões permanentes, com o objetivo de adequar seus parâmetros à evolução do conhecimento técnico sobre riscos no trabalho e às mudanças no mundo do trabalho. No entanto, poucas atualizações

matando um grande número de mulheres. Apoiamo-nos na sabedoria do movimento de mulheres: "educação sexual para escolher; contracepção para prevenir; aborto para não morrer". 
aconteceram e a edição de oito novas NR específicas para determinados setores profissionais desvirtuou da sua divisão temática. ${ }^{250}$

A maioria das NR trata os trabalhadores e trabalhadoras de modo genérico, traçando normas gerais de saúde e segurança ocupacional. Apenas as NR 15, 17, 30, 31 e 32 possuem dispositivos especificamente destinados às mulheres trabalhadoras. No caso da NR 30, há determinação da manutenção de alojamentos nos navios com dormitórios separados por sexo, o que, a nosso ver, é importante por garantir a intimidade e a segurança das trabalhadoras contra algum tipo de assédio por parte de seus colegas.

As regras específicas nas NR 31 e 32 visam à proteção da saúde das trabalhadoras mães e, principalmente, de seus filhos. Desse modo, a NR 31 veda a manipulação de "quaisquer agrotóxicos, adjuvantes e produtos afins" por gestantes e determina que o empregador rural afaste a gestante "das atividades com exposição direta ou indireta a agrotóxicos, imediatamente após ser informado da gestação". De modo similar, a NR 32 dispõe que as trabalhadoras gestantes somente serão liberadas para o trabalho em áreas com possibilidade de exposição a gases ou vapores anestésicos depois de autorizadas por médico responsável pelo PCMSO e impõe ao empregador o dever de afastar gestantes e nutrizes das atividades relacionadas a quimioterápicos antineoplásicos.

\footnotetext{
${ }^{250}$ Lista original da Portaria n. 3214, de 8 de junho de 1978: NR1, com disposições gerais sobre a aplicação das NR; NR2, que trata da inspeção prévia; NR3, sobre embargo de obra ou interdição de estabelecimento que oferecer risco aos trabalhadores; NR4, sobre a obrigatoriedade dos Serviços Especializados em Engenharia de Segurança em Medicina do Trabalho (SESMT); NR5, sobre as Comissões Internas de Prevenção de Acidentes (CIPA); NR6, com regras para uso do EPI; NR7, sobre a obrigatoriedade do Programa de Controle Médico de Saúde Ocupacional (PCMSO); NR8, sobre segurança em edificações; NR9, determinando a elaboração do Programa de Prevenção de Riscos Ambientais (PPRA); NR10, sobre segurança no trabalho com instalações e serviços de eletricidade; NR11, com regras de segurança para transporte, movimentação, armazenagem e manuseio de materiais; NR12, sobre segurança em máquinas e equipamentos; NR13, sobre caldeiras; NR14, que trata de fornos; NR15, que fixa limites para as atividades insalubres; NR16, sobre atividades perigosas; NR17, referente à ergonomia; NR18, sobre condições de trabalho na indústria da construção; NR19, com regras para depósito, manuseio e armazenagem de explosivos; NR20, sobre segurança no trabalho com líquidos combustíveis e inflamáveis; NR21, sobre trabalho a céu aberto; NR22, sobre saúde e segurança em trabalhos subterrâneos (mineração); NR23, com regras de proteção contra incêndios; NR24, sobre condições sanitárias dos locais de trabalho; NR25, sobre eliminação e tratamento de resíduos industriais; NR26, com regras de sinalização de segurança no trabalho; NR27, revogada pela Portaria do MTE n. 262, de 2008, tratava do registro profissional do técnico de segurança do trabalho; NR28, sobre a fiscalização do cumprimento das regras de saúde e segurança do trabalho e punições. Além destas, vigentes hoje estão também: NR29, com regras de saúde e segurança para o trabalho portuário; NR30, sobre o trabalho aquaviário; NR31, sobre trabalho rural; NR32, sobre saúde e segurança no trabalho em serviços de saúde; NR33, com regras de saúde e segurança para trabalho em espaços confinados; NR34, sobre as condições de trabalho na indústria naval; NR35, sobre trabalho em altura; e NR36, que trata da saúde e segurança no trabalho em empresas de abate e processamento de carnes e derivados.
} 
A NR 15 praticamente não diferencia homens e mulheres no tocante aos limites de tolerância para trabalhos insalubres e à ergonomia. Somente o Anexo 13-A, sobre benzeno, dispõe sobre a necessidade de a empresa especificar no Programa de Prevenção da Exposição Ocupacional ao Benzeno os procedimentos específicos de proteção para o trabalho de mulheres grávidas ou em período de amamentação. Ademais, seu Anexo 5, sobre radiações ionizantes, determina a utilização dos limites de tolerância constantes na Norma CNEN-NE-3.01, de 1988, intitulada Diretrizes Básicas de Radioproteção. Esta sim determina patamar de exposição diferenciado para as gestantes, nos termos do item 5.4.2.2, preocupando-se também em prescrever que "a notificação da gravidez não deve ser considerada um motivo para excluir uma mulher ocupacionalmente exposta do trabalho com radiação".

Em relação à NR 17, ela apenas estipula, genericamente, que "quando mulheres e trabalhadores jovens forem designados para o transporte manual de cargas, $o$ peso máximo destas cargas deverá ser nitidamente inferior àquele admitido para os homens".

Dessa forma, constatamos que as NR, de maneira geral, ditam regras de proteção à saúde dos trabalhadores e trabalhadoras sem diferenciação, com base em um "padrão geral", deixando de lado as diferenças entre os sexos, se de fato existirem, e pouco mencionando sobre a saúde e segurança das gestantes, das nutrizes e de seus filhos e filhas.

Apesar dessa relativa omissão das NR, é de suma importância atentarmos para a previsão da NR9, no item 9.3.5.1, de que em caso da ausência de limites de exposição ocupacional a agentes insalubres na NR15, poderão ser considerados os valores adotados pela ACGIH - American Conference of Governmental Industrial Higyenists. $^{251}$

De acordo com sua Declaração de Princípios, a ACGIH é instituição não governamental dos Estados Unidos, que na condição de associação que edita anualmente guias com o compilado dos dados publicados na literatura científica sobre índices seguros de exposição ocupacional a agentes químicos, físicos e biológicos,

\footnotetext{
${ }^{251}$ BRASIL. Portaria do Ministério do Trabalho n. 3214, de 08 de junho de 1978 - NR 9. 9.3.5.1. c) quando os resultados das avaliações quantitativas da exposição dos trabalhadores excederem os valores dos limites previstos na NR-15 ou, na ausência destes, os valores limites de exposição ocupacional adotados pela ACGIH - American Conference of Governmental Industrial Higyenists, ou aqueles que venham a ser estabelecidos em negociação coletiva de trabalho, desde que mais rigorosos do que os critérios técnico-legais estabelecidos.
} 
denominados TVLs (Threshold Limit Values) e BEIs (Biological Expousure Indices). Apesar destes guias não poderem ser considerados padrões normativos, servem de diretrizes para profissionais da área de higiene, saúde e segurança ocupacional. ${ }^{252}$

Os guias da ACGIH revelam grande defasagem das normas brasileiras em relação à saúde e segurança no trabalho, sendo que muitos dos limites tolerados no Brasil são sensivelmente discrepantes. ${ }^{253}$ No que nos interessa, vale notar que a ACGIH não possui normas que diferenciam, por exemplo, a carga máxima de peso que homens e mulheres podem suportar no trabalho, ao mesmo tempo em que os TVLs fazem importantes distinções em relação a gestantes, por exemplo, na exposição do feto ao ruído, o que analisaremos no capítulo 3, referente à maternidade.

\subsubsection{Normas da seguridade social}

Apesar de o foco desta dissertação ser o Direito do Trabalho, importante falar dos pontos mais relevantes da Seguridade Social no tocante à assistência e concessão de benefícios às trabalhadoras que eventualmente tiverem sua saúde maculada, uma vez que o reconhecimento do acidente ou da doença relacionada ao trabalho depende do Direito Previdenciário.

Parte integrante do sistema de Seguridade Social no Brasil, conforme artigo 194 da CF, a Previdência Social, por meio do INSS, é responsável por amparar os trabalhadores e trabalhadoras vítimas de doenças e acidentes profissionais, cumprindo função de seguradora. Nestes casos, a segurada ou o segurado incapacitado para o trabalho por mais de 15 dias tem o direito ao pagamento de benefício previdenciário específico, o auxílio-doença acidentário.

Previsto pela Lei no ${ }^{\circ} 8.213$, de 24 de julho de 1991, o auxílio-acidente é concedido tanto em casos de acidente do trabalho, doença profissional e doença do trabalho, conceitos definidos pela lei e equiparados para fins de concessão do benefício. Conforme o artigo 19, acidente do trabalho é aquele que ocorre pelo exercício do trabalho e provoca "lesão corporal ou perturbação funcional que cause a morte ou a perda ou redução, permanente ou temporária, da capacidade para o trabalho".

\footnotetext{
${ }^{252}$ ACGIH. 2011: TVLs \& BEIs. Tradução: Associação Brasileira de Higienistas Ocupacionais. São Paulo: ABHO, 2011. p. ix.

${ }^{253}$ Exemplo é a comparação das tabelas de limites de exposição a ruído da ACGIH e da NR 15, cuja razão da progressão é diferente: se tomarmos um ruído de $100 \mathrm{~dB}$, o limite máximo de exposição para a ACGIH é de 15 minutos, enquanto na NR 15 é de uma hora.
} 
Por força do artigo 21 da Lei, também se equiparam ao acidente do trabalho, dentre outros: aqueles acidentes em que o trabalho não seja causa única, mas tenha contribuído diretamente para o prejuízo sofrido; os acidentes fora do local e horário de trabalho, desde que sofridos no cumprimento de ordem do empregador, na prestação espontânea de serviços visando a evitar prejuízos ou proporcionar proveito à empresa; em viagem a serviço do empregador; ou no percurso entre a residência e o local de trabalho.

Em relação às moléstias ligadas ao trabalho, o artigo 20 as define da seguinte maneira: doença profissional é aquela "produzida ou desencadeada pelo exercício do trabalho peculiar a determinada atividade", enquanto a doença do trabalho é "adquirida ou desencadeada em função de condições especiais em que o trabalho é realizado e com ele se relacione diretamente", devendo ambas constar em "relação elaborada pelo Ministério do Trabalho e da Previdência Social".

Atualmente, tal relação de doenças encontra-se no Anexo II do Regulamento da Previdência Social (Decreto no. 3.048, de 6 de maio de 1999). No entanto, importante descartar a previsão do parágrafo $2^{\circ}$ do mesmo artigo, a qual determina que a Previdência Social deve, em casos excepcionais, reconhecer doença que, mesmo não incluída nessa listagem, seja constatada como resultado das condições de execução do trabalho e a ele diretamente relacionado.

$\mathrm{Na}$ busca por melhorias do sistema, foi criada nova metodologia de reconhecimento das doenças relacionadas ao trabalho, chamada NTEP, que, regulado pela Lei $\mathrm{n}^{\circ}$. 11.430, de 26 de dezembro de 2006, e pelo Decreto $\mathrm{n}^{\circ} .6 .042$, de 2007, estabelece que sempre quando constatada elevada incidência epidemiológica de determinada doença no Sistema Único de Benefícios da Previdência, esta será enquadrada como de natureza acidentária.

A possibilidade de enquadramento, regida atualmente pelo Decreto $\mathrm{n}^{\circ}$. 6.957, de 2009, baseia-se na lógica de que se o trabalhador pertencer a certa atividade da Classificação Nacional de Atividade Econômica (CNAE) com alta incidência de determinada doença da CID, seu acometimento será enquadrado como doença profissional.

Segundo Remígio Todeschini, Domingos Lino e Luiz Eduardo Alcantara de Melo, "o NTEP coloca às claras o adoecimento no interior do local de trabalho e desnuda principalmente os setores de serviço, que, até então, apresentavam baixo registro de doenças profissionais e do trabalho, como os setores bancário e de serviços”. 
Foi essa nova metodologia que possibilitou, nos últimos anos, o maior reconhecimento de doenças como as LER/DORT e transtornos psíquicos como derivadas da relação de trabalho. ${ }^{254}$

Também é dever da Previdência Social o pagamento do saláriomaternidade, garantido às seguradas (mães biológicas ou adotantes) durante 120 dias, conforme regulação da Lei nº .8 .213 , de 1991. A abrangência do salário-maternidade foi ampliada pela já mencionada Lei $\mathrm{n}^{\circ}$. 12.873, de 2013, que estendeu o direito à percepção do salário-maternidade aos assegurados adotantes e ao cônjuge ou companheiro sobrevivente no caso de falecimento da segurada. Para esse fim, foram inseridos na Lei $\mathrm{n}^{\circ}$. 8.213 os artigos 71-A, 71-B e 71-C.

Outro pilar da Seguridade Social é a Saúde, concretizada hoje pelo SUS. Criado pela CF, em 1988, o SUS toma como base a saúde como direito fundamental do ser humano, sendo responsabilidade do Estado o "acesso universal e equitativo à saúde, a inseparabilidade da promoção, proteção e recuperação da saúde e a formação de uma rede regionalizada hierarquizada para proporcionar serviços". 255

Em relação à saúde de trabalhadores e trabalhadoras, o artigo $6^{\circ}$ da Lei $\mathrm{n}^{\circ}$. 8.080, de 19 de setembro de 1990, prevê no campo de atuação do SUS a execução de ações de saúde do trabalhador e a "colaboração na proteção do meio ambiente, nele compreendido o do trabalho". O parágrafo $3^{\circ}$ do mesmo dispositivo descreve como ações de saúde do trabalhador aquelas que se destinam, por meio de vigilância epidemiológica e sanitária, à "proteção da saúde dos trabalhadores, assim como visa à recuperação e reabilitação da saúde dos trabalhadores submetidos aos riscos e agravos advindos das condições de trabalho".

Desse modo, é fundamental a atuação do SUS não apenas na assistência ao trabalhador vítima de acidente do trabalho, doença do trabalho ou doença profissional, mas também na colheita de dados, no trabalho de informação aos trabalhadores e entidades de classe, e no controle dos riscos constatados. Inclusive, nos termos do mesmo artigo $6^{\circ}, \S 3^{\circ}$, inciso VII, da CF é também atribuição do SUS a

\footnotetext{
${ }^{254}$ TODESCHINI, Remígio; LINO, Domingos; MELO, Luiz Eduardo Alcântara de. O Ministério da Previdência Social e a institucionalidade no campo da saúde do trabalhador. In: CHAGAS, Ana Maria de Resende Chagas; SALIM, Celso Amorim; SERVO, Luciana Mendes Santos (org.). Saúde e segurança no trabalho no Brasil: aspectos institucionais, sistemas de informação e indicadores. Brasília: Ipea, 2011. p. 77-88.

255 ORGANIZAÇAO PANAMERICANA DE SAÚDE. Saúde nas Américas: Edição de 2012. Washington: OPAS, 2012. p. 78-79.
} 
revisão periódica de lista oficial de doenças relacionadas ao trabalho, instituída pela Portaria ${ }^{\circ}$. 1339 do Ministério da Saúde, de 18 de novembro de 1999.

\subsection{O olhar biologicista e sexista do Direito sobre o trabalho das mulheres}

O panorama histórico traçado nos itens anteriores revela que as normas referentes à saúde e segurança no trabalho das mulheres, tanto brasileiras quanto internacionais, inicialmente se basearam em uma série de proibições, que restringiam o acesso das mulheres à parcela significativa do mercado de trabalho, sob o argumento de proteger o organismo feminino, supostamente mais frágil. No entanto, grande parte das proibições revelaram-se derivadas do desconhecimento científico e preconceito, gerando discriminação ao invés de proteção às trabalhadoras.

A tutela jurídica do trabalho das mulheres até meados do século $\mathrm{XX}$, segundo Amauri Mascaro Nascimento, abarcou quatro aspectos:

a) capacidade para contratar trabalho, submetida a algumas restrições; b) proteção à maternidade, com paralisações forçadas, descansos obrigatórios maiores e imposição de condições destinadas a atender a sua situação de mãe; c) defesa do salário, objetivando-se evitar discriminações em detrimento da mulher; d) proibições, quer quanto à duração diária e semanal do trabalho, quer quanto a determinados tipos de atividades prejudiciais ao organismo do ser humano e que, portanto, devem ser reservadas somente para os homens. ${ }^{256}$

Os fundamentos utilizados para justificar a necessidade de regulação especial do trabalho feminino eram, basicamente, fisiológicos e sociais. O primeiro partia da ideia de que o corpo das mulheres possui características diversas do corpo dos homens, por ser mais vulnerável e de menor resistência física, merecendo tratamento compatível com tal fragilidade. O outro se fundava no argumento da defesa da família, que tornava necessária a proteção das mulheres no seu papel doméstico, garantindo que as ocupações profissionais não interferissem em seu papel de mãe e nas responsabilidades domésticas.

Em análise sobre o tema, Alice Monteiro de Barros afirma que a tutela especial das mulheres no trabalho, sobretudo tratando-se das proibições, era sustentada pelo argumento da delicadeza e suscetibilidade femininas, aliadas à sua "natural"

\footnotetext{
${ }^{256}$ NASCIMENTO, Amauri Mascaro. Curso de Direito do Trabalho. $27^{\mathrm{a}}$ edição. São Paulo: Saraiva, 2012. p. 930.
} 
vocação para o lar. A autora ainda aponta como principais fundamentos dessa legislação protecionista:

(...) motivos fisiológicos e de eugenia, ligados, respectivamente, à função reprodutora e ao fortalecimento da raça, para justificar a licença-maternidade e os intervalos destinados ao aleitamento; motivos biológicos, provenientes da debilidade física, capazes de determinar a proibição de trabalhos perigosos, insalubres e as medidas especiais de higiene e segurança; finalmente, razões espirituais, morais e familiares, que a rigor residem 'no resguardo da mulher no lar', utilizadas para justificar a proibição do trabalho extraordinário e noturno. ${ }^{257}$

Dessa forma, observamos que este tipo de regulação restritiva do trabalho das mulheres, que imperou em todo o mundo ocidental até praticamente os anos 1980, possuía um caráter muito mais opressor que humanitário. Corrobora este entendimento o fato de que, à época, a exploração da força de trabalho masculina ocorria tanto quanto da feminina, porém sem receber o mesmo tipo de tratamento jurídico, somado ao fato da percepção de que os salários mais baixos pelas mulheres poderiam determinar um aumento do desemprego entre os homens, ameaçando a lógica burguesa do chefeprovedor da família. ${ }^{258}$

A legislação protecionista, portanto, serviu de instrumento para perpetuação da discriminação das mulheres no mercado de trabalho, o que foi abertamente reconhecido no Brasil quando o, já mencionado, Decreto-Lei nº 2.548 , de 1940, permitiu a redução de até $10 \%$ dos salários das mulheres em relação ao dos homens. O Ministro do Trabalho, Indústria e Comércio, Valdemar Falcão, justificou a medida alegando que a obrigação dos estabelecimentos de tomar medidas de higiene e proteção para empregar mulheres, por meio da disponibilização de locais para aleitamento, onera o trabalho feminino, sendo cabível a compensação de tais "encargos" por meio da fixação de salários inferiores. ${ }^{259}$

De modo similar, a proibição do trabalho noturno das mulheres, especialmente na CLT, é predominantemente marcada pelo controle moral das trabalhadoras, bem como pela compreensão de que o labor neste período representava risco à família, pois afastaria essa mulher do lar e de seu papel social de mãe e esposa,

\footnotetext{
${ }^{257}$ BARROS, Alice Monteiro de. A Mulher e o Direito do Trabalho. São Paulo: LTR, 1995. p. 36.

${ }^{258}$ LOPES, Cristiane Maria Sbalqueiro. Direito do trabalho da mulher: da proteção à promoção. Cadernos Pagu, Campinas, n. 26, p. 405-430, 2006. p. 410-411.

259 BARROSO, Carmem. Trabalho e Saúde da Mulher. Revista Brasileira de Saúde Ocupacional, Ministério do Trabalho / Fundacentro, v. 38, n. 10, p. 7-11, abr/mai/jun.1982.
} 
uma vez que ela não estaria em casa para receber o marido e cuidar dos filhos durante a noite. Nesse sentido, Lea Elisa Silingowschi Calil afirma que

(...) a mulher que necessitava trabalhar à noite estava sujeita ao julgamento sobre sua retidão moral. Mas não era apenas a moral dessa mulher que estava na mira do legislador. Dificultar a utilização de mão-de-obra feminina nos períodos noturnos era garantir que a operária, se já fosse ou viesse a ser mãe, estaria em casa em horários compatíveis com a criação de filhos. Mas, também, negava-lhe o acesso a uns tantos postos de trabalho. Na verdade, não havia qualquer explicação científica para se restringir o trabalho feminino noturno, apenas acentuava a divisão sexista das atividades desempenhadas por homens e mulheres."

A ausência de real preocupação com a proteção das mulheres trabalhadoras é facilmente percebida na insistente inclusão de exceções à regra consolidada. Evidente que as situações "excepcionais" previstas pelo artigo 374 não tinham justificativa relacionada à saúde ou à segurança das mulheres, sendo apenas brechas criadas em setores que necessitavam da força de trabalho feminina e onde elas não seriam concorrentes diretas dos homens. As exceções diziam respeito a "trabalhos femininos", como o telemarketing, os serviços de saúde e cuidado, o magistério e o trabalho bancário. Outras, eram de ordem claramente econômica, uma vez que não há diferença para o impacto no organismo de uma mulher trabalhando em indústria de calçados que mantivesse ou não contratos de exportação. O mesmo raciocínio se aplica para a proibição da realização de jornada extraordinária por mulheres sem atestado médico que autorizasse.

Já a vedação do emprego de mulheres em trabalhos insalubres, perigosos, subterrâneos, em pedreiras ou em obras de construção, baseava-se no argumento da fragilidade do organismo feminino, principalmente em relação à maternidade, uma vez que as mulheres, antes de trabalhadoras, eram vistas como mães em potencial. Contudo, vale ressaltar, nas palavras de Anita Brumer, que

(...) em determinados períodos do ciclo industrial ou em determinadas circunstâncias, como durante as guerras e nos períodos de ascensão dos ciclos econômicos, as mulheres são levadas a participar mais ativamente do mercado de trabalho, mesmo em setores antes considerados como predominantemente masculinos, e que são despedidas ou levadas a retornar às atividades domésticas em outras ocasiões. (...) O Estado, com frequência, toma parte ativa na formulação e implementação (ou anulação) de leis e serviços

\footnotetext{
${ }^{260}$ CALIL, Léa Elisa Silingowschi. História do direito do trabalho da mulher: aspectos históricosociológicos do início da República ao final deste século. São Paulo: LTr, 2000. p. 42.
} 
institucionais que favorecem ou desestimulam a participação das mulheres na força de trabalho. ${ }^{261}$

$\mathrm{Na}$ mesma lógica, a previsão do direito a um local de trabalho com as devidas instalações sanitárias e ventilação na CLT direcionava-se apenas para as mulheres, proteção específica sem sentido, uma vez que o meio ambiente de trabalho saudável é medida de dignidade humana, tendo sido posteriormente estendido a todos os trabalhadores.

Importante também destacar que a proteção ao trabalho das mulheres do período não era universal, mas tinha cor e classe social. As mulheres brancas de classe média, impactadas pela legislação, eram incentivadas a assumir seu papel de "donas de casa" ou a desempenhar profissões consideradas femininas, como a enfermagem, a costura e o magistério. Por outro lado, as mulheres de classe baixa, predominantemente não brancas, não tinham opção a não ser continuar trabalhando, meio de sustento para si e sua família, sofrendo de forma mais drástica a desvalorização do trabalho feminino e sendo impelidas a aceitar formas precárias de trabalho, como a informalidade. ${ }^{262}$

Desse modo, se o objetivo da legislação era defender as trabalhadoras contra abusos no trabalho, acabou por corroborar com a bipolarização do emprego feminino, pois condenou as mulheres pobres, que têm na relação de trabalho o seu meio de sobrevivência, a aceitar empregos cada vez mais precários e menos remunerados, que burlassem as proibições. Assim, o surgimento de dois polos de atividade feminina clivados pela condição de classe foi favorecido: o primeiro abrigando ocupações de má qualidade, informais e sem proteção; e o segundo composto por altos cargos, de elevada formação e altas remunerações, mas que também não está livre da discriminação. ${ }^{263}$

A CF, como já dito, é o marco de superação do paradigma jurídico que legitimava a organização patriarcal e da mudança de percepção do trabalho das mulheres, trazendo consigo uma nova concepção de igualdade entre os sexos, não apenas formal, mas material. Desaparece, assim, "a figura da chefia da sociedade

\footnotetext{
${ }^{261}$ BRUMER, Anita. O sexo da ocupação: Considerações teóricas sobre a inserção da mão de obra feminina na força de trabalho. Revista Brasileira de Ciências Sociais, v. 3, n. 8, São Paulo, out. 1988. Disponível em: <http://portal.anpocs.org /portal/index.php?option=com_ content\&view =article\&id=229:rbcs-08\&catid=69: rbcs\&Itemid=399\#2>. Acesso em: 3.ago.2014.

${ }^{262}$ CALIL, Léa Elisa Silingowschi. História do direito do trabalho da mulher: aspectos históricosociológicos do início da República ao final deste século. São Paulo: LTr, 2000. p. 47.

${ }^{263}$ BRUSCHINI, Cristina; LOMBARDI, Maria Rosa. A bipolaridade do trabalho feminino no Brasil contemporâneo. Cadernos de Pesquisa.n. 110. p. 67-104. julho/2010. p. 100.
} 
conjugal e com ela as preferências e privilégios que sustentavam juridicamente a dominação masculina". ${ }^{264}$ Desdobramento desse processo, revogam-se as proibições que impediam a alocação de mulheres em determinados serviços, restando mantidas apenas as distinções normativas referentes à maternidade e ao carregamento de peso, que serão discutidas no momento oportuno.

No entanto, é necessário contextualizar essa nova ordem constitucional e os avanços na legislação trabalhista. Nos anos 1980, houve grande alteração no cenário laboral do país devido à estagnação econômica, que provocou a diminuição de postos de trabalho na indústria e o aumento dos trabalhadores informais ou autônomos, ao mesmo tempo em que o setor terciário se expandia. Desse modo, a conjuntura de redução do emprego e da renda masculina e de abertura das portas do comércio e do setor de serviços empurrou as mulheres de classe média de volta ao mercado de trabalho. Este processo precisou de atento acompanhamento por parte do Direito do Trabalho.

Resta evidente que a criação de uma tutela especial do trabalho das mulheres é uma construção histórica, que evoluiu ao longo do tempo de acordo com o contexto social e as demandas econômicas e políticas do sistema. Concordamos com a análise de Homero Batista Mateus da Silva, de que "a presença ou ausência da mulher no mercado de trabalho tem muito mais que ver com os desígnios do capitalismo do que propriamente com uma questão de segurança e saúde do trabalho". ${ }^{265}$

Assim, se durante a Revolução Industrial era comum que as mulheres trabalhassem inclusive em serviços insalubres e penosos, com o passar do tempo, "talvez por excesso de mão de obra, talvez por temer a concorrência mais capacitada das mulheres, o legislador - normalmente um homem, é sempre bom lembrar - afastou sistematicamente a mulher do mercado de trabalho". À atual conjuntura do sistema interessa um maior volume de força de trabalho, vista como consumidora em potencial e formadora do exército de reserva, de modo que "reinserir a mulher no mercado de trabalho se tornou uma compulsão do legislador" a fim de garantir também a pressão para o achatamento de salários. ${ }^{266}$

\footnotetext{
${ }^{264}$ LOPES, Cristiane Maria Sbalqueiro. Direito do trabalho da mulher: da proteção à promoção. Cadernos Pagu, Campinas, n. 26, p. 405-430, 2006. p. 407.

${ }^{265}$ SILVA, Homero Batista Mateus da. Direito do Trabalho Aplicado, vol. 3: Segurança e medicina do trabalho, trabalho da mulher e do menor. Rio de Janeiro: Elsevier, 2009. p. 154-155.

${ }^{266}$ Ibid., p. 154-155.
} 
Dessa forma, mesmo diante de uma legislação que aparentemente combate a discriminação e visa à promoção da igualdade, é preciso que nos atentemos às regras ainda vigentes, já que, sendo o Direito uma construção político-social-cultural, com forte carga econômica, ele ainda carrega o legado sexista da civilização grecoromana, de modo que "juristas ainda hoje tendem a enxergar a mulher no espaço privado, relutando em aceitá-la nos espaços públicos, e reafirmando insistentemente sua inferioridade e sua submissão". ${ }^{267}$

Portanto, não podemos perder de vista que o Direito reproduz o androcentrismo, pois foi construído sobre concepções masculinas de poder. Nosso papel é de revelar o biologicismo e sexismo presente nas normas que se pretendem protetoras das trabalhadoras, a fim de possibilitar que o paradigma da igualdade seja, de fato, incorporado ao ordenamento jurídico. Nesse sentido, levamos conosco o ensinamento de Márcio Tulio Viana: "Há pelo menos dois modos de discriminar. Pode-se discriminar ferindo regras, mas também com as próprias regras". 268

\subsection{A falsa neutralidade dos conceitos em saúde e segurança}

A despeito dos avanços observados desde 1988 no ordenamento jurídico brasileiro, que passam pela solidificação dos direitos civis das mulheres e pela garantia da não discriminação entre os sexos, nota-se uma relativa estagnação dos direitos referentes à saúde e segurança das trabalhadoras, que praticamente se restringiram à revogação das restrições ao trabalho feminino. Não há dúvidas da importância de tais revogações para a igualdade de gênero no trabalho, conforme analisado ao longo deste capítulo, mas pouco se tem debatido sobre o tema, que, de modo geral, fica reduzido à proteção da maternidade.

Dessa forma, a tutela da saúde e segurança no trabalho continua quase que inteiramente baseada em normas que tratam de trabalhadoras e trabalhadores como uma categoria única. Apesar de esta normativa tutelar homens e mulheres de maneira aparentemente igual, ela foi construída sob a mentalidade sexista que considera o

${ }^{267}$ BERTOLIN, Patrícia Tuma Martins; CARVALHO, Suzete. A segregação ocupacional da mulher: será a igualdade jurídica suficiente para superá-la? In: BERTOLIN, Patrícia Tuma Martins; ANDREUCCI, Ana Claudia Pompeu Torezan (org). Mulher, sociedade e direitos humanos. São Paulo: Rideel, 2010. p. 179-210.

${ }^{268}$ VIANA, Márcio Túlio. Os dois modos de discriminar e o futuro do direito do trabalho. In: VIANA, Márcio Túlio; RENAULT, Luiz Otávio Linhares (coord.). Discriminação. São Paulo: LTr, 2000. p. 321328. p. 321. 
homem como modelo universal de ser humano, enquanto a mulher é vista como "o outro", o especial, o desviante. ${ }^{269}$ Sendo assim, se é a perspectiva de gênero que permite perceber a naturalização das diferenças entre os sexos, como visto anteriormente, também é ela que possibilita revelar as diferenças quando a aparente neutralidade serve de escudo para manutenção da desigualdade.

Sobre isso, Érica Melo explica que o indivíduo abstrato é a essência comum da humanidade, porém, a individualidade só pode se referir a um tipo singular e invariável, de modo que essa abstração gera a exclusão de quem não possui as características exigidas para ser esse protótipo de indivíduo". ${ }^{270}$ Destarte, o conceito de indivíduo abstrato "generaliza, e ao mesmo tempo invoca, uma noção única de indivíduo e a unicidade exige uma relação de diferença que a ideia de indivíduo pretendia negar”, não abrindo espaço para a variedade de indivíduos. As mulheres, que consequentemente não correspondem ao tal protótipo de indivíduo, passa a ser "o outro que confirmava a individualidade". A masculinidade, portanto, torna-se pré-requisito para a ideia de indivíduo. ${ }^{271}$

Uma reflexão cuidadosa nos faz reconhecer que as "as categorizações universais sempre são excludentes, legitimando os já legitimados e colocando à margem aqueles(as) que não se “enquadram" em suas referências". ${ }^{272}$ No entanto, esse estereótipo de que a linguagem e os símbolos masculinos abarcam também o feminino, mas nunca o inverso, está impregnado em nossa cultura, interferindo, inclusive, em uma dinâmica mental que masculiniza as patologias. ${ }^{273}$ Segundo Maria Fernanda Gonzáles Gómez,

Como en casi todos los medios, el uso del lenguaje sexista y androcéntrico está extendido también en el campo de la medicina, y el mundo de la salud laboral no queda exento. Están sólidamente arraigados los estereotipos que mantienen que lo "neutral" (quiere ser entendido como científicamente correcto) es no buscar la

\footnotetext{
${ }^{269}$ AQUINO, Estela M. L. Gênero e saúde: perfil e tendências da produção científica no Brasil. Revista de Saúde Pública, São Paulo, n. 40, p. 121-132, 2006. p. 122.

${ }^{270}$ MELO, Érica. Feminismo: velhos e novos dilemas uma contribuição de Joan Scott. Cadernos Pagu, Campinas, n. 31, p. 553-564, 2008. p. 555.

271 Ibid., p. 556.

${ }^{272}$ LOURO, Guacira Lopes. Nas redes do conceito de gênero. In: LOPES, Marta Julia Marques; MEYER, Dagmar Estermann; WALDOW, Vera Regina. Gênero \& Saúde. Porto Alegre: Artes Médicas, 1996. p. 718. p. 15.

${ }^{273}$ GONZÁLES GÓMEZ, Maria Fernanda. Salud laboral y género: Apuntes para la incorporación de la perspectiva de género en el ámbito de la prevención de riesgos laborales. Medicina y Seguridad del trabajo [online], v. 57, supl.1, p. 89-114, 2011. p. 109.
} 
diferencia por sexos, obviando que lo que se propone y mantiene como modelo es únicamente lo masculino, como si lo femenino fuese una variable de ello, y no como si ambos fuesen dos posibilidades de igual peso para el ser humano". ${ }^{274}$

É possível notar que as pesquisas sobre riscos aos quais estão expostos trabalhadores e trabalhadoras, em sua maioria, excluem as mulheres, mesmo que elas sejam maioria naquele espaço laboral. Ademais, as especificidades corporais e culturais das trabalhadoras são poucas vezes consideradas nas ações de promoção prevenção de acidentes e doenças ocupacionais. Isso demonstra que profissionais de saúde e segurança no trabalho têm construído o conhecimento da área "a partir de uma visão do trabalhador do sexo masculino". 275

Essa cultura tem origem no surgimento da medicina do trabalho, no contexto da Revolução Industrial, centrada na figura autoritária do médico que tinha como missão a defesa dos interesses do capital, o que significou a medicalização do controle social. No caso das mulheres, que exerciam atividades que não eram consideradas produtivas e tampouco arriscadas, o controle médico sobre seus corpos era ainda mais rígido, intervindo sobre sua sexualidade e reprodução. "Foi nesse período, com a consolidação do taylorismo, que a máxima da proteção do corpo se concretizou. (...) Um corpo multiplamente lesado, normatizado, medicalizado e assexualizado". 276

Desse modo, se "a definição de risco em saúde e trabalho sempre foi feita a partir do masculino", ${ }^{277}$ os riscos à saúde e à segurança das mulheres trabalhadoras têm sido historicamente subestimados, de modo que os padrões de saúde e os limites de exposição ocupacionais tomam como parâmetro as populações masculinas e exames laboratoriais. Assim, ignoram-se aspectos sociais e culturais que concorrem para a saúde e abordam-se as especificidades de homens e mulheres com foco apenas nos sistemas reprodutivos de cada sexo ou, ainda, em supostas diferenças psicológicas.

\footnotetext{
${ }^{274}$ GONZÁLES GÓMEZ, Maria Fernanda. Salud laboral y género: Apuntes para la incorporación de la perspectiva de género en el ámbito de la prevención de riesgos laborales. Medicina y Seguridad del trabajo [online], v. 57, supl. 1, p. 89-114, 2011. p. 109.

${ }^{275}$ BONCIANI, Mario. Normas Regulamentadoras e a questão de gênero no trabalho. In: INSTITUTO LATINOAMERICANO DE EDUCAÇÃO INTEGRAL. Um olhar de gênero na saúde e segurança no trabalho, ILEI, São Paulo, nov. 2005. p. 24-25.

${ }^{276}$ OLIVEIRA, Eleonora Menicucci de. Corpos saudáveis e corpos doentes na nova organização social do trabalho. In: ROCHA, Maria Isabel Baltar da. (org). Trabalho e Gênero: Mudanças, Permanências e Desafios. São Paulo: Editora 34, 2000. p. 237-256.

${ }^{277}$ FARIA, Nalu. Apresentação. In: BARRETO, Margarida; CARLOTO, Cássia Maria; COSTA, Maria Luiza da. Saúde das Trabalhadoras. São Paulo: SOF Sempreviva Organização Feminista, 1998. p. 7-8. p. 7.
} 
Somente na década de 1990 começaram a ser desenvolvidas pesquisas sobre o tema incorporando o enfoque de gênero, buscando demonstrar que as diferenças entre trabalhadores e trabalhadoras derivam principalmente da variabilidade humana individual, não de diferenças biológicas entre os sexos. Revelou-se, assim, que os diferentes padrões de adoecimento das mulheres decorrem, essencialmente, "dos riscos relacionados ao trabalho enfrentado por elas, considerando o tipo específico de trabalho que executam e os múltiplos papéis que desempenham na sociedade". 278

Entretanto, ainda hoje, predomina a concepção de trabalho, sua organização e seus equipamentos baseados no modelo de homem médio. Isso vale especialmente para os conhecimentos sobre saúde e segurança ocupacionais, principalmente na esfera jurídica, derivados da experiência de obreiros do sexo masculino, apesar de sempre lançar mão do supostamente neutro plural "trabalhadores", consolidando a invisibilidade das mulheres nessa esfera.

Essa falsa neutralidade, que veladamente carrega parâmetros de proteção à saúde e segurança de homens, brancos, adultos e saudáveis, pode ser notada em nosso ordenamento, por exemplo, nas NR, que fazem pouca ou nenhuma menção às diferenças, mesmo físicas, entre homens e mulheres. Merecem destaque a NR 6 e a NR 12, que não mencionam a necessidade de adequação dos EPI, das máquinas e equipamentos industriais às diferenças corporais entre os sexos (e entre todos os indivíduos).

Ademais, a maioria dos programas empresariais de prevenção a acidentes e doenças laborais atém-se apenas às atividades dos trabalhadores e das trabalhadoras no ambiente de trabalho, ignorando que a vida do ser humano é indivisível, de modo que suas tarefas e compromissos externos são influência direta para o bem-estar no trabalho. Fato é que os riscos no trabalho estão ligados à fadiga acumulada, especialmente no caso das mulheres, sobrecarregadas pela jornada estendida por conta dos intermináveis afazeres domésticos.

Desse modo, observamos a necessidade de reexame dos padrões de risco e segurança e de elaboração de novos processos de trabalho e equipamentos de segurança, para atender devidamente as mulheres trabalhadoras. ${ }^{279}$ No entanto, tais

278 ORGANIZAÇÃO INTERNACIONAL DO TRABALHO. Módulo de capacitação em inspeção do trabalho e igualdade de gênero. Brasília: OIT, 2012. p. 70-71.

${ }^{279}$ HOFMEISTER, Vera Anna. Estudo do término de gestações de trabalhadoras em indústrias. Revista Brasileira de Saúde Ocupacional, Ministério do Trabalho / Fundacentro, v. 38, n. 10, p. 38-42, abr/mai/jun. 1982. 
alterações somente surtirão o efeito desejado se vierem aliadas a medidas sociais que possibilitem a redução das responsabilidades familiares que recaem sobre as mulheres, por meio da instalação de serviços sociais como creches, maternais e lavanderias coletivas.

Portanto, as ações de prevenção e promoção do ambiente laboral sadio e seguro seguirão inócuas às trabalhadoras se não abandonarem sua postura supostamente neutra e sua visão restrita ao local de trabalho, uma vez que, enquanto permanecer a divisão sexual do trabalho, "as mulheres serão mais vulneráveis aos problemas de saúde causados por más condições de trabalho, pois, via de regra, receberão uma 'dose dupla' de agentes agressivos à sua saúde". 280

Esta compreensão da necessidade de que as normas e as políticas de saúde e segurança no trabalho tenham uma base concreta e sejam sensíveis à realidade cultural que vivenciam trabalhadores e trabalhadoras será nosso norte para a análise das diferentes abordagens sobre a proteção das mulheres no trabalho. Nesse sentido, o primeiro enfoque será a tutela da maternidade pelo Direito do Trabalho, na tentativa de demonstrar as contradições e as falhas do sistema normativo que rege a matéria.

\footnotetext{
${ }^{280}$ BARROSO, Carmem. Trabalho e Saúde da Mulher. Revista Brasileira de Saúde Ocupacional, Ministério do Trabalho / Fundacentro, v. 38, n. 10, p. 7-11, abr/mai/jun.1982. p. 10.
} 


\section{Capítulo 3. Maternidade, saúde e segurança no trabalho}

\section{1. "Você vai parar pra ter filho?"}

A maciça entrada das mulheres no mercado de trabalho não teve como contrapartida o suficiente aumento da presença dos homens na esfera doméstica, de modo que a divisão sexual do trabalho foi mantida, com raras exceções, conforme tratado no capítulo 1. Apesar de terem ocorrido "modificações na repartição do trabalho doméstico", com uma "maior participação dos homens" em comparação com décadas passadas, essa mudança "tem um caráter restrito e tópico e não atinge o âmbito das responsabilidades domésticas, que continuam a ser atribuídas exclusivamente às mulheres". 281

Por conseguinte, a presença das mulheres no mundo do trabalho ainda é definida "pelas condições que elas têm para conciliar trabalho assalariado, papel na família, trabalho doméstico e cuidado com os filhos e maridos", ${ }^{282}$ processo em que a maternidade é elemento central. Assim, a sobrecarga das responsabilidades familiares e, sobretudo, da maternidade, constituem obstáculo para a integração e permanência das mulheres na esfera produtiva. ${ }^{283} \mathrm{O}$ impacto do nascimento de uma criança sobre a carreira profissional acaba por determinar o afastamento das mulheres de seu emprego, tanto provisória quanto definitivamente, ou a busca por flexibilização e redução da jornada, a fim de conseguirem exercer seu papel de provedoras do cuidado.

Inclusive, necessário frisar que a ideia de conciliação harmoniosa entre vida profissional e vida familiar é uma falácia, fonte de angústia e conflito para as mulheres. O que se vê na prática é que as mulheres sofrem para fazer esta conciliação, que em momento algum é proposta também para os homens, impedindo o compartilhamento de tarefas. Se o conflito quanto à necessidade de somar as responsabilidades é amortecido, isso se deve à transferência, ou terceirização, de parte

\footnotetext{
${ }^{281}$ HIRATA, Helena. Reorganização da produção e transformações do trabalho: uma nova divisão sexual do trabalho? In: BRUSCHINI, Cristina; UNBEHAUN, Sandra (orgs.). Gênero, democracia e sociedade brasileira. São Paulo: FCC, 2002. p. 339-355. p. 350.

${ }^{282}$ FARIA, Nalu. Apresentação. In: BARRETO, Margarida; CARLOTO, Cássia Maria; COSTA, Maria Luiza da. Saúde das Trabalhadoras. São Paulo: SOF Sempreviva Organização Feminista, 1998. p. 7-8. p. 7.

283 AGUILERA IZQUIERDO, Raquel. Los derechos de conciliación de la vida personal, familiar y laboral en la Ley Orgánica para la igualdad efectiva de mujeres y hombres. Revista Del Ministerio De Trabajo y Asuntos Sociales, Madrid, n. extra 2, p. 69-119, 2007. p. 69.
} 
do trabalho de cuidado a outras mulheres, como empregadas domésticas, e cuidadoras. $^{284}$

Dessa forma, não resta saída à maioria das mulheres senão escolher entre a carreira ou a maternidade, uma vez que, diante das responsabilidades familiares a elas atribuídas, tais alternativas são praticamente excludentes. Essa realidade faz com que muitas mulheres brasileiras, hoje em dia, sigam a via da recusa da maternidade, o que é representado em termos numéricos pela queda das taxas de natalidade: em 2011, a taxa de fecundidade para o Brasil era de 1,95 filho por mulher, em contraponto à taxa de 4,4 filhos por mulher, na década de $1980 .{ }^{285}$ A necessidade de planejamento familiar é demonstrada também pela taxa de $25,9 \%$ de mulheres brasileiras que interrompem definitivamente a opção da maternidade, o que é feito cada vez mais cedo: $12,4 \%$ das mulheres entre 25 e 29 anos e $26,7 \%$ daquelas entre 30 e 34 anos são cirurgicamente estéreis.

Outro fato que demonstra com clareza o peso para as mulheres da conciliação entre trabalho remunerado e cuidado dos filhos e filhas pequenos é o impacto da licença-maternidade remunerada nos índices de permanência de mães no emprego. Dentre os únicos três países que ainda não possuem regulamentação sobre a obrigatoriedade da licença-maternidade para trabalhadoras, ${ }^{286}$ os Estados Unidos registram grandes dificuldades de aumentar as taxas de participação feminina na força de trabalho. No entanto, o resultado da oferta de salário-maternidade como direito das trabalhadoras pode ser visto em alguns exemplos:

After California became the first state to offer paid parental leave, new mothers were more likely to return to work (...) One to three years later, mothers of small children were working more and at higher incomes. Paid leave provides job continuity, economists say, so women are less likely to leave the labor force. Paid leave is particularly important for low-income mothers, who more than doubled their maternity leaves in California. (...) Google is another real-world case study. Postpartum women were leaving the company at a rate twice that of other employees. So Google expanded its

\footnotetext{
${ }^{284}$ HIRATA, Helena. O trabalho do cuidado (care) em perspectiva comparada: França, Japão e Brasil.In: ABREU, Maria Aparecida (org). Redistribuição, reconhecimento e representação: Diálogos sobre igualdade de gênero. Brasília: IPEA, 2011. p. 83-107. p. 84.

${ }^{285}$ BRASIL. Relatório Anual Socioeconômico da Mulher 2013. Brasília: Secretaria de Políticas para as Mulheres, 2013. p. 24.

${ }^{286}$ Segundo o mais atual relatório da OIT sobre maternidade no trabalho, dos 185 países e territórios com informações disponíveis sobre o tema, apenas Oman, Papua-Nova Guiné e Estados Unidos não possuem previsão legal geral sobre auxílios em dinheiro durante a licença-maternidade. Em: ADDATI, Laura; CASSIRER, Naomi; GILCHRIST, Katherine. Maternity and paternity at work: law and practice across the world. Genebra: OIT, 2014. p. 16.
} 
maternity leave to five months fully paid from three months partly paid. Attrition decreased by 50 percent. ${ }^{287}$

No entanto, além das imposições socioeconômicas que levam as trabalhadoras a adiarem a escolha de serem mães ou recusá-la, é preciso destacar a influência do significado social da maternidade na vida das mulheres. Em nossa sociedade, a maternidade ainda é vista como sagrada, formada pela visão da gravidez como estado de graça e pela crença na natural felicidade materna, de modo que dificilmente há abertura para ser problematizada. Disso decorre uma forte cobrança sobre as mulheres, que muitas vezes as impede de exercer uma livre escolha em relação à maternidade, seja consciente ou inconscientemente.

Tomamos como referência a análise de Elisabeth Badinter, que atribui historicidade à maternidade, de modo a desmistificá-la. Segundo ela, o amor materno é construído socialmente, como forma de controle e submissão das mulheres às necessidades sociais de cuidado e educação das crianças. O instinto materno é um mito, uma vez que não é possível encontrar nenhuma conduta universal e necessária a todas as mães, que, ao contrário, possuem uma grande variabilidade de sentimentos, o que depende de cada mãe, da sua história e da História. "Não, não há uma lei universal nessa matéria, que escapa ao determinismo natural. $\mathrm{O}$ amor materno não é inerente às mulheres. É adicional". ${ }^{288}$

Conforme demonstra a autora, após uma detalhada pesquisa histórica sobre a maternidade no ocidente, foi no último terço do século XVIII que ocorreu uma mudança radical na imagem e no papel da mãe na criação das crianças. Se antes se insistia no valor e na centralidade da autoridade paterna, pois importava criar súditos dóceis ao poder do Rei, no final do século XVIII, com os novos valores trazidos pela mudança da conjuntura política, passa a importar a produção de seres humanos que serão a riqueza do Estado. O foco ideológico se desloca da autoridade do pai para o amor da mãe. ${ }^{289}$

Neste período, abundam publicações, dentre as quais as de Jean-Jacques Rousseau, que recomendam às mães que cuidem pessoalmente das crianças e que

\footnotetext{
${ }^{287}$ MILLER, Claire Cain. Paid Leave Encourages Female Employees to Stay. The New York Times, New York, 28.jul.2014. Disponível em: < http://www.nytimes.com/2014/07/29/upshot/how-paid-leave-helpsfemale-employees-stay-.html?_r=0\&abt=0002\&abg=1>. Acesso em: 15.ago.2014.

${ }^{288}$ BADINTER, Elisabeth. Um amor conquistado: $O$ mito do amor materno. Rio de Janeiro: Nova Fronteira, 1985. p. 366.

${ }^{289}$ Ibid., p. 145-146.
} 
ordenam que elas próprias amamentem, impondo às mulheres a obrigação de serem mães antes de tudo e engendrando o mito do instinto materno ou amor espontâneo que toda a mãe teria por seu filho ou filha. ${ }^{290}$

A evolução dos costumes foi lenta. Não por acaso, as primeiras mulheres a aderirem ao discurso masculino sobre a maternidade foram burguesas, que viram nessa nova função uma oportunidade de elevação social, uma vez que elas assumiam para si o poder sobre a casa e a família, sendo as "novas mães". Em contrapartida, as mulheres mais favorecidas da aristocracia e as mulheres mais pobres resistiram a se conformar com o novo modelo. As operárias e esposas de artesãos precisavam, no final do século XVIII, mais do que nunca, mandar as crianças para o campo para poder trazer mais alguma renda para casa. A atenção materna era "um luxo que as mulheres pobres não se podem permitir". ${ }^{291}$

Entretanto, ainda que o discurso de Rousseau e seus sucessores não tenha conseguido que todas as mulheres se tornassem mães dedicadas, gerou sobre elas um efeito devastador: "as mulheres se sentiram cada vez mais responsáveis pelos filhos", de modo que aquelas que se recusavam a obedecer aos novos ditames do papel materno, trapaceavam e simulavam ser mães devotadas. Assim, "quando não podiam assumir seu [suposto] dever, consideravam-se culpadas". Foram vitoriosos os que pregavam esse novo papel materno, pois "a culpa dominou o coração das mulheres". ${ }^{292}$

Nesse contexto, a maternidade adquiriu um sentido mais amplo de modo que, enriquecida de novos deveres, ela passa a ser muito mais do que os nove meses de gestação. No século XIX, soma-se à nova concepção moralizadora da mãe o discurso da psicanálise, que torna a mãe a grande responsável pela felicidade e equilíbrio psíquico de sua cria: "enclausurada em seu papel de mãe, a mulher não mais poderá evitá-lo sob pena de condenação moral". ${ }^{293}$

Diante do panorama histórico da construção social da maternidade, Elisabeth Badinter atesta que "duzentos anos de ideologia materna e o desenvolvimento do processo de 'responsabilização' da mãe modificaram radicalmente as atitudes”, de modo que, as mulheres dos séculos XX e XXI, mesmo quando trabalham, "permanecem

\footnotetext{
${ }^{290}$ BADINTER, Elisabeth. Um amor conquistado: $O$ mito do amor materno. Rio de Janeiro: Nova Fronteira, 1985. p. 146, 201.

${ }^{291}$ Ibid., p. 213-224.

292 Ibid., p. 235.

${ }^{293}$ Ibid., p. 237-238.
} 
infinitamente mais próximas dos filhos e preocupadas com eles do que as de outrora". Ainda assim, as mulheres que se recusam a sacrificar suas carreiras e ambições pelo bem-estar da prole são demasiadamente numerosas para serem classificadas como exceções patológicas de um suposto comportamento materno natural. ${ }^{294}$

Hoje em dia, diferente do século XVIII, na sociedade em que a mortalidade infantil está em seu menor nível, os argumentos para a devoção e dedicação das mães à prole mudaram: não é mais a sobrevivência da criança que está em jogo, mas a sua saúde física e psíquica, bem como a harmonia social. Investe-se na ideia de que uma boa mãe "naturalmente" coloca as necessidades do filho ou filha acima de tudo. A face oposta da moeda é a consequente culpa sentida pelas mães que não se reconhecem no papel de completa doação à criança, e estigmatização daquelas que preferem voltar ao trabalho, ou que optam por dar mamadeira ao invés de continuar a amamentação. ${ }^{295}$

É este contexto que faz com que as mulheres vivenciem, quando tentam conciliar o trabalho remunerado com o cuidado das crianças e da casa, "o sentimento de culpa por "descuidar dos seus", sendo constantemente responsabilizadas por parte de seus maridos". ${ }^{296}$ Assim, as trabalhadoras experimentam situações dilacerantes diante da necessidade de escolha entre dedicação à profissão e maternidade, sendo que, quando optam pela segunda, novamente se deparam com a necessidade de escolha entre aleitamento e desmame precoce. ${ }^{297}$

Portanto, não só o processo de escolha entre maternidade e trabalho é doloroso para as mulheres, como também o retorno ao trabalho após o nascimento da criança, pois é vivido com a angústia de deixar o bebê sob responsabilidade de outrem. Em relação à amamentação, por exemplo, o medo de perder o emprego ou a possibilidade de promoção induz as trabalhadoras à interrupção precoce do aleitamento, "vivendo situações de ansiedade e medo, que possivelmente desencadearam processos destrutivos em sua saúde psíquica". ${ }^{298}$

\footnotetext{
${ }^{294}$ BADINTER, Elisabeth. O conflito: a mulher e a mãe. Rio de Janeiro: Record, 2011. p. 343.

${ }^{295}$ Ibid., p. 78-98.

${ }^{296}$ BARRETO, Margarida Maria Silveira. Violência, saúde e trabalho: uma jornada de humilhações. São Paulo: EDUC, 2013. p. 203.

${ }^{297}$ ARAÚJO, Angela Maria Carneiro; OLIVEIRA, Eleonora Menicucci. Reestruturação produtiva e saúde no setor metalúrgico: a percepção das trabalhadoras. Sociedade e Estado, Brasília, v.21, n.1, p. 169198, 2006. p. 184.

${ }^{298}$ OLIVEIRA, Eleonora Menicucci de. A mulher, a sexualidade e o trabalho. São Paulo: CUT, 1999. p. 122.
} 
Interessante ressaltar que, apesar de o modelo predominante de maternidade variar de acordo com as épocas, conscientemente ou não as mulheres o carregam. Seja para aceitá-lo, negociá-lo ou rejeitá-lo, é sempre em relação a ele que as mulheres são determinadas. ${ }^{299}$ Nereida Salette Paulo da Silveira ilustra essa questão em pesquisa realizada em 2011 com mulheres gerentes, na qual foi constatado que, para alcançarem posições mais elevadas dentro da carreira, tiveram que superar não apenas as barreiras impostas pela divisão sexual do trabalho no contexto organizacional, mas também lidar com a própria identidade de mulher, construída em torno da concepção de maternidade. A autora relata que

(...) a construção social da maternidade e sua oposição ao trabalho revelaram-se como elemento central e naturalizado na forma como as informantes apresentavam a construção da identidade de gênero ao longo do desenvolvimento de suas vidas profissionais até uma posição gerencial. (...) Se a experiência de ser mãe não faz parte da vida de todas informantes, a concepção de maternidade ainda faz. Por exemplo, as mulheres sem filhos, ao se identificarem, fazem-no pela contraposição das suas experiências de vida às das mulheres com filhos.(...) identificam-se como SENDO MULHER MÃE ou SENDO MULHER NÃO MÃE. A centralidade da maternidade para a autodefinição das mulheres tem a forma de um mandato de tal modo que, quando escolhem não ter filhos, vão de encontro às forças sociais e culturais. ${ }^{300}$

A pesquisa indica que tanto as mulheres gerentes com descendentes como as sem descendentes "interpretam a maternidade como uma, senão a principal, concorrente à vida profissional". ${ }^{301}$ Em decorrência do peso da maternidade sobre a identidade dessas mulheres, elas vivem em constante paradoxo: quando têm filhos ou filhas, buscam compensar o suposto prejuízo que a maternidade gera para sua imagem profissional, ao passo que quando optam por não ter filhos ou filhas, sentem-se obrigadas a justificar sua escolha. ${ }^{302}$

\footnotetext{
${ }^{299}$ BADINTER, Elisabeth. O conflito: a mulher e a mãe. Rio de Janeiro: Record, 2011. p. 143.

${ }^{300}$ SILVEIRA, Nereida Salette Paulo da. Mulheres gerentes: a centralidade da maternidade na construção da identidade de gênero no trabalho. In: XXXV Encontro da Associação Nacional de Programas de Pósgraduação e Pesquisa em Administração, 2011, Rio de Janeiro. Anais do EnANPAD 2011. Rio de Janeiro: ANPAD, 2011. p. 6-7.

${ }^{301}$ A frase escolhida para o título deste capítulo reflete o comportamento, especialmente das mulheres de classes mais altas, de, em determinado ponto da carreira, já postergado ao máximo, optarem por engravidar de por "parar" de trabalhar para cumprir seu papel reprodutivo, de mãe. A frase é emblemática porque nunca é direcionada aos homens.

${ }^{302}$ SILVEIRA, Nereida Salette Paulo da. Mulheres gerentes: a centralidade da maternidade na construção da identidade de gênero no trabalho. In: XXXV Encontro da Associação Nacional de Programas de Pósgraduação e Pesquisa em Administração, 2011, Rio de Janeiro. Anais do EnANPAD 2011. Rio de Janeiro: ANPAD, 2011. p. 9-11.
} 
Desse modo, para as mulheres trabalhadoras inseridas no mercado de trabalho, a representação da maternidade é marcada pelo conflito entre o desejo de ser mãe e o sentimento de culpa, como se cometessem um crime pelo qual serão penalizadas, pois "elas sabem que não existe neutralidade na relação empresa e maternidade do ponto de vista da eficácia da produção". ${ }^{303}$

O temor das trabalhadoras de sofrerem preconceito no mercado de trabalho por serem mães não é sem razão, uma vez que os empregadores de fato discriminam mulheres com filhos e filhas, especialmente quando ainda pequenos, ainda que o preconceito seja velado. Cordelia Fine descreve uma reveladora pesquisa sobre o tema:

Inventando que uma empresa de comunicações recém-criada estava procurando um chefe para o departamento de marketing, a socióloga Shelley Correll e colegas descobriram que, em comparação com mulheres fictícias que não eram mães, candidatas fictícias que eram mães, com qualificações idênticas, foram consideradas $10 \%$ menos competentes, $15 \%$ menos comprometidas com o local de trabalho e merecedoras de um salário anual US\$ 11 mil menor. Além disso, somente $47 \%$ das mães, em comparação com $84 \%$ das que não eram mães, foram recomendadas para contratação. (...) Para complementar o estudo, Correll e seus colegas enviaram um total de 1.276 currículos e cartas de apresentação fictícios para empregos autênticos na área empresarial e de marketing anunciadas nos jornais. Foram enviados a cada empregador dois currículos de dois candidatos igualmente qualificados. Ambos eram do mesmo sexo (às vezes os dois eram homens, outras vezes eram mulheres), mas somente um deles era identificado como sendo pai ou mãe. (Os pesquisadores contrabalançaram qual candidato que era o pai ou a mãe). E, seguida, os pesquisaremos relaxaram e esperaram para ver quem receberia mais chamados dos possíveis empregadores. Enquanto a paternidade não atuou nem um pouco como uma desvantagem para os homens, houve evidência de uma substancial 'penalidade à maternidade'. O número de mães chamadas foi apenas a metade do das mulheres sem filhos com qualificações idênticas. ${ }^{304}$

De maneira similar, Lorena Holzmann da Silva, em estudo sobre os requisitos de empregadores e setores de recursos humanos das empresas para recrutamento de pessoal, descobriu que as funções de reprodutora e nutriz e a responsabilidade quase que exclusiva das mulheres pelo cuidado de filhos e filhas geram empecilhos para a contratação, ainda que isso não seja o discurso oficial dos

\footnotetext{
${ }^{303}$ OLIVEIRA, Eleonora Menicucci de. A mulher, a sexualidade e o trabalho. São Paulo: CUT, 1999. p. 120.

${ }^{304}$ FINE, Cordelia. Homens não são de Marte, mulheres não são de Vênus: como a nossa mente, a sociedade e o neurossexismo criam a diferença entre os sexos. São Paulo: Cultrix, 2012. p. 90-91.
} 
empregadores, o que é proibido por força do artigo $1^{\circ}$ da Lei $n^{\circ} .9 .029$, de 1995.

Segundo a autora,

(...) o tipo de tarefa a ser desempenhada foi apontado como o único critério de preferência na admissão de homens ou mulheres. A afirmativa categórica foi sempre a de que, com exceção desta questão, a empresa não dá qualquer preferência por trabalhador de um ou outro sexo, nem no momento da admissão, nem nas possibilidades de melhoria na hierarquia interna da fábrica. Mas as informações prestadas deixam bem claro que existem outros fatores que condicionam as opções de recrutamento de mão-de-obra como, por exemplo, vida profissional anterior, o local de moradia, entre outros. No entanto, quando se trata de avaliar as condições de candidatos do sexo feminino, outras variáveis são levadas em conta na tomada de decisão do empregador (...).

Lorena Holzmann da Silva então relata um depoimento colhido durante a pesquisa, no qual a pessoa entrevistada afirma que, quando uma mulher é candidata ao emprego, observa-se "a estrutura familiar dela, ou seja, se ela tem filhos, qual a idade deles e se ela tem com quem deixá-los. (...) a gente mesmo conversa com ela e diz para procurar alguém com quem possa deixar o filho, se vale a pena financeiramente" e, em seguida, orienta-se a candidata para que volte a pleitear a vaga quando esse problema estiver resolvido. Tal questão, porém, não é colocada quando se trata de candidato do sexo masculino, o que demonstra como o cuidado ainda é uma atribuição considerada feminina, o que somado à precariedade da estrutura pública de guarda das crianças, dificulta o acesso e permanência das mulheres no emprego. ${ }^{305}$

Além disso, o estudo demonstrou que a carga de responsabilidades familiares também influencia na potencialidade das mulheres de conquistarem posições hierárquicas superiores, ainda que o discurso empresarial seja de que as chances de promoção são iguais para todos e todas. As dificuldades enfrentadas pelas mães trabalhadoras, especialmente de crianças pequenas, "criam de fato uma atitude desfavorável do empregador a sua promoção, reforçada pela visão de que a opção entre permanecer no emprego ou abandoná-lo para cuidar dos filhos é uma questão de 'preferência"'. Desse modo, ainda que não admitido explicitamente, o envolvimento das mulheres com as questões domésticas interfere em seu trabalho, sendo muitas vezes

\footnotetext{
${ }^{305}$ SILVA, Lorena Holzmann da. Admitimos mulheres, para trabalhos leves. Estudos Feministas, Florianópolis, v.3, n.2, p.349-361, 1995. p. 356.
} 
usado como justificativa pelos empregadores para o retardamento dos processos de promoção. ${ }^{306}$

Por tudo que foi analisado, é possível concluir que a manutenção da construção da identidade feminina em torno da maternidade condiciona a participação das mulheres no mercado de trabalho, para além de fatores como a oferta de emprego ou da qualificação profissional, uma vez que fatores como o estado conjugal, a presença de filhos, o fato de estar ou não em idade fértil, "afetam a participação feminina, mas não a masculina, no mercado de trabalho". Nas palavras de Cristina Bruschini, a "responsabilidade das mulheres pelos cuidados com a casa e a família é um dos fatores determinantes da posição secundária ocupada por elas no mercado de trabalho". ${ }^{307}$

Desse modo, "a realização da maternidade ainda compromete consideravelmente as mulheres e revela uma face importante da lógica da razão androcêntrica", ${ }^{308}$ separando-as socialmente dos homens, o que gera desequilíbrio laborambiental decorrente da desigualdade de condições de trabalho de mães e pais. Para Elizabeth Souza-Lobo, esse é o ponto mais interessante para a discussão da igualdade e diferença nas relações de gênero:

A vivência da maternidade é uma diferença que atinge mulheres, uma especificidade, ou maternidade e paternidade são vivências de mulheres e homens iguais que compõem uma humanidade que nem é masculina nem é neutra, mas sexuada, e que por isso mesmo implica vivências sexuadas. Assim, é preciso poder viver a maternidade e a paternidade, e se os homens não a vivem é também porque a paternidade só é entendida através da ética do provedor. Não se dá tempo aos homens para que sejam pais. E para que as mulheres sejam mães é preciso que renunciem ao trabalho. Isto não é só porque se considera a licença-maternidade um luxo, mas porque as mulheres não encontram equipamentos coletivos que facilitem as tarefas domésticas: as creches, os parques infantis, as escolas com tempo integral. Por isso é tão difícil ser operária, bancária, médica, professora universitária e (...) avançar nas carreiras. ${ }^{309}$

\footnotetext{
306 SILVA, Lorena Holzmann da. Admitimos mulheres, para trabalhos leves. Estudos Feministas, Florianópolis, v.3, n.2, p.349-361, 1995. p. 358.

307 BRUSCHINI, Cristina. Gênero e trabalho no Brasil: novas conquistas ou persistência da discriminação? In: ROCHA, Maria Isabel Baltar da. (org). Trabalho e Gênero: Mudanças, Permanências e Desafios. São Paulo: Editora 34, 2000. p. 13-58. p. 19. p. 16-19.

${ }^{308}$ SCAVONE, Lucila. A maternidade e o feminismo: diálogo com as ciências sociais. Cadernos Pagu, Campinas, n. 16, p. 137-150, 2001.p. 149-150.

${ }^{309}$ SOUZA-LOBO, Elizabeth. A classe operária tem dois sexos: trabalho, dominação e resistência. 2 ed. São Paulo: Editora Fundação Perseu Abramo, 2011. p. 284.
} 
Essa análise, que nos servirá de base ao longo de todo o capítulo, permite perceber que, em relação à maternidade, o próprio Direito do Trabalho funciona como criador do desequilíbrio labor-ambiental, uma vez que não permite a vivência compartilhada da parentalidade, sobrecarrega as mulheres e abre caminho para a discriminação. É esse tipo de distorção que pretendemos analisar nos próximos itens, para que possamos restabelecer o equilíbrio no meio ambiente do trabalho pela via da igualdade de gênero.

\subsection{A deficiente legislação brasileira de proteção às trabalhadoras-mães}

Como retratado, compreender a maternidade como construção histórica permite que refutemos o determinismo biológico que reserva às mulheres o destino social de mães, revelando que não é a reprodução biológica que estabelece a posição social das mulheres, mas "as relações de dominação que atribuem um significado social à maternidade." 310 Entretanto, os mitos existentes em torno da maternidade foram historicamente apropriados pelas instituições sociais, que "criaram e estimularam outros para reforçar o estado de submissão da mulher, principalmente na questão da maternidade, colocando-a como sua única função e bilhete de acesso ao paraíso". 311

Esse raciocínio vale especialmente para o Direito do Trabalho, que historicamente impõe regras que limitam as possibilidades de escolha das mulheres acerca do exercício da maternidade, alegando a necessidade de tutela das trabalhadorasmães. Ao se "tutelar", estabelece uma relação assimétrica, em que as mulheres são consideradas incapazes de decidir pela própria vida, ao invés de garantir direitos de cidadania às mães trabalhadoras. ${ }^{312}$

A deficiência da legislação brasileira em termos de garantias reprodutivas para as mulheres pode ser constada analisando-se os padrões internacionais. Nesse sentido, na Conferência Internacional de População e Desenvolvimento, realizada no Cairo, em 1994, os direitos reprodutivos foram reconhecidos como direitos humanos, de

\footnotetext{
${ }^{310}$ SCAVONE, Lucila. A maternidade e o feminismo: diálogo com as ciências sociais. Cadernos Pagu, Campinas, n. 16, p. 137-150, 2001. p. 138-141.

${ }^{311}$ SCHIRMER, Janine. Trabalho e maternidade: qual o custo para as mulheres? In: OLIVEIRA, Eleonora Menicucci de; SCAVONE, Lucila. (org). Trabalho, Saúde e Gênero na era da globalização. Goiânia: AB Editora, 1997. p. 101-113.

${ }^{312}$ OLIVEIRA, Eleonora Menicucci de. A mulher, a sexualidade e o trabalho. São Paulo: CUT, 1999. p. $112-113$
} 
modo a garantir "que a pessoa possa ter uma vida sexual segura e satisfatória, tenha a capacidade de reproduzir e a liberdade de decidir sobre quando, e quantas vezes o deve fazer". ${ }^{313}$ De modo complementar, o ponto 223 da Plataforma de Ação de Pequim, de 1995, reafirmou os direitos reprodutivos das mulheres, nos quais foi incluído o direito de decidir livremente sobre a reprodução, sem se sujeitar à discriminação, coerção ou violência. $^{314}$

Fato é que, nos atuais moldes, as normas sobre maternidade no Brasil nem mesmo garantem o direito à livre escolha das mulheres sobre a reprodução, uma vez que não apenas o aborto é ainda uma prática criminalizada, que mata centenas de mulheres no Brasil todos os anos, ${ }^{315}$ como também no que toca o mercado de trabalho, o preconceito dos empregadores contra as trabalhadoras-mães, retratado no tópico anterior, demonstra que em momento algum as brasileiras podem escolher engravidar sem que arquem com a discriminação e suas consequências.

Desse modo, observa-se que a proibição de o empregador tomar como critério a situação familiar da trabalhadora para fins de acesso ou manutenção da relação de emprego, remuneração, formação ou ascensão profissional, de que tratam o artigo 373, da CLT e o artigo $1^{\circ}$, da Lei $n^{\circ} .9 .029$, de 1995, não é suficientemente eficaz, uma vez que, "quando se considera a situação familiar, importa particularmente a existência de filhos, como obstáculo à admissão de mulheres, por serem elas (...) as responsáveis por acompanhá-los aos médicos, o que poderia aumentar a ausência ao serviço". 316

Da mesma maneira, a garantia constitucional de emprego à gestante, apesar de representar uma medida fundamental de combate à desigualdade, não é suficiente para que as mulheres sintam-se seguras no ambiente de trabalho durante a gravidez ou no retorno ao trabalho. Como tratamos anteriormente, a maternidade continua sendo fonte de preconceito por parte dos empregadores, de modo que a

\footnotetext{
${ }^{313}$ FUNDO DE POPULAÇÃO DAS NAÇÕES UNIDAS. Relatório da Conferência Internacional sobre População e Desenvolvimento - Plataforma de Cairo. Brasília: UNFPA, 1994. p. 62.

314 ORGANIZAÇÃO DAS NOÇÕES UNIDAS. Beijing Declaration and Platform for Action. Beijin: ONU, 1995. p. 91. Disponível em: 〈http://www.un.org/womenwatch/daw/beijing/pdf/BDPfA\%20E.pdf>. Acesso em: 10.jun.2013.

${ }^{315}$ O aborto é reconhecido como questão de saúde pública desde a Conferência do Cairo sobre População e Desenvolvimento, de 1994, justamente por conta dos alarmantes índices de mortalidade provocados pela clandestinidade. No caso do Brasil, a OMS estima que sejam feitos, em média, um milhão de abortos clandestinos por ano, sendo que a cada dois dias, uma mulher morre em decorrência do procedimento. Disponível em: <http://ultimosegundo.ig.com.br/brasil/2013-09-20/clandestinas-retratos-do-brasil-de-1milhao-de-abortos-clandestinos-por-ano.html>. Acesso em: 15.ago.2014.

${ }^{316}$ MALLET, Estevão. Igualdade e discriminação em direito do trabalho. São Paulo: LTr, 2013. p. 49.
} 
estabilidade provisória mostra-se insuficiente, uma vez que o sistema em si, sexista, continua desvalorizando as mulheres por conta da reprodução. Consequentemente, se a discriminação das mulheres não se mostra na dispensa por motivo de gravidez, já que a legislação proíbe, a discriminação acontece de outras maneiras e em outras atitudes, veladas em maior ou menor grau.

A insistência legislativa e judiciária de concentrar esforços na proibição da discriminação por motivo de sexo e na garantia de emprego à gestante, ${ }^{317}$ além de gerar pouco mais que efeitos formais, acabou por ocultar que as diferenças de gênero no trabalho são, na verdade, um reflexo dos diferentes papéis atribuídos às mulheres e aos homens dentro da família. ${ }^{318}$ Assim, a determinação legal de que o empregador trate mulheres e homens de forma igual não trará resultados enquanto nosso ordenamento jurídico não abandonar os paradigmas sexistas e biologicistas a respeito da maternidade e do papel das mulheres na família.

O modo como o Direito do Trabalho brasileiro trata o cuidado da prole como de responsabilidade exclusiva da mulher, ignorando a participação do homem e o interesse estatal na reprodução da força de trabalho, reforça o preconceito empresarial na contratação de mulheres, principalmente em idade fértil. Alega-se que o sistema de proteção à maternidade gera custos mais elevados das mulheres em relação aos homens, motivo pelo qual se opta preferencialmente por trabalhadores do sexo masculino.

Dessa forma, muitos empregadores acabam por tratar a gravidez como doença, de modo a enxergar as trabalhadoras gestantes ou mães de filhos pequenos como potenciais prejuízos à sua atividade econômica. Entretanto, uma breve análise dos estudos a esse respeito permite comprovar que isso não corresponde à realidade.

Segundo dados de 2005 da OIT, por exemplo, a incidência anual de gestações entre as trabalhadoras assalariadas é bastante baixa, em torno de 3\%, e os custos derivados da legislação de proteção à maternidade não são financiados por quem as emprega, mas sim pelo sistema previdenciário. Além disso, os tão temidos gastos relacionados à substituição da mulher afastada durante a licença-maternidade tampouco

\footnotetext{
${ }^{317}$ Exemplos nesse sentido são a edição da Lei $\mathrm{n}^{\circ}$. 12.812, de 16 de maio de 2013, que esclareceu que a estabilidade provisória é direito das gestantes mesmo durante o cumprimento do aviso prévio, e na nova redação da Súmula 244 do TST, que interpretou que a garantia também se estende às mulheres admitidas por contrato por tempo determinado.

${ }^{318}$ AGUILERA IZQUIERDO, Raquel. Los derechos de conciliación de la vida personal, familiar y laboral en la Ley Orgánica para la igualdad efectiva de mujeres y hombres. Revista Del Ministerio De Trabajo y Asuntos Sociales, Madrid, n. extra 2, p. 69-119, 2007. p. 69.
} 
se mostram impactantes para os empregadores: o custo monetário direto de substituição representa menos de $0,09 \%$ de sua remuneração bruta no Brasil. ${ }^{319}$

Também o absenteísmo entre as trabalhadoras-mães não passa de um mito. Pesquisa da OIT, realizada em empresas brasileiras dos setores químico e metalúrgico, registrou que o número de ausências e licenças das mulheres foi inferior ao dos homens. Em média, por pessoa, constatou-se que o número médio de licenças anuais concedidas era de 0,9 para as mulheres e 1,6 para homens, bem como que a duração média de dias não trabalhados para elas era de 6,2, enquanto para eles era de 6,5. Ademais, a principal causa das ausências no trabalho entre os dois sexos eram os acidentes de trabalho, que correspondem a mais da metade dos dias afastados. No caso das mulheres, especificamente, a média de dias não trabalhados em decorrência de acidente de trabalho é de 3,2, superando a média de dias não trabalhados em função da licença-maternidade, que é de $2,5^{320}$

As origens da concepção de que uma trabalhadora grávida é trabalhadora doente remontam à construção histórica feita pela medicina das diferenças entre homens e mulheres, que vem desde o século XIX, conforme analisamos no capítulo 1. O corpo masculino era descrito, naquela época, como superior em relação ao feminino, o qual estaria reservado à maternidade e moldado exclusivamente para a gestação e o parto. Assim, tudo que desviava da fisiologia masculina era considerado patológico, de modo que a normal existência das mulheres era, em si, apresentada "como patologia estabelecida, manifestada nas gravidezes e 'hemorragias periódicas"”. 321

Consequência desse contexto, inicia-se um processo de medicalização da maternidade e do corpo feminino, baseado em estereótipos da "natureza feminina", com o objetivo de controlar os corpos das mulheres e garantir a reprodução da sociedade. Assim, conforme Elisabeth Meloni Vieira, o modelo de tratar a maternidade hoje mantém as mesmas bases do século passado, sendo excessivamente medicalizado, mas, contraditoriamente, sem efetivo acesso universal aos cuidados médicos nas sociedades concretas. $^{322} 323$

\footnotetext{
${ }^{319}$ ABRAMO, Laís (ed.). Questionando um mito: custos do trabalho de homens e mulheres. Brasília: OIT, 2005. p. 29-38.

${ }^{320}$ Ibid., p. 29-38.

${ }^{321}$ ROHDEN, Fabíola. Uma ciência da diferença: sexo e gênero na medicina da mulher. Rio de Janeiro: Editora FIOCRUZ, 2001. p. 29-30.

${ }^{322}$ VIEIRA, Elisabeth Meloni. A medicalização do corpo feminino. Rio de Janeiro: Editora FIOCRUZ, 2002. p. 60-68.
} 
Exemplo maior desse modo de ver a maternidade não apenas como doença, mas como prejuízo para o empregador é a constatação de que algumas empresas ainda tentam controlar a gravidez de suas empregadas. Em pleno ano de 2014, uma empresa de telemarketing foi condenada no TST por estabelecer uma escala de controle gestacional de suas empregadas, que mantinha planilhas denominadas "Programa de Gestação", que estabeleciam uma fila de preferência por meio da qual se determinavam quais trabalhadoras estariam "elegíveis" para engravidar, as quais deveriam comunicar à empresa com seis meses de antecedência. A finalidade era de conciliar as gravidezes das empregadas com as demandas de trabalho, em clara atitude de discriminação de gênero, como se o poder empregatício tivesse o direito de controlar os corpos e escolhas das mulheres. ${ }^{324}$

\footnotetext{
${ }^{323}$ A atual luta pela humanização do parto decorre, justamente, da prática médica de tratar o parto como uma doença e da medicalização dos corpos das mulheres, tirando delas não apenas o protagonismo, mas muitas vezes seu direito de escolha, como nos frequentes casos de violência obstétrica que ocorrem no Brasil. Destaca-se, neste movimento, a rede Parto do Princípio, que elaborou em 2012 o Dossiê "Violência Obstétrica: Parirás com dor" para a CPMI da Violência Contra as Mulheres. Disponível em: $<$ http://www. senado.gov.br/comissoes/documentos/SSCEPI/DOC\%20VCM\%20367.pdf >.. V Vale também a indicação do filme "O Renascimento do Parto", que revela o descompassado e alarmante aumento de cesarianas no país, em comparação com outros países, bem como denuncia práticas obstétricas consideradas ultrapassadas e violentas, mas que continuam a ser aplicadas nos sistemas de saúde (público e privado) por conveniência e desconhecimento, como é o caso da episiotomia e da manobra de Kristeller. (O Renascimento do Parto. Direção: Eduardo Chauvet. Documentário. Brasil.
} 2013).

${ }^{324}$ RECURSO DE REVISTA DA RECLAMANTE - CONTROLE GESTACIONAL - CONDUTA EMPRESARIAL ILÍCITA, DISCRIMINATÓRIA E OFENSIVA À DIGNIDADE DAS TRABALHADORAS - DANO MORAL - INDENIZAÇÃO. Foi reconhecida nos autos a existência de um "Programa Gestacional" instituído por uma das prepostas da empresa, no intuito de conciliar as gravidezes das empregadas com o atendimento das demandas de trabalho. Inclusive, há notícia de prova documental consistente em planilha elaborada pela gerência, estabelecendo uma fila de preferência para a atividade reprodutiva das trabalhadoras. A comprovação, por si só, da existência de um plano gestacional no âmbito da empresa, acarreta a conclusão de que todas as mulheres em idade reprodutiva envolvidas naquela planta empresarial foram ofendidas em sua dignidade (destacadamente na possibilidade de decidirem com autonomia a respeito de seus projetos de vida, de felicidade e do seu corpo) e em sua intimidade, resultando discriminadas em razão de sua condição feminina. A capacidade do empregador de difundir um clima de intimidação, determinando comportamento de suas empregadas a partir do estabelecimento desse plano, ou causando-lhes sofrimento pela incapacidade de atendê-lo ou mesmo pelo desejo contrário ao prescrito no plano gravídico, decorre da posição de subordinação jurídica em que os empregados se colocam no âmbito da relação de emprego, revelando um espectro de eficácia que alcança todas aquelas que trabalhavam nas mesmas condições e se enquadravam na prescrição empresarial, ainda que não tenham sido destinatárias diretas da determinação da gerente. O ordenamento jurídico, para além do estabelecimento da igualdade entre homens e mulheres no art. 5o $^{\circ}$ I, da Constituição Federal de 1988, já voltou seu olhar para a especial vulnerabilidade das mulheres no mercado de trabalho, em razão das suas responsabilidades reprodutivas, razão por que prescreveu a ilicitude de qualquer conduta voltada ao controle do estado gravídico das trabalhadoras. Nesse sentido, os arts. 373-A e 391, parágrafo único, da CLT. Saliente-se que a pretensão abstrata de estender seu poder empregatício para além das prescrições sobre a organização do trabalho, alcançando a vida, a autonomia e o corpo das trabalhadoras, revela desrespeito grave à dignidade da pessoa humana, que não se despe de sua condição de sujeito, nem da titularidade das decisões fundamentais a respeito da sua própria vida, ao contratar sua força de trabalho em favor de outrem. Está caracterizada, satisfatoriamente, a conduta ilícita e antijurídica do empregador, capaz de ofender a dignidade obreira, de forma culposa. Ao se preocupar exclusivamente com o 
Portanto, ao centrar-se nas trabalhadoras-mães como exclusivas responsáveis pela maternagem, nossa atual legislação demonstra-se deficiente, uma vez que não consegue combater a discriminação de gênero, tampouco resguardar a saúde das mulheres gestantes. Isso porque: os pais foram excluídos das responsabilidades familiares; as medidas de proteção da saúde reprodutiva acabam por limitar o acesso e permanência das mulheres no emprego e excluem os homens de seus benefícios; e as medidas de proteção baseadas na separação da trabalhadora do ambiente de trabalho, para resguardar sua saúde e cuidar de seu filho ou filhas, não garantem boas condições de trabalho no retorno ao posto. ${ }^{325}$ Somente uma mudança de paradigma no sentido de integrar a participação de homens e mulheres na reprodução social e no trabalho produtivo permitiria superar o sexismo nas normas de saúde e segurança do trabalho. Trataremos pontualmente delas em tópico adiante.

\subsubsection{Licença à gestante, licença-paternidade, salário-maternidade e a reprodução da divisão sexual do trabalho}

Do século XIX até hoje, tanto as práticas sociais quanto o Direito evoluíram, porém observa-se certa continuidade nas representações das mulheres no trabalho desde aquela época, uma vez que persiste na legislação a ideia de "natureza feminina" que determina o papel prioritário das mulheres na família, ao passo que praticamente ignora qualquer atribuição do homem no espaço privado. ${ }^{326}$ Fica patente o importante papel do Direito do Trabalho na reprodução da divisão sexual do trabalho, uma vez que concede às mulheres direitos relativos à reprodução, que não são estendidos aos homens.

\footnotetext{
atendimento de suas necessidades produtivas, constrangendo as decisões reprodutivas das trabalhadoras, a reclamada instrumentaliza a vida das suas empregadas, concebendo-as como meio para a obtenção do lucro, e não como fim em si mesmas. Constatada violação dos arts. $5^{\circ}$, V e X, da Constituição Federal; 373-A e 391, parágrafo único, da CLT; e 186 do Código Civil. Indenização por danos morais que se arbitra no valor de $\mathrm{R} \$ 50.000,00$. Recurso de revista conhecido e provido. (BRASIL. Tribunal Superior do Trabalho. $7^{\text {a }}$ Turma. TST-RR-755-28.2010.5.03.0143. Relator: Vieira de Mello Filho. Diário da Justiça Eletrônico 18.set 2014).

${ }^{325}$ ACEVEDO, Doris. Género y políticas de protección laboral: protección a la maternidad y la familia en la Ley Orgánica del Trabajo de Venezuela. Salud de los Trabajadores, Maracay, v.12, n.1, p. 33-53, 2004. p. 33.

${ }^{326}$ DHOQUOIS, Régine. O direito do trabalho e o corpo da mulher (França: séculos XIX e XX): Proteção da produtora ou da reprodutora? In: MATOS, Maria Izilda Santos de; SOIHET, Rachel (org.). Corpo feminino em debate. São Paulo: Editora UNESP, 2003. p. 43-56. p. 54.
} 
Nesse sentido, destaca-se o discrepante tratamento legislativo dispensado às trabalhadoras-mães em relação aos trabalhadores-pais, que fica evidente quando consideramos as licenças concedidas a cada um pelo nascimento de filho ou filha: licença à gestante de 120 dias, prevista no inciso XVIII da CF, em oposição à licençapaternidade de cinco dias, conforme inciso XIX da $\mathrm{CF}$, regulado pelo artigo $10, \S 1^{\circ}$ do ADCT.

Dentre os diversos apontamentos necessários a essa comparação, o primeiro diz respeito à clara diferenciação feita pela $C F$ entre mães e pais que trabalham. Apesar de o artigo 226, $\S 5^{\circ}$ atribuir a homens e mulheres responsabilidades iguais com relação à família, dispondo que "os direitos e deveres referentes à sociedade conjugal são exercidos igualmente pelo homem e pela mulher", a licença-paternidade é reduzida a ponto de não permitir aos pais dedicarem-se ao cuidado das crianças recémnascidas. Ademais, como constatado por Patrícia Tuma Martins Bertolin e Fabiana Larissa Kamada,

(...) a Constituição de 1988 determinou que a diferença de gênero não pode ser fonte de desigualdade (igualdade jurídica entre diferentes) e, na mesma linha, reconheceu a necessidade de proteger o mercado de trabalho da mulher, ampliou a licença-maternidade e criou a licençapaternidade. No entanto, maternidade e paternidade constaram no texto constitucional como diferentes, o que perpetua a oposição entre maternidade especificamente e o trabalho assalariado. ${ }^{327}$

Observa-se que a normativa constitucional é moldada pela ideologia que coloca os pais, homens, como provedores do sustento da família (nuclear heterossexual), ${ }^{328}$ motivo pelo qual, respeitando a divisão sexual do trabalho, as mulheres teriam direito a 120 dias de licença para poderem exercer seu papel tradicional de mãe e cuidar da criança pequena, enquanto os homens deveriam zelar pelo bem-estar da mãe e do bebê nos primeiros e mais delicados dias pós-parto, mas retornar ao trabalho logo em seguida, cumprindo seu papel de arrimo familiar.

A justificativa geralmente utilizada para a concessão de períodos de licença tão distintos para trabalhadores e trabalhadoras é a necessidade de recuperação do fragilizado organismo da mulher puérpera. Não discordamos disso. Entretanto, a

\footnotetext{
327 BERTOLIN, Patrícia Tuma Martins. KAMADA, Fabiana Larissa. Ausentes ou invisíveis? A participação das mulheres nos sindicatos. Caderno Espaço Feminino. Uberlândia, v.25, n.1, p. 28-52, jan/jun 2012. p. 37.

${ }^{328}$ MATTAR, Laura Davis. Direitos maternos: uma perspectiva possível dos direitos humanos para o suporte social à maternidade. Tese (Doutorado). Faculdade de Saúde Pública da Universidade de São Paulo. Orientadora Carmen Simone Grilo Diniz. São Paulo, 2001. p. 92.
} 
licença-maternidade para estes fins justifica-se até determinado limite, pois passado o período de recuperação pós-parto, a licença torna-se uma "licença cuidado" ou "licença educação" voltada à criança, de modo que nem mesmo o uso do termo "maternidade" ou "gestante" é compatível com o direito oferecido, uma vez que poderia ser exercido por qualquer membro da família, inclusive pelo pai.

A este respeito, a Convenção 183 da OIT, ${ }^{329}$ de proteção à maternidade, prevê, em seu artigo $4^{\circ}$, que a licença-maternidade seja concedida por no mínimo 14 semanas, sendo que, para fins de proteção da saúde das mulheres, as licenças devem incluir um período obrigatório de seis semanas logo após o parto. Entende-se que este é o período de recuperação do organismo feminino, sendo que o restante, voltado ao cuidado da criança, pode ser gozado de maneiras alternativas ou, até mesmo, pelo companheiro (ou companheira).

Da mesma forma, a justificativa de que o período de licença concedido às mães é destinado ao aleitamento materno não pode ser utilizado, uma vez que a amamentação é uma escolha das mulheres, sobre a qual o Direito não deve interferir, até porque, se não há dúvidas de que o leite materno é o ideal para o bebê no início da vida, tampouco há dúvidas sobre a atual qualidade das fórmulas usadas para sua substituição. Além disso, conforme será dito no tópico pertinente ao tema, devem ser previstas alternativas para que as mulheres possam amamentar seus filhos e filhas mesmo durante o trabalho, uma vez que garantir o aleitamento somente durante o período de afastamento do trabalho também é uma distorção.

Ainda em termos comparativos, é interessante notar que, prevista na $\mathrm{CF}$ nos mesmos moldes que a licença à gestante, a licença-paternidade deveria também ser remunerada como benefício previdenciário. No entanto, tal como tantos outros direitos constitucionais, ela ainda não foi regulamentada. A falta de interesse político para regular a matéria faz com que, 26 anos depois, ainda nos utilizemos da previsão do ADCT, que conforme seu próprio título, deveria ser provisória. Assim, ao invés de ter um padrão semelhante ao da licença-maternidade, a licença-paternidade funciona juridicamente como um prolongamento da "falta justificada por nascimento do filho", prevista no art.573, III da CLT, e, consequentemente, os cinco dias de ausência do pai são arcados pelo empregador.

\footnotetext{
${ }^{329}$ Adotada pela OIT em 2001; não ratificada pelo Brasil.
} 
Curioso atestar que a lógica de concessão da licença para cuidado de filhos e filhas exclusivamente à mãe foi reproduzida pela Lei $\mathrm{n}^{\circ} .11 .770$, de 2008, que instituiu o Programa Empresa Cidadã e possibilitou a criação da licença-maternidade de 180 dias. Além da série de exigências previstas pelo legislador para concessão da licença ampliada, é importante frisar, nas palavras de Homero Batista Mateus da Silva, que mais uma vez

(...) o empregado do sexo masculino deixou de ser contemplado, não cogitando o legislador de alguma forma de compartilhamento de licença entre a mãe e o pai, como aparece em modelos adotados em alguns países europeus. Dado que o afeto e os cuidados essenciais com o bebê podem e devem ser proporcionados tanto pela figura materna quanto pela figura paterna, não seria irrazoável propor-se um modelo de licença-maternidade obrigatoriamente pela mãe durante os meses mais críticos do recém-nascido, em que se inclui forte carga nutricional do aleitamento, e uma licença compartilhada nos meses subsequentes, em que se destacam outros aspectos como o sono, o sossego, a segurança e o desenvolvimento das habilidades perceptivomotoras da criança.

Inserido na mesma lógica, o salário-maternidade, regulado pelo artigo 71 da Lei $\mathrm{n}^{\circ}$. 8.213, de 1991 era pago exclusivamente às mulheres seguradas da previdência social. Foram os processos judiciais e a gradual aceitação por parte do INSS que inicialmente permitiram que os pais, em casos específicos, pudessem gozar desse benefício. Diante da defasagem legislativa, como mencionamos no capítulo 2, foi promulgada a Lei 12.873 , de 24 de outubro de 2013, que alterou tanto a CLT, quanto a Lei de Benefícios da Previdência Social, passando a garantir aos pais o direito ao salário-maternidade nas seguintes situações: em caso de adoção ou guarda de criança por casal, a segurada ou o segurado tem o direito de optar por receber saláriomaternidade; e em caso de falecimento da mãe que recebia salário-maternidade, biológica ou adotante, passando o pai a receber o benefício pelo tempo restante. ${ }^{331}$

Portanto, o modo como a licença à gestante, a licença-paternidade e o salário-maternidade são tratados hoje pela legislação não deixam alternativa aos casais

\footnotetext{
${ }^{330}$ SILVA, Homero Batista Mateus da. Direito do Trabalho Aplicado, vol. 3: Segurança e medicina do trabalho, trabalho da mulher e do menor. Rio de Janeiro: Elsevier, 2009. p. 180.

${ }^{331}$ Aproveitamos o tema para ressaltar que o salário-maternidade se restringe às beneficiárias do INSS, o que significa que um número expressivo de mulheres que trabalham na informalidade ou em postos precarizados ficam desamparadas na gravidez e no período pós-gestacional. Segundo a OIT, um número crescente de países "are providing maternity cash benefits to low-income residents or informal workers through non-contributory maternity cash benefits financed by public funds", iniciativa que entendemos ser necessária também no Brasil, se o intuito é a diminuição da desigualdade de gênero no país. (ADDATI, Laura; CASSIRER, Naomi; GILCHRIST, Katherine. Maternity and paternity at work: law and practice across the world. Genebra: OIT, 2014. p. 7).
} 
senão o cuidado exclusivo da mãe nos primeiros meses da criança. Nota-se que a normativa trabalhista, ainda marcada pelo sexismo, não incorporou a ideia de que maternidade e paternidade são vivências de homens e mulheres iguais, "que compõem uma humanidade que nem é masculina nem é neutra, mas sexuada, e que por isso mesmo implica vivências sexuadas". 332

Muitas vezes, como observado por Jacqueline Heinen, o Estado preservou, "quando não acentuou, as desigualdades de sexo, por meio de sua intervenção ou sua não intervenção em medidas discriminatórias relativas às mulheres". ${ }^{333}$ Este é o caso do Direito do Trabalho brasileiro, que, essencialmente maternalista, no sentido de que trata as mulheres como mães em potencial ao longo de toda sua vida ativa, é pouco efetivo em seu objetivo de proteção das trabalhadoras que também são mães, de modo que a discriminação das mulheres pelo seu potencial fértil continua uma realidade.

\subsection{Proteção específica às trabalhadoras-mães}

Nosso entendimento de que a maternidade é uma construção social e que sua noção precisa ser incorporada pela legislação - para que não reproduza os estereótipos de gênero -, não exclui a necessidade de levarmos em consideração as características verdadeiramente biológicas dos corpos de mulheres e homens, referentes à reprodução, que fazem admitir o tratamento distinto das mulheres gestantes, puérperas e lactantes.

Desde o princípio, porém, é preciso que deixemos claro que toda a exceção relativa à diferenciação legal dos sexos deve ser cautelosa. Deve-se tomar “todo o cuidado ao subtrair da 'natureza' a justificação para postulados jurídicos, principalmente porque o ser humano é uma mistura indissociável de biologia e cultura". Não podemos esquecer que a inferiorização das mulheres sempre teve apoio nas

\footnotetext{
${ }^{332}$ SOUZA-LOBO, Elizabeth. A classe operária tem dois sexos: trabalho, dominação e resistência. 2 ed. São Paulo: Editora Fundação Perseu Abramo, 2011. p. 284.

${ }^{333}$ HEINEN, Jacqueline. Políticas sociais e familiares. In: HIRATA, Helena; LABORIE, Françoise; LE DOARÉ, Hélène; SENOTIER, Danièle (org.). Dicionário Crítico do Feminismo. São Paulo: Editora Unesp, 2009. p. 188-193.
} 
instituições, que por diversas vezes reproduzem ou diluem o sexismo em discursos pretensamente científicos. ${ }^{334}$

Assim, partimos da compreensão de que o meio ambiente de trabalho precisa ser saudável e seguro para toda a força de trabalho, tanto mulheres quanto homens, em todas as fases de suas vidas. Por conseguinte, normas específicas voltadas às mulheres grávidas e lactantes são necessárias, mas as medidas de proteção devem ser estritamente referentes à gestação ou aleitamento, nunca baseadas em papéis sociais ou em modelos ideais de maternidade. ${ }^{335}$

O reconhecimento internacional do direito à proteção específica da saúde e segurança das trabalhadoras gestantes e lactantes deu-se pela primeira vez na Convenção 183 da OIT, ${ }^{336}$ sobre proteção à maternidade, cujo artigo $3^{\circ}$ determina que todos os países membros adotem

(...) las medidas necesarias para garantizar que no se obligue a las mujeres embarazadas o lactantes a desempeñar un trabajo que haya sido determinado por la autoridad competente como perjudicial para su salud o la de su hijo, o respecto del cual se haya establecido mediante evaluación que conlleva un riesgo significativo para la salud de la madre o del hijo. ${ }^{337}$

Diante da importância da questão, nos itens a seguir pretendemos analisar a normativa trabalhista brasileira estritamente em relação à garantia de saúde e segurança das trabalhadoras gestantes e lactantes, abordando ainda a necessidade de proteção à saúde reprodutiva dos homens trabalhadores, uma vez que alguns riscos podem levar à redução da fertilidade e afetar a habilidade de gerar descendentes saudáveis de ambos os sexos. ${ }^{338}$

\footnotetext{
${ }^{334}$ LOPES, Cristiane Maria Sbalqueiro. Direito do trabalho da mulher: da proteção à promoção. Cadernos Pagu, Campinas, n. 26, p. 405-430, 2006. p. 420.

${ }^{335}$ ADDATI, Laura; CASSIRER, Naomi; GILCHRIST, Katherine. Maternity and paternity at work: law and practice across the world. Genebra: OIT, 2014. p. 89.

${ }^{336}$ Adotada pela OIT em 2000; não ratificada pelo Brasil.

337 ORGANIZAÇÃO INTERNACIONAL DO TRABALHO. Convention 183 - Maternity Protection Convention. Genebra: OIT, 2000. Disponível em: <http://www.ilo.org/dyn/normlex/ en/f?p=1000:12100:0::NO::P12100_INSTRUMENT_ID,P12100_LANG_CODE:312328,es:NO>.

Acesso em: 15.ago.2014.

${ }^{338}$ ADDATI, Laura; CASSIRER, Naomi; GILCHRIST, Katherine, op. cit., p. 90.
} 


\subsubsection{A proteção das gestantes}

O Direito do Trabalho no Brasil prescreve algumas medidas de proteção específica da saúde e segurança das trabalhadoras gestantes, tanto na CLT quanto em algumas NR, que analisaremos nos parágrafos seguintes. São elas, especificamente: a dispensa do horário de trabalho para consultas e exames pré-natais; a prorrogação dos períodos de repouso, antes ou depois de parto, em até duas semanas; a transferência de função, quando as condições de trabalho apresentarem riscos à gestação; e a proibição do trabalho da gestante em contato com determinados agente químicos.

No caso das medidas protetivas da CLT, elas se concentram no artigo 392. Comecemos pelo seu $\S 2^{\circ}$, que prevê “os períodos de repouso, antes e depois do parto, poderão ser aumentados de 2 (duas) semanas cada um, mediante atestado médico", direcionado a casos excepcionais em que exista risco para a vida da mãe, do feto ou do recém-nascido. Os períodos de prorrogação da licença-maternidade, do mesmo modo que os 120 dias ordinários de licença, vêm devidamente acompanhados do pagamento de salário-maternidade para as seguradas empregadas, nos termos do artigo 93, $3^{\circ}$, do Decreto $n^{\circ}$. 3.048, de 1999.

Outro direito garantido pelo artigo 392, diz respeito ao acompanhamento pré-natal, ${ }^{339}$ essencial para a saúde das gestantes e dos bebês em desenvolvimento. Para que isso seja acessível às mulheres que estão no mercado de trabalho, o $\S 4^{\circ}$, inciso II, do referido artigo, concede às trabalhadoras o direito à "dispensa do horário de trabalho pelo tempo necessário para a realização de, no mínimo, seis consultas médicas e demais exames complementares", sem prejuízo do salário. O fato de a legislação trabalhista ter reconhecido a importância de se conceder tempo fora do trabalho para o cuidado prénatal é bastante positivo, valendo ressaltar que, segundo publicação da OIT, de 156 países sobre os quais se têm dados a esse respeito, 116 não possuem qualquer previsão nesse sentido. $^{340}$

Também no $\$ 4^{\circ}$, inciso $\mathrm{I}$, do artigo 392 da CLT, garante-se às empregadas gestantes a "transferência de função, quando as condições de saúde o exigirem, assegurada a retomada da função anteriormente exercida, logo após o retorno

\footnotetext{
${ }^{339}$ A Lei n. 9.263, de 12 de janeiro de 1996, obriga o Sistema Único de Saúde a garantir a todas as mulheres o atendimento pré-natal, nos termos do inciso II de seu artigo $3^{\circ}$.

${ }^{340}$ ADDATI, Laura; CASSIRER, Naomi; GILCHRIST, Katherine. Maternity and paternity at work: law and practice across the world. Genebra: OIT, 2014. p. 92.
} 
ao trabalho". Segundo Homero Batista Mateus da Silva, esta transferência é multifacetada,

(...) abrangendo desde os cenários mais óbvios, como a retirada da gestante dos ambientes insalubres, perigosos ou penosos, como os casos mais sutis, como a colocação de assentos no local de trabalho para a gestante poder alterar a posição incômoda, a retirada da gestante de trabalhos externos que envolvam muitos deslocamentos ou a mudança de filial para redução de tempo gasto no transporte coletivo - tudo sem prejuízo da média remuneratória, claro está. ${ }^{341}$

Cabe ressaltar que este direito se estende aos casos em que a necessidade de transferência ocorra após o retorno da empregada ao trabalho, por conta possível fragilidade no organismo ou por conta do aleitamento, bem como que a trabalhadora seja afastada do trabalho até que cessem os riscos, sem prejuízo de sua remuneração, caso a empresa não tenha local onde a empregada possa ser realocada, seja por limitação de espaço, seja porque todas as funções apresentariam risco à gestante.

Entretanto, é preciso ressalvar que as referidas garantias praticamente não são aplicadas, uma vez que, como esse afastamento não é regulado pela legislação, ele recai sobre o empregador, que deve manter o pagamento da empregada afastada. Faz-se, assim, necessária a regulamentação desse afastamento como forma suspensão do contrato de trabalho, devendo o período ser arcado pelo INSS, em molde similar ao auxílio-doença acidentário, já que se trata de período em que a mulher está incapacitada de prestar serviços por motivos médicos. ${ }^{342}$ Essa é a única forma que vislumbramos para garantir o cumprimento efetivo do afastamento e, consequentemente, para proteger a saúde tanto das trabalhadoras quanto dos embriões expostos aos riscos ambientais.

Nesse sentido, a legislação espanhola é exemplo a ser seguido: desde a edição da Lei Orgânica $\mathrm{n}^{\circ}$. 3, de 2007, "para la igualdad efectiva de mujeres y hombres", afastamento por riscos à gravidez e ao feto passou a ser tratado como um afastamento por doença ou acidente do trabalho, o que faz com que o contrato de

\footnotetext{
${ }^{341}$ SILVA, Homero Batista Mateus da. Direito do Trabalho Aplicado, vol. 3: Segurança e medicina do trabalho, trabalho da mulher e do menor. Rio de Janeiro: Elsevier, 2009. p. 169.

${ }^{342}$ A abordagem da temática da suspensão do contrato de trabalho para garantia da saúde e segurança das mulheres faz lembrar a suspensão prevista na Lei Maria da Penha (Lei nº 11,340, de 2006), cuja intenção é interpretada no sentido de garantir que o afastamento do trabalho da mulher em situação de violência não possa ser considerado abandono de emprego. Desse modo, o juiz emite notificação para que o empregador suspenda o contrato, o que consequentemente suspende a remuneração. Entretanto, apesar dessa medida permitir que a mulher requeira benefícios assistenciais enquanto estiver sob proteção do Estado, entendemos que o ideal seria a garantia previdenciária de manutenção de seu salário, ou ao menos de uma fração dele, a fim de evitar o agravamento da situação de grande vulnerabilidade da trabalhadora.
} 
trabalho seja suspenso e a trabalhadora passe a receber benefício do instituto de seguridade social espanhol. ${ }^{343}$

Apesar das medidas do artigo 392 da CLT prescreverem medidas importantes para a preservação da saúde das gestantes e do embrião em desenvolvimento, elas não são suficientes. Isso porque, durante a gravidez, os corpos das mulheres passam por mudanças que podem agravar os efeitos da exposição a determinados riscos, tornando-as mais sensíveis a doenças e acidentes de trabalho. Ademais, a exposição das trabalhadoras gestantes a certas condições labor-ambientais pode também interferir no desenvolvimento do futuro bebê. ${ }^{344}$

No caso do embrião em formação, algumas substâncias podem atravessar a barreira placentária, motivo pelo qual as concentrações de agentes nocivos à saúde normalmente permitidas no ambiente de trabalho, nem sempre são seguras para o produto da concepção. ${ }^{345}$ As exposições ocupacionais, seja pela contaminação do ar ou pela manipulação de substâncias específicas, podem afetar o desenvolvimento do embrião e o curso da gestação. "Podem determinar mutagênese, abortamento, natimortalidade, prematuridade, teratogênese, carcinogênese etc.". 346

No Brasil, somente as NR 31, NR 32, e a Norma CNEN-NE-3.01, a que o Anexo 5 da NR 15 faz menção, possuem regras específicas a respeito da exposição das gestantes a determinados riscos ocupacionais. A primeira veda "a manipulação de quaisquer agrotóxicos, adjuvantes e produtos afins por menores de dezoito anos, maiores de sessenta anos e por gestantes" (item 31.8.3). A segunda condiciona o trabalho das gestantes em ambientes com possibilidade de exposição a gases ou vapores anestésicos à autorização (item 32.3.9.3.4) e impõe ao empregador o dever de afastar as gestantes e nutrizes de atividades com quimioterápicos antineoplásicos (item 32.3.9.4.6). Já a terceira traz limite de tolerância reduzido para a exposição de mulheres grávidas a radiações ionizantes.

\footnotetext{
${ }^{343}$ AGUILERA IZQUIERDO, Raquel. Los derechos de conciliación de la vida personal, familiar y laboral en la Ley Orgánica para la igualdad efectiva de mujeres y hombres. Revista Del Ministerio De Trabajo y Asuntos Sociales, Madrid, n. extra 2, p. 69-119, 2007. p. 75-76.

${ }^{344}$ PÉREZ CAMPOS, Ana Isabel. Salud laboral y trabajo femenino: mecanismos de protección y prevención. Anuario Jurídico y Económico Escurialense, La Rioja, n.40, p. 195-228, 2007. p. 198-199.

345 TUDOR, Talitha do Carmo. Trabalho da mulher - estágio atual. Revista Brasileira de Saúde Ocupacional, Ministério do Trabalho / Fundacentro, v. 38, n. 10, abr/mai/jun.1982. p. $43-47$.

${ }^{346}$ HOFMEISTER, Vera Anna. Estudo do término de gestações de trabalhadoras em indústrias. Revista Brasileira de Saúde Ocupacional, Ministério do Trabalho / Fundacentro, v. 38, n.10, abr/mai/jun.1982. p. $38-42$.
} 
No entanto, essa regulamentação não contempla muitos dos riscos ocupacionais que podem interferir na gravidez e no desenvolvimento do feto, cujos limites de exposição diferem dos comumente mensurados. Trataremos aqui de alguns exemplos de riscos específicos aos quais as gestantes não poderiam ser expostas, mas que não foram contemplados pela normativa brasileira.

O primeiro exemplo a ser citado são os esforços físicos prolongados e a exposição a vibrações. A OIT recomenda a proibição do emprego de mulheres grávidas em "qualquer trabalho pesado que implique levantar, puxar ou empurrar pesos, ou exija esforços físicos, incluindo permanecer de pé durante períodos de tempo prolongados", bem como em "trabalho que exija especial equilíbrio" e no "trabalho com máquinas vibradoras". ${ }^{347}$ No tocante às vibrações, estudo divulgado pela Fundacentro demonstrou que as vibrações de baixa frequência e grande amplitude produzem um "relaxamento do sistema de suporte do útero, e determinam um deslizamento desse órgão nas gestantes", ${ }^{348}$ porém o Anexo 8 da NR 15 não faz nenhuma menção à proteção específica das gestantes.

Também merece ser citado como exemplo o ruído ocupacional, que embora pareça interferir apenas no sistema auditivo da gestante, pode gerar reflexos no embrião em desenvolvimento. Segundo Giovana Verri Palma Dias, "a mesma exposição ao ruído que pode causar perda temporária de audição para adultos pode causar danos permanentes em um sistema auditivo em desenvolvimento", pois o feto, cujo desenvolvimento da audição se inicia por volta do quarto mês de gestação, possivelmente não estará preparado para os estímulos sonoros do corpo da mãe. ${ }^{349}$

O guia da ACGIH faz menção ao ruído ocupacional para o feto, abordando evidências de que a exposição da barriga da mãe a ruído contínuo a partir de $115 \mathrm{~dB}$, ou a ruídos com picos superiores a $155 \mathrm{~dB}$, pode causar perda auditiva no futuro bebê depois do quinto mês de gestação. ${ }^{350} \mathrm{Em}$ contrapartida, nem o Anexo 1,

\footnotetext{
347 ORGANIZAÇÃO INTERNACIONAL DO TRABALHO. O ABC dos direitos das mulheres trabalhadoras e da igualdade de género. 2 ed. Genebra: OIT, 2007. p. 172.

348 COLLEONI, Nelson; CIANCI FILHO, José; ZANETTI, Noemi; KARAGUELIAN, Suely; GIANNETTI, Marcia. O trabalho profissional da gestante e a proteção materno-infantil. Revista Brasileira de Saúde Ocupacional, Ministério do Trabalho / Fundacentro, v. 38, n.10, abr/mai/jun.1982. p. 58-62.

${ }^{349}$ DIAS, Giovana Verri Palma. A gestante exposta ao ruído. In: INSTITUTO LATINOAMERICANO DE EDUCAÇÃO INTEGRAL. Um olhar de gênero na saúde e segurança no trabalho, ILEI, São Paulo, nov.2005. p. 32-33.

${ }^{350}$ ACGIH. 2011: TVLs \& BEIs. Tradução: Associação Brasileira de Higienistas Ocupacionais. São Paulo: ABHO, 2011. p. 129.
} 
nem o Anexo 2 da NR 15 tratam da questão. A ausência de limites específicos às gestantes para a exposição ao agente ruído em nossa legislação permite a aplicação dos valores determinados pela ACGIH, nos termos do já mencionado item 9.3.5.1 da NR 9.

Além das ausências verificadas na normativa brasileira em relação à imposição de limites de exposição específicos para gestantes, observa-se também que, na busca por evitar potenciais danos sobre a gestação e o desenvolvimento embrionário, muitas vezes o Direito do Trabalho deixou de lado os riscos à saúde reprodutiva dos homens. Desse modo, algumas medidas protetivas tradicionalmente direcionadas às mulheres acabam por desproteger os homens.

Pesquisas têm demonstrado a relação de diversos riscos e condições de trabalho com problemas na reprodução biológica de ambos os sexos: “(...) la exposición laboral a sustancias químicas, radiaciones, temperaturas extremas y estrés ha estado asociada a trastornos de la fertilidad de hombres y mujeres trabajadoras, a abortos, daños cromosómicos, malformaciones congénitas". ${ }^{351}$ Desse modo, interessante frisar que a exposição paterna pode afetar não apenas a capacidade de concepção, mas também o concepto, pois existem agentes capazes de gerar danos ao DNA do espermatozóide e mutações em células germinativas em processo de divisão. ${ }^{352}$

Podemos citar como exemplo a exposição de trabalhadores rurais a pesticidas, potenciais causadores de infertilidade, diminuição do número de espermatozóides e malformação do embrião fecundado por espermatozóide exposto à toxidade. ${ }^{353}$ Também a exposição de homens trabalhadores a radiações ionizantes, que possuem efeitos mutagênicos e teratogênicos, podem provocar "sterility and mutagenic effects". 354

Em relação às substancias químicas, Margarida Barreto elencou os possíveis efeitos dessa exposição sobre trabalhadores e trabalhadoras. Nas mulheres, pode ocasionar transtornos do sistema endócrino e do sistema nervoso central, gerando

\footnotetext{
${ }^{351}$ ACEVEDO, Doris. Género y políticas de protección laboral: protección a la maternidad y la familia en la Ley Orgánica del Trabajo de Venezuela. Salud de los Trabajadores, Maracay, v.12, n.1, p. 33-53, 2004. p. 35.

${ }^{352}$ PAUMGARTTEN, Francisco J.R. Doenças da Reprodução e malformações congênitas relacionadas com o trabalho. In: MENDES, René (org.). Patologia do Trabalho. $3^{\mathrm{a}}$ ed. São Paulo: Atheneu, 2013. p. 1479-1504. p. 1485-1486.

${ }^{353}$ BARRETO, Margarida. O trabalho engendrando doenças e diferenças. In: BARRETO, Margarida; CARLOTO, Cássia Maria; COSTA, Maria Luiza da. Saúde das Trabalhadoras. São Paulo: SOF Sempreviva Organização Feminista, 1998. p. 59-79. p. 70.

${ }^{354}$ FORASTIERI, Valentina. Women workers and gender issues on occupational safety and health: Information Note. Genebra: OIT, 2010. p. 6.
} 
diminuição da fertilidade, alteração menstrual e diminuição da libido; danos às células germinativas nos cromossomos, com a possibilidade de morte fetal, malformação congênita e câncer infantil; disfunção e morte de células fetais; e alterações no leite materno, levando consequentes enfermidades ao recém-nascido. Nos homens, a exposição pode gerar transtornos ao sistema endócrino, com diminuição da fertilidade; transtornos no sistema nervoso central, com diminuição da libido; atrofia testicular, o que pode ocasionar diminuição da fertilidade e alterações nas propriedades do esperma; agravos nas células germinativas e cromossomos, que podem ocasionar morte fetal e malformação congênita; inserir toxinas no líquido seminal, causando a imobilidade do espermatozóide. $^{355}$

Diante desse quadro, fica claro o tratamento sexista da legislação e a necessidade de que as normas de proteção à saúde reprodutiva das mulheres trabalhadoras sejam estendidas aos homens trabalhadores, uma vez que sua capacidade reprodutiva e, até mesmo a formação de seus filhos ou filhas, podem ser afetadas por exposições a agentes nocivos no ambiente de trabalho. Ironicamente, enquanto essas normas extrapolam na proteção e acabam por discriminar, a legislação deixa de estipular proteções necessárias às gestantes, lacunas danosas à saúde gestacional e embrionária. Fica evidente a necessidade de adequações em nosso ordenamento.

\subsubsection{A proteção das lactantes}

A valorização do aleitamento materno, observada nos incentivos sociais e estatais e na ampla divulgação de seus benefícios tanto para as mães quanto para as crianças, não se reflete no Direito do Trabalho, que não garante satisfatoriamente o direito das mulheres trabalhadoras amamentarem seus descendentes, tampouco se preocupa com a saúde da lactante, do bebê alimentado ou com a qualidade do leite materno produzido no ambiente de trabalho.

A lactância, enquanto atividade de alimentação de filhos ou filhas, pode ser natural, artificial ou mista, mas em qualquer dos casos implica um estreito e repetido contato com a criança, do que decorre que se a lactante estiver exposta em seu trabalho

\footnotetext{
355 BARRETO, Margarida. O trabalho engendrando doenças e diferenças. In: BARRETO, Margarida; CARLOTO, Cássia Maria; COSTA, Maria Luiza da. Saúde das Trabalhadoras. São Paulo: SOF Sempreviva Organização Feminista, 1998. p. 59-79. p. 68-69.
} 
a agentes nocivos à saúde, eles podem ser transmitidos ao recém-nascido ou recémnascida, sejam pelo leite materno, seja por outras vias como a cutânea ou respiratória. ${ }^{356}$ Especialmente em relação à qualidade do leite materno produzido, a exposição de nutrizes a substâncias químicas no local de trabalho, mesmo em períodos anteriores à lactação, pode resultar em exposição significativa também dos lactentes. Isso porque "substâncias lipofílicas a que a nutriz foi exposta (e.g. hidrocarbonetos aromáticos policíclicos, solventes, medicamentos) e estão presentes no seu sangue, tendem a se concentrar na gordura do leite", sendo transferidas por essa via para a criança. $^{357}$

No ordenamento jurídico brasileiro, entretanto, a única norma que, por extensão, pode garantir proteção contra esses efeitos é o já estudado artigo $392, \S 2^{\circ}$ da CLT, mas que expressamente fala apenas das gestantes. Desse modo, em caso de exposição a agentes que possam causar danos à sua saúde ou problemas na produção do leite, as trabalhadoras lactantes podem pleitear transferência de função, assegurada a retomada da função exercida depois de findado o risco.

Além da proteção à saúde da mãe lactante e da garantia à não contaminação do leite que alimenta o bebê, é preciso garantir condições para que a mãe de fato amamente a criança. Segundo o Ministério da Saúde e o Centro Brasileiro de Análise e Pesquisa, 95\% das mulheres brasileiras iniciam a amamentação após o parto, porém a proporção do aleitamento exclusivo do primeiro ao terceiro mês cai para $48 \%$ e baixa ainda mais entre o quarto e quinto mês, quando é de apenas $14 \% .{ }^{358}$ Acredita-se que um dos fatores para o desmame brusco no período dos 4 a 5 meses da criança seja a volta da mulher ao trabalho fora de casa, o que significa, especialmente para as trabalhadoras urbanas, maiores dificuldades para estar com o bebê e amamentar. ${ }^{359}$

Nesse sentido, estão prescritos na CLT como direitos das trabalhadoras: dois intervalos especiais durante a jornada de trabalho, de meia hora cada, para

\footnotetext{
${ }^{356}$ PÉREZ CAMPOS, Ana Isabel. Salud laboral y trabajo femenino: mecanismos de protección y prevención. Anuario Jurídico y Económico Escurialense, La Rioja, n.40, p. 195-228, 2007. p. 199.

${ }^{357}$ PAUMGARTTEN, Francisco J.R. Doenças da Reprodução e malformações congênitas relacionadas com o trabalho. In: MENDES, René (org.). Patologia do Trabalho. $3^{\mathrm{a}}$ ed. São Paulo: Atheneu, 2013. p. 1479-1504. p. 1486.

${ }^{358}$ BRASIL; CENTRO BRASILEIRO DE ANÁLISE E PESQUISA. Pesquisa Nacional de Demografia e Saúde da Criança e da Mulher: PNDS 2006. Brasília: Ministério da Saúde, 2006. p. 201-204.

${ }^{359}$ REA, Marina Ferreira; VENÂNCIO, Sonia Isoyama; BAISTA, Luis Eduardo; SANTOS, Rosangela Gomes dos; GREINER, Ted. Possibilidades e limitações da amamentação entre mulheres trabalhadoras formais. Revista de Saúde Pública, São Paulo, n. 2, v. 31, p. 402-416, abril/1997. p. 150.
} 
amamentação da criança até que complete seis meses, conforme artigo 396; e local apropriado para guarda de filhos e filhas das empregadas durante o período da amamentação, consoante artigo $389, \S 1^{\circ}$ e $\operatorname{artigo} 400$.

No que se refere ao artigo 396, observa-se que a previsão do direito aos intervalos para a amamentação limita, ainda que indiretamente, o aleitamento das crianças filhas de trabalhadoras até seis meses, o que conduz à diminuição da frequência da lactância natural, quando não sua completa cessação. Única alternativa, concedida nos casos em que a saúde da criança exigir, é a dilação prevista no parágrafo único, que ficou a critério da autoridade competente, ou seja, o médico.

Os períodos de descanso para amamentação, expressamente reconhecidos como "especiais", não podem ser descontados da jornada da empregada, sendo uma pausa remunerada, despesa que recai sobre o empregador. Desse modo, conforme afirma Homero Batista Mateus da Silva, o período de amamentação não é comparável ao intervalo para refeição do artigo $71 .^{360}$ Quanto aos abusos praticados pelos empregadores para "reduzirem os impactos produtivos" supostamente causados pela concessão deste direito, o autor explica que não está correto

(...) somar duas pausas de meia hora e conceder uma saída de uma hora mais cedo para a empregada ou uma folga por semana pelas pausas desvirtuadas. Tudo isso causa perplexidade. Maior ainda será o espanto quando o direito do trabalho encontrar a empresa que paga horas extras pela violação à pausa de amamentação. Poderíamos chamar essa pausa de especial e urgente, pois não há meio algum de substituição ao alcance dessa norma. Se acaso a lactante demonstrar em processo do trabalho ter sido impedida de amamentar, seria o caso de uma pesada indenização pecuniária e não de se discutirem horas extras, ou multa da Delegacia Regional do Trabalho. Afinal, nem mesmo a indenização pecuniária suprirá a carência nutricional. ${ }^{361}$

Nesse sentido, necessário frisar que, além das tentativas de burla, a efetividade da norma fica comprometida devido à ausência de lugares para guarda das crianças, tanto dentro quanto próximos aos locais de trabalho, o que inviabiliza, especialmente em grandes centros urbanos, que as trabalhadoras gozem do direito aos

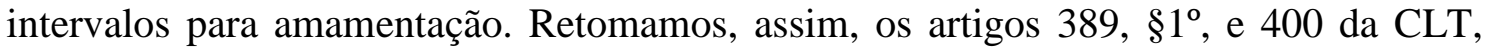
que preveem como dever das empresas, com mais de 30 empregadas, o fornecimento de

\footnotetext{
${ }^{360}$ SILVA, Homero Batista Mateus da. Direito do Trabalho Aplicado, vol. 3: Segurança e medicina do trabalho, trabalho da mulher e do menor. Rio de Janeiro: Elsevier, 2009. p. 182.

${ }^{361}$ Ibid., p. 182.
} 
creches no local de trabalho às crianças filhas de trabalhadoras durante o período de amamentação.

Nas palavras de Cristiane Maria Sbalqueiro Lopes, "não causará surpresa a ninguém o fato de que essa norma, de uma maneira geral, simplesmente não é cumprida". ${ }^{362}$ Ademais, a previsão do $\S 2^{\circ}$ do artigo 389 , de que exigência do $\S 1^{\circ}$ poderá ser suprida por meio de creches distritais mantidas diretamente ou mediante convênios com outras entidades, praticamente extingue com a real possibilidade de que os empregadores disponham de tais locais para a guarda das crianças e, por conseguinte, inviabiliza os intervalos para amamentação, uma vez que os convênios são a solução mais confortável para as empresas. Não sendo isso o suficiente, o Ministério do Trabalho, editou a Portaria n. 3.296, em 1986, que criou "reembolso-creche", opção da empregada, referente à possibilidade de reembolso pelo empregador das despesas efetuadas com creches particulares. ${ }^{363}$

Apesar dessas alternativas, entendemos que o direito das trabalhadoras a lugares para a guarda de seus filhos e filhas dentro das empresas é insubstituível e cumpre importante papel em diversas esferas da vida dessas mulheres, inclusive interferindo em sua saúde. É o que demonstra pesquisa realizada por Maria Amélia de Almeida Teles, Maria Aparecida Medrado e Adriana Maria Carbonel Gragnani em 38 creches/berçários mantidos no local de trabalho, segundo a qual, a existência desses espaços: possibilita a conciliação entre o horário de trabalho das mães e o horário de funcionamento da creche; incentivam a amamentação e garantem condições objetivas para o cumprimento dos dois períodos diários previstos na lei; permitem a proximidade entre mãe e criança e a fiscalização do funcionamento da creche, o que reduz a ansiedade no trabalho; e "colabora para a redução de acidentes de trabalho, para a diminuição do absenteísmo e o aumento da produtividade, na medida em que propiciam maior tranquilidade para as mães trabalhadoras". 364

Por outro lado, "os convênios respondem a uma necessidade legal da empresa, mas não às necessidades da mãe trabalhadora". Segundo as autoras, as vagas dessas creches são raramente utilizadas, porque muitas vezes são distantes do local de

\footnotetext{
${ }^{362}$ LOPES, Cristiane Maria Sbalqueiro. A efetivação do direito à creche no Brasil. Revista do Ministério Público do Trabalho, Brasília, n.40, p. 38-60, set.2010. p. 53.

${ }^{363}$ Ibid., p. 52.

${ }^{364}$ TELES, Maria Amélia de Almeida; MEDRADO, Maria Aparecida e GRAGNANI, Adriana Maria Carbonell. Creches e berçários em empresas privadas paulistas. Cadernos de Pesquisa, São Paulo, n.57, p. 39-54, 1986. p. 49.
} 
trabalho, há dificuldades de transporte para as trabalhadoras levarem as crianças, o horário de funcionamento é incompatível com o turno de trabalho das mães ou, simplesmente, as trabalhadoras desconhecem o convênio e seu direito. ${ }^{365}$

Entretanto, concordamos com Alice Monteiro de Barros quando afirma que encarregar exclusivamente o empregador pelo custeio de creches, "implica aumento no custo da mão-de-obra feminina, dificultando o emprego de mulheres". ${ }^{366}$ A necessidade de berçários, creches e pré-escolas é uma necessidade da sociedade brasileira, e um direito das crianças, homens e mulheres, assegurado pela norma constitucional, não podendo ficar restrito à provisão empresarial.

Por fim, é preciso ressaltar, a despeito de a CF não limitar o direito à creche apenas às trabalhadoras, o legislador ordinário sempre restringiu às empregadas o direito à creche fornecida pelo empregador, seja ela no local de trabalho ou conveniada, o que vale, inclusive, para o reembolso-creche, que fala expressamente em “empregada-mãe". 367 Isso faz com que a determinação seja "duplamente discriminatória", por aumentar injustamente o custo da força de trabalho feminina e por excluir injustamente os pais, ferindo o direito à igualdade no trabalho. ${ }^{368}$

\subsection{Meios jurídicos para a garantia do direito ao trabalho das mulheres que decidem ter filhos ou filhas e amamentar}

O panorama traçado ao longo do capítulo faz perceber que a escolha entre trabalho e maternidade é um risco residual do trabalho feminino, uma vez que é sobre as mulheres que recai a carga do trabalho nas esferas pública e privada. Assim, apesar de as mães trabalhadoras terem uma série de direitos reconhecidos, que visam proteger tanto a saúde da mulher quanto da criança, não há controle ou garantia de que sua aplicação de fato colabore para a igualdade no trabalho.

\footnotetext{
${ }^{365}$ LOPES, Cristiane Maria Sbalqueiro. A efetivação do direito à creche no Brasil. Revista do Ministério Público do Trabalho, Brasília, n.40, p. 38-60, set.2010. p. 50.

${ }^{366}$ BARROS, Alice Monteiro de. O trabalho da mulher: revisão de conceitos. In: PENIDO, Laís de Oliveira (coord.). Igualdade dos gêneros nas relações de trabalho. Brasília: ESMPU, 2006. p. 51-82. p. 81.

${ }^{367}$ SILVA, Homero Batista Mateus da. Direito do Trabalho Aplicado, vol. 3: Segurança e medicina do trabalho, trabalho da mulher e do menor. Rio de Janeiro: Elsevier, 2009. p. 183.

${ }^{368}$ LOPES, Cristiane Maria Sbalqueiro, op. cit., p. 52.
} 
Se a necessidade de cuidado de filhos e filhas é causa de afastamento das mulheres do mercado de trabalho, é fundamental garantir que elas tenham tempo para se dedicar ao trabalho remunerado como medida de combate à discriminação. Homens e mulheres devem ter garantido o direito ao trabalho, exercido de forma que permita a compatibilização entre o direito de ter uma família e de prover seu sustento, conforme previsto no artigo 229 da CF: "Os pais têm o dever de assistir, criar e educar os filhos menores, e os filhos maiores têm o dever de ajudar e amparar os pais na velhice, carência ou enfermidade".

Considerando que as fronteiras entre trabalho e casa são mais permeáveis para mulheres que para homens, é preciso atentar ao fato de que sua saúde é moldada pela somatória de suas experiências como trabalhadoras, mães, filhas e companheiras. Por conseguinte, é necessário que busquemos soluções para viabilizar a permanência das mulheres no mercado de trabalho, possibilitando uma melhor conciliação entre a maternidade e a vida profissional. Assim, a busca por maior igualdade precisa de medidas que ultrapassem a proteção das mães trabalhadoras, sendo necessária a redefinição das responsabilidades no âmbito da família. ${ }^{369}$

A esse respeito, em âmbito internacional existe a Convenção 156, sobre trabalhadoras e trabalhadores com responsabilidades familiares, ainda não ratificada pelo Brasil. ${ }^{370}$ Os artigos $4^{\circ}$ e $5^{\circ}$ do documento tratam de medidas centrais para a efetivação da igualdade de oportunidades no trabalho e compartilhamento dos encargos familiares de homens e mulheres que compõem a força de trabalho. São eles:

Artigo $4^{\circ}$. Com vista ao estabelecimento de uma efetiva igualdade de oportunidades e de tratamento para homens e mulheres trabalhadores, serão tomadas todas as medidas compatíveis com as condições e as responsabilidades nacionais para: a) dar condições a trabalhadores com encargos de família de exercer seu direito à livre escolha de emprego e b) levar em consideração suas necessidades nos termos e condições de emprego e de seguridade social.

Artigo $5^{\circ}$. Serão tomadas ainda todas as medidas compatíveis com as possibilidades nacionais para: a) levar em consideração, no planejamento comunitário, as necessidades de trabalhadores com encargos de família e b) desenvolver ou promover serviços comunitários, públicos ou privados, como serviços e meios de assistência à infância e família. ${ }^{371}$

\footnotetext{
${ }^{369}$ SCHIRMER, Janine, Trabalho e maternidade: qual o custo para as mulheres? In: OLIVEIRA, Eleonora Menicucci de; SCAVONE, Lucila. (org). Trabalho, Saúde e Gênero na era da globalização. Goiânia: AB Editora, 1997. p. 101-113.

${ }^{370}$ Adotada pela OIT em 1981.

${ }^{371}$ ORGANIZAÇÃO INTERNACIONAL DO TRABALHO. Convenção 156, sobre a igualdade de oportunidades e de tratamento para homens e mulheres trabalhadores: trabalhadores com encargos de
} 
Nesse sentido, é necessário repensar a maneira como o Direito do Trabalho brasileiro trata as mulheres, para que ao invés de "proteger" o trabalho feminino por meio de legislações especiais, que muitas vezes reforçam os estereótipos de gênero e geram discriminação, busquem-se meios jurídicos para "despublicizar" 372 parte do trabalho masculino e medidas que permitam a socialização do trabalho doméstico feminino não remunerado. Vislumbramos, para a primeira hipótese, a licença parental, e para a segunda, a efetivação do direito a creches públicas, pelos motivos que exporemos a partir de agora.

\subsubsection{Licença parental}

Apesar de não ser atribuição do Direito, tampouco sua pretensão, estabelecer modelos para a convivência dos diversos tipos de família, o ordenamento jurídico tem capacidade, senão a obrigação, de remover o máximo de obstáculos ou dificuldades que afetem diretamente as relações familiares, para que seus integrantes tenham verdadeiramente escolhas livres na esfera privada. Assim, a legislação deve servir de base para que o compartilhamento de responsabilidades familiares seja efetivo e para que o tempo de trabalho e o tempo de atenção à família sejam melhor compatibilizados. ${ }^{373}$

O primeiro passo simbólico nessa direção é a alteração das palavras usadas para identificar as regras de proteção à reprodução biológica e social, de modo a evitar o termo "maternidade" e substituí-lo por "parentalidade", o que deixa explícito que estão contempladas as responsabilidades familiares compartilhadas entre mães e pais, não atribuindo o trabalho reprodutivo e de cuidados apenas às mulheres. ${ }^{374}$ Ademais, a expressão também permite abarcar tipos de parentalidade não

familiares. Genebra: OIT, 1981. Disponível em: <http://www.oitbrasil.org.br/content/sobre-igualdade-deoportunidades-e-de-tratamento-para-homens-e-mulheres-trabalhadores-trabal>. Acesso em: 15.ago.2014.

372 MARCONDES, Willer Baumgartem; ROTENBERG, Lúcia; PORTELA, Luciana Fernandes; MORENO, Claudia Roberta de Castro. O peso do trabalho "leve" feminino à saúde. São Paulo em Perspectiva, São Paulo, v. 17, n. 2, p. 91-101, abr./jun. 2003. p. 100.

373 AGUILERA IZQUIERDO, Raquel. Los derechos de conciliación de la vida personal, familiar y laboral en la Ley Orgánica para la igualdad efectiva de mujeres y hombres. Revista Del Ministerio De Trabajo y Asuntos Sociales, Madrid, n. extra 2, p. 69-119, 2007. p. 70.

${ }^{374}$ ACEVEDO, Doris. Género y políticas de protección laboral: protección a la maternidad y la familia en la Ley Orgánica del Trabajo de Venezuela. Salud de los Trabajadores, Maracay, v.12, n.1, p. 33-53, 2004. p. 47-49. 
heteronormativos, como nos casos das famílias monoparentais e das famílias com duas mães ou com dois pais.

O passo adiante, porém, seria alteração do modo como a legislação trata a licença-maternidade e o salário-maternidade como direitos exclusivos das mulheres, salvo poucas exceções, o que não deixa alternativa aos casais senão a dedicação das mães ao cuidado das crianças e a continuidade do trabalho produtivo dos pais, como analisado em tópico específico. Saída para a mudança desse paradigma sexista é adoção da licença parental. Isso não significa que as mulheres deixariam de ter o repouso pós-parto para restabelecimento, mas que o período posterior à recuperação do organismo feminino poderia ser gozado por qualquer das partes do casal.

$\mathrm{O}$ fato de serem as mulheres que gozam do período mais longo de licença para cuidarem das crianças recém-nascidas acaba por enfraquecer sua posição no mercado e reforçar a divisão sexual do trabalho, exacerbando as desigualdades de gênero. Desse modo, uma legislação que permita a divisão, de ao menos parte desse período com os homens, proporciona a ambos a permanência no mercado de trabalho e a possibilidade de assumirem as responsabilidades familiares de modo mais igualitário. No início, medidas como a definição de partes da licença parental como direitos individuais e intransferíveis dos pais são necessárias para garantir uma participação efetiva dos homens nesse compartilhamento. ${ }^{375}$

As atuais orientações da OIT são favoráveis à licença parental compartilhada, tendo a organização inclusive reconhecido que tratou apenas da licença-maternidade por um período, mas que mudar esse enfoque é fundamental. ${ }^{376}$ Nesse sentido, as Recomendações 165 e 191 contam com disposições sobre a licença parental, que transcrevemos:

\footnotetext{
${ }^{375}$ ADDATI, Laura; CASSIRER, Naomi; GILCHRIST, Katherine. Maternity and paternity at work: law and practice across the world. Genebra: OIT, 2014. p. 62.

376 "The Employment (Women with Family Responsibilities) Recommendation, 1965 (No. 123) and the Maternity Protection Recommendation, 1952 (No. 95), which preceded Recommendations No. 191 and No. 165 cited above, only included provisions on maternity leave and only women's need to reconcile work with family responsibilities was considered. One important change in the policy of the ILO with the adoption of the current Recommendations and the Convention on Workers with Family Responsibilities, 1981 (No. 156) was the recognition of fathers' involvement in family responsibilities in general and, in this case, with particular regard to parental leave. This was an important step towards the creation of effective equality of opportunity and treatment for men and women workers. As discussed below, the way in which fathers are included in childcare leave policies can have important implications for gender equality as well as for the level of fathers' engagement with those policies". (ADDATI, Laura; CASSIRER, Naomi; GILCHRIST, Katherine. Maternity and paternity at work: law and practice across the world. Genebra: OIT, 2014. p. 61).
} 
R. 165. Parágrafo 22.(1) Durante un período inmediatamente posterior a la licencia de maternidad, la madre o el padre deberían tener la posibilidad de obtener una licencia (licencia parental) sin perder su empleo y conservando los derechos que se derivan de él. (2) La duración del período posterior a la licencia de maternidad y la duración y las condiciones de la licencia a que se hace referencia en el subpárrafo 1) anterior deberían determinarse en cada país por uno de los medios previstos en el párrafo 3 de la presente Recomendación.(3) La licencia a que se hace referencia en el subpárrafo 1) anterior debería introducirse en forma gradual. ${ }^{377}$

R. 191. Parágrafo 10. (3). La madre que trabaja o el padre que trabaja deberían tener derecho a una licencia parental durante el período siguiente a la expiración de la licencia de maternidad. (4) El período durante el cual podría otorgarse la licencia parental, así como la duración y otras modalidades de la misma, incluidos el pago de prestaciones parentales y el goce y la distribución de la licencia parental entre los progenitores empleados, deberían determinarse en la legislación nacional o de otra manera conforme con la práctica nacional. ${ }^{378}$

De acordo com estudo da própria OIT, publicado em 2014, de 169 países no mundo com informações disponíveis sobre este direito, 66 tinham disposições sobre licença parental. A América Latina foi retratada como uma região onde as disposições sobre licença parental são mais escassas, pois apenas dois países entre os 31 dispunham sobre esse direito: Cuba, que além da licença-maternidade, concede à mãe ou ao pai o direito à licença parental até que a criança complete um ano, pagos a $60 \%$ do salário; e Chile, que concede às mães trabalhadoras licença remunerada pelo total dos rendimentos por 12 semanas, seis das quais podem ser compartilhadas com o pai, caso a mulher concorde. ${ }^{379}$

Em contrapartida, a Europa foi destacada como a região do mundo com maiores progressos do desenvolvimento da licença parental. Segundo a pesquisa,

(...) in 2010, the Council of the European Union adopted a Framework Agreement by the European social partners on parental leave (Directive 2010/18/EU, which replaced the earlier 1996 framework, 96/34/EC). The framework sets out minimum requirements for parental leave with the objectives of reconciling professional and family responsibilities and promoting equal opportunities and treatment between women and men (effective as of March 2012). In part, the revision aimed to increase take-up of

\footnotetext{
377 Disponível em: <http://www.ilo.org/dyn/normlex/en/f?p=1000:12100:0::NO::P12100_ INSTRUMENT_ID,P12100_LANG_CODE:312503,es:NO>. Acesso em: 15.ago.2014.

378 Disponível em: <http://www.ilo.org/dyn/normlex/en/f?p=1000:12100:0::NO::P12100 INSTRUMENT_ID,P12100_LANG_CODE:312529,es:NO>. Acesso em: 15.ago.2014.

${ }^{379}$ ADDATI, Laura; CASSIRER, Naomi; GILCHRIST, Katherine. Maternity and paternity at work: law and practice across the world. Genebra: OIT, 2014. p. 64.
} 
parental leave by fathers; it increased leave by one month to a total of four months for each parent and strengthened leave as an individual right by making one month for each parent non-transferable. ${ }^{380}$

$\mathrm{Na}$ nossa concepção, o exemplo europeu de licença parental a ser analisado com mais atenção é o da Suécia, primeiro país no mundo que transformou a licença-maternidade em um sistema de licença remunerada para mães e pais, justamente com a finalidade de incentivar os homens a assumirem papel mais ativo na criação de filhas e filhos e de "tornar mais igualitária a divisão de tarefas no âmbito doméstico". 381

A licença parental sueca (föräldraledighet) e o auxílio parental sueco (föräldrapenning) são concedidos após o nascimento ou adoção de uma criança em um total de 480 dias, o equivalente a 16 meses. ${ }^{382} \mathrm{O}$ auxílio parental equivale, nos primeiros 390 dias, a aproximadamente $80 \%$ do rendimento da pessoa beneficiada. Nos últimos 90 dias da licença, o benefício torna-se fixo e é reduzido a 180 Coroas Suecas por dia para o pai ou mãe (algo em torno de R $\$ 60,00) .{ }^{383}$

Não apenas pais e mães ${ }^{384}$ que trabalham no mercado formal têm direito ao benefício, mas também desempregadas, desempregados, estudantes e pessoas pobres ou sem renda. No caso do desemprego, o cálculo do benefício é feito com base nos últimos salários da pessoa; enquanto que estudantes e pessoas pobres ou sem renda têm direito a receber um valor mínimo de benefício, de 6.750,00 Coroas Suecas por mês (aproximadamente $\mathrm{R} \$ 2.250,00$ mensais). ${ }^{385}$

O total de 480 dias da licença é dividido igualmente entre pai e mãe, mas pode existir transferência de tempo de um para o outro, exceto os 60 dias da licença remunerada a $80 \%$ do salário, que são reservados para cada um e que necessariamente

\footnotetext{
${ }^{380}$ ADDATI, Laura; CASSIRER, Naomi; GILCHRIST, Katherine. Maternity and paternity at work: law and practice across the world. Genebra: OIT, 2014. p. 62-63.

${ }^{381}$ FARIA, Carlos Aurélio Pimenta de Faria. Entre marido e mulher, o Estado mete a colher: reconfigurando a divisão do trabalho doméstico na Suécia. Revista Brasileira de Ciências Sociais [online], v.17, n.48, p. 173-231, fev.2002. p. 173-174.

${ }^{382} \mathrm{O}$ direito aos 480 dias de licença parental não são obrigatoriamente gozados de modo ininterrupto, desde o nascimento da criança até seu $480^{\circ}$ dia de vida. O pai ou a mãe podem gozar da licença e do auxílio parental até que a criança complete 12 anos (equivalente à $5^{\text {a }}$ série do ensino fundamental sueco), com a limitação de que, tendo a criança completado 4 anos, só podem ser guardados 96 dias do total.

${ }^{383}$ FORSAKRINGSKASSAN. About parental benefits. Stockholm: Forsakringskassan, 2014. Disponível em: 〈http://www.forsakringskassan.se>. Acesso em: 16.ago.2014.

${ }^{384} \mathrm{O}$ sistema sueco também é válido para casais homoafetivos, de modo que usaremos os termos "pai/s" e "mãe/s" não apenas para retratar o homem e a mulher parte de um casal heterossexual, mas falando também de um casal formado por mãe e mãe ou por pai e pai. Ademais, o casal pode optar por se utilizar de frações da licença, de $75 \%, 50 \%, 25 \%$ ou $12,5 \%$.

${ }^{385}$ FORSAKRINGSKASSAN, op. cit.
} 
precisam ser gozados por esse membro do casal. ${ }^{386}$ Essa restrição foi uma das medidas criadas para evitar que a licença parental fosse totalmente transferida do pai para a mãe. Além da restrição de transferência, a Suécia ainda adotou um sistema de bônus para as famílias em que os pais gozassem dos 240 dias que lhe são de direito. ${ }^{387}$

Diante dessas medidas, houve uma melhora no desequilíbrio de gênero em relação ao gozo da licença parental: se em 1985, mulheres ficavam com 94\% dos dias de licença parental, enquanto os homens tiravam 6\%; em 2013, as mulheres tiraram $75 \%$ e os homens $25 \%$ dos dias de licença. ${ }^{388}$ Vale ressaltar que os períodos de uso exclusivo dos pais só foram introduzidos na legislação em 1995. ${ }^{389}$

Interessante notar que, mesmo com o aparato estatal para fomentar o compartilhamento igualitário das responsabilidades familiares, a divisão sexual do trabalho persiste na Suécia. Segundo Elisabeth Badinter, isso se deve ao fato de as políticas de igualdade serem favoráveis à parentalidade, mas muito menos favoráveis à carreira das mulheres. A autora identifica dois problemas principais: a desigualdade salarial e a concentração de $75 \%$ das trabalhadoras no setor público, enquanto a maioria dos homens está empregada no setor privado. Essa realidade faz com que seja mais vantajoso para a família, financeiramente e em termos de estabilidade no emprego, que a mulher assuma a maior parte da licença parental. ${ }^{390}$

A Espanha foi outro país que enfrentou dificuldades na tentativa de promoção da igualdade de gênero na divisão de responsabilidades com filhos e filhas, pois apesar da implantação de uma espécie licença parental pela Lei nº 39/1999, segundo a qual a mãe poderia ceder parte de sua licença-maternidade de 16 semanas ao cônjuge, com exceção das primeiras seis semanas, as mulheres continuaram fazendo o uso principal deste direito: segundo dados do Instituto Nacional de Seguridade Social

\footnotetext{
${ }^{386}$ FORSAKRINGSKASSAN. About parental benefits. Stockholm: Forsakringskassan, 2014. Disponível em: 〈http://www.forsakringskassan.se>. Acesso em: 16.ago.2014.

${ }^{387}$ ADDATI, Laura; CASSIRER, Naomi; GILCHRIST, Katherine. Maternity and paternity at work: law and practice across the world. Genebra: OIT, 2014. p. 63.

388 STATISTICS SWEDEN. Women and men in Sweden. Örebro: SCB, 2014. Disponível em: <http://www.scb.se/Statistik/_Publikationer/LE0201_2013B14_BR_X10BR1401ENG.pdf〉. Acesso em: 16.ago.2014.

389 FARIA, Carlos Aurélio Pimenta de Faria. Entre marido e mulher, o Estado mete a colher: reconfigurando a divisão do trabalho doméstico na Suécia. Revista Brasileira de Ciências Sociais [online], v.17, n.48, p. 173-231, fev.2002. p. 184.

${ }^{390}$ BADINTER, Elisabeth. O conflito: a mulher e a mãe. Rio de Janeiro: Record, 2011. p. 137-138.
} 
espanhol, em 2005, 98,24\% das licenças parentais e 95,23\% das licenças para cuidado de filhos e filhas foram solicitadas por mulheres. ${ }^{391}$

Tanto a realidade sueca quanto a espanhola demonstram que a simples introdução de medidas com o objetivo de permitir melhor conciliação entre responsabilidades familiares e profissionais para ambos os sexos faz com que, na prática, elas continuem sendo utilizadas predominantemente por mulheres, uma vez que, diferentemente da legislação, as práticas sociais e culturais são mais refratárias a mudanças. Na Suécia, como vimos, a tentativa de correção dessa distorção foi a fixação de períodos da licença parental que não podem ser transferidos entre o casal. Já a saída espanhola foi criar novas medidas que introduzissem a cultura da corresponsabilidade parental nos casais espanhóis, por meio da ampliação da licença-paternidade. ${ }^{392}$

Dessa forma, foi criada na Espanha, com a promulgação da Lei $n^{\circ}$. 3/2007 (Lei Orgânica para a Igualdade Efetiva entre Mulheres e Homens), a licençapaternidade os mesmos moldes da licença-maternidade, apesar de menor tempo de duração: "treze dias, ampliáveis nos casos de parto, adoção ou acolhimento múltiplos em dois dias a mais para cada filho a partir do segundo", sendo assinalado em disposição transitória que, passados seis anos, essa licença chegaria à duração de quatro semanas. ${ }^{393}$

Assim, a referida lei introduziu no Estatuto dos Trabalhadores espanhol uma nova causa de suspensão do contrato de trabalho, a paternidade, período que passou a ser pago pela Seguridade Social. O direito à licençapaternidade não se confunde, portanto, com a denominada "licença por nascimento de filho", que concede ao pai dois dias de dispensa do trabalho logo após o parto, pagos pelo empregador. Tampouco se confunde com a possibilidade de compartilhamento da licença-maternidade, pois se configura como um direito individual do pai de caráter intransferível. ${ }^{394}$

Dessa forma, observamos que, na Espanha, a alternativa legal encontrada para incentivar uma distribuição das responsabilidades familiares mais

\footnotetext{
${ }^{391}$ AGUILERA IZQUIERDO, Raquel. Los derechos de conciliación de la vida personal, familiar y laboral en la Ley Orgánica para la igualdad efectiva de mujeres y hombres. Revista Del Ministerio De Trabajo y Asuntos Sociales, Madrid, n. extra 2, p. 69-119, 2007. p. 72.

${ }^{392}$ Ibid., p. 72.

393 THOME, Candy Florêncio. A licença-paternidade como desdobramento da igualdade de gênero - um estudo comparativo entre Brasil e Espanha. Revista LTr, São Paulo, v. 74, n. 07, p. 832-838, jul.2010. p. 835.

${ }^{394}$ AGUILERA IZQUIERDO, Raquel, op. cit., p. 107.
} 
igualitária foi a somatória da licença-maternidade compartilhada com a licençapaternidade. Relevante mencionar que, segundo publicação da OIT, a licençapaternidade pode ser encontrada na legislação de pelo menos 78 países dos 167 que disponibilizam tais dados. Contudo, apenas cinco desses países concedem licenças de mais de duas semanas aos pais: Finlândia, Islândia, Lituânia, Portugal e Eslovênia. ${ }^{395}$ Segundo a mesma pesquisa,

(...) in almost all countries that offer paternity leave, fathers may choose whether to take the leave or not. Just three countries make paternity leave compulsory. Compulsory paternity leave helps to ensure that fathers share childcare responsibility with mothers and allows for greater involvement of men in the critical early stages of an infant's development (...). In Portugal, ten days of compulsory leave must be taken within 30 days of birth, five of which must be consecutive. Fathers have the option to take an additional ten days of paternity leave. ${ }^{396}$

Tais experiências internacionais podem servir de exemplos para a reconfiguração do Direito do Trabalho brasileiro no tocante à proteção da maternidade, uma vez que pensarmos em soluções como a espanhola - que permite o compartilhamento de parte da licença concedidas às mães e ainda concede aos pais um período um pouco mais longo de licença-paternidade, pago com benefício previdenciário - não nos parece utópico, mas sim bastante viável. Não podemos mais ignorar a necessidade de que direitos relativos ao cuidado da família precisam ser concedidos a todos os membros da família, para que possam ser compartilhados de forma mais igualitária, o que permitiria abandonar as bases sexistas da legislação e fomentar a igualdade de gênero no trabalho e nas relações familiares.

\subsubsection{Direito à creche}

As transformações na família ocorridas no Brasil nos anos 1970, com a expansão do emprego feminino que abalou o predomínio do modelo de provedor único masculino, não contaram com o apoio de um sistema de bem-estar articulado por parte do Estado, de modo que a socialização da reprodução foi fragmentada por meio de políticas parciais de pouca eficácia, deixando a responsabilidade pela reprodução

\footnotetext{
${ }^{395}$ ADDATI, Laura; CASSIRER, Naomi; GILCHRIST, Katherine. Maternity and paternity at work: law and practice across the world. Genebra: OIT, 2014. p. 53.

${ }^{396}$ Ibid., p. 56.
} 
cotidiana quase que totalmente a cargo das famílias, ou seja, das mulheres, que passaram a realizar de forma simultânea o trabalho doméstico não remunerado e o trabalho remunerado. ${ }^{397}$

A alternativa encontrada pelas mulheres da classe média e de parte das camadas populares para articular trabalho e família, segundo Elisete Bilac, foi o uso do modelo de delegação, ou seja, atribuir a outras mulheres, geralmente as empregadas domésticas, a realização de parte do trabalho doméstico e de cuidados. Outro caminho, também na esfera da delegação, foi contar com uma rede de solidariedade feminina, normalmente as vizinhas, avós, filhas mais velhas e outras parentas, ou ainda deixar as crianças se cuidarem sozinhas. No entanto, "nenhuma dessas soluções, marcadas pelo improviso, pela instabilidade e por enormes tensões, poderiam ser satisfatórias". 398

Dessa forma, especialmente para as mulheres das camadas mais populares, que não podem recorrer à contratação de babás ou outras profissionais para executarem a maior fração do trabalho doméstico, a oferta de serviços coletivos que permitam a socialização do trabalho de cuidados emerge como elemento diretamente relacionado à qualidade da presença feminina no mercado de trabalho. Isso vale, sobretudo, para as trabalhadoras-mães, uma vez que a falta desses serviços se reflete no uso desigual do tempo dedicado às atividades domésticas entre os sexos. ${ }^{399}$

Conforme Cristina Bruschini e Maria Rosa Lombardi, "a maternidade é um dos fatores que mais interferem no trabalho feminino, quando os filhos são pequenos", já que a responsabilidade pela guarda, cuidado e educação dos filhos e filhas continua sendo das mulheres, mesmo quando elas trabalham fora, o que limita a saúde e as energias das mulheres para o trabalho remunerado, "sobretudo se os rendimentos obtidos são insuficientes para cobrir custos com formas remuneradas de cuidado infantil". 400

O modo como a insuficiência de equipamentos coletivos para o cuidado contribui para aumentar o peso da maternidade sobre as trabalhadoras foi demonstrado por pesquisa publicada na International Labour Review, segundo a qual as atuais taxas

${ }^{397}$ BILAC, Elisabete. Trabalho e família: articulações possíveis. Tempo social [online], v.26, n.1, p. 129145, 2014. p. 130-131.

${ }^{398}$ Ibid., p. 131-132.

${ }^{399}$ SORJ, Bila; FONTES, Adriana; MACHADO, Danielle. Políticas e Práticas de conciliação entre família e trabalho no Brasil. Cadernos de Pesquisa, v.37, n. 132, p. 573-594, set/dez 2007. p. 576.

${ }^{400}$ BRUSCHINI, Cristina; LOMBARDI, Maria Rosa. Instruídas e trabalhadeiras. Cadernos Pagu, Campinas, n. 17-18, p. 157-196, 2002. p. 165. 
de participação laboral das mulheres nas economias industrializadas só se aproximaram das dos homens em locais onde existem creches públicas para as crianças pequenas, por exemplo na Escandinávia e na Europa oriental, concluindo que o emprego feminino aumentaria se houvesse a provisão de creches em maior número e mais baratas. ${ }^{401} \mathrm{De}$ acordo com a pesquisa, a saída das mulheres de seus empregos devido à gravidez ou cuidado da prole varia nos países europeus, o que está associado com "different levels and patterns of subsidized child care and other factors such as the length of the school day". 402

A necessidade da socialização do trabalho doméstico, especialmente de cuidados, é reconhecida na esfera jurídica internacional pela OIT, no anteriormente transcrito artigo $5^{\circ}$ da Convenção 156 da OIT, segundo o qual a efetiva igualdade entre homens e mulheres no trabalho depende de medidas para "desenvolver ou promover serviços comunitários, públicos ou privados, como serviços e meios de assistência à infância e família". ${ }^{403}$ Também a CEDAW trata da questão em seu artigo 11, no qual se afirma que, a fim impedir a discriminação contra as mulheres, os Estados-Partes da ONU devem tomar medidas para

$$
\begin{aligned}
& \text { (...) estimular o fornecimento de serviços sociais de apoio necessários } \\
& \text { para permitir que os pais combinem as obrigações para com a família } \\
& \text { com as responsabilidades do trabalho e a participação na vida pública, } \\
& \text { especialmente mediante fomento da criação e desenvolvimento de } \\
& \text { uma rede de serviços destinados ao cuidado das crianças. }{ }^{404}
\end{aligned}
$$

No Brasil, o artigo $7^{\circ}$, inciso XXV, da CF prevê como direito de todas as trabalhadoras e trabalhadores a assistência gratuita aos filhos, filhas e dependentes até cinco anos de idade em creches e pré-escolas. Além de direito da classe trabalhadora, o artigo 208, inciso IV da CF dispõe que é dever do Estado garantir a educação infantil, por meio de creches e pré-escolas. Somam-se às determinações constitucionais os já

\footnotetext{
${ }^{401}$ JOSHI, Heather; DAVIES, Hugh. Day care in Europe and mothers' forgone earnings. International Labour Review, Genebra, v.131, n. 6, p. 561-579, 1992. p. 561.

402 Ibid., p. 577.

403 ORGANIZAÇÃO INTERNACIONAL DO TRABALHO. Convenção 156, sobre a igualdade de oportunidades e de tratamento para homens e mulheres trabalhadores: trabalhadores com encargos de familiares. Genebra: OIT, 1981. Disponível em: < http://www.oitbrasil.org.br/content/sobre-igualdadede-oportunidades-e-de-tratamento-para-homens-e-mulheres-trabalhadores-trabal>. Acesso em: 16.ago.2014.

${ }^{404}$ ORGANIZAÇÃO DAS NAÇÕES UNIDAS. Convenção sobre a Eliminação de Todas as Formas de Violência contra a Mulher. New York: ONU, 1979. Disponível em: <http://www.planalto.gov.br/ccivil_03/decreto/2002/D4377.htm>. Acesso em: 28.jul.2014.
} 
mencionados artigo $389, \S 1^{\circ}$ e artigo 400 da CLT, que tratam do fornecimento de creches para guarda de filhos e filhas das trabalhadoras.

No entanto, a efetivação deste direito está longe de ser uma realidade: em 2009, das cerca de 10 milhões de crianças residentes no Brasil de 0 a 3 anos de idade, apenas $18,1 \%$ frequentavam creches, o que significa que mais de oito milhões de crianças nessa idade dependiam do cuidado privado. ${ }^{405}$ Ora, se parte das desigualdades de inserção no mercado de trabalho caracterizam regimes de cuidado diferenciados, ${ }^{406}$ que permitem que algumas mulheres externem o trabalho doméstico, mas a maioria ainda arque com boa parte dele, é preciso garantir que o direito à creche seja efetivado em nosso país.

Sobre essa questão, Cristiane Lopes Sbalqueiro afirma que o direito à creche não é um direito de índole meramente assistencial, mas é considerado "etapa inicial do direito à educação, garantido para todas as crianças, de seis meses até, pelo menos, o término do Ensino Fundamental". Segundo ela, a CF atribui ao Estado a tarefa de proporcionar creches e educação infantil, de modo que, sob o ponto de vista jurídico, "não se pode justificar a persistência de uma situação de desamparo à infância e/ou desigualdade da mulher no mercado de trabalho pela "falta de recursos orçamentários" para construir creches". ${ }^{407}$ Ademais, nas palavras da autora,

(...) não é verdade que a Constituição Federal tenha imposto o dever de garantir creches exclusivamente aos empregadores, como já expusemos neste trabalho. $\mathrm{O}$ simples fato de o art. $7^{\circ}$, que trata do direito dos trabalhadores, reproduzir a garantia que já está explícita no capítulo que versa sobre o direito à educação, não autoriza tal tipo de interpretação. Com efeito, também estão previstos no mesmo art. $7^{\circ}$, os direitos ao seguro-desemprego, ao salário-família e à aposentadoria, direitos esses que não são custeados exclusivamente pelo empresariado. Ao contrário, essas conquistas são suportadas especialmente pelos cofres públicos, apesar da contribuição dos interessados. Quando quis prever que uma contribuição seria custeada especificamente pelo empregador, a Constituição assim o fez (a garantia do seguro contra acidentes de trabalho, por exemplo). (...) Entendemos que o direito à creche existe e é exigível em face do Estado. Pode ser aprimorado por lei, e essa lei poderá até impor contribuição do empregador e dos trabalhadores para garantir a sustentabilidade de um sistema que se pretende universal. A inércia

\footnotetext{
${ }^{405}$ INSTITUTO BRASILEIRO DE GEOGRAFIA E ESTATÍTICA. Síntese de indicadores sociais: uma análise das condições de vida da população brasileira. Rio de Janeiro: IBGE, 2009. p. 143.

${ }^{406}$ SORJ, Bila. FONTES, Adriana. O care como um regime estratificado: implicações de gênero e classe social. In GUIMARÃES, N. A. HIRATA, H. S. (org.) Cuidado e cuidadoras: as várias faces do trabalho do care. São Paulo: Atlas, 2012. p. 114.

${ }^{407}$ LOPES, Cristiane Maria Sbalqueiro. A efetivação do direito à creche no Brasil. Revista do Ministério Público do Trabalho, Brasília, n. 40, p. 38-60, set.2010. p. 49.
} 
legislativa, no entanto, não inviabiliza a fruição desse direito, ainda que seja necessário recorrer à Justiça para garantir vagas na creche. ${ }^{408}$

Dessa maneira, a efetivação do direito à creche pública para todas as crianças, se possível em horários prolongados e abertas diariamente, é medida fundamental para a igualdade de gênero no trabalho, uma vez que é a única forma de garantir que as trabalhadoras socializem parte das responsabilidades que a divisão sexual do trabalho atribui a elas, para que possam dedicar-se ao trabalho remunerado sem que isso gere grande sobrecarga. Isso é dever do Estado.

Portanto, o combate à discriminação no trabalho por conta da maternidade exige uma política integrada que inclua a ratificação da Convenção 156 da OIT, sobre a igualdade de oportunidades e de tratamento para trabalhadoras e trabalhadores com encargos familiares, a atualização da legislação nacional para que favoreça o compartilhamento de tarefas entre homens e mulheres, especialmente por meio de medidas como o aumento da licença-paternidade e o desenvolvimento da licença parental, a elaboração de políticas públicas de socialização do cuidado, além do importante papel da Justiça do Trabalho, do Ministério do Trabalho e Emprego e dos sindicatos na garantia de que essas medidas sejam efetivadas.

Além da maternidade, outros estereótipos de gênero ainda influenciam o Direito do Trabalho, merecendo que sua construção histórica seja demonstrada e a lógica normativa alterada, como é o caso dos mitos em torno do corpo feminino e de sua maior fragilidade. Da mesma maneira, tal como a necessidade de proteção da saúde reprodutiva de todos os trabalhadores e trabalhadoras, não apenas das gestantes, outros temas que dizem respeito ao equilíbrio do meio ambiente de trabalho seguem invisibilizados, como inadequação de equipamentos e máquinas a pessoas que saem do "padrão de trabalhador", ou a influência das relações de gênero sobre a incidência de determinadas doenças ocupacionais nas mulheres. Sobre esses pontos que nos debruçaremos no próximo capítulo.

\footnotetext{
${ }^{408}$ LOPES, Cristiane Maria Sbalqueiro. A efetivação do direito à creche no Brasil. Revista do Ministério Público do Trabalho, Brasília, n. 40, p. 38-60, set.2010. p. 56.
} 


\section{Capítulo 4. Ergonomia e o corpo das mulheres em face dos riscos ocupacionais}

O equilíbrio do meio ambiente de trabalho depende da interação harmoniosa entre os diversos elementos que compõem este sistema, que podem ser tanto fatores que objetivamente oferecem risco à saúde e à segurança - como a exposição a substâncias químicas e compostos biológicos, ou a demanda por esforços físicos ou por movimentos que geram fadiga muscular - quanto fatores decorrentes da organização do trabalho e das relações humanas desenvolvidas dentro e fora do local de trabalho, conforme exposto no capítulo 1.

A compreensão sistêmica do meio ambiente de trabalho é a proposta da ergonomia, ciência que se propõe a analisar a relação entre as condições de trabalho e as características psicofisiológicas de trabalhadores e trabalhadoras e, a partir desta análise, propõe adaptações ao local de trabalho, a fim de proporcionar conforto, segurança e eficiência no trabalho, ou seja, o equilíbrio labor-ambiental, conforme indica a NR 17. Para isso, verificam-se todos os aspectos relacionados à organização do trabalho, ritmo de tarefas, condições ambientais dos postos, mobiliário, instrumentos de trabalho e necessidade de transporte ou levantamento de materiais.

Guilherme Guimarães Feliciano define ergonomia como “o conjunto de ciências e tecnologias aplicadas à adaptação confortável e produtiva do ser humano ao seu trabalho", cujo objetivo é "adaptar as condições de trabalho às características dos diferentes perfis antropométricos dos seres humanos". Segundo o autor, um ambiente de trabalho não estará equilibrado se não for dotado de "parâmetros ergonômicos adequados", de forma que é obrigação dos empregadores providenciar a análise ergonômica do trabalho, para garantir qualidade de vida de trabalhadoras e trabalhadores. $^{409}$

Entretanto, a maioria dos parâmetros ergonômicos se baseia em medidas masculinas, o que expõe as trabalhadoras a problemas físicos derivados diretamente da inadequação de medidas, bem como pode causar o aumento do estresse por falta de controle dos próprios equipamentos de trabalho e pela maior atenção demandada para a

\footnotetext{
${ }^{409}$ FELICIANO, Guilherme Guimarães. Meio ambiente do trabalho (aspectos gerais e propedêuticos). Revista do Tribunal Regional do Trabalho da $15^{a}$ Região, [online], v. 20, p. 1-49, 2002. Disponível em <http://portal.trt15.jus.br/documents/124965/125414/Rev20Art12.pdf/c44e2910-96d2-4d0a-9cc51c8e64720c2e>. Acesso em: 24.jun.2014. p. 19-20.
} 
realização do trabalho correto em meios inadequados. Ademais, a já abordada divisão estereotipada entre "trabalhos leves" de mulheres e "trabalhos pesados" de homens faz com que somente os riscos relacionados a este último tipo sejam visíveis, esquecendo-se muitas vezes dos riscos ocultos das tarefas aparentemente leves, mas que demandam rapidez e precisão. ${ }^{410}$

Além do mais, é preciso que se leve em consideração que o desenho dos postos de trabalho, desde a organização dos espaços e dos horários, até a formação de equipamentos e ferramentas, foi majoritariamente pensado a partir do padrão masculino de trabalhador. Exemplos disso são as ferramentas manuais de trabalho - desenhadas para se adequarem ao padrão anatômico dos homens - e a organização do tempo de trabalho, que parte de um modelo de disponibilidade que não é real para grande parte da força de trabalho, uma vez que não se levam em conta as responsabilidades familiares. $^{411}$

Partiremos dessas ideias para analisar como a perspectiva de gênero deve ser incorporada à ergonomia, de modo a permitir que o ambiente de trabalho seja adequado também às necessidades e características das trabalhadoras, a fim de que as causas de muitas das doenças ocupacionais que as afligem sejam enfrentadas adequadamente. Isso permite combater a ideologia que transforma o trabalhador ou trabalhadora em responsável pelos acidentes ou doenças que sofre, ao invés do sistema e da organização do trabalho, desvelando tanto o "mito do ato inseguro", que atribui acidentes ao "descuido" do indivíduo, ${ }^{412}$ quanto a lógica invertida que faz crer que o adoecimento é consequência da fragilidade física e psicológica pessoal.

\footnotetext{
${ }^{410}$ GONZÁLES GÓMEZ, Maria Fernanda. Salud laboral y género: Apuntes para la incorporación de la perspectiva de género en el ámbito de la prevención de riesgos laborales. Medicina y Seguridad del trabajo [online], v.57, supl.1, p. 89-114, 2011. p.97.

${ }^{411}$ ESPAÑA. Herramienta de apoyo $n^{o}$ 10: Salud y riesgos laborales con perspectiva de género. Madrid: Ministerio de Sanidad, Servicios Sociales e Igualdad, 2010. Disponível em: <http://www.igualdadenlaempresa.es/recursos/herramientas/home.htm>. Acesso em: 15.ago.2014. p.7.

${ }^{412}$ BARRETO, Margarida Maria Silveira. Violência, saúde e trabalho: uma jornada de humilhações. São Paulo: EDUC, 2013. p. 37-38.
} 


\subsection{O estereótipo de fragilidade das mulheres}

A convicção de que os corpos das mulheres são mais frágeis e delicados que os corpos dos homens é mais uma construção histórica atrelada às relações e estereótipos de gênero. De acordo com Maria das Graças Melo Fernandes,

até o século XVIII, o pensamento filosófico e médico da Europa acreditava na existência de um só sexo, o masculino. A mulher era seu representante inferior, sendo descrita como um homem invertido. (...) Essa concepção mudou no final do século XVIII, quando foi demarcada a criação da bissexualidade. É através da mudança de modelo de sexo-único para o modelo mais científico de dois sexos que (...) modificou-se radicalmente a interpretação dos corpos masculino e feminino - sendo este associado a metáforas negativas e patológicas. (...) a medicina, por meio de seus saberes particulares ou auxiliares, a exemplo da Anatomia, da Biologia e da Psiquiatria, começa a fornecer os argumentos necessários à transposição para o mundo da corporalidade de demarcações morais justificatórias de novas hierarquizações dos seres humanos. Nesse cenário, estruturas, como o esqueleto e o sistema nervoso, que antes eram comuns, agora, por meio de uma 'anatomia política', são diferentes, salientando uma inferioridade do corpo feminino. ${ }^{413}$

Desse modo, o pensamento sexista, apoiado no essencialismo e no biologicismo, confina as mulheres nas exigências biológicas da reprodução e atribui a elas uma maior corporalidade e proximidade com a natureza. Seguindo essa lógica, o sistema reprodutivo feminino constituiria a base da função social e das características comportamentais das mulheres, do que deriva um organismo mais frágil tanto física quanto intelectualmente. Segundo a autora, esse discurso desqualifica as mulheres enquanto pessoas e às subordina à função procriadora, uma vez que

a especificidade corporal das mulheres é usada para explicar e justificar as posições sociais e as capacidades cognitivas inferiores atribuídas às mulheres. Por implicação, os corpos das mulheres são presumidamente incapazes das realizações masculinas, sendo mais fracos, mais expostos a irregularidades (hormonais), intrusões e imprevistos. ${ }^{414}$

De acordo com a autora, "muitas das assertivas sobre a suposta incapacidade da mulher frente ao trabalho se devem mais a preconceitos que a fatos

\footnotetext{
${ }^{413}$ FERNANDES, Maria das Graças Melo. O corpo e a construção das desigualdades de gênero pela ciência. Revista de Saúde Pública, Rio de Janeiro, v. 19, n. 4, p. 1051-1065, 2009. p. 1053-1054.

${ }^{414}$ Ibid., p.1062.
} 
científicos devidamente comprovados". ${ }^{415}$ Isso fica claro quando notamos o recorte de classe das primeiras construções teóricas acerca da fragilidade das mulheres, datadas do século XIX, que já era denunciado pelas mulheres da época, ao afirmarem que os médicos "não se preocupavam em condenar o desgaste físico das trabalhadoras de classes inferiores, interessando-se somente pelas mulheres das classes médias". ${ }^{16}$

A esse respeito, Elisabeth Meloni Vieira afirma que o mito da fragilidade feminina, no século XIX, "serviria às mulheres da elite, já que as da classe trabalhadora na Inglaterra tinham jornadas de trabalho de até 14 horas diárias”. Isso tem relação com a expansão da Medicina como profissão liberal, a serviço da sociedade que podia pagar honorários, de modo que a "natureza feminina" precisava explicar as necessidades médicas de acordo com a classe da mulher atendida. Exemplo disso é que o discurso médico da época diferenciava o parto de mulheres da corte e da província: "no primeiro caso, o parto é laborioso e excessivamente doloroso; no segundo, o parto é mais rápido e, apesar de doloroso, o choque nervoso encontra um organismo que não se deixa abater". 417

No mesmo sentido, a tese de José Joaquim Firmino Júnior, de 1840, localizada nas pesquisas de Fabiola Rohden entre as teses defendidas na Faculdade de Medicina do Rio de Janeiro no final do século XIX - ao tratar do sistema de diferenças entre mulheres e homens, não apenas descreve como características masculinas o raciocínio, a força física e o movimento, e como características femininas a reprodução, o repouso e a quietude, mas também diferencia os sexos em termos fisiológicos, afirmando que

(...) os músculos na mulher são mais fracos, pequenos e delgados e terminam em tendões mais finos. Não são feitos para suportar grandes esforços. Uma espécie de atrofia fisiológica ataca os músculos do corpo feminino, com exceção daqueles que circundam a bacia e as coxas, importantes no processo de reprodução. No homem, o sistema sanguíneo predomina, tornando-o mais bem dotado de grandes forças físicas e morais, além de uma constituição rígida e seca. Na mulher, o sistema linfático torna-se preeminente, transformando-a em um ser mais mole e úmido. ${ }^{418}$

\footnotetext{
415 TUDOR, Talitha do Carmo. Trabalho da mulher - estágio atual. Revista Brasileira de Saúde Ocupacional, Ministério do Trabalho / Fundacentro, v. 38, n.10, p. 43-47, abr/mai/jun.1982. p. 38-39.

${ }^{416}$ ROHDEN, Fabíola. Uma ciência da diferença: sexo e gênero na medicina da mulher. Rio de Janeiro: Editora FIOCRUZ, 2001. p.91.

${ }^{417}$ VIEIRA, Elisabeth Meloni. A medicalização do corpo feminino. Rio de Janeiro: Editora FIOCRUZ, 2002. p. 37.

${ }^{418}$ ROHDEN, Fabíola, op. cit., p.123.
} 
Apesar de a Biologia e a Medicina terem evoluído muito daquela época até os dias de hoje, bem como a mentalidade em relação ao lugar das mulheres na sociedade, os moldes das relações de gênero e a divisão sexual do trabalho se mantêm, ainda que com diferentes características, e a falta dessa perspectiva histórica faz com que a ciência médica ainda traga consigo o estereótipo da fragilidade feminina. Disso decorre a importância de a Medicina incorporar também a dimensão de gênero, uma vez que ela interfere inclusive nos diagnósticos e tratamento de doenças, conforme defende a cardiologista Vera Regitz-Zagrosek, ao afirmar que algumas doenças, como osteoporose e depressão, são subdiagnosticadas nos homens por serem consideradas "doenças femininas". 419

Anne Fausto-Sterling toma justamente o exemplo da osteoporose para demonstrar como a ideia de fragilidade feminina está intrínseca à análise médica. Segundo ela, o dado global de que a osteoporose ocorre em uma frequência quatro vezes maior nas mulheres que nos homens depende de como esta doença é definida, em quais populações humanas são colhidas as estatísticas e quais os estágios da vida considerados. ${ }^{420}$ A autora afirma que

(...) part of the initial logic of thinking about osteoporosis as a basic biological (sex) difference between men and women derives from the observation that bone thinning increases dramatically around the time of menopause. Most thus assume that declining estrogen causes bone loss. Since estrogen codes in most people's minds as a quintessentially female molecule, it becomes extraordinarily difficult to conceptualize osteoporosis as a disease with many contributors stretching over the entire life cycle. Here, gender constructs combined with the profits derived from selling estrogen replacement have contributed mightily to shaping the course of scientific research in this field. Estrogen, though, is only one of a number of hormones linked to bone physiology". ${ }^{421}$

Além disso, Anne Fauto-Sterling afirma ser necessário que se analise as interações entre vários outros fatores, além do hormonal, que afetam a formação dos ossos. Ela elenca sete sistemas que contribuem para o fortalecimento ósseo ao longo do ciclo de vida, afirmando que cada um deles pode ser analisado em si como um sistema

\footnotetext{
${ }^{419}$ REGITZ-ZAGROSEK, Vera. Sex and gender differences in health. Science \& Society, New York, v.13, n.7, p. 596-603, 2012. p. 597.

${ }^{420}$ FAUSTO-STERLING, Anne. The Bare Bones of Sex: Part 1 - Sex and Gender. Signs: Journal of Women in Culture and Society, Chicago, v. 30, n.2, p. 1491-1527, 2005. p. 1500.

${ }^{421}$ Ibid., p. 1507-08.
} 
complexo: atividade física, alimentação, fármacos, formação óssea no desenvolvimento fetal, hormônios, metabolismo ósseo celular e efeitos biomecânicos na formação óssea. Segundo ela, "bone strength emerges from the interrelated actions of each (and all) of these systems as they act throughout the life cycle". ${ }^{422}$ Portanto, o rótulo de "doença feminina" está muito mais relacionado à forma como socialmente são entendidos os corpos das mulheres do que a comprovações científicas.

Desse modo, as doenças femininas de hoje guardam o sexismo de outrora e servem para justificar (ainda que de modo inconsciente) o status quo do gênero, não existindo nada de novo nas pesquisas "científicas" que buscam constatar essa fragilidade a todo custo, seja medindo os ossos e pesando cérebros, como era feito nos séculos passados, seja usando avançados exames clínicos e de neurociência. Por conseguinte, a divisão sexual de tarefas não se vincula à capacidade física ou intelectual das mulheres, "mas é constitutiva do que elas devem fazer, arbitrariamente, segundo uma imagem social da condição feminina". 423

Esse raciocínio vale também para a Medicina e o Direito do Trabalho, de modo que é preciso reconhecer os aspectos de gênero relacionados aos acidentes e doenças profissionais. A segregação das mulheres em profissões "femininas", que aparentam menores riscos, faz supor que elas não sofrem tantos danos à saúde quanto os homens. No entanto, esse entendimento muitas vezes é falso, pois existem setores em que a participação das mulheres é maciça e os riscos à saúde muito altos, mas pouco reconhecidos. É o caso, por exemplo, das trabalhadoras da área de saúde e das varredoras de rua. ${ }^{424}$

A segregação profissional também é uma das hipóteses para explicar as diferenças no padrão de adoecimento de homens e mulheres mostradas pela literatura especializada em saúde e segurança: estas apresentam maiores taxas de morbidade, enquanto os primeiros apresentam maiores taxas de mortalidade. ${ }^{425}$ Outra hipótese que

\footnotetext{
${ }^{422}$ FAUSTO-STERLING, Anne. The Bare Bones of Sex: Part 1 - Sex and Gender. Signs: Journal of Women in Culture and Society, Chicago, v. 30, n.2, p. 1491-1527, 2005. p. 1513.

${ }^{423}$ COUTINHO, Aldacy Rachid. Relações de gênero no mercado de trabalho: uma abordagem da discriminação positiva e inversa. Revista da Faculdade de Direito da Universidade Federal do Paraná, Curitiba, v. 34, p. 13-34, 2000. p. 13.

${ }^{424}$ BARROSO, Carmem. Trabalho e Saúde da Mulher. Revista Brasileira de Saúde Ocupacional, Ministério do Trabalho / Fundacentro, v. 38, n. 10, p. 7-11, abr/mai/jun.1982. p. 7-11.

${ }^{425}$ VIDAL, Renata de Queiroz Santana; NETO, Annibal Muiz Silvany. Trabalhadoras brasileiras: características socioeconômicas e ocupacionais e perfil de saúde, Brasil, 2003. Revista Brasileira de Saúde Ocupacional, São Paulo, v.34, n.120, p.115-127, jul./dez.2009. p.124.
} 
Marina Ferreira Réa levanta, para explicar tais dados, está no fato de que as mulheres falam mais de seus sintomas físicos e psicológicos, usam mais remédios e frequentam mais os serviços de saúde. Ademais, a maior morbidade das mulheres também poderia estar relacionada à construção da feminilidade, que determina mais atenção aos sintomas e maior preocupação com os cuidados preventivos. ${ }^{426}$ Nada relacionado, portanto, com uma maior fragilidade do organismo feminino à exposição aos riscos ocupacionais.

Essas conclusões nos servirão de base para demonstrarmos que o mito da fragilidade feminina também está presente em algumas normas do Direito do Trabalho que pretendem dar proteção à saúde e segurança das trabalhadoras, mas geram limitação das possibilidades de emprego das mulheres e, portanto, exclusão. Por conseguinte, é preciso que tais disposições sejam repensadas para que, caso se revelem apenas fruto dos estereótipos de gênero, sejam revogadas, ou, caso se demonstrem de fato necessárias para a proteção da integridade do organismo humano, sejam estendidas aos homens.

\subsubsection{A divisão sexual dos limites de carga}

A fixação dos limites de carga para levantamento de peso é uma das normas brasileiras de saúde e segurança no trabalho que fazem expressa diferenciação no tratamento de homens e mulheres. De acordo com os artigos 198 e 390 da CLT, é de 60 quilos "o peso máximo que um empregado pode remover individualmente", mas as mulheres não podem ser empregadas em serviços que demandem "emprego de força muscular superior a 20 (vinte) quilos para o trabalho continuo, ou 25 (vinte e cinco) quilos para o trabalho ocasional". De modo complementar, a NR 17, sobre ergonomia, no item 17.2.5, determina que "quando mulheres e trabalhadores jovens forem designados para o transporte manual de cargas, o peso máximo destas cargas deverá ser nitidamente inferior àquele admitido para os homens".

Esta diferenciação é normalmente apontada como um caso de diferenciação justa entre homens e mulheres, que não configuraria, portanto, discriminação. No entanto, sob a perspectiva proposta no tópico anterior, é preciso

\footnotetext{
${ }^{426}$ RÉA, Marina Ferreira. Benefícios à mãe trabalhadora: conquistas e recuos nas políticas públicas. In: BRUSCHINI, Cristina; UNBEHAUM, Sandra G. (orgs.). Gênero,democracia e sociedade brasileira. São Paulo: FCC: Editora 34, 2002. p. 389-402.
} 
questionar a ideia presente na legislação de que, a priori, as mulheres conseguem erguer menos peso que os homens. Se este "fato" é de conhecimento geral, também é de conhecimento geral que os seres humanos são muito diferentes entre si, uma vez que também existem homens franzinos, de baixa estatura, bem como mulheres fortes, grandes e com estrutura física bem desenvolvida.

Diante dessa realidade, cabem os questionamentos trazidos por Cristiane Maria Sbalqueiro Lopes: "que mulher tinha em mente o legislador, quando estabeleceu os limites máximos de 20 e 25 quilos?" e "por que o mesmo dispositivo não protege homens franzinos?". Se considerarmos que, devido à variabilidade humana, os limites de esforço físico que cada pessoa suporta também variam, de maneira que a regra consolidada, se tinha por objetivo preservar a saúde de trabalhadoras e trabalhadores, é ineficaz. $^{427}$

Desse modo, é preciso perceber que, sob uma roupagem protetiva, o que a legislação faz é restringir o acesso das mulheres a determinados setores e serviços, da mesma forma que ocorria com as já revogadas proibições do emprego de mulheres no trabalho noturno, em subterrâneos, em obras de construção e nas atividades perigosas e insalubres. Inclusive, cabe frisar que a limitação de carga do artigo 390 da CLT, tanto quanto as proibições dos artigos 379 e 387, têm origem no Decreto no. 21.417-A, de 1932, regras que foram incorporadas à CLT desde sua criação, em 1943. Sintomático que apenas o artigo 390 continue em vigor.

Sobre a questão, vale mencionar o raciocínio de Homero Batista Mateus da Silva, segundo o qual

a afirmação de que as mulheres são frágeis e os homens são fortes segue uma máxima bastante genérica, com base em padrões do ser humano médio, e não deveria servir para justificar a expressa vedação a que uma mulher se candidate ao posto de conferente de carga, por exemplo. Limita o espaço disponível das atividades econômicas, em concorrência desleal dos homens, sem que nem ao menos a pessoa tenha tido a chance de fazer um teste ou poder comprovar que, no particular, sua estrutura óssea era superior à média. Conquanto a proibição taxativa a que uma mulher trabalhe em construção civil tenha sido revogada, pois assim chegou a constar no art. 387 da CLT, segue vigente o art. 390, que veda ao empregador usar mão-de-obra feminina para movimentação de carga superior a vinte quilos - vinte e cinco, se ocasional. Assim, um empregador pode de antemão desprezar as candidaturas femininas para o trabalho da atividade-fim

\footnotetext{
${ }^{427}$ LOPES, Cristiane Maria Sbalqueiro. Direito do trabalho da mulher: da proteção à promoção. Cadernos Pagu, Campinas, n. 26, p. 405-430, 2006. p. 419-420.
} 
de uma pedreira ou de uma transportadora de cargas pesadas, com apoio na CLT. ${ }^{428}$

Ademais, como observado por Margarida Barreto, o fato de tanto homens quanto mulheres chegarem ao final da jornada de trabalho com dores na coluna e cansaço generalizado demonstra que, apesar de a legislação prever menores pesos para o uso da força muscular das mulheres, a relação saúde-doença para as trabalhadoras decorre muito mais da "sobrecarga imposta pelo ritmo de trabalho" do que da massa do material manuseado. ${ }^{429}$

Interessante mencionar exemplo revelando que o nível de esforço das mulheres no carregamento de peso, apesar de invisível, pode ser tão ou mais prejudicial que esforço dos homens, mesmo quando respeitados os limites legais para cada sexo. De acordo com a pesquisa realizada por Simone Oliveira em uma fábrica, apesar de todas e todos do local afirmarem que "pegar peso" é prejudicial, apenas para os homens esse problema era reconhecido como exigência da atividade e considerado pela chefia como carente de solução. Entretanto, verificou-se que as mulheres empurravam caixas cujo peso chegava a 60 quilos, o que, por não fazer parte do conjunto de tarefas prescritas para o setor, era ignorado pela chefia, como ficou patente na fala de um dos gerentes: "as meninas do empeçamento pegam aquelas caixas pesadas... eu falo com elas, deixem isso, que nem homem pega isso". Segundo a autora, porém, se elas seguissem esse conselho, a seção pararia de funcionar. ${ }^{430}$

Em termos científicos, também não fica claro quais são os critérios que determinam os 20 ou 25 quilos de limite de carga para as mulheres, sendo muito provável que sejam pesos estipulados com base na percepção social da fragilidade feminina, não em estudos técnicos. Inclusive, conforme relata Valentina Forastieri, estudos recentes que buscaram estimar os limites para levantamento e carregamento de peso para mulheres e homens no trabalho, baseadas em dados antropométricos de

\footnotetext{
${ }^{428}$ SILVA, Homero Batista Mateus da. Direito do Trabalho Aplicado, vol. 3: Segurança e medicina do trabalho, trabalho da mulher e do menor. Rio de Janeiro: Elsevier, 2009. p. 153-154.

${ }^{429}$ BARRETO, Margarida. O trabalho engendrando doenças e diferenças. In: BARRETO, Margarida; CARLOTO, Cássia Maria; COSTA, Maria Luiza da. Saúde das Trabalhadoras. São Paulo: SOF Sempreviva Organização Feminista, 1998. p. 59-79. p.63.

${ }^{430}$ OLIVEIRA, Simone. Gênero, Organização do Trabalho e Saúde. In: Encontro Nacional de Engenharia de Produção, 1997, Rio de Janeiro. Anais do ENEGEP 1997. Rio de Janeiro: ABEPRO, 1997. 9p. p.4.
} 
pessoas anglo-saxãs brancas, "mostraram que a faixa de capacidade de ambos os grupos foi muito similar". ${ }^{431}$ A esse respeito, a autora afirma que

(...) the concept of maximum weight to be manually handled by women and the design of personal protective equipment need to be revised in the context of current technical knowledge and socio-medical trends. Intra-sex variations need to be taken into account. National standards for manual handling should move away from regulating weight limits which differ between women and men workers and adopt a non discriminatory approach based on individual risk assessment and control. Australia, Canada, and the USA are some of the countries which have introduced this criteria in their own standards. With the worldwide massive migration, it is becoming more and more evident that anthropometric standards need to based on human variability more than on "model" populations, as different racial and ethnical morphological characteristics can be found among the workers of any single country. ${ }^{432}$

A defasagem desse tipo de diferenciação é reconhecida pela própria OIT, que fez constar no documento oficial da Convenção 127, sobre peso máximo das cargas, ${ }^{433}$ de 1967, que se trata de um "instrumento a ser revisado". ${ }^{434}$ De acordo com o artigo VII, item 2, da convenção, "quando mulheres e trabalhadores jovens forem designados para o transporte normal de cargas, o peso máximo destas cargas deverá ser nitidamente inferior àquele admitido para os homens".

De maneira similar, a ACGIH aboliu as distinções de sexo ao estipular os valores limites de exposição (TVLs) para levantamento de peso no local de trabalho. Para este caso, os TVLs "consistem em três tabelas com limites de peso em quilogramas (kg) para duas mãos e tarefas de monoelevação", ou seja, para casos em que a tarefa do levantamento de peso é a única realizada em determinado dia de trabalho, calculados por sua duração (inferior ou superior a duas horas por dia) e frequência (número de levantamentos por hora). ${ }^{435}$

\footnotetext{
${ }^{431}$ Tradução livre de "have shown that the capacity range for both groups was very similar". FORASTIERI, Valentina. Women workers and gender issues on occupational safety and health: Information Note. Genebra: OIT, 2010. p. 5.

${ }^{432}$ FORASTIERI, Valentina. Women workers and gender issues on occupational safety and health: Information Note. Genebra: OIT, 2010. p.10.

${ }^{433}$ Tradução livre da autora. Adotada pela OIT em 1967; ratificada pelo Brasil em 21/08/1970.

434 Conforme pode ser visto em <http://www.ilo.org/dyn/normlex/en/f?p=NORMLEXPUB: 12100:0::NO::P12100_ILO_CODE:C127>. Acesso em: 15.ago.2014.

${ }^{435}$ ACGIH. 2011: TVLs \& BEIs. Tradução: Associação Brasileira de Higienistas Ocupacionais. São Paulo: ABHO, 2011. p. 205.
} 
Elencam-se, ainda, os fatores ou condições de trabalho que demandariam a redução do limite de peso recomendado nos TVLs: alta frequência de levantamento de peso; turnos de trabalho estendidos, com levantamentos de peso por período maior de 8 horas diárias; alta assimetria, que é considerado o levantamento com grau de inclinação do corpo superior a $30^{\circ}$; movimentos de levantamento rápidos e movimentos de torção; levantamento com uma mão; postura corporal inferior forçada; umidade e calor elevados; elevação de objetos instáveis; acoplamento inadequado das mãos; pico instável; e vibração de corpo inteiro. Portanto, em momento nenhum ACGIH faz diferenciação entre os limites para o levantamento de peso para homens e mulheres. ${ }^{436}$

Concluímos, assim, pela necessidade de revogação da regra contida no artigo 390 da CLT, tomando como parâmetro as normas da ACGIH, que não fazem diferenciação entre os sexos no caso de limitação de cargas. Com isso, o artigo 198 da CLT passaria a ser aplicado a trabalhadores e trabalhadoras, submetendo a apreciação de cada caso "às condições pessoais da empregada, ao tempo consumido na atividade, às condições do serviço", ${ }^{437}$ com escopo no artigo 483, alínea $a$, da CLT. ${ }^{438}$

\subsubsection{O intervalo de 15 minutos pré-jornada extraordinária}

Tal como a diferenciação entre os limites de carga para o trabalho de homens e mulheres, do já analisado artigo 390 da CLT, a determinação específica para o trabalho feminino de que "em caso de prorrogação do horário normal, será obrigatório um descanso de 15 (quinze) minutos no mínimo, antes do início do período extraordinário do trabalho", do artigo 384, tem como base o mesmo argumento sexista da fragilidade dos corpos das mulheres. Consequentemente, as bases gerais de nosso raciocínio a respeito dessa normativa são as mesmas demonstradas no tópico anterior.

De todo modo, alguns aspectos deste dispositivo merecem ser pontuados. O primeiro deles é o fato de o artigo 384 integrar a CLT, com a exata mesma redação, desde a sua compilação, em 1943. Naquele momento, além dele, outros dois

\footnotetext{
436 ACGIH. 2011: TVLs \& BEIs. Tradução: Associação Brasileira de Higienistas Ocupacionais. São Paulo: ABHO, 2011. p.205-206.

${ }^{437}$ BARROS, Alice Monteiro de. O trabalho da mulher: revisão de conceitos. In: PENIDO, Laís de Oliveira (coord.). Igualdade dos gêneros nas relações de trabalho. Brasília: ESMPU, 2006. p. 51-82; p. 56.

438 BRASIL. Consolidação das Leis do Trabalho. Artigo 483. "O empregado poderá considerar rescindido o contrato e pleitear a devida indenização quando: a) forem exigidos serviços superiores às suas forças, defesos por lei, contrários aos bons costumes, ou alheios ao contrato".
} 
dispositivos tratavam da jornada extraordinária das mulheres: o artigo 375, que dispunha que "mulher nenhuma poderá ter o seu horário de trabalho prorrogado, sem que esteja para isso autorizada por atestado médico oficial, constante de sua carteira profissional" e; o artigo 376, que determinava que apenas em casos excepcionais, por motivo de força maior, a jornada das trabalhadoras poderia ser prorrogada.

Da análise conjunta dessas disposições, infere-se que o intervalo de 15 minutos aplicava-se à excepcionalidade do cumprimento de horas extraordinárias de alguma trabalhadora. Tendo ambos os artigos sido revogados em decorrência da promulgação da CF, o primeiro pela Lei $\mathrm{n}^{\circ}$. 7.855 , de 1989 , e o segundo pela Lei $\mathrm{n}^{\circ}$. 10.244 , de 2001, muito provavelmente, não era a proposta original do legislador que o artigo 384 passasse a ser aplicado de forma ampla. Além disso, se o fundamento do intervalo de 15 minutos era proteger a saúde "mais frágil” das trabalhadoras, "esse assunto perdeu boa parte de seu impacto com a completa banalização das horas extras no Direito do Trabalho brasileiro". 439

Crítica das medidas especiais de higiene e segurança da CLT, Alice Monteiro de Barros aponta que os principais fundamentos dessa norma eram "biológicos, provenientes da debilidade física", bem como afirma que a proibição do trabalho extraordinário das mulheres baseava-se em razões "espirituais, morais e familiares, que a rigor residem no resguardo da mulher no lar". ${ }^{440}$ Por conseguinte, e por considerar que o artigo 376 traduzia "um obstáculo legal que impede o acesso igualitário da mulher no mercado de trabalho", o entendimento da autora, ainda antes da Lei de 2001, era de que ambos os artigos deveriam ser revogados, por conflitarem com o artigo $5^{\circ}$, inciso I, e artigo $7^{\circ}$, inciso XXX, da CF. ${ }^{441}$

O segundo aspecto que precisamos pontuar envolve a discussão acerca da recepção ou não recepção do artigo 384 da CLT pela CF - por colidir com o princípio constitucional da igualdade (artigo $5^{\circ}$, inciso I e artigo $7^{\circ}$, inciso XXX) - e, em caso de recepção, se a regra poderia ser estendida aos homens trabalhadores, tomando como base a igualdade de direitos entre os sexos e o princípio da não discriminação.

A este respeito, o entendimento mantido pelo do TST ao longo dos anos, de que a previsão do repouso de 15 minutos pré-jornada extraordinária trata-se de uma

\footnotetext{
${ }^{439}$ SILVA, Homero Batista Mateus da. Direito do Trabalho Aplicado, vol. 3: Segurança e medicina do trabalho, trabalho da mulher e do menor. Rio de Janeiro: Elsevier, 2009. p. 161.

${ }^{440}$ BARROS, Alice Monteiro de. A mulher e o Direito do Trabalho. São Paulo: LTr, 1995, p. 36.

${ }^{441}$ Ibid., p. 479.
} 
forma de discriminação válida ${ }^{442} 443$, foi referendado pelo STF no final de 2014, com o julgamento do Recurso Extraordinário $\mathrm{n}^{\mathrm{o}}$. 658.312, no qual ficou definido que "o art. 384 da CLT foi recepcionado pela Constituição Federal de 1988 e que a norma se aplica a todas as mulheres trabalhadoras". 444

O relator, Ministro Dias Toffoli, partindo da compreensão de que a previsão constitucional de que "homens e mulheres são iguais em direitos e obrigações" inclui a possibilidade de tratamento diferenciado, afirma que o artigo 384 da CLT levou em consideração dois critérios de diferenciação: "a histórica exclusão da mulher do mercado regular de trabalho", que impôs ao Estado a implantação de medidas "de natureza protetora no âmbito do direito do trabalho"; e a existência de "um componente orgânico, biológico, a justificar o tratamento diferenciado, inclusive pela menor resistência física da mulher", 445

Tomando como base esses dois pontos, o voto prossegue afirmando que,

(...) o legislador entendeu que deveria manter a regra do art. $384 \mathrm{da}$ CLT, a fim de lhe garantir uma diferenciada proteção, dada a identidade biossocial peculiar da mulher e da sua potencial condição de mãe, gestante ou administradora do lar. Aliás, não há como negar que há diferenças quanto à capacidade física das mulheres em relação aos homens (....). ${ }^{446}$

Como demonstrado ao longo deste trabalho, entendemos que há, sim, como negar a existência de diferenças, em sentido amplo, quanto à capacidade física das

\footnotetext{
442 "RECURSO DE REVISTA DA RECLAMANTE. INTERVALO PREVISTO NO ARTIGO 384 DA CLT. PROTEÇÃO AO TRABALHO DA MULHER. Nos termos da jurisprudência desta Corte Superior, a disposição contida no artigo 384 da CLT foi recepcionada pela Constituição Federal. Assim, homens e mulheres, embora iguais em direitos e obrigações, diferenciam-se em alguns pontos, especialmente no que concerne ao aspecto fisiológico, merecendo, portanto, a mulher um tratamento diferenciado quando o trabalho lhe exige um desgaste físico maior, como nas ocasiões em que presta horas extras. Por essa razão, faz jus ao intervalo de quinze minutos antes do início do período extraordinário. Precedentes. Recurso de revista conhecido e provido." (BRASIL. Tribunal Superior do Trabalho. $8^{\mathrm{a}}$ Turma. RR 96893.2012.5.04.0512. Relatora: Dora Maria da Costa. Diário da Justiça Eletrônico 19.set.2014)

443 “AGRAVO DE INTRUMENTO EM RECURSO DE REVISTA. INTERVALO DO ARTIGO 384 DA CLT. A controvérsia em torno da adequação constitucional do art. 384 da CLT foi dirimida pelo Tribunal Superior do Trabalho no julgamento do IIN-RR-1540/2005-046-12-00, ocasião em que se decidiu pela observância da norma consolidada. Nesse contexto, a não concessão do intervalo previsto no mencionado art. 384 da CLT implica o pagamento de horas extras correspondentes àquele período, uma vez que se trata de medida de higiene, saúde e segurança do trabalhador (art. $7^{\circ}$, XXII, da Constituição Federal). Agravo de instrumento não provido." (BRASIL. Tribunal Superior do Trabalho. $7^{\mathrm{a}}$ Turma. AIRR 1007743.2013.5.18.0016. Relator: Douglas Alencar Rodrigues. Diário da Justiça Eletrônico 19.set.2014)

${ }^{444}$ BRASIL. STF. Recurso Extraordinário $n^{\circ}$. 658.312/SC. Voto do Relator, Ministro Dias Toffoli. Julgado em 27.nov.2014. p. 14.

${ }^{445}$ Ibid., p. 4.

${ }^{446}$ Ibid., p. 5.
} 
mulheres em relação aos homens. Ademais, nossos estudos também demonstraram que não há algo como a "identidade biossocial peculiar da mulher" - uma vez que as mulheres são bastante plurais, tanto em termos físicos, quanto sociais - e que não se pode tratar as mulheres trabalhadoras apenas como mães em potencial.

Assim, observamos que o julgamento do STF baseou-se em fundamentos biologicistas que reiteradamente aqui buscamos afastar. Ademais, o relator inverte o foco da discussão, afirmando que "não há notícia da existência de levantamento técnico ou científico a demonstrar que o empregador prefira contratar homens, em vez de mulheres, em virtude da obrigação em comento". ${ }^{447}$ Em contrapartida, o próprio relator não nega o dado empírico de que, com ou sem o dispositivo, as mulheres sofrem discriminação no emprego.

A esse respeito, a justificativa do PL $\mathrm{n}^{\circ}$. 1.455, de 1999, que se transformou na Lei $\mathrm{n}^{\circ}$. 10.244, de 2001, era justamente de que a revogação do artigo 376 da CLT fazia-se necessária por ferir o princípio da isonomia e "prejudicar o próprio mercado de trabalho da mulher, na medida em que a correlação dessa mão-de-obra pode se tornar não atrativa, em razão da restrição sob comento", o que fazia dela uma proteção indevida e inconstitucional. ${ }^{448}$

O mesmo argumento pode ser usado para a extensão do artigo 384 aos trabalhadores do sexo masculino - ou, em último caso, para sua revogação -, pois o intervalo de 15 minutos também é motivo para empregadores considerarem o emprego de mulheres mais oneroso, preterindo-as em relação aos homens. Cabe, aqui, o seguinte exemplo:

Imagine se (...) uma indústria que trabalhe em linha de produção. Se a regra for uniforme, num ou noutro sentido, ela deverá cessar os trabalhos por 15 minutos para que todos recuperem as energias e iniciem a sobrejornada ou continuar o labor de forma ininterrupta. Contudo, se houver tratamento distinto em relação ao gênero, a empresa, no momento da contratação, decidirá se prefere aqueles a quem a lei permite prestar horas extras imediatamente após o término da jornada ou os que devem descansar por 15 minutos, sob pena de pagamento do período suprimido como hora extra. Não é preciso muito esforço especulativo para prever as consequências. ${ }^{449}$

\footnotetext{
${ }^{447}$ BRASIL. STF. Recurso Extraordinário no ${ }^{\circ}$ 658.312/SC. Voto do Relator, Ministro Dias Toffoli. Julgado em 27.nov.2014. p. 7.

448 BRASIL. Câmara dos Deputados. Disponível em: <http://www.camara.gov.br/proposicoesWeb/ fichadetramitacao?idProposicao=16752>. Acesso em: 15.ago.2014.

${ }^{449}$ HIGA, Flavio da Costa; VIEIRA, Regina Stela Corrêa. Proteção ou discriminação? Passando a limpo algumas normas de tutela do trabalho da mulher. Revista do Tribunal Superior do Trabalho, v. 21, n.1, Rio de Janeiro, p. 56-72, set./dez.2013. p. 70.
} 
Dessa forma, o que deveríamos buscar são comprovações científicas que embasem afirmações como a do relator, de que "o trabalho contínuo impõe à mulher o necessário período de descanso, a fim de que ela possa se recuperar e se manter apta a prosseguir com suas atividades laborais em regulares condições de segurança". ${ }^{450}$ Entretanto, não há registros de estudos demonstrando que a realização dessa pausa de fato diminua os riscos de acidentes ou doenças provocados pelo excesso de jornada. Tampouco existem pesquisas atestando que a medida é eficaz apenas da proteção de pessoas do sexo feminino, mas que não traria benefícios para saúde de pessoas do sexo masculino.

A respeito de que a suposta intenção do legislador era diminuir os impactos danosos à saúde causados pelo esgotamento físico e mental da jornada extraordinária, reflete Homero Batista Mateus da Silva que,

(...) a bem da verdade, esse assunto seria pertinente tanto aos empregados do sexo masculino quanto para a proteção do trabalho da mulher. No entanto, o legislador considerou o assunto restrito à fragilidade maior do organismo feminino e não contemplou os homens com semelhante dispositivo. Logo, é incorreta a afirmação de que a pausa de quinze minutos se prende a uma questão de segurança do trabalho - pois seria universal e não sectário (...). ${ }^{451}$

Nesse sentido, se a limitação da jornada em oito horas diárias e 44 horas semanais tem como objetivo preservar a saúde de trabalhadores e trabalhadoras, não há dúvida de que o ideal seria que ninguém cumprisse horário extraordinário. Assim, se a concessão de 15 minutos de intervalo entre o término da jornada ordinária e o início da extraordinária realmente reduz os impactos perversos dessa prorrogação, deveria ser estendida também aos homens.

Dessa forma, eventual interpretação conforme a Constituição para contemplar os homens nesta garantia "não implicaria atuação como legislador positivo, já que o problema reside unicamente na inserção topológica, por estar o dispositivo inserido no capítulo de proteção ao trabalho da mulher", questão que pode ser interpretada como de segunda ordem, por dizer respeito apenas à compilação. ${ }^{452}$

\footnotetext{
${ }^{450}$ BRASIL. STF. Recurso Extraordinário no ${ }^{\circ}$ 658.312/SC. Voto do Relator, Ministro Dias Toffoli. Julgado em 27.nov.2014. p. 13.

${ }^{451}$ Ibid., p. 161.

${ }^{452}$ HIGA, Flavio da Costa; VIEIRA, Regina Stela Corrêa. Proteção ou discriminação? Passando a limpo algumas normas de tutela do trabalho da mulher? Revista do Tribunal Superior do Trabalho, v. 21, n.1, Rio de Janeiro, p. 56-72, set./dez.2013. p. 69.
} 
Seja como for, a realidade que se constata na Justiça do Trabalho é que, em toda a discussão sobre a aplicação ou não do artigo 384 da CLT, poucos se importam de fato com a preservação da saúde de homens e mulheres, pois o interesse majoritário gira em torno da necessidade de indenizar o intervalo de 15 minutos não gozado pelas trabalhadoras - fato que inclusive moveu a empresa recorrente do Recurso Extraordinário, pois fora condenada em segunda instância ao pagamento "de quinze minutos com adicional de 50\%". ${ }^{453}$ Estamos, portanto, diante de um direito que foi desviado de seu foco protetivo, ficando reduzido à pecúnia no sistema jurídico trabalhista.

\subsection{A inadequação de maquinário e equipamentos para trabalhadoras}

O objetivo das normas de proteção à saúde e segurança no trabalho é de adaptar o trabalho ao ser humano, não o inverso. No entanto, é bastante comum que o maquinário seja projetado de acordo com os padrões de altura masculinos, que os instrumentos de trabalho usem como parâmetro as proporções anatômicas de homens e, por mais grave que seja, que os equipamentos de proteção individual sejam moldados a partir de medidas masculinas, fazendo com que as mulheres tenham maiores dificuldades na execução de suas tarefas e fiquem expostas a maiores riscos ocupacionais.

No que se refere às máquinas e equipamentos industriais, é preciso destacar que eles, geralmente, "são concebidos para os homens, sendo frequentemente inadequados e extenuantes para as mulheres (e homens de pequena estatura)". ${ }^{454} \mathrm{~A}$ inadequação é ainda mais grave no caso brasileiro, uma vez que a maioria das máquinas utilizadas nas empresas são importadas, não guardando relação "sequer com as medidas antropométricas da população brasileira", o que favorece a ocorrência de acidentes. ${ }^{455}$

De acordo com a OIT,

\footnotetext{
${ }^{453}$ BRASIL. STF. Recurso Extraordinário no $\mathrm{n}^{\mathrm{o}}$ 658.312/SC. Voto do Relator, Ministro Dias Toffoli. Julgado em 27.nov.2014. p. 1.

454 ORGANIZAÇÃO INTERNACIONAL DO TRABALHO. $O$ ABC dos direitos das mulheres trabalhadoras e da igualdade de género. Genebra: OIT, 2007. p. 176.

${ }^{455}$ BARRETO, Margarida. O trabalho engendrando doenças e diferenças. In: BARRETO, Margarida; CARLOTO, Cássia Maria; COSTA, Maria Luiza da. Saúde das Trabalhadoras. São Paulo: SOF Sempreviva Organização Feminista, 1998. p. 59-79. p.64.
} 
(...) lesões por uso de equipamentos mecânicos representam um percentual elevado de todos os acidentes de trabalho em todas as ocupações. O design dos equipamentos e ferramentas tem demonstrado ser uma das principais causas de lesão, uma vez que não são concebidos ou projetados corretamente, em especial na indústria manufatureira. No design dos equipamentos e ferramentas utilizados, os dados antropométricos nem sempre refletem as características da população ativa que irá usá-lo. ${ }^{456}$

Além do maquinário, a "maioria dos equipamentos de proteção individual (...) utilizados no mundo é projetada com base na população masculina da Alemanha e dos Estados Unidos". Ignora-se, assim, a existência de uma variabilidade significativa tanto entre as populações desses países, quanto nas de outros países, ${ }^{457} \mathrm{o}$ que significa que tanto trabalhadoras quanto trabalhadores que não se enquadram nesses padrões, por terem estatura mais baixam ou serem mais franzinos, "não estão, portanto, devidamente equipados para o desempenho de suas funções dentro de padrões aceitáveis de proteção e segurança". ${ }^{458}$

Em relação aos problemas de adaptação dos EPI, a posição da Associação Nacional da Indústria de Material de Segurança e Proteção ao Trabalho (ANIMASEG) é de que cabe aos empregadores a compra adequada dos equipamentos de acordo com sua força de trabalho, mas que há empresas que "não têm esse conhecimento e focam nos produtos mais baratos, sem se darem conta dos problemas posteriores". Cita o exemplo das luvas de proteção, pois a maioria das empresas adquire equipamentos em tamanho único, que ficam ideiais para homens, mas grandes para mulheres. $^{459}$

É preciso ainda ressaltar que a inadequação dos EPI ou seu uso inadequado torna-se ainda mais grave devido à cultura brasileira de monetização dos riscos ocupacionais, que transformou o uso desses equipamentos, previsto na NR 6 como medida emergencial, em medida definitiva e obrigatória. Dessa forma as empresas se eximem de corrigir ou minimizar os riscos presentes no ambiente de

\footnotetext{
${ }^{456}$ ORGANIZAÇÃO INTERNACIONAL DO TRABALHO. Módulo de capacitação em inspeção do trabalho e igualdade de gênero. Brasília: OIT, 2012. p. 71.

${ }^{457}$ FORASTIERI, Valentina. Women workers and gender issues on occupational safety and health: Information Note. Genebra: OIT, 2010. p. 6.

${ }^{458}$ ORGANIZAÇÃO INTERNACIONAL DO TRABALHO, op. cit., p. 71.

${ }^{459}$ MENDES, Aline. Olhar diferenciado: homens e mulheres têm necessidades distintas no trabalho. Revista Proteção, n. 174, ano XIX, jun/2006. p. 30-46.
} 
trabalho, ao mesmo tempo em que trabalhadoras e trabalhadores sadios tornam-se intoxicados, doentes, asmáticos, surdos e mutilados. ${ }^{460}$

Frente à inadequação dos EPI para as mulheres, não adiantaria falarmos na necessidade de fiscalização do seu fornecimento e uso, uma vez que, além de não protegerem as trabalhadoras como devido, podem aumentar os riscos de acidentes. A única solução avistada é a inversão da lógica de proteção que impera no Brasil, exigindo-se que as empresas eliminem os riscos labor-ambientais ou, quando impossível fazê-lo, que invistam em sua redução e na aplicação de medidas de proteção coletivas. Além disso, a correta orientação de trabalhadoras e trabalhadores em relação à sua saúde e segurança é fundamental.

\subsection{LER/DORT e o mito da "doença feminina"}

O estudo ergonômico do meio ambiente do trabalho é de fundamental importância para a identificação de fatores de sobrecarga desencadeados pela execução de determinadas tarefas de maneira repetida e no ritmo imposto pela organização do trabalho, que podem gerar fadiga muscular e psicológica e os quadros dolorosos característicos das LER/DORT ${ }^{461}$. A incidência de sintomas relacionados a esse distúrbio em trabalhadoras e trabalhadores demonstra desequilíbrio labor-ambiental. ${ }^{462}$

A relação entre as LER/DORT, gênero e trabalho merece ser investigada, pois é na população de mulheres que a maioria dos casos é diagnosticada. Quando evidenciada a questão de gênero, que determina a segregação profissional por sexo, com menor grau de controle sobre as tarefas das funções "femininas", como visto no capítulo 1, torna-se explicíta a construção social dos padrões de adoecimento, mediada

\footnotetext{
${ }^{460}$ BARRETO, Margarida. O trabalho engendrando doenças e diferenças. In: BARRETO, Margarida; CARLOTO, Cássia Maria; COSTA, Maria Luiza da. Saúde das Trabalhadoras. São Paulo: SOF Sempreviva Organização Feminista, 1998. p. 59-79. p.67.

${ }^{461}$ Como registro metodológico, esclarecemos que a opção do presente estudo pela utilização da nomenclatura "LER/DORT" tem como base a atual Norma Técnica do INSS sobre o tema, aprovada pela Instrução Normativa INSS/DC n. 98, de 2003, que expressamente optou pelo uso da terminologia "Lesões por Esforços Repetitivos/ Distúrbios Osteomusculares Relacionados ao Trabalho (LER/DORT)", bem como por ser a designação utilizada pelo Ministério da Saúde do Brasil, no "Manual de Procedimentos para os Serviços de Saúde”, de 2001.

${ }^{462}$ FELICIANO, Guilherme Guimarães. Meio ambiente do trabalho (aspectos gerais e propedêuticos). Revista do Tribunal Regional do Trabalho da $15^{a}$ Região, [online], v. 20, p. 1-49, 2002. Disponível em <http://portal.trt15.jus.br/documents/124965/125414/Rev20Art12.pdf/c44e2910-96d2-4d0a-9cc51c8e64720c2e>. Acesso em: 24.jun.2014. p. 21-22.
} 
pela composição da força de trabalho exposta ao risco, especialmente no caso das lesões por esforços repetitivos.

Como os postos de trabalho que exigem execução de movimentos repetitivos dos dedos, mãos e braços, com atenção redobrada e ritmo intenso, são destinados preferencialmente às mulheres, o desgaste sobre elas, apesar de lento e pouco perceptível no início, transforma-se com o passar do tempo em dores, choques e formigamentos que assombram suas vidas, pois não apenas dificultam a execução de atividades laborais, como também impedem o trabalho doméstico. $O$ fato de não conseguirem mais corresponder às expectativas, tanto dos empregadores quanto da família, implica forte sofrimento psíquico. ${ }^{463}$

As LER/DORT designam "distúrbios musculoesqueléticos ocupacionais de origem multifatorial complexa", resultantes de "um desequilíbrio entre as exigências das tarefas realizadas no trabalho e as capacidades funcionais individuais para responder a essas exigências", referentes "a uma gama de doenças inflamatórias e degenerativas do aparelho locomotor", dentre as quais inflamações dos tendões de antebraços, punhos e ombros, mialgias, dores no pescoço, e degenerações na coluna. ${ }^{464}$

Interessante dizer que estes tipos de distúrbios musculoesqueléticos, que comprometem tanto a coluna cervical quanto os membros superiores, têm sua possível relação com o trabalho apontada nos relatados na literatura médica desde o século XVIII, com a publicação do livro "As Doenças dos Trabalhadores”, de Bernardo Ramazzini, marco inicial na história da Medicina do Trabalho. ${ }^{465}$

No Brasil, as LER/DORT foram reconhecidas como doença do trabalho pela Previdência Social pela Portaria ${ }^{\circ}$. 4.062 , de 1987, possibilitando a percepção de benefícios. Atualmente, os parâmetros do INSS com relação aos distúrbios estão delimitados na "Norma Técnica sobre Lesões por Esforços Repetitivos-LER ou Distúrbios Osteomusculares Relacionados ao Trabalho-DORT", aprovada pela Instrução Normativa INSS/DC nº. 98, de 2003.

\footnotetext{
${ }^{463}$ MAENO, Maria. LER/DORT: Problema de mulheres. In: INSTITUTO LATINOAMERICANO DE EDUCAÇÃO INTEGRAL. Um olhar de gênero na saúde e segurança no trabalho, ILEI, São Paulo, nov.2005. p. 18-19.

${ }^{464}$ ASSUNÇÃO, Ada Ávila; VILELA, Lailah Vasconcelos Oliveira. Lesões por esforços repetitivos: guia para profissionais de saúde. Piracicaba: Centro de Referência em Saúde do Trabalhador - CEREST, 2009. p. 20.

${ }^{465}$ CHEREM, Alfredo Jorge; COIMBRA, Alexandre. Doenças osteomusculares relacionadas com o trabalho: membro superior e pescoço. In: MENDES, René (org.). Patologia do Trabalho. $3^{\mathrm{a}}$ ed. São Paulo: Atheneu, 2013. p. 1391-1421. p. 1392.
} 
Atualmente, o Decreto $\mathrm{n}^{\mathrm{o}}$. 3.048, de 1999, identifica como os agentes patogênicos causadores de doenças profissionais ou do trabalho as "posições forçadas e gestos repetitivos", "ritmo de trabalho penoso" e "condições difíceis de trabalho". Estes fatores de risco são predominantemente relacionados ao desenvolvimento de doenças do sistema osteomuscular e do tecido conjuntivo (Grupo XIII da CID-10), dentre as quais: artroses e dor articular; dorsalgia e cervicalgia; sinovites e tenossinovites, dedo em gatilho; transtornos dos tecidos moles relacionados com o uso, o uso excessivo e a pressão, de origem ocupacional; bursite da mão, do cotovelo, pré-rotulianas e outras bursites; lesões do ombro e tendinite bicipital.

As LER/DORT são atualmente as doenças de maior notificação do país, conforme aponta o Anuário Estatístico da Previdência Social, de 2013. Naquele ano, os CID mais incidentes foram "lesões no ombro (M75), sinovite e tenossinovite (M65) e dorsalgia (M54), com 21,08\%, 13,85\% e 6,93\%, do total". ${ }^{466}$ Sob o recorte de sexo, o levantamento de Cássia Maria Carloto indica que "de cada dez pessoas com LER, oito são mulheres". ${ }^{467}$ Nesse sentido, publicação do Ministério da Saúde revelou que "vários serviços de atenção à saúde do trabalhador, entre os quais o Núcleo de Saúde do Trabalhador de Belo Horizonte e o Centro de Referência em Saúde do Trabalhador de São Paulo, apresentam entre seus pacientes uma maior prevalência de mulheres acometidas de LER/DORT", 468

Pelo seu caráter endêmico, desde o reconhecimento de seus primeiros casos, as LER/DORT foram relacionadas ao corpo das mulheres, tendo muitos autores de áreas da saúde vinculado a incidência da doença em mulheres a fatores hormonais, a características morfológicas e anatômicas, e a fatores psíquicos, como neuroses e histeria. Popularizou-se, assim, a ideia de que a LER/DORT seria uma doença feminina, inclusive dentro das empresas, conforme relato de Margarida Barreto:

São comuns os comentários discriminatórios por parte de encarregados, chefias, médicos e colegas, como: 'LER é coisa de mulher'; 'LER é doença de lerdas'; (...) 'por que não casa com um homem rico e resolve ser problema para sempre?'; 'isso é só cansaço, não é nada grave, muita gente tem problema mais grave que o seu e trabalha normal'; 'isso você pegou fazendo tricô em casa, isso se pega

\footnotetext{
${ }^{466}$ BRASIL. Anuário Estatístico da Previdência Social: AEPS 2013. Brasília: Ministério da Previdência Social, 2012. p. 532.

${ }^{467}$ CARLOTO, Cássia Maria. A saúde das trabalhadoras. In: BARRETO, Margarida; CARLOTO, Cássia Maria; COSTA, Maria Luiza da. Saúde das Trabalhadoras. São Paulo: SOF Sempreviva Organização Feminista, 1998. p. 9-37. p. 19.

${ }^{468}$ BRASIL. LER/DORT: dilemas, polêmicas e dúvidas. Brasília: Ministério da Saúde, 2001. p. 17.
} 
até na cozinha'; 'só você fica doente, as outras têm mais tempo aqui e nada aconteceu'; 'queria saber o que você tem com esse médico, que só lhe afasta'. ${ }^{469}$

As teorias que consideram as LER/DORT como "doença feminina" baseiam-se no vago conceito de que há uma predisposição ligada ao sexo, ou seja, existiria uma patogenicidade inata das mulheres a esses distúrbios. Argumentam que sua maior incidência na população do sexo feminino estaria relacionada a "fatores hormonais, características anatômicas e morfológicas, fatores da esfera psíquica como neuroses de compensação e histeria, culpa, estrutura da personalidade". ${ }^{770}$

Argumentos como esse "fortalecem a desvalorização da força de trabalho feminina, acentuando as discriminações de gênero e não considerando as exigências diferenciadas impostas nas relações e organização sexual do trabalho", ${ }^{471}$ e servem, “intencionalmente ou não, para alimentar preconceitos e discriminações e culpabilizar o adoecido pelo próprio adoecimento". ${ }^{472}$ Nesse sentido, Herval Pina Ribeiro afirma que

(...) invalidar pessoas que têm sofrimento, sempre solitário, e que lidam com medos, ameaças e perdas, não é difícil. Mais fácil ainda se é mulher. Vai da insinuação pouco sutil de estar ou ser nervosa, ao xingamento escrachado de estar louca. As LER são ditas manifestações psicológicas, significando uma debilidade intrínseca do adoecido, logo sua auto culpabilidade. E como os adoecidos, em sua maioria, são mulheres, as LER passam a ser coisa de mulher, expressão carregada de preconceito que mal disfarça a estratégia de inibir a revelação da doença por parte dos homens. ${ }^{43^{3}}$

Desse modo, a redução das LER/DORT à condição de fenômeno biológico e individual, juntamente com o discurso psicologizante e de fragilidade feminina acabam por culpabilizar as trabalhadoras, tirando das empresas a responsabilidade pelo adoecimento. ${ }^{474}$ Volta à pauta, assim, a necessidade de

\footnotetext{
${ }^{469}$ BARRETO, Margarida. Lesões por esforços repetitivos (LER): que danos causam no cotidiano das mulheres. In: OLIVEIRA, Eleonora Menicucci de; SCAVONE, Lucila. (org). Trabalho, Saúde e Gênero na era da globalização. Goiânia: AB Editora, 1997. p. 87- 100.

${ }^{470}$ OLIVEIRA, Eleonora Menicucci de; BARRETO, Margarida. Engendrando gênero na compreensão das lesões por esforços repetitivos. Saúde e Sociedade [online], v.6, n.1, p. 77-99, 1997. p. 87.

${ }^{471}$ Ibid., p. 87.

472 RIBEIRO, Herval Pina. Lesões por esforços repetitivos (LER): uma doença emblemática. Cadernos de Saúde Pública, Rio de Janeiro, v.13, Supl. 2, p. 85-93, 1997. p. 92.

${ }^{473}$ Ibid., p. 90.

${ }^{474}$ NEVES, Ilídio Roda. LER: trabalho, exclusão, dor, sofrimento e relação de gênero. Um estudo com trabalhadoras atendidas num serviço público de saúde. Cadernos de Saúde Pública, Rio de Janeiro, v. 22, n. 6, p. 1257-1265, jun.2006. p. 1263.
} 
combatermos o mito do ato inseguro, de forma a denunciar que "a impropriedade do adoecimento não está na pessoa, posto que lhe é externa, mas no trabalho". 475

$\mathrm{O}$ adoecimento no trabalho, por LER/DORT ou qualquer outra enfermidade, não decorre de "nenhum defeito ontogenético ou de caracteres depreciativos, de natureza biológica ou psíquica, mas objetivamente do trabalho", ${ }^{476}$ do mesmo modo que não é mero acaso a concentração das mulheres em postos de trabalho extenuante, repetitivo e de baixo nível hierárquico.

Portanto, como já afirmado por Helena Hirata, se as mulheres são alvo privilegiado das LER/DORT, "não é por causa de sua morfologia", tampouco "de fatores hormonais incidindo sobre sua construção biológica e psicológica (puberdade, gravidez, menopausa), mas porque a organização do trabalho as exclui em massa da concepção e da decisão". ${ }^{477}$ Nestes casos, a desigualdade de gênero revela seu lado mais trágico. $^{478}$

Interessante ressaltar que as saídas normalmente propostas em esfera ocupacional, especialmente por órgãos como o Ministério do Trabalho e Emprego e Ministério Público do Trabalho, como a mudança de mobiliário e a ginástica laboral, apesar de darem aparência de solução, têm sido pouco eficientes na prevenção do adoecimento das mulheres. ${ }^{479}$ Mais uma vez, é necessária a sensibilização, não apenas do Direito do Trabalho, mas de seus operadores, para que fique visível que as LER/DORT não são problemas de mulheres por serem mulheres, mas sim por estarem inseridas de determinada forma no mercado de trabalho, de modo que a abordagem preventiva precisa ter como foco todo o processo produtivo.

\footnotetext{
${ }^{475}$ RIBEIRO, Herval Pina Lesões por esforços repetitivos (LER): uma doença emblemática. Cadernos de Saúde Pública, Rio de Janeiro, v.13, Supl. 2, p. 85-93, 1997. p. 92.

${ }^{476}$ Ibid., p. 92.

${ }^{477}$ HIRATA, Helena. Reestruturação produtiva, trabalho e relações de gênero. Revista Latino-Americana de Estudos do Trabalho, ano 4, n. 7, p. 5-27, 1998. p. 19-20.

${ }^{478}$ SALIM, Celso Amorim. Doenças do Trabalho: exclusão, segregação e relações de gênero. São Paulo em Perspectiva [online], v. 17, n. 1, p. 11-24, 2003. p. 21.

${ }^{479}$ MAENO, Maria. LER/DORT: Problema de mulheres. In: INSTITUTO LATINOAMERICANO DE EDUCAÇÃO INTEGRAL. Um olhar de gênero na saúde e segurança no trabalho, ILEI, São Paulo, nov.2005. p. 18-19.
} 


\subsection{O paradigma da variabilidade humana individual}

A proposta deste capítulo foi de observar a saúde e segurança no trabalho das mulheres com enfoque tanto em seus corpos, quanto nas atividades por elas exercidas e nos tipos de adoecimento mais comuns a elas. Buscamos, assim, nos aproximar da orientação da ergonomia de analisar a "atividade como método, tendo como procedimentos fundamentais a observação e o diálogo com os trabalhadores" ${ }^{480} \mathrm{e}$ trabalhadoras, de modo a integrar outras dimensões da realidade de cada indivíduo, especialmente fatores sociais e econômicos.

Para nossa proposta de análise dos acidentes e do adoecimento com o enfoque de gênero, interessa especialmente o pressuposto ergonômico da variabilidade intraindividual. Entende-se que, por mais homogênea que seja a equipe de trabalho, cada trabalhadora ou trabalhador possui um organismo particular e vivencia diferentes experiências, dentro e fora do ambiente de trabalho. Por conseguinte, o que a ergonomia propõe é a análise das características reais dos integrantes da força de trabalho e qual o contexto da atividade a ser desempenhada, a fim de elaborar um planejamento para o equilíbrio do meio ambiente do trabalho como um todo, sem exceções. ${ }^{481}$

Sendo assim, observa-se um descompasso de nosso Direito do Trabalho com as propostas ergonômicas, uma vez que, conforme já verificamos, grande parte da normativa de saúde e segurança adota como referência a noção de "ser humano médio", o que exclui uma boa parte da população trabalhadora, especialmente as mulheres. Diante da variabilidade humana, adotar a "média" como parâmetro significa aceitar que algumas pessoas sejam mais expostas a riscos ocupacionais que outras.

Nesse sentido, a própria OIT sugere, dentre as formas de se inserir o gênero na normativa trabalhista, que as considerações ergonômicas, como as normas que estabelecem pesos máximos ou limites de movimentação manual, "devem ser desviadas da fixação de diferentes limites para trabalhadores e trabalhadoras para um sistema que se baseie na variabilidade humana individual, qualquer que seja o sexo, a idade ou as características étnicas". Desse modo, a proteção legal especial das mulheres

\footnotetext{
${ }^{480}$ BRITO, Jussara C. de; MATTOS, Ubirajara; SOARES, Vanda D’A.; FERREIRA, Heloisa P. Saúde das trabalhadoras: o caso da lavanderia de uma indústria química de cloro-soda. Cadernos de Saúde Pública, Rio de Janeiro, v. 11, n. 4, p. 543-551, out/dez 1995. p. 545.

${ }^{481}$ ABRAHÃO, Júlia Issy; MASCIA, Fausto Leopoldo; MONTEDO, Uiara Bandineli; SZNELWAR, Laerte Idal. Contribuição da ergonomia para a transformação e melhoria da organização e do conteúdo do trabalho. In: MENDES, René (org.). Patologia do Trabalho. 3a ed. São Paulo: Atheneu, 2013. p. 16391654. p. 1644.
} 
trabalhadoras "não deve ser invalidada, mas antes alargada aos trabalhadores do sexo masculino, quando apropriado, como, por exemplo, no caso da proteção contra as radiações e da saúde reprodutiva". ${ }^{482}$

Diferente, porém, é a adoção dos limites de tolerância de que trata a NR 15, conceituados em seu texto como "concentração ou intensidade máxima ou mínima, relacionada com a natureza e o tempo de exposição ao agente, que não causará dano à saúde do trabalhador, durante a sua vida laboral" (item 15.1.5). É preciso esclarecer que, apesar de a definição normativa permitir compreensão equivocada de que tudo aquilo que não ultrapassar o valor do referido "limite" é tolerado pelo organismo humano e não oferece risco, na verdade os limites de tolerância não são padrões absolutos.

Nos termos da ACGIH, limite de tolerância é o patamar que "se acredita, à luz dos conceitos contemporâneos" que a "maioria dos trabalhadores" possa estar exposta sem efeitos deletérios. Dessa forma, admite-se que o limite de segurança é a "presunção normativa" para a "população média", de modo que deve ser tomado como parâmetro a ser considerado juntamente com a variabilidade individual, uma vez que se reconhece a existência de pessoas hipo e hipersensíveis a determinados agentes.

Portanto, os limites de segurança não são "o fator" que estipula a linha entre saúde e doença, equilíbrio e risco, no trabalho. Devem, sim, ser um dos fatores a serem considerados na análise ergonômica do meio ambiente do trabalho, juntamente com outra multiplicidade de variações internas e externas do processo produtivo. De todo modo, os atuais limites de tolerância fixados nos anexos da NR 15 precisam ser questionados, pois deveriam ser atualizados de acordo com os avanços do conhecimento técnico sobre o adoecimento ocupacional, determinação esta que não é cumprida.

482 ORGANIZAÇÃO INTERNACIONAL DO TRABALHO. $O$ ABC dos direitos das mulheres trabalhadoras e da igualdade de género. 2 ed. Genebra: OIT, 2007. p. 178-179. 


\section{Capítulo 5. A saúde mental das mulheres trabalhadoras}

As normas brasileiras de saúde e segurança no trabalho abarcam não apenas a saúde física, mas também psíquica. Nesse sentido, a NR 17, sobre ergonomia, define como seu objetivo estabelecer parâmetros que levem em conta as características psicofisiológicas de trabalhadores e trabalhadoras para proporcionar um ambiente de trabalho com conforto, segurança e eficiência (item 17.1), o que é reforçado ao longo do texto normativo nos itens 17.5.1 e 17.6.1, segundo os quais as condições ambientais de trabalho "devem estar adequadas às características psicofisiológicas dos trabalhadores e à natureza do trabalho a ser executado".

De modo mais específico, o Decreto $n^{\circ}$. 3.048, de 1999, ao relacionar em seu anexo os agentes patogênicos causadores de doenças profissionais ou do trabalho, em respeito ao artigo 20 da Lei $n^{\circ}$. 8.213, de 1991, aborda também a saúde mental (Grupo V da CID-10). Na lista, estão relacionados transtornos mentais e comportamentais devidos ao uso de álcool, reações ao estresse e estado de estresse póstraumático, transtornos de sono e síndrome do esgotamento profissional ou "burn-out", elencando entre os fatores de risco para seu desenvolvimento "circunstância relativa às condições de trabalho", "ritmo de trabalho penoso" e "outras dificuldades físicas e mentais relacionadas com o trabalho".

Se considerarmos, como fizemos nos demais capítulos, que o trabalho das mulheres sofre influência de um conjunto de fatores sociais que interagem dentro e fora do ambiente laboral, em especial as relações de gênero, o bem-estar das trabalhadoras não decorre apenas de sua saúde física e reprodutiva, mas também de sua saúde mental. No entanto, para investigar os fatores ambientais que interferem na psique das mulheres, é preciso, em um primeiro momento, desconstruir estereótipos sexistas de que as mulheres seriam emocionalmente mais instáveis que os homens, o que gera preconceito entre os empregadores e maiores barreiras para a igualdade no trabalho.

\subsection{A construção sexista da instabilidade feminina}

Retomando a história da construção das diferenças sexuais feitas pela Medicina, como tratado no capítulo 1, vimos que ao final do século XIX - momento em que os médicos buscavam respostas para as mudanças sociais, especialmente as 
reivindicações das mulheres por direito e por trabalho - era comum que mulheres que transgredissem os padrões da feminilidade ditados socialmente fossem diagnosticadas como doentes. Desse modo, o comportamento das mulheres voltado à busca pela emancipação era submetido a interpretações psicologizantes e naturalistas, manifestadas por meio de representações sociais como a "tempestade hormonal", a ausência de certos hormônios, a "síndrome do útero vazio" e o "temperamento histérico", muitas das quais perduram até hoje. ${ }^{483}$

$\mathrm{O}$ corpo e a sexualidade das mulheres eram vinculados à loucura, a uma predisposição à doença mental, marcadas pelos estereótipos de feminilidade daquele período. ${ }^{484}$ Apesar de os médicos reconhecerem semelhanças entre órgãos e tecidos de homens e mulheres, preocupavam-se em explicar a doçura e as virtudes femininas, mas ao mesmo tempo multiplicavam suas patologias, explicados pelo "predomínio do seu sistema genital". 485

Para a ginecologia da época, as mulheres eram governadas por sua fisiologia, a qual era inerentemente psicológica, avolumando-se argumentos "científicos" para comprovar as qualidades distintas de cada sexo: as capacidades intelectuais seriam características dos homens, devido às medidas do crânio e ao tamanho do cérebro; já as mulheres, dominadas pelas funções sexuais, eram caracterizadas como instintivas e emotivas. ${ }^{486}$

A figura da "mulher histérica", alvo de grandes investimentos médicos naquele século, é bastante representativa nesse sentido. A histeria - termo cunhado por Hipócrates, derivado da palavra grega para útero, hystero ${ }^{487}$ - era explicada pela "natureza feminina", atribuída ao útero e aos nervos: a mulher histérica sofreria de manifestações exteriores à sua vontade, expressas pela exacerbação de sua sexualidade e

\footnotetext{
${ }^{483}$ ROMITO, Patrizia. Trabalho, maternidade e saúde das mulheres: algumas notas metodológicas. In: OLIVEIRA, Eleonora Menicucci de; SCAVONE, Lucila. (org). Trabalho, Saúde e Gênero na era da globalização. Goiânia: AB Editora, 1997. p. 15-27.

${ }^{484}$ FERNANDES, Maria das Graças de Melo. O corpo e a construção das desigualdades de gênero pela ciência. Revista de Saúde Pública, Rio de Janeiro, v. 19, n. 4, p. 1051-1065, 2009.

${ }^{485}$ ROHDEN, Fabíola. Uma ciência da diferença: sexo e gênero na medicina da mulher. Rio de Janeiro: Editora FIOCRUZ, 2001. p. 54.

${ }^{486}$ Ibid., p. 55.

${ }^{487}$ NUNES, Sílvia Alexim. Histeria e psiquiatria no Brasil da Primeira República. História, Ciências, Saúde - Manguinhos, Rio de Janeiro, v. 17, supl. 2, p. 373-389, dez.2010. p. 374.
} 
sua fraqueza nervosa, tendo servido como parâmetro negativo para delimitação dos critérios médicos que definiam uma boa esposa e boa mãe. ${ }^{488}$

Tanto a histeria, quanto outras perturbações mentais associadas aos órgãos reprodutivos femininos, como a loucura puerperal, também foram descritos na produção médica brasileira do século XIX. Inclusive, a menstruação era interpretada como uma das mais claras expressões do caráter instável da constituição física e mental das mulheres. Não só nas consideradas "fases críticas" - determinadas pelo aparecimento da menstruação na puberdade e pelo seu fim na menopausa -, mas em todo o período de sua recorrência, entendia-se que a mulheres estariam sujeitas a perturbações. Assim, era "quase como se a condição de mulher, por sua própria natureza, beirasse a patologia". ${ }^{489}$ Segundo Fabíola Rohden,

(...) é com base na interpretação dos médicos sobre fenômenos como a menstruação - que os definem como fases de "intensa atividade genésica" ou de manifestação do desejo sexual - e também na patologização dessas fases, que se compreende a instabilidade observada nas mulheres. (...) É possível depreender dessas afirmações que não era incomum na época suspeitar-se da palavra e das atitudes de uma mulher em função de perturbações mentais quase que permanentes ligadas ao funcionamento do seu organismo. Um depoimento poderia perder seu valor jurídico e mesmo um crime poderia ser inocentado devido a essa suposta falta de responsabilidade das mulheres pelos seus atos. Talvez essa relativização do arbítrio feminino estivesse relacionada não só com a necessidade de tutela sugerida pelos médicos, mas também com a desqualificação da vontade e da razão femininas. Transformando a mulher em uma louca em potencial, que pode perder a razão em uma série de momentos, é possível desqualificar alguns de seus atos. A prática da masturbação, o adultério e mesmo o infanticídio são alguns comportamento muitas vezes explicados pela loucura. ${ }^{490}$

A relação entre a menstruação e os desequilíbrios mentais nas mulheres é exemplificada por Elisabeth Meloni Vieira, que cita o discurso médico da época no sentido de que mulher menstruada não seria senhora de si mesma, nem seria equilibrada, devendo ser afastada dos negócios públicos neste "estado psíquico". Segundo a autora, "devido ao quadro clínico que as mulheres apresentam durante o

\footnotetext{
${ }^{488}$ ROHDEN, Fabíola. Uma ciência da diferença: sexo e gênero na medicina da mulher. Rio de Janeiro: Editora FIOCRUZ, 2001. p.83.

${ }^{489}$ Ibid., p. 141.

${ }^{490}$ Ibid., p. 144-145.
} 
período menstrual, vários fisiologistas da época afirmavam que a menstruação não é um estado fisiológico, mas uma moléstia fisiológica". 491

No começo do século XX, o ovário foi convertido no órgão que não só capacitaria as mulheres para a função reprodutiva, mas que também condensaria a feminilidade. A apreciação da saúde das mulheres e de sua própria identidade passa a ter como referência o bom funcionamento de seus ovários. Reafirma-se, assim, a conexão entre comportamento feminino e órgãos reprodutivos e, mais especificamente, entre perturbações mentais e problemas com os ovários. Inverte-se apenas a ideia de que a patologia seria decorrente do excesso relativo à sexualidade feminina, passando-se a destacar a imagem da falta ou carência de feminilidade, o que decorreria da "insuficiência ovariana". 492

Nesse momento, colocam-se em evidência os problemas hormonais das mulheres: os hormônios pareciam ser as substâncias capazes de desenvolver a feminilidade esperadas das mulheres, especialmente daquelas que não correspondiam às expectativas sociais. Dessa maneira, se o padrão de comportamento sexual, social ou estético "não se coadunava com o modelo de gênero esperado, a administração dos hormônios - as verdadeiras substâncias da feminilidade - poderia reconduzir as mulheres ao seu devido lugar". 493

Observamos, assim, que a relação que se estabeleceu entre genitalidade e psicologia femininas fundamentou o estigma de que as mulheres são seres sempre à beira da loucura, loucura que teria alicerces orgânicos, aparentemente incontestáveis. ${ }^{494}$ Exemplo dessa mentalidade é o caso relatado por Cordelia Fine sobre um professor da Harvard Medical College, Richard Cabot, que em 1915 discursou para a turma de formandas do Woman's College of Philadelphia. Segundo jornais da época, Cabot teria dito às jovens que médicas eram "temperamental e fisicamente inadequadas para as áreas da Medicina que exigem grande perícia e esforço", utilizando como respaldo os argumentos do neurologista Charles L. Dana, segundo o qual as mulheres estariam mais sujeitas a serem acometidas por psicoses que os homens. Na época, este neurologista havia prognosticado que "se as mulheres alcançarem o ideal feminista e viverem como

\footnotetext{
${ }^{491}$ VIEIRA, Elisabeth Meloni. A medicalização do corpo feminino. Rio de Janeiro: Editora FIOCRUZ, 2002. p. 43.

${ }^{492}$ ROHDEN, Fabíola. Uma ciência da diferença: sexo e gênero na medicina da mulher. Rio de Janeiro: Editora FIOCRUZ, 2001. p. 165-166.

${ }^{493}$ Ibid., p. 165-166.

${ }^{494}$ VIEIRA, Elisabeth Meloni, op. cit., p. 71.
} 
os homens vivem, elas correrão o risco de ter mais $25 \%$ de insanidade do que elas têm hoje". 495

Apesar de a sociedade e a Medicina terem avançado do início do século $\mathrm{XX}$ até hoje, interessante notar que o estereótipo de que as mulheres são mais instáveis emocionalmente e a vinculação dessa instabilidade ao ciclo menstrual e aos hormônios ainda são muito comuns. De acordo com Henrietta Moore, é extremamente difícil desmascarar argumentos sobre o modo como a biologia supostamente determina o comportamento humano, porque "eles implicam que a relação entre biologia e comportamento social pode ser compreendida como uma relação simples de causa e efeito". Entretanto, segundo a autora, a pesquisa médica contemporânea, profissional e responsável, rejeita esse ponto de vista, uma vez que "a biologia é um componente dinâmico de nossa existência e não um determinante de mão única". 496

Nesse aspecto, merecem menção os estudos de Anne Fausto-Sterling, buscando demonstrar que hormônios não têm sexo e que, portanto, não são determinantes do comportamento de homens ou mulheres. Ela questiona os motivos do fascínio inabalável pelas propriedades do estrogênio e da testosterona enquanto "hormônios sexuais", se na verdade ambos afetam o corpo como um todo e não são específicos de cada sexo. O crescimento adequado do cérebro, pulmões, ossos, vasos sanguíneos, intestino e fígado, por exemplo, depende do estrogênio. ${ }^{497}$

Segundo a autora, somente por meio da análise de como se dão as intersecções entre diversas esferas sociais (médicos, companhias farmacêuticas, biólogos, médicos, sexólogos, feministas, eugenistas, especialistas em controle de natalidade, ativistas etc.) é possível vislumbrar os meios pelos quais certas moléculas se tornaram parte do nosso sistema de gênero, ou seja, "how gender became chemical" 498 De acordo com ela, mesmo sem essa intenção, muitos trabalhos científicos sobre a biologia hormonal estavam profundamente ligados à política de gênero, o que só se

\footnotetext{
${ }^{495}$ FINE, Cordelia. Homens não são de Marte, mulheres não são de Vênus: como a nossa mente, a sociedade e o neurossexismo criam a diferença entre os sexos. São Paulo: Cultrix, 2012. p. 292-293.

${ }^{496}$ MOORE, Henrietta. Understanding Sex and gender. In INGOLD, Tim (org.). Companion Encyclopedia of Antropology. London: Routledge, 1997. (Tradução de Júlio Assis Simões para uso didático). p. 1.

${ }^{497}$ FAUSTO-STERLING, Anne. Sexing the body: Gender politics and the construction of sexuality. New York: Basic Books, 2000. p. 147.

${ }^{498}$ Ibid., p. 148.
} 
torna visível quando compreendemos "social" e "científico" como sistema indissociável de ideias e práticas. ${ }^{499}$

Anne Fausto-Sterling afirma que, desde o final do século XIX, as mulheres foram cientificamente descritas como disformes, inferiores, em cujos corpos "falta alguma coisa", passando da hipótese de que "faltava calor" em seu desenvolvimento, que permitiria a exteriorização do pênis, e chegando à "falta de testículos e dos hormônios por ele produzidos". O mesmo esquema lógico estaria por trás das teorias que lançam mão da influência dos "hormônios sexuais" para explicar, por exemplo, a hetero ou bissexualidade. Assim, a autora conclui que

(...) humans are learners, and proudly so. We are, arguably, the most mentally complex of all animals (no offense meant to the great apes, who might argue with us if they could speak). It seems ironic, therefore, that our most prominent and influential accounts of the development of sexual behaviors in advanced mammals omit learning and experience. ${ }^{500}$

Hoje em dia, muito dos mitos criados em torno dos "hormônios sexuais" ainda são utilizados como argumentos de autoridade, já que supostamente científicos, para diferenciar os comportamentos feminino e masculino. ${ }^{501}$ Concepções sobre a instabilidade psicológica e emocional das mulheres persistem baseadas nas mesmas ideias sexistas, envolvendo especialmente "alterações hormonais por que passa o

${ }^{499}$ FAUSTO-STERLING, Anne. Sexing the body: Gender politics and the construction of sexuality. New York: Basic Books, 2000. p. 149.

${ }^{500}$ Ibid., p. 232.

${ }^{501}$ Nesse sentido, o autor de livros campeões de venda, John Gray, em seu "Por que Vênus e Marte colidem" - continuação do "Homens são de Marte e Mulheres são de Vênus" - usa os hormônios como argumentos de autoridade para fundamentar sua tese sobre as diferenças entre os sexos, tudo sem nenhuma referência, nota explicativa ou demonstração em pesquisa empírica: "Men generally are very happy to do all the things that are not nurturing. Basically, they are happy to fix things that break. 'Fixing' is testosterone-producing, while nurturing is oxytocin-producing. Other testosterone-producing domestic activities are setting up, handling, and running the various gadgets in the house, driving (...), keeping the garage and yard up, emptying the trash and other dirty jobs, carrying heavy boxes, bringing in shopping bags (...), handling leaks, emergencies, and disasters, and checking outside when there is danger. It is important that women recognize that these are the kinds of things she can always ask him to do; they will make him feel more bonded to her when he succeeds in doing them, and she appreciates his help. When a woman wants a man to share in the domestic responsibilities, it can happen, but it won't look the way a woman might do it. Women instinctively want to share the process and make decisions together, but men will have a much greater need for the space to do it their way and in their time. (...) Doing something on your own produces testosterone; doing things together produces oxytocin. "I did it" produces testosterone, while "We did it" produces oxytocin" (GRAY, John. Why Mars and Venus Collide: Improving Relationships by Understanding How Men and Women Cope Differently with Stress. London: Harper Collins, 2008. p. 123-125). Argumentos como esses demonstram a utilização dos "hormônios sexuais" para justificar, com aparente cientificidade, a divisão sexual do trabalho, naturalizando as relações de gênero. 
organismo feminino no decorrer do ciclo menstrual e atinge, geralmente, o seu máximo no período pré-menstrual". 502

Sobre a chamada tensão pré-menstrual, ou TPM, cabe salientar que ela também é parte da construção da imagem social da irracionalidade feminina, atribuída à questão hormonal. Considerada uma realidade indiscutível por nossa sociedade, é fundamental frisar que esta hipotética perturbação pode e deve ser relativizada, uma vez que "nem todas as sociedades reconhecem a TPM e que mulheres que passam a viver em sociedades onde ela existe possam apresentar os sintomas", em um processo conhecido pela Antropologia como culture bound syndromes. ${ }^{503}$

Assim, com a influência hormonal colocada em dúvida, abrimos caminho para pesquisas como a de Cássia Maria Carloto, que apontam como fatores que mais provocam estresse nas mulheres: desgaste físico excessivo, devido à carga de trabalho assalariado e doméstico não remunerado, somado à falta de descanso e à má alimentação; assédio sexual no ambiente de trabalho; agressões contra as especificidades do corpo feminino, especialmente na questão do controle de idas e tempo de permanência no banheiro, somada à exposição a produtos químicos e a agentes biológicos; interrupção da amamentação e falta de berçário e creche para deixarem seus filhos e filhas; trabalho repetitivo e isolamento. ${ }^{504}$

Portanto, apesar de a construção histórica da instabilidade feminina ainda ser sancionada como verdade pela "incontestabilidade da ciência, inexoravelmente natural, no espaço estreito de uma normalidade reprodutora", ${ }^{505}$ uma análise crítica e responsável baseada nas relações de gênero permite verificar que muitos dos problemas emocionais das mulheres decorrem dos papéis e responsabilidades atribuídos a elas, independente do útero, da menstruação ou dos hormônios.

\footnotetext{
502 NOGUEIRA, Diogo Pupo. Trabalho de Mulheres. Revista Brasileira de Saúde Ocupacional, Ministério do Trabalho / Fundacentro, v. 38, n. 10, abr/mai/jun.1982. p. 12-16

${ }^{503}$ SELL, Mariléia; OSTERMANN, Ana Cristina. Analise de categorias de pertença (ACP) em estudos de linguagem e gênero: a (des)construção discursiva do homogêneo masculino. Alfa, São Paulo, v. 53, n. 1, p. 11-34, jan.2009. p. 15.

${ }^{504}$ CARLOTO, Cássia Maria. In: BARRETO, Margarida; CARLOTO, Cássia Maria; COSTA, Maria Luiza da. Saúde das Trabalhadoras. São Paulo: SOF Sempreviva Organização Feminista, 1998. A saúde das trabalhadoras. p. 9-37. p. 21-22.

${ }^{505}$ VIEIRA, Elisabeth Meloni. A medicalização do corpo feminino. Rio de Janeiro: Editora FIOCRUZ, 2002. p. 71.
} 


\subsection{Transtornos mentais e relações de gênero}

Estudos epidemiológicos têm constatado diferenças significativas entre homens e mulheres na prevalência, perfil de sintomas e fatores de risco para transtornos mentais. Ao mesmo tempo, a pesquisa sobre as diferenças observadas está progredindo "para além das explanações hormonais, em direção a investigações mais sofisticadas que sugerem fatores de neurodesenvolvimento, neurofisiológicos e ambientais atuando tanto nos homens quanto nas mulheres". 506

Desse modo, assistimos a uma alteração do modo como Medicina e Psicologia compreendem a diferente incidência de problemas psíquicos entre os gêneros. Podemos citar como exemplo a maior ocorrência de depressão em mulheres, que chega ao triplo de casos em relação aos homens: ao invés de explicações biologizantes, de que essa predominância seria causada pelos "hormônios femininos", algumas pesquisas estão buscando uma interpretação histórica e social do fenômeno, "preocupada com as condições materiais e existenciais que favorecem o sofrimento psíquico e seu agravamento", de forma a demonstrar "quanto os fatores de risco relacionados à depressão são engendrados e sociais". 507

Segundo Katharine A. Phillips e Michael B. First, o gênero pode virtualmente afetar todos os aspectos da psicopatologia, no que se inclui a prevalência de transtornos mentais, o modo como os sintomas se expressam, o curso da doença, a busca de tratamento e, até mesmo, se a pessoa apresenta melhora com o tratamento. Isso significa, voltando ao exemplo da depressão, que apesar de as mulheres terem mais chances de ficarem deprimidas que os homens, elas respondem melhor à medicação. De modo semelhante,

(...) mulheres com transtorno bipolar têm mais chance de ter um padrão de ciclagem rápida. As mulheres apresentam mais chance de ser expostas a algumas "toxinas" ambientais, que podem influenciar o desenvolvimento de doença (por exemplo, abuso sexual), ao passo que os homens têm mais chance de ser expostos a outras toxinas (por exemplo, abuso físico). De maneira crescente, a pesquisa está elucidando diferenças neurobiológicas intrigantes entre homens e

\footnotetext{
${ }^{506}$ NARROW, William E. Prefácio. In: NARROW, William E.; FIRST, Michael B.; SIROVATKA, Paul J.; REGIER, Darrel A. (org.). Gênero e Idade: Considerações no diagnóstico psiquiátrico. São Paulo: Roca, 2008. p. VII-X. p. IX.

${ }^{507}$ ZANELLO, Valeska; SILVA, René Marc Costa e. Saúde mental, gênero e violência estrutural. Revista Bioética, Brasília, v. 20, n. 2, p. 267-279, 2012. p. 268-269.
} 
mulheres, que provavelmente interajam de maneira complexa com fatores socioculturais para produzir a doença mental..$^{508}$

O fato de que "homens e mulheres apresentam diferentes graus de cargas demográficas, como pobreza, desemprego e responsabilidades", faz com que tenham "riscos diferentes de experimentar estressores de vida frequentes" e que reajam diversamente a esses estressores. No caso das mulheres, isso significa que as maiores taxas de depressão podem estar associadas ao dever de cuidado dos filhos e filhas, menores níveis de emprego e renda. Ao mesmo tempo, porém, o impacto psicológico do desemprego é maior sobre os homens, por carregarem o rótulo de provedores do lar. ${ }^{509}$

Além da depressão, a literatura médica assinala a predominância feminina em transtorno distímico e transtornos de ansiedade, ao passo que aponta a predominância masculina em transtornos por uso de substâncias e transtorno de personalidade antissocial. Katherine L. Wisner e Regina Dolan-Sewell identificam o gênero entre os fatores que podem responder por esses quadros, devido às diferenças de homens e mulheres "na recordação, nos autorelatos, na resposta à sintomatologia, nos efeitos de entrevista, na busca pelo tratamento e nos vieses sexuais dos critérios diagnósticos". ${ }^{510}$ As autoras explicam que

(...) fatores ambientais, como ocupação, comportamento, estilo de vida, hobbies, estado reprodutivo ou atividade física são afetados pelo gênero e exercem um impacto importante sobre o estado de saúde. As exposições das mulheres tendem a diferir daquelas dos homens nos ambientes domésticos e laboral, durante a gestação, na criação dos filhos e no cuidado com idosos. As exposições ocorrem ao longo do ciclo de vida, são cumulativas e, provavelmente, afetam a saúde. Conforme exposições agudas com efeitos marcados são eliminadas, as exposições crônicas e de baixo grau tornam-se mais importantes na influência sobre os desfechos de saúde. Um exemplo que tem recebido atenção da pesquisa psiquiátrica é o estresse crônico, suas sequelas fisiológicas e a associação do estresse com o desenvolvimento de transtornos do humor e outros transtornos psiquiátricos. A suscetibilidade diferencial sexo-específica a fatores ambientais deve

\footnotetext{
${ }^{508}$ PHILLIPS, Katharine A.; FIRST, Michael B. Introdução. In: NARROW, William E.; FIRST, Michael B.; SIROVATKA, Paul J.; REGIER, Darrel A. (org.). Gênero e Idade: Considerações no diagnóstico psiquiátrico. São Paulo: Roca, 2008. p. 2-5. p. 2.

${ }^{509}$ SHEAR, Katherine; HALMI, Katherine A.; WIDIGER, Thomas A.; BOYCE, Cheryl. Gênero e fatores socioculturais. In: NARROW, William E.; FIRST, Michael B.; SIROVATKA, Paul J.; REGIER, Darrel A. (org.). Gênero e Idade: Considerações no diagnóstico psiquiátrico. São Paulo: Roca, 2008. p. 63-77. p. 65 .

${ }^{510}$ GRANT, Bridget F.; WEISSMAN, Myrna M. Gênero e prevalência de transtornos psiquiátricos. . In: NARROW, William E.; FIRST, Michael B.; SIROVATKA, Paul J.; REGIER, Darrel A. (org.). Gênero e Idade: Considerações no diagnóstico psiquiátrico. São Paulo: Roca, 2008. p. 28-44. p. 39.
} 
também ser incluída nos modelos etiológicos dos transtornos psiquiátricos. ${ }^{511}$

Observa-se, assim, que questões centrais acerca das causas, natureza e sintomas das doenças mentais não podem ser respondidas sem se considerar o papel do gênero na doença mental ao longo do ciclo de vida. ${ }^{512}$ Portanto, fica patente que as relações de gênero, o ambiente e outros fatores socioculturais contribuem para as diferenças na saúde mental de homens e mulheres.

\subsection{Sofrimento psíquico das mulheres no trabalho}

Os transtornos mentais relacionados ao trabalho também são influenciados pelas relações de gênero. As mulheres normalmente experimentam uma receptividade especial ao sofrimento psíquico por conta da "responsabilidade familiar, pelo assédio no mundo do trabalho e pela insegurança no trabalho decorrente da dupla e ou extensiva jornada de trabalho - na casa e fora da casa", sendo que esses condicionantes de gênero "podem incidir fortemente sobre a saúde, chegando a constituir causa de deterioração em si". 513

No Brasil, mesmo com uma elevada subnotificação, as estatísticas do INSS mostram o aumento da incidência de transtornos mentais relacionados ao trabalho, tendo superado 12 mil registros em 2013. ${ }^{514}$ Além das doenças mentais, o aumento do estresse ocupacional também está associado à ocorrência de doenças como as LER/DORT, problemas cardíacos e do sistema digestivo, afora extremos que levam da depressão ao suicídio. ${ }^{515}$

Entre os fatores desencadeantes do sofrimento psíquico no trabalho, ou riscos psicossociais, estão:

\footnotetext{
${ }^{511}$ WISNER, Katherine L.; DOLAN-SEWELL, Regina. Por que o gênero importa? In: NARROW, William E.; FIRST, Michael B.; SIROVATKA, Paul J.; REGIER, Darrel A. (org.). Gênero e Idade: Considerações no diagnóstico psiquiátrico. São Paulo: Roca, 2008. p. 6-17. p. 7.

512 Ibid., p. 15.

${ }^{513}$ OLIVEIRA, Eleonora Menicucci de; BARRETO, Margarida. Engendrando gênero na compreensão das lesões por esforços repetitivos. Saúde e Sociedade [online], v. 6, n. 1, p. 77-99, 1997. p. 82-83.

${ }^{514}$ SELIGMANN-SILVA, Edith. Psicopatologia e saúde mental no trabalho. In: MENDES, René (org.). Patologia do Trabalho. $3^{\text {a }}$ ed. São Paulo: Atheneu, 2013. p. 1051-1114. p. 1054.

515 ORGANIZAÇÃO INTERNACIONAL DO TRABALHO. A prevenção das doenças profissionais: relatório para o Dia Mundial da Segurança e Saúde no Trabalho. Genebra: OIT, 2013. p. 5.
} 
a) exigencias psicológicas del trabajo: tecnoestrés y estrés debido a factores como el volumen de trabajo y relación cantidad/tiempo disponible o la insuficiencia de tiempo para acabar el trabajo, ritmo elevado de trabajo; falta de control y disposición sobre el trabajo y sobre el contenido de las tareas; b) factores sociales: relación con los compañeros, superiores y terceros: acoso psicológico y acoso sexual $o$ intimidación y violencia (psicológica), y discriminación en el trabajo; c) expectativas frente al trabajo y respuestas de éste: estrés, ansiedad. (...); d) precariedad laboral (tanto por la falta de estabilidad o contratación temporal por periodos breves y no consolidables o inciertos, como por las condiciones de trabajo contratadas y no disponibles por el trabajador, la modificación de dichas condiciones, el temor a la pérdida del empleo en todo caso y en particular en caso de formular reclamaciones de derechos.); y e) la doble carga de las mujeres trabajadoras (trabajo-vida familiar). ${ }^{516}$

Nesse sentido, pesquisas europeias sobre os riscos psicossociais afirmam que as mulheres - que em maior proporção executam tarefas monótonas, recebem salários inferiores etc. - têm menos controle sobre seu trabalho e menos expectativas de promoção, além de sofrerem assédio moral e sexual em maior grau que os homens, o que prejudica sua saúde mental. ${ }^{517}$

A influência das questões de gênero na maneira como o trabalho é vivenciado por cada sexo pode ser observada na forma como os transtornos mentais comuns de mulheres e o trabalho informal estão associados, o que não se verifica entre os homens. Segundo pesquisa de Ana Bernarda Ludermir, apesar da sobrecarga de trabalho, a inserção feminina no mercado formal associa-se a uma melhor saúde mental,

(...) pelo aumento do orçamento doméstico e pela proteção contra o isolamento, a monotonia e o baixo status que acompanham o papel de dona de casa na sociedade brasileira. Mas, enquanto $54 \%$ das trabalhadoras informais apresentavam ansiedade e depressão, apenas $19 \%$ dos homens sofriam com a informalidade. O emprego doméstico, uma extensão do papel tradicional de dona de casa, foi comum entre as mulheres e, nos homens, as ocupações de pedreiro e encanador, que exigem uma certa qualificação, foram as mais frequentes. Se para os homens o trabalho informal significa autonomia e a concretização do sonho de não ter patrão, para as mulheres, além da carga adicional de trabalho e da monotonia, representa uma oportunidade limitada e não reconhecida do uso de suas capacidades. ${ }^{518}$

\footnotetext{
516 VALLEJO, Pilar Rivas. Salud y género: perspectiva de género en la salud laboral. Revista Del Ministerio De Trabajo Y Asuntos Sociales, Madrid, n. Extra 74, p. 227-286, 2008. p. 248.

${ }^{517}$ ESPAÑA. Herramienta de apoyo $\mathrm{n}^{\mathbf{o}}$ 10: Salud y riesgos laborales con perspectiva de género. Madrid: Ministerio de Sanidad, Servicios Sociales e Igualdad, 2010. Disponível em: <http://www.igualdadenlaempresa.es/recursos/herramientas/home.htm>. Acesso em: 15.ago.2014. p. 7.

${ }^{518}$ LUDERMIR, Ana Bernarda. Inserção produtiva, trabalho e saúde mental. Cadernos de Saúde Pública, Rio de Janeiro, v. 16, n. 3, p. 647-659, jul./set. 2000. p. 656.
} 
Desse modo, fica evidente que a divisão sexual do trabalho e a opressão de gênero interferem diretamente nos transtornos psíquicos ocupacionais e, em especial, nos diferentes graus e formas de sofrimento de trabalhadoras e trabalhadores. Por conseguinte, os papéis sociais também interferem na saúde mental de mulheres e homens no trabalho, tal como veremos a seguir. ${ }^{519}$

\subsubsection{O papel social das mulheres como fator de sobrecarga e estresse}

A organização produtiva impõe seu ritmo não apenas pelos meios de pressão tradicionais sobre trabalhadores e trabalhadoras, como o desemprego e a precarização, mas também se utiliza de mecanismos ligados às relações de gênero. Dessa forma, o sistema capitalista encontra nas mulheres maior tolerância para imposição de regimes de trabalho "incompatíveis com a dignidade psicofísica do ser humano", impondo pressão sobre elas tanto no âmbito das relações de classe quanto das relações de gênero, em uma dupla opressão. ${ }^{520}$

Pesquisa de Arlie Russell Hochschild, no campo da sociologia das emoções, demonstrou não apenas os danos mentais sofridos pelas trabalhadoras de profissões tipicamente femininas, como as que envolvem o cuidado, por conta de práticas administrativas perversas, mas, ainda mais fortemente, os danos causados pela concorrência que se estabelece entre o local de trabalho e o lar, que disputam atenção e dedicação do trabalho afetivo exercido pelas mulheres. ${ }^{521}$

Ao tratar o estresse relacionado ao trabalho como uma questão central em saúde e segurança ocupacionais, a OIT enfatiza que apesar de homens e mulheres sofrerem desse mal, as razões não são as mesmas entre os sexos, "o que pode exigir diferentes respostas nos cuidados de saúde". A organização destaca que "as mulheres tendem a sofrer mais de stress e fadiga, devido aos seus múltiplos papéis no trabalho e na família". 522

\footnotetext{
${ }^{519}$ ZANELLO, Valeska; SILVA, René Marc Costa e. Saúde mental, gênero e violência estrutural. Revista Bioética, Brasília, v. 20, n. 2, p. 267-279, 2012. p. 268.

${ }^{520}$ BONCIANI, Mario. Normas Regulamentadoras e a questão de gênero no trabalho. In: INSTITUTO LATINOAMERICANO DE EDUCAÇÃO INTEGRAL. Um olhar de gênero na saúde e segurança no trabalho, ILEI, São Paulo, nov.2005. p. 24-25.

${ }^{521}$ HOCHSCHILD, Arlie Russell. Emotion Work, Feeling Rules, and Social Structure. American Journal of Sociology, v. 85, n. 3, p. 551-575, nov. 1979.

522 ORGANIZAÇÃO INTERNACIONAL DO TRABALHO. $O$ ABC dos direitos das mulheres trabalhadoras e da igualdade de género. 2 ed. Genebra: OIT, 2007. p. 176.
} 
Para melhor compreensão das formas como a divisão sexual do trabalho, que deixa com as mulheres trabalhadoras a maior parte das responsabilidades e tarefas domésticas, é central entender os mecanismos psicológicos que determinam a relação entre as esferas profissional e familiar. Entre tais mecanismos, identifica-se o processo de spillover, que, na definição de Marisa Matias e Anne Marie Fontaine, refere-se ao "transporte de emoções, atitudes, competências e comportamentos do nível profissional para a esfera familiar e vice-versa, acrescentando ainda que este pode ser positivo ou negativo". 523

Essa forma de abordar a relação trabalho-família na mente do ser humano sugere que a experiência de cada indivíduo em um desses domínios afeta a experiência do outro, em processo de mão dupla. Dessa maneira, entende-se que as vivências que caracterizam o trabalho estão intimamente ligadas às vivências familiares e que o contrário também é verdadeiro. Ademais, a relação entre as esferas profissional e familiar podem ser tanto negativas quanto positivas: no primeiro caso, sustentam a noção de conflito entre trabalho e família, evidenciando um conflito de papéis; já no segundo caso, evidenciam a valorização desses papéis. ${ }^{524}$

No que diz respeito ao conflito trabalho e família, este pode ser dar de três formas: conflito baseado na tensão, no comportamento e no tempo. O conflito baseado na tensão envolve "a pressão produzida no âmbito de um papel que afeta ou dificulta o cumprimento das exigências do outro", ou seja, está relacionado a pressões para produtividade e competitividade, pressões psicológicas ou conflitos interpessoais que podem aumentar a fadiga, irritar ou trazer apatia a ponto de afetar o desempenho do outro papel. Já o conflito baseado no comportamento "corresponde a padrões comportamentais específicos de um determinado papel, que podem colidir com as expectativas comportamentais de outro domínio". 525

Para os estudos sobre as mulheres, interessa particularmente o conflito baseado no tempo, demonstrando que os múltiplos papéis desempenhados pelo indivíduo competem em termos temporais. Nesse contexto, as trabalhadoras estão especialmente desfavorecidas, uma vez que "mais tempo de trabalho pago não se traduz

\footnotetext{
${ }^{523}$ MATIAS, Marisa; FONTAINE, Anne Marie. A Conciliação de Papéis Profissionais e Familiares: O Mecanismo Psicológico de Spillover. Psicologia: Teoria e Pesquisa [online], v. 28, n. 2, p. 235-243, abr./jun.2012. p. 235.

${ }^{524}$ Ibid., p. 236.

${ }^{525}$ Ibid., p. 237.
} 
em menos tempo de trabalho não pago, dado que a responsabilidade pelas tarefas familiares e domésticas ainda lhes é atribuída". ${ }^{526}$ Interessante a ressalva das autoras de que, por exemplo,

(...) a participação do cônjuge na execução de tarefas familiares é determinante para a percepção de spillover positivo das mulheres, mas esta mesma execução de tarefas por parte dos homens agrava a sua própria percepção de spillover negativo (...). Deste modo, o papel do gênero deve também ser considerado nesta análise, uma vez que um mesmo indicador poderá ter um impacto distinto para homens e mulheres. ${ }^{527}$

Portanto, a abordagem do spillover serve para demonstrar a interdependência entre os papéis profissionais e os papéis exercidos no âmbito doméstico, permitindo compreender de maneira coerente as dificuldades associadas ao exercício simultâneo dessas múltiplas atribuições, além de permitir integrar as questões de gênero, que determina os papéis de homens e mulheres na família e no trabalho profissional, o que resulta em diferentes padrões de relação trabalho-família.

O equilíbrio nesse processo de influência trabalho-família e famíliatrabalho é necessário para a saúde mental de trabalhadores e trabalhadoras, caso contrário, a sobrecarga causada pela interação entre ambas as esferas pode causar sofrimento psíquico. Nessa lógica, podemos afirmar que as trabalhadoras estão mais expostas à sobrecarga, uma vez que são elas que culturalmente carregam o maior número de responsabilidades no âmbito familiar, que acumulam trabalhos geralmente desgastantes, mal remunerados e de baixo reconhecimento social. Somente o rompimento da divisão sexual do trabalho e a melhor distribuição e valorização dos papéis público e privado permitirão o equilíbrio e, portanto, uma convivência saudável entre esses dois espaços.

\footnotetext{
${ }^{526}$ MATIAS, Marisa; FONTAINE, Anne Marie. A Conciliação de Papéis Profissionais e Familiares: O Mecanismo Psicológico de Spillover. Psicologia: Teoria e Pesquisa [online], v. 28, n. 2, p. 235-243, abr./jun.2012. p. 237.

${ }^{527}$ Ibid., p. 240.
} 


\subsubsection{Violência psicológica, assédio moral e sexual no trabalho}

Além das diferentes cargas de responsabilidades familiares que recaem sobre homens e mulheres, as relações de gênero, por serem relações de poder, também servem de base para diferentes tipos de violência, tanto física quanto psicológica. $\mathrm{Na}$ esfera do trabalho, as mulheres são alvo majoritário do assédio e da violência psicológica, corporificações das relações de dominação de classe e gênero, provocando nas vítimas medo, angústia, humilhação e depressão, que comprometem a saúde das trabalhadoras e demonstram um ambiente laboral inseguro e hostil para as mulheres. ${ }^{528}$

O sofrimento psíquico também decorre do fato de as mulheres terem medo de denunciar as violências morais e sexuais, pois temem não apenas expor sua privacidade, mas também a possibilidade de serem desacreditadas e humilhadas e, por fim, perderem seus empregos. Esse tipo de violência que se estende da esfera privada à pública "é a mais forte e inominável violência de gênero", o que significa que "o exercício do poder em sua forma micro produz processos desconstrutivos mentais que, (...) ocultados e silenciados pela sociedade, atuam como elementos estruturantes da identidade feminina". 529

Nesse sentido, Doris Acevedo, Yajaira Biaggii e Glanés Borges afirmam que

(...) la violencia de género en el trabajo se origina en las relaciones laborales y en las relaciones sociales de sexo, y se manifiesta en acciones y situaciones de hostigamiento laboral y de acoso sexual. Se considera una manifestación de las relaciones de poder desiguales entre hombres y mujeres, en la cual las mujeres resultan más afectadas por su situación de discriminación y subordinación social, siendo los agresores mayoritariamente del sexo masculino. El problema guarda relación con los roles atribuidos a los hombres y a las mujeres en la vida social y económica que, a su vez, directa o indirectamente, afecta a la situación de las mujeres en el mercado del trabajo y en el ambiente laboral. ${ }^{530}$

Não é nosso objetivo no presente estudo repassar os conceitos jurídicos e elementos definidores do assédio moral, violência psicológica e assédio sexual no

\footnotetext{
${ }^{528}$ OLIVEIRA, Eleonora Menicucci de. A mulher, a sexualidade e o trabalho. São Paulo: CUT, 1999. p. 52.

${ }^{529}$ Ibid., p. 108.

${ }^{530}$ ACEVEDO, Doris; BIAGGII, Yajaira; BORGES, Glanés. Violencia de género en el trabajo: acoso sexual y hostigamiento laboral. Revista Venezolana de Estudios de la Mujer [online], v. 14, n. 32, p. 163182, 2009. p. 169.
} 
trabalho, ${ }^{531}$ de modo que manteremos nosso enfoque na questão da saúde psíquica das mulheres trabalhadoras. De toda forma, importante esclarecer alguns pontos conceituais que nos ajudem a delimitar o tema e a compreender como determinadas formas de violência no trabalho atingem as mulheres.

Iniciaremos nossa análise pelo assédio moral e pela violência psicológica, cujas noções se diferenciam especialmente devido à frequência. Desse modo, assédio moral no trabalho é definido como a conduta abusiva e intencional, que ocorre no ambiente de trabalho de forma frequente e repetida, cujo objetivo é constranger, humilhar e desqualificar e arrasar psicologicamente uma pessoa, "degradando as suas condições de trabalho, atingindo a sua dignidade e colocando em risco a sua integridade pessoal e profissional". ${ }^{532} \mathrm{Um}$ pouco diferente, a violência psicológica é entendida como "qualquer incidente ou evento, no qual um homem ou mulher torna-se alvo de atos injustos e ilícitos", podendo ser um ato isolado que explicite agressão verbal, ameaça, constrangimento, ofensa, humilhação ou discriminação. ${ }^{533}$

Especialmente o assédio moral pode desencadear formas severas de estresse no trabalho, motivo pelo qual é considerado um importante risco psicossocial, que precisa ser considerado tanto quanto os demais riscos labor-ambientais. ${ }^{534}$ Do mesmo modo que as LER/DORT, abordadas no capítulo anterior, o assédio moral não decorre de atitudes individuais de pessoas "cruéis" ou com "perfil assediador", mas sim das formas de organização e administração do trabalho. ${ }^{535}$ Assim, sofrimento e constrangimento no trabalho é um fenômeno ligado às consequências do avanço tecnológico, das exigências de qualidade, da intensificação do ritmo de trabalho e da

\footnotetext{
${ }^{531}$ Para aprofundamento sobre o tema na doutrina brasileira, ver: BARRETO, Margarida. Violência, Saúde e Trabalho (uma jornada de humilhações). São Paulo: EDUC/FAPESP, 2003. THOME, Candy Florencio. $O$ assédio moral nas relações de emprego. São Paulo: LTr, 2008. NASCIMENTO, Sonia Mascaro. Assédio moral. São Paulo: Saraiva, 2011.

${ }^{532}$ FREITAS, Maria Ester de; HELOANI, Roberto; BARRETO, Margarida. Assédio moral no trabalho. São Paulo: Cengage Learning, 2009. p. 52

${ }^{533}$ Ibid., p. 57.

${ }^{534}$ GLINA, Débora Miriam Raab; SOBOLL, Lis Andreia. Intervenções em assédio moral no trabalho: uma revisão da literatura. Revista brasileira de saúde ocupacional, São Paulo, v. 37, n. 126, p. 269-283, 2012. p. 271.

${ }^{535}$ BARRETO, Margarida; HELOANI, Roberto. Assédio laboral e as questões contemporâneas à saúde do trabalhador. LOURENÇO, Edvânia Ângela De Souza; NAVARRO, Vera Lucia (orgs.). O avesso do trabalho III: saúde do trabalhador e questões contemporâneas. São Paulo: Outras expressões, 2013. p. 107- 141. p. 119.
} 
precarização das relações de trabalho, tendo como consequência a "criação de uma subjetividade, que já nasce precarizada". 536

Nesse sentido, Margarida Barreto e Roberto Heloani afirmam que não há "limite de tolerância" em relação à violência psíquica no trabalho, uma vez que

(...) todos os trabalhadores e trabalhadoras submetidos ao parcelamento das tarefas associadas a grande quantidade de informação e exigências durante o processo produtivo e que, ademais, são constrangidos e humilhados, vivem uma vida contraída. Passam a viver de pensamentos repetitivos transpassados por sentimentos tristes. Estes, ao longo do tempo, se caracterizam por microtraumas que obstruem as conexões psíquicas, o que favorece $o$ desencadeamento dos transtornos psíquicos. Portanto, quando as humilhações se repetem por longo tempo, causam sequelas psíquicas. São aspectos resultantes do processo de trabalho provenientes de fatores pontuais e que se articulam com a organização do trabalho e administração que mantém, sustenta e prima pela estrutura hierárquica organizacional assimétrica, autoritária e, muitas vezes, despótica, instituindo o terreno propício para o assédio laboral na contemporaneidade. ${ }^{537}$

Marie-France Hirigoyen define assédio moral no trabalho como "qualquer conduta abusiva", manifestada por comportamentos, palavras, atos ou gestos, "que possa trazer dano à personalidade, à dignidade ou à integridade física ou psíquica de uma pessoa, pôr em perigo seu emprego ou degradar o ambiente de trabalho". 538 Interessante notar que apesar de Hirigoyen não afirmar categoricamente que as mulheres são as maiores vítimas do assédio moral, a maioria dos exemplos em seu livro de entrevistas com pessoas assediadas é de mulheres, como Cathy (p. 70), Cecilia (p. 71), Denise (p. 72), Muriel (p. 74), Eva (p. 83). Miriam (p. 88) e Lucia (p.91).

De acordo com Ângelo Soares, embora na literatura ainda não haja consenso a respeito do efeito da variável gênero sobre o assédio moral, "quando se tenta responder à questão de quem é mais assediado, homens ou mulheres, vários autores identificam a existência de uma divisão sexual no assédio moral". Segundo o autor, um dos aspectos que demonstram essa divisão é a frequência dos gestos que compõem o assédio, que é mais elevada para as trabalhadoras: enquanto a maioria dos homens

\footnotetext{
${ }^{536}$ BARRETO, Margarida; HELOANI, Roberto. Assédio laboral e as questões contemporâneas à saúde do trabalhador. LOURENÇO, Edvânia Ângela De Souza; NAVARRO, Vera Lucia (orgs.). O avesso do trabalho III: saúde do trabalhador e questões contemporâneas. São Paulo: Outras expressões, 2013. p. 107- 141. p. 119-120.

${ }^{537}$ Ibid., p. 120-121.

${ }^{538}$ HIRIGOYEN, Marie-France. Assédio moral: a violência perversa no cotidiano. Rio de Janeiro: Bertrand Brasil, 2002. p. 65.
} 
declara ser assediado uma vez por semana, as mulheres afirmam serem assediadas cotidianamente no local de trabalho. ${ }^{539}$

No Brasil, Margarida Barreto foi pioneira no estudo do assédio moral e da violência psicológica no trabalho, em pesquisa realizada com 2.072 trabalhadores e trabalhadoras do ramo químico e farmacêutico de São Paulo, entre 1996 e $2000 .{ }^{540}$ Situando a humilhação e o assédio no campo das relações de poder e compreendendo-os como fatores relevantes na degradação do ambiente laboral, que passa a ser um espaço de terror psicológico e de sofrimento, tanto individual quanto coletivo ${ }^{541}$, a autora relata que

(...) a análise dos dados encontrados nas conversas clínicas prolongadas evidenciou que a humilhação constitui um indicador importante na avaliação das condições de trabalho e saúde de trabalhadores e trabalhadoras, revelando uma das formas mais poderosas de violência sutil nas relações organizacionais e na sociedade, mais frequente com as mulheres e os adoecidos. (...) Em relação às mulheres $(56,8 \%)$, a análise das falas revelou maior frequência de situações de humilhações quando comparadas aos homens $(43,2 \%)$, evidenciando controle maior da força de trabalho feminina. ${ }^{542}$

São inúmeras as ilustrações dos modos de submeter e humilhar as mulheres trabalhadoras, dentre as quais o controle de idas ao banheiro e a fiscalização de bolsas na saída da empresa, a manipulação de presentes que se transformam em roubo e fundamentam dispensas por justa-causa, o que revela que a empresa não é apenas espaço de exploração do corpo e expropriação da saúde, mas é também "lócus disciplinador e reprodutor dos sistemas de valores sociais". 543

De maneira complementar, Candy Florencio Thome afirma que as mulheres são alvo prioritário em situações de assédio moral porque o medo de perderem seu emprego é maior, uma vez que as trabalhadoras são geralmente as primeiras da lista em situações como corte de empregos. O medo decorre não apenas da possibilidade de perda do salário, mas também do fato de que "o trabalho, por vezes, é o único espaço de liberdade e de socialização, configurando uma estratégia defensiva da opressão vivida

\footnotetext{
${ }^{539}$ SOARES, Ângelo; OLIVEIRA, Juliana Andrade. Assédio moral no trabalho. Revista brasileira de saúde ocupacional, São Paulo, v. 37, n. 126, p. 195-202, 2012. p. 196.

${ }^{540}$ BARRETO, Margarida. Violência, saúde e trabalho: uma jornada de humilhações. São Paulo: EDUC, 2013. p. 27.

${ }^{541}$ Ibid., p. 40.

${ }^{542}$ Ibid., p. 197-203.

${ }^{543}$ Ibid., p. 137.
} 
no ambiente familiar". Além disso, a autora frisa que muitas ofensas se mascaram com a ajuda dos estereótipos de gênero, como as alegações de que as mulheres seriam mais sensíveis a "brincadeiras" por conta de suas "variações hormonais". 544

Além do assédio moral e da violência psicológica, o sofrimento psíquico das trabalhadoras também decorre de ainda mais perversa forma de violência: o assédio sexual. Apesar de a doutrina juslaboralista brasileira dividir o assédio sexual em dois tipos, o assédio sexual por chantagem ou "quid pro quo" e o assédio sexual por intimidação ou ambiental, diferenciando-os como se neste segundo o poder exercido entre agressor e vítima fosse irrelevante ${ }^{545}$ - por não envolver ameaça ou chantagem, mas "apenas" incitações sexuais inoportunas, verbais ou físicas -, é preciso ressaltar que ambas as situações envolvem relação de poder, quando não o poder conferido pela hierarquia do trabalho, ainda assim a opressão de gênero.

Nesse sentido, a OIT considera todos os tipos de assédio sexual como forma de discriminação de gênero. Apesar de não existir tratado específico sobre o tema, a Comissão dos Especialistas em Aplicação de Convenções e Recomendações da OIT condenou oficialmente o assédio sexual com base na Convenção 111, sobre discriminação em matéria de emprego e ocupação. ${ }^{546}$ Do mesmo modo, as Conferências Internacionais do Trabalho de 1985 e 1991 adotaram resoluções em que o assédio sexual é inserido no contexto das condições laborais e meio ambiente de trabalho. ${ }^{547}$

Em âmbito internacional, além da OIT, a Recomendação Geral nº 19 da CEDAW, sobre a violência contra as mulheres dispõe que:

Article 11 - 17. Equality in employment can be seriously impaired when women are subjected to gender-specific violence, such as sexual harassment in the workplace. 18. Sexual harassment includes such unwelcome sexually determined behavior as physical contact and advances, sexually colored remarks, showing pornography and sexual demand, whether by words or actions. Such conduct can be humiliating and may constitute a health and safety problem; it is discriminatory when the woman has reasonable grounds to believe that her objection would disadvantage her in connection with her

\footnotetext{
544 THOME, Candy Florencio. O assédio moral nas relações de emprego. São Paulo: LTr, 2008. p. 106.

545 Como faz Rodolfo Pamplona Filho ao afirmar que no assédio ambiental o "elemento poder é irrelevante" (PAMPLONA FILHO, Rodolfo. Assédio sexual na relação de emprego. São Paulo: LTr, 2001. p. 47). Muito pelo contrário, as condutas intimidam justamente por envolverem relações de poder entre os sexos, que vão além da relação de emprego.

${ }^{546}$ Adotada pela OIT em 1958; ratificada pelo Brasil em 26.11.1965.

${ }^{547}$ ORGANIZAÇÃO INTERNACIONAL DO TRABALHO. El hostigamiento o acoso sexual. Genebra: OIT, 2013. p. 7. Disponível em: <http://www.ilo.org/sanjose/publicaciones/WCMS_227404/lang-es/index.htm>. Acesso em: 12.set.2014.
} 
employment, including recruitment or promotion, or when it creates a hostile working environment. ${ }^{548}$

Entendido como "um passo a mais na perseguição moral”, Marie-France Hirigoyen afirma que apesar de ter relação com ambos os sexos, a maior parte dos casos descritos, ou de queixas, é de mulheres agredidas por homens, majoritariamente seus superiores hierárquicos. Os comportamentos que configuram assédio sexual descritos em sua pesquisa são: o assédio de gênero, caracterizado por comentários ou comportamentos sexuais dirigidos a uma mulher por ela ser mulher; o comportamento sedutor; a chantagem sexual; a atenção sexual não desejada; a imposição e a ofensiva sexual. Segundo ela, o assédio sexual

(...) não se trata tanto de obter favores de natureza sexual quanto de afirmar o próprio poder, de considerar a mulher como seu objeto (sexual). Uma mulher assediada sexualmente é considerada por seu agressor como estando 'à disposição'. Ela deve aceitar e até se sentir lisonjeada, realçada, por ter sido 'escolhida'. $\mathrm{O}$ assediador não admite que a mulher visada possa dizer não. Aliás, se ela o faz, sofre em revide humilhações e agressões. Não é raro que o agressor diga que foi ela quem o provocou, que ela era permissiva ou que foi ela quem tomou a iniciativa". ${ }^{449}$

Essa relação é explicada por Cordelia Fine pelo que ela denomina sexismo benevolente e sexismo hostil, especialmente no ambiente de trabalho: a mulher que se atém a seus "papéis tradicionais" seria digna de desfrutar dos estereótipos de "mulher maravilhosa", digna do cavalheirismo cortês dos homens (sexismo benevolente); já as mulheres que fogem dos papéis tradicionais e buscam melhores posições e maior poder passam, então, a ser adversárias. "A discriminação hostil contra as mulheres no local de trabalho é praticada de uma maneira intencional e consciente. Ela pode envolver a 'segregação, a exclusão, comentários, o assédio e a agressão"”, 550

Segundo a autora, o extremo da conduta de hostilidade em relação às mulheres no local de trabalho é o assédio sexual. Ao relatar a análise feita em ações coletivas de assédio sexual nos Estados Unidos, concentradas em casos em que as mulheres tentavam ter acesso a alguns cargos mais altos da indústria automotiva e de

\footnotetext{
548 Disponível em: <http://www.un.org/womenwatch/daw/cedaw/recommendations/recomm.htm>. Acesso em: 15.ago.2014.

${ }^{549}$ HIRIGOYEN, Marie-France. Assédio moral: a violência perversa no cotidiano. Rio de Janeiro: Bertrand Brasil, 2002. p. 80-81.

${ }^{550}$ FINE, Cordelia. Homens não são de Marte, mulheres não são de Vênus: como a nossa mente, a sociedade e o neurossexismo criam a diferença entre os sexos. São Paulo: Cultrix, 2012. p. 102-103.
} 
mineração, descreve um padrão similar de assédio envolvendo apalpar, agarrar, usar linguagem sexual e pornográfica, colegas homens expondo seus órgãos sexuais e se masturbando na roupa das mulheres. Ela constata que

A mera vulgaridade do comportamento indica que esse tipo de comportamento de assédio não se originou do ímpeto erótico de ter mulheres por perto, mas, antes, que ele forneceu uma maneira de "criar um ambiente que comunicava uma hostilidade expressa com relação às mulheres" e "disciplinar as mulheres que tentavam se infiltrar em locais de trabalho anteriormente exclusivamente masculinos". 551

Em termos estatísticos, levantamento de 2011 da ONU revelou que entre 40 e 50\% das mulheres da União Europeia são vítimas de contato físico, insinuações verbais e outras formas de assédio sexual em seu local de trabalho, índice que na região Ásia-Pacífico é de 30 a $40 \% .{ }^{552}$ Números similares são encontrados nos Estados Unidos, onde $50 \%$ das mulheres declararam ter sofrido assédio sexual em algum momento de sua vida profissional. ${ }^{553}$

Apesar de as mulheres mais pobres serem mais vulneráveis ao assédio, uma vez que sofrem a opressão de gênero somada à opressão de classe e ao medo de ficarem sem emprego, é fato que a dominação masculina ocorre em todos os ambientes. Recente reportagem do jornal The New York Times, relatando o assédio sexual no meio acadêmico, divulgou uma pesquisa apresentada no Instituto de Tecnologia de Massachusetts, que entrevistara 512 pesquisadoras e pesquisadores. Os dados coletados revelaram que: mais da metade das mulheres afirmaram não serem levadas a sério por serem do sexo feminino; uma a cada três disse ter sofrido barreiras no progresso na carreira; metade disse ter sido "paquerada" ou ter ouvido comentários sexuais no meio acadêmico; uma em cada cinco sofreu contato físico indesejado. 554555

\footnotetext{
${ }^{551}$ FINE, Cordelia. Homens não são de Marte, mulheres não são de Vênus: como a nossa mente, a sociedade e o neurossexismo criam a diferença entre os sexos. São Paulo: Cultrix, 2012. p. 109.

${ }^{552}$ ORGANIZAÇÃO DAS NAÇÕES UNIDAS. Violence Against Women. New York: ONU, 2011. p. 2. Disponível em: <http://endviolence.un.org/pdf/pressmaterials/unite_the_situation_en.pdf〉. Acesso em: 12.set.014.

${ }^{553}$ MACRAE, Nancy. Women and work: a ten year retrospective. Work: A Journal of Prevention, Assessment and Rehabilitation [online], v. 24, p. 331-339, 2005. p. 334.

${ }^{554}$ ASCHWANDEN, Christie. Harassment in Science, Replicated. The New York Times, New York, 11.ago.2014. Disponível em: <http://www.nytimes.com/2014/08/12/science/harassment-in-sciencereplicated.html?_r=0>. Acesso em: 15.ago.2014.

${ }^{555} \mathrm{Na}$ própria Faculdade de Direito da Universidade de São Paulo, alunas e alunos convivem cotidianamente com o sexismo por parte de professores e professoras, seja por meio de atitudes discriminatórias, discursos preconceituosos ou mesmo assédio e comportamento invasivo. A denúncia
} 
Observa-se, assim, que no alicerce do assédio sexual prevalece opressão de gênero, em relação à opressão de classe e às relações de hierarquia no trabalho. ${ }^{556}$ Isso também é demostrado por estudos comparativos entre mulheres e homens no trabalho, uma vez que entre as assediadas encontram-se tanto trabalhadoras subalternas, quanto trabalhadoras especializadas e hierarquicamente superiores, vítimas de seus chefes e colegas de trabalho, ao passo que os homens são majoritariamente assediados por suas superiores. ${ }^{557}$

Dessa forma, a existência de uma maior proporção de mulheres que sofrem assédio sexual pode ser explicada pela junção entre os aspectos relacionados aos sistemas de dominação masculina arraigados em nossa cultura, que impõe aos homens a demonstração de sua virilidade por meio da sexualidade, e a divisão sexual do trabalho, que determina o "lugar" das mulheres tanto na esfera privada quanto em profissões femininas e posições hierárquicas inferiores. ${ }^{558}$

Em termos psíquicos, assédio moral, violência psicológica e assédio sexual convergem no sentido de que impregnam o meio ambiente do trabalho de medo, ${ }^{559}$ o que acarreta o sofrimento mental das trabalhadoras e trabalhadores. Enquanto expressões da opressão de gênero no trabalho, essas formas de violência afetam as condições de trabalho das vítimas, criando uma atmosfera insuportável, o que

contra esse tipo de comportamento foi feita em 2014, em ação do Coletivo Femista Dandara, que expôs as frases desrespeitosas e as "piadas" sexistas e homofóbicas do corpo docente em cartazes no pátio da faculdade, com o seguinte recado: "Docentes machistas não passarão". Dentre as frases ditas por professores, eram citadas "Casamento é um negócio jurídico: o homem entre com o dinheiro e a mulher com o serviço", "Homem não sabe por que bate, mas mulher sabe por que apanha" e "Assédio sexual é insignificante". Ver mais em: < http://m.estadao.com.br/noticias/saopaulo,alunos-apontam-preconceitona-usp, 1146483,0.htm>..

${ }^{556}$ Outra expressão patente da opressão de gênero no trabalho são as revistas íntimas - proibidas pela Lei $\mathrm{n}^{\circ}$. 9.799, de 1999, que incluiu o artigo 373-A na CLT - especialmente quando se trata da executada pelo empregador ou preposto sobre as empregadas mulheres, casos nos quais se observa a concretização da violência de gênero e de classe por meio da humilhação. Independente das discussões jurídicas a respeito da conotação do termo "íntimas" presente na lei e da extensão da proibição aos homens (extensão a qual somos favoráveis, já que a opressão de gênero manifesta-se de várias formas, não apenas em relação às mulheres), a perspectiva de gênero permite entender o sofrimento psíquico que as revistas íntimas podem causar em trabalhadoras e trabalhadores.

${ }^{557}$ ACEVEDO, Doris; BIAGGII, Yajaira y BORGES, Glanés.Violencia de género en el trabajo: acoso sexual y hostigamiento laboral. Revista Venezolana de Estudios de la Mujer [online], v. 14, n. 32, p. 163182, 2009. p.172.

${ }^{558}$ CAMPOS-SERNA, Javier; RONDA-PÉREZ, Elena; ARTAZCOZ, Lucía; BENAVIDES, Fernando. Desigualdades de género en salud laboral en España. Gaceta Sanitaria [online], vol. 26, n. 4, p. 343-351, 2012. p. 348.

559 ARAÚJO, Angela Maria Carneiro; OLIVEIRA, Eleonora Menicucci. Reestruturação produtiva e saúde no setor metalúrgico: a percepção das trabalhadoras. Sociedade e Estado, Brasília, v. 21, n. 1, p. 169-198, 2006. p. 191. 
gera baixo rendimento, absenteísmo e que chega inclusive à renúncia do trabalho. Ademais, suas consequências para a saúde de trabalhadoras e trabalhadores são devastadoras, fazendo desencadear uma série de problemas psicossomáticos nas vítimas, como transtornos de sono e digestivos, dores de cabeça, depressão, fadiga, e a continuidade no tempo pode causar grave deterioração na saúde mental. ${ }^{560}$

${ }^{560}$ ACEVEDO, Doris; BIAGGII, Yajaira y BORGES, Glanés. Violencia de género en el trabajo: acoso sexual y hostigamiento laboral. Revista Venezolana de Estudios de la Mujer [online], v. 14, n. 32, p. 163182, 2009. p. 179-180. 


\section{Conclusão}

A conquista definitiva do espaço das mulheres no mundo do trabalho criou a necessidade de novos enfoques sobre a relação saúde-trabalho, uma vez que os impactos dos riscos e fatores labor-ambientais são diferenciados e particulares para trabalhadoras e trabalhadores, permitindo que seja observada a interferência do gênero nos diferentes modos de adoecer. Diante dessa realidade, a presente dissertação buscou responder as seguintes perguntas: As mulheres precisam de tutela especial no Direito do Trabalho? A saúde e segurança das trabalhadoras estão realmente protegidas pela legislação? As atuais normas a esse respeito promovem igualdade ou discriminação?

Os panoramas históricos traçados ao longo deste estudo, que se preocupou em demonstrar concepção tanto das diferenças entre os sexos em si, até a construção do ideal de maternidade, da fragilidade feminina e da instabilidade das mulheres, permitiram constatar que muitas vezes a Medicina, a Biologia e outras ciências utilizam argumentos pretensamente científicos para justificar a desigualdade de gênero. Os estereótipos do feminino e masculino naturalizam os papéis de gênero em todos os aspectos da vida, o que gera impacto no reconhecimento do trabalho das mulheres - invisibiliza o trabalho doméstico não remunerado e desvaloriza o trabalho produtivo feminino -, bem como no reconhecimento das condições e riscos envolvidos nessas atividades.

Este cenário se reflete no Direito do Trabalho, que contraditoriamente faz a determinação constitucional da igualdade entre os sexos conviver com a tutela especial da CLT ao trabalho feminino, considerado carente de proteção tal como o trabalho de menores de 18 anos. Ora, se a diferença biológica central entre homens e mulheres está no aparelho reprodutor, um tratamento diferenciado do ordenamento jurídico apenas se justifica quando disser respeito à proteção da reprodução. No entanto, deve-se considerar que além da essencial proteção das trabalhadoras na gestação e lactação, que se reflete também na proteção do embrião em desenvolvimento e da criança recém-nascida, também é necessária a proteção da saúde reprodutiva dos homens trabalhadores, uma vez que muitas substâncias usadas no trabalho podem interferir em sua capacidade de ter filhos e filhas e, até mesmo, provocar a malformação de gametas. 
Significa dizer que restringir o acesso de mulheres a determinadas ocupações ou atividades, ou incluir requisitos para que elas exerçam trabalho em determinadas condições, quando não estiverem grávidas ou em período de lactação, é sim um gesto discriminatório. Se o trabalho for especificamente prejudicial à saúde humana, tanto as mulheres quanto os homens devem ser impedidos de executá-los, exigindo-se que o empregador elimine ou reduza os riscos; caso contrário, trabalhadoras e trabalhadores devem ter a oportunidade de exercê-lo, garantido o acesso a informações e treinamento, além de EPI realmente adequado ao indivíduo.

Dessa maneira, o regime jurídico do trabalho das mulheres precisa ser o mesmo que o dos homens, de modo que reste apenas a proteção à gravidez e ao aleitamento, ainda assim, respeitando-se a saúde reprodutiva dos homens e o direito dos pais trabalhadores de também cuidarem da prole. O enfoque do Direito para proteção labor-ambiental deve, assim, ser a criação de novas regras que tenham como finalidade mudanças na qualidade de vida das pessoas, bem como novas construções que ajudem a superar a naturalização dos atributos femininos e masculinos e sua instrumentalização pelo mundo do trabalho.

Conclui-se, respondendo às três perguntas lançadas, que uma legislação voltada à proteção das mulheres especificamente no cumprimento de seu papel social de mãe - e até pouco tempo atrás de esposa - tem efeitos potencialmente discriminatórios nas oportunidades de emprego e na continuidade ou promoção na carreira. Desse modo, o foco das normas de saúde e segurança no trabalho para as mulheres precisa ser da proteção baseada na variabilidade humana, o que permite uma igualização de direitos e a proteção a ambos os sexos. Afinal, o equilíbrio labor-ambiental só é possível quando o trabalho for saudável e seguro para cada trabalhadora ou trabalhador individualmente, independente do sexo e de outras características pessoais. Muda-se a perspectiva de proteção: não são as trabalhadoras que precisam ser excluídas de profissõ̃es com risco, mas sim o risco ocupacional é que precisa ser excluído do ambiente de trabalho, de modo a proteger a coletividade.

Isso demonstra a necessidade de revermos algumas normas relacionadas à proteção da saúde e segurança das mulheres, conforme pontuamos em cada capítulo, pois apesar de as últimas décadas terem sido importantes para a eliminação de dispositivos de tutela do trabalho feminino claramente sexistas, como o caso da proibição do trabalho noturno, restam ainda outras que, melhor fundamentadas pelos estereótipos de gênero arraigados na sociedade, ainda persistem vigentes. Entendemos 
que o papel fundamental do Direito do Trabalho é a garantia da integridade e da dignidade de todas as trabalhadoras e todos os trabalhadores, e que a superação das desigualdades é condição para a melhoria da saúde e qualidade de vida.

No entanto, precisamos ter consciência de que as normas de saúde e segurança nunca conseguirão atingir o nível de complexidade de cada indivíduo de maneira a proteger todas e todos indistintamente. Por conta disso, nosso verdadeiro horizonte não se restringe à alteração da legislação de proteção contra doenças e acidentes relacionados ao trabalho, mas a mudança global dos modos de organização da produção hoje existentes, para que o trabalho deixe de ser causador de sofrimento e torne-se fonte de desenvolvimento das potencialidades de mulheres e homens. E isso é parte de uma transformação geral e objetiva dessa sociedade, que inclui também mudanças nas relações de gênero.

Não podemos nunca perder de vista que nossos debates sobre o Direito do Trabalho e a proteção do bem-estar de trabalhadoras e trabalhadores são sempre, simultaneamente, debates econômicos, morais e políticos sobre igualdade, tanto de gênero quanto de classe e raça, e sobre as possibilidades de avanço social. É esta trama que está em jogo, e afastar os fundamentos sexistas do ordenamento jurídico é remover os primeiros obstáculos para buscarmos a igualdade que sonhamos e queremos. 


\section{Bibliografia}

ABRAHÃO, Júlia Issy; MASCIA, Fausto Leopoldo; MONTEDO, Uiara Bandineli; SZNELWAR, Laerte Idal. Contribuição da ergonomia para a transformação e melhoria da organização e do conteúdo do trabalho. In: MENDES, René (org.). Patologia do Trabalho. $3^{\mathrm{a}}$ ed. São Paulo: Atheneu, 2013. p. 1639-1654.

ABRAMO, Laís (ed.). Questionando um mito: custos do trabalho de homens e mulheres. Brasília: OIT, 2005.

ACEVEDO, Doris. Género y políticas de protección laboral: protección a la maternidad y la familia en la Ley Orgánica del Trabajo de Venezuela. Salud de los Trabajadores, Maracay, v.12, n.1, p. 33-53, 2004.

ACEVEDO, Doris; BIAGGII, Yajaira; BORGES, Glanés. Violencia de género en el trabajo: acoso sexual y hostigamiento laboral. Revista Venezolana de Estudios de la Mujer [online], v. 14, n. 32, p. 163-182, 2009.

ACGIH. 2011: TVLs \& BEIs. Tradução: Associação Brasileira de Higienistas Ocupacionais. São Paulo: ABHO, 2011.

ADDATI, Laura; CASSIRER, Naomi; GILCHRIST, Katherine. Maternity and paternity at work: law and practice across the world. Genebra: OIT, 2014.

AGUILERA IZQUIERDO, Raquel. Los derechos de conciliación de la vida personal, familiar y laboral en la Ley Orgánica para la igualdad efectiva de mujeres y hombres. Revista Del Ministerio De Trabajo y Asuntos Sociales, Madrid, n. extra 2, p. 69-119, 2007.

ALVES, Giovanni. O adoecimento do trabalho como falha metabólica do capital. In: LOURENÇO, Edvânia Ângela De Souza; NAVARRO, Vera Lucia (orgs.). O avesso do trabalho III: saúde do trabalhador e questões contemporâneas. São Paulo: Outras expressões, 2013.

ANDRADE, Maria de los Angeles Garduño. A saúde no trabalho de homens e mulheres: uma visão de gênero. In: OLIVEIRA, Eleonora Menicucci de; SCAVONE, Lucila. (org). Trabalho, Saúde e Gênero na era da globalização. Goiânia: AB Editora, 1997.

ANGOTTI, Bruna. A Constituição Federal de 1988 e a conquista formal dos direitos das mulheres. Cadernos da Escola do Parlamento: VI - Igualdade de Gênero I. São Paulo: Câmara Municipal, 2014.

ANTUNES, Ricardo. A corrosão do trabalho e a precarização estrutural. In: LOURENÇO, Edvânia Ângela De Souza; NAVARRO, Vera Lucia (orgs.). O avesso do trabalho III: saúde do trabalhador e questões contemporâneas. São Paulo: Outras expressões, 2013. p. 22-27. 
Os sentidos do trabalho: ensaio sobre a afirmação e a negação do trabalho.

São Paulo: Boitempo, 2009..

APPAY, Béatrice; THÉBAUD-MONY, Annie. Precarização social. In: HIRATA, Helena; LABORIE, Françoise; LE DOARÉ, Hélène; SENOTIER, Danièle (org.). Dicionário Crítico do Feminismo. São Paulo: Editora Unesp, 2009. p. 193-198.

AQUINO, Estela M. L. Gênero e saúde: perfil e tendências da produção científica no Brasil. Revista de Saúde Pública, São Paulo, n. 40, p. 121-132, 2006.

ARAÚJO, Angela Maria Carneiro; OLIVEIRA, Eleonora Menicucci. Reestruturação produtiva e saúde no setor metalúrgico: a percepção das trabalhadoras. Sociedade e Estado, Brasília, v.21, n.1, p. 169-198, 2006.

ASCHWANDEN, Christie. Harassment in Science, Replicated. The New York Times, New York, 11.ago.2014. Disponível em: <http://www.nytimes.com/ 2014/08/12/science/harassment-in-science-replicated.html?_r=0>. Acesso em: 15.ago.2014.

ASSUNÇÃO, Ada Ávila; VILELA, Lailah Vasconcelos Oliveira. Lesões por esforços repetitivos: guia para profissionais de saúde. Piracicaba: Centro de Referência em Saúde do Trabalhador - CEREST, 2009.

BADINTER, Elisabeth. O conflito: a mulher e a mãe. Rio de Janeiro: Record, 2011.

Fronteira, 1985.

Um amor conquistado: $O$ mito do amor materno. Rio de Janeiro: Nova

BARRETO, Margarida. Violência, saúde e trabalho: uma jornada de humilhações. São Paulo: EDUC, 2013.

Lesões por esforços repetitivos (LER): que danos causam no cotidiano das mulheres. In: OLIVEIRA, Eleonora Menicucci de; SCAVONE, Lucila. (org). Trabalho, Saúde e Gênero na era da globalização. Goiânia: AB Editora, 1997. p. 87- 100.

O trabalho engendrando doenças e diferenças. In: BARRETO, Margarida; CARLOTO, Cássia Maria; COSTA, Maria Luiza da. Saúde das Trabalhadoras. São Paulo: SOF Sempreviva Organização Feminista, 1998. p. 59-79.

Urge um olhar de gênero para compreender o adoecer no trabalho. In: INSTITUTO LATINOAMERICANO DE EDUCAÇÃO INTEGRAL. Um olhar de gênero na saúde e segurança no trabalho. ILEI: São Paulo, nov.2005. p. 7-10.

EDUC, 2013

Violência, saúde e trabalho: uma jornada de humilhações. São Paulo:

BARRETO, Margarida; HELOANI, Roberto. Assédio laboral e as questões contemporâneas à saúde do trabalhador. LOURENÇO, Edvânia Ângela De Souza; NAVARRO, Vera Lucia (orgs.). $O$ avesso do trabalho III: saúde do trabalhador e questões contemporâneas. São Paulo: Outras expressões, 2013. p. 107- 141. 
BARROS, Alice Monteiro de. A Mulher e o Direito do Trabalho. São Paulo: LTR, 1995.

O trabalho da mulher: revisão de conceitos. In: PENIDO, Laís de Oliveira (coord.). Igualdade dos gêneros nas relações de trabalho. Brasília: ESMPU, 2006. p. 51-82.

BARROSO, Carmem. Trabalho e Saúde da Mulher. Revista Brasileira de Saúde Ocupacional, Ministério do Trabalho / Fundacentro, v. 38, n. 10, p. 7-11, abr/mai/jun.1982.

BERCOVICI, Gilberto; MASSONETTO, Luis Fernando. Breve História da Incorporação dos Direitos Sociais nas Constituições Democráticas Brasileiras. Revista do Departamento de Direito do Trabalho e da Seguridade Social, v. 3, p. 61-84, 2007.

BERTOLIN, Patrícia Tuma Martins. KAMADA, Fabiana Larissa. Ausentes ou invisíveis? A participação das mulheres nos sindicatos. Caderno Espaço Feminino. Uberlândia, v.25, n.1, p. 28-52, jan/jun 2012.

BERTOLIN, Patrícia Tuma Martins; CARVALHO, Suzete. A segregação ocupacional da mulher: será a igualdade jurídica suficiente para superá-la? In: BERTOLIN, Patrícia Tuma Martins; ANDREUCCI, Ana Claudia Pompeu Torezan (org). Mulher, sociedade e direitos humanos. São Paulo: Rideel, 2010. p. 179-210.

BILAC, Elisabete. Trabalho e família: articulações possíveis. Tempo social [online], v.26, n.1, p. 129-145, 2014.

BLASS, Leila; HIRATA, Helena; SOARES, Vera. Prefácio à $2^{a}$ edição. SOUZALOBO, Elizabeth. A classe operária tem dois sexos: trabalho, dominação e resistência. 2 ed. São Paulo: Editora Fundação Perseu Abramo, 2011. p. 9-20.

BOCK, Gisela. História, história das mulheres, história do género. Penélope: Revista de História e Ciências Sociais [online], n. 4, p. 147-178, $1990 .$.

BONCIANI, Mario. Normas Regulamentadoras e a questão de gênero no trabalho. In: INSTITUTO LATINOAMERICANO DE EDUCAÇÃO INTEGRAL. Um olhar de gênero na saúde e segurança no trabalho, ILEI, São Paulo, nov. 2005. p. 24-25.

BOURDIEU, Pierre. A dominação masculina. Rio de Janeiro: Best Bolso, 2014.

Novas reflexões sobre a dominação masculina. In: LOPES, Marta Julia Marques; MEYER, Dagmar Estermann; WALDOW, Vera Regina. Gênero \& Saúde. Porto Alegre: Artes Médicas, 1996. p. 28-40.

BRANDÃO, Cláudio. Meio ambiente do trabalho saudável: direito fundamental do trabalhador. Revista do Tribunal Regional do Trabalho da $1^{a}$ Região, v. 21, n. 49, p. 8998, jan./jun. 2011.

BRASIL. Anuário Estatístico da Previdência Social: AEPS 2013. Brasília: Ministério da Previdência Social, 2012. 
LER/DORT: dilemas, polêmicas e dúvidas. Brasília: Ministério da Saúde, 2001.

Relatório Anual Socioeconômico da Mulher 2013. Brasília: Secretaria de Políticas para as Mulheres, 2013.

BRASIL; CENTRO BRASILEIRO DE ANÁLISE E PESQUISA. Pesquisa Nacional de Demografia e Saúde da Criança e da Mulher: PNDS 2006. Brasília: Ministério da Saúde, 2006.

BRITO, Jussara Cruz de; MATTOS, Ubirajara; SOARES, Vanda D'A.; FERREIRA, Heloisa P. Saúde das trabalhadoras: o caso da lavanderia de uma indústria química de cloro-soda. Cadernos de Saúde Pública, Rio de Janeiro, v. 11, n. 4, p. 543-551, out/dez 1995

BRITO, Jussara Cruz de. Enfoque se gênero e relação saúde/trabalho no contexto de reestruturação produtiva e precarização do trabalho. Caderno de Saúde Pública, Rio de Janeiro, n. 16, v. 1, p. 195-204, jan-mar 2000.

BRITO, Jussara Cruz de; NEVES, Mary Yale; OLIVEIRA, Simone Santos; ROTENBERG, Lucia. Saúde, subjetividade e trabalho: o enfoque clínico e de gênero. Revista Brasileira de Saúde Ocupacional, São Paulo, v. 37, n. 126, p. 316-329, 2012.

BRITO, Maria Noemi Castilhos. Gênero e cidadania: referenciais analíticos. Estudos Feministas, Florianópolis, v.9, n.1, p. 291-298, 2001.

BRUMER, Anita. O sexo da ocupação: Considerações teóricas sobre a inserção da mão de obra feminina na força de trabalho. Revista Brasileira de Ciências Sociais, v. 3, n. 8, São Paulo, out. 1988. Disponível em: <http://portal.anpocs.org /portal/index.php?option=com_ content\&view =article\&id=229:rbcs-08\&catid=69: rbcs\&Itemid=399\#2>. Acesso em: 3.ago.2014.

BRUSCHINI, Cristina. Gênero e trabalho no Brasil: novas conquistas ou persistência da discriminação? In: ROCHA, Maria Isabel Baltar da. (org). Trabalho e Gênero: Mudanças, Permanências e Desafios. São Paulo: Editora 34, 2000. p. 13-58.

BRUSCHINI, Cristina; COSTA, Albertina de Oliveira da (orgs.). Uma questão de gênero. Rio de Janeiro: Rosa dos Tempos, 1992.

BRUSCHINI, Cristina; LOMBARDI, Maria Rosa. A bipolaridade do trabalho feminino no Brasil contemporâneo. Cadernos de Pesquisa. n. 110. p. 67-104. julho/2010

BUTLER, Judith. Fundamentos contingentes: o feminismo e a questão do "pósmodernismo". Cadernos Pagu, São Paulo, n. 11, p. 11-28, 1998.

CALIL, Léa Elisa Silingowschi. História do direito do trabalho da mulher: aspectos histórico-sociológicos do início da República ao final deste século. São Paulo: LTr, 2000.

CAMPOS-SERNA, Javier; RONDA-PÉREZ, Elena; ARTAZCOZ, Lucía; BENAVIDES, Fernando. Desigualdades de género en salud laboral en España. Gaceta Sanitaria [online], vol.26, n.4, p. 343-351, 2012. 
CARDORE, Marly A. A disciplina jurídica do trabalho da mulher. Revista Brasileira de Saúde Ocupacional, Ministério do Trabalho / Fundacentro, v. 38, n.10, abr/mai/jun.1982.

CARLOTO, Cássia Maria. A saúde das trabalhadoras. In: BARRETO, Margarida; CARLOTO, Cássia Maria; COSTA, Maria Luiza da. Saúde das Trabalhadoras. São Paulo: SOF Sempreviva Organização Feminista, 1998. p. 9-37.

CHEREM, Alfredo Jorge; COIMBRA, Alexandre. Doenças osteomusculares relacionadas com o trabalho: membro superior e pescoço. In: MENDES, René (org.). Patologia do Trabalho. $3^{\mathrm{a}}$ ed. São Paulo: Atheneu, 2013. p. 1391-1421.

COLLEONI, Nelson; CIANCI FILHO, José; ZANETTI, Noemi; KARAGUELIAN, Suely; GIANNETTI, Marcia. O trabalho profissional da gestante e a proteção maternoinfantil. Revista Brasileira de Saúde Ocupacional, Ministério do Trabalho / Fundacentro, v. 38, n.10, abr/mai/jun.1982.

COLLIN, Françoise; LABORIE, Françoise. Maternidade. In: HIRATA, Helena; LABORIE, Françoise; LE DOARÉ, Hélène; SENOTIER, Danièle (org.). Dicionário Crítico do Feminismo. São Paulo: Editora Unesp, 2009. p. 133-138.

COMISSÃO DAS COMUNIDADES EUROPEIAS. Adaptação às transformações do trabalho e da sociedade: uma nova estratégia comunitária de saúde e segurança 20022006. Bruxelas: União Europeia, 2002. Disponível em: <file://C:/Documents\%20and\%20Settings/USER/Meus\%20documentos/ Downloads/com2002_pt.pdf>. Acesso em: 15.ago.2014

CORRÊA, Sônia. Gênero e saúde: campo em transição. In: BRUSCHINI, Cristina;UNBEHAUM, Sandra G. (orgs.). Gênero, democracia e sociedade brasileira. São Paulo: FCC: Editora 34, 2002. p. 357-388

COSTA, Maria Luiza da. LER: A doença do esforço repetitivo. In: BARRETO, Margarida; CARLOTO, Cássia Maria; COSTA, Maria Luiza da. Saúde das Trabalhadoras. São Paulo: SOF Sempreviva Organização Feminista, 1998. p. 38-58.

COUTINHO, Aldacy Rachid. Relações de gênero no mercado de trabalho: uma abordagem da discriminação positiva e inversa. Revista da Faculdade de Direito da Universidade Federal do Paraná, Curitiba, v. 34, p. 13-34, 2000.

DELGADO, Maurício Godinho. Proteções contra discriminação na relação de emprego. In: VIANA, Márcio Túlio; RENAULT, Luiz Otávio Linhares (coord.). Discriminação. São Paulo: LTr, 2000. p. 97-108.

DHOQUOIS, Régine. O direito do trabalho e o corpo da mulher (França: séculos XIX e $\mathrm{XX)}$ : Proteção da produtora ou da reprodutora? In: MATOS, Maria Izilda Santos de; SOIHET, Rachel (org.). Corpo feminino em debate. São Paulo: Editora UNESP, 2003. p. 43-56.

DIAS, Giovana Verri Palma. A gestante exposta ao ruído. In: INSTITUTO LATINOAMERICANO DE EDUCAÇÃO INTEGRAL. Um olhar de gênero na saúde e segurança no trabalho, ILEI, São Paulo, nov.2005. p. 32-33. 
DOARÉ, Hélène le. Do poder político e poiético: esquema de um raciocínio. Estudos Feministas, Florianópolis, Número Especial, p. 65-75, 1994.

DUBAR, Claude. A construção de si pela atividade de trabalho: a socialização profissional. Cadernos de Pesquisa, São Paulo, v. 42, n. 146, p. 351-367, mai./ago.2012.

ERMIDA URIARTE, Oscar. La mujer en el derecho del trabajo: de la protección a la promoción de la igualdad. In: PENIDO, Laís de Oliveira (coord.). Igualdade dos gêneros nas relações de trabalho. Brasília: ESMPU, 2006. p. 115-126.

Prefácio. In: LIMA, Firmino Alves. Teoria da discriminação nas relações de trabalho. Rio de Janeiro: Elsevier, 2011.

ESPAÑA. Herramienta de apoyo $n^{\circ}$ 10: Salud y riesgos laborales con perspectiva de género. Madrid: Ministerio de Sanidad, Servicios Sociales e Igualdad, 2010. Disponível em: <http://www.igualdadenlaempresa.es/recursos/herramientas/home.htm>. Acesso em: 15.ago.2014.

ESQUIVEL, Valeria. Measuring unpaid care work with public policies in mind. Expert Paper prepared for Expert Group Meeting on Structural and Policy Constraints in achieving the MDGs for Women and Girls. Ciudad de México: UN Women in collaboration with ECLAC, 2013. Disponível em: <http://www.unwomen.org/ \%/media/Headquarters/Attachments/Sections/CSW/58/EP3-Valeria-Esquivel\%20.pdf.>. Acesso em: 03.ago.2014.

FARIA, Carlos Aurélio Pimenta de Faria. Entre marido e mulher, o Estado mete a colher: reconfigurando a divisão do trabalho doméstico na Suécia. Revista Brasileira de Ciências Sociais [online], v.17, n.48, p. 173-231, fev.2002.

FARIA, Nalu. Apresentação. In: BARRETO, Margarida; CARLOTO, Cássia Maria; COSTA, Maria Luiza da. Saúde das Trabalhadoras. São Paulo: SOF Sempreviva Organização Feminista, 1998. p. 7-8.

FAUSTO-STERLING, Anne. Dualismos em duelo. Cadernos Pagu, Campinas, n. 1718, p. 7-79, 2002.

Refashioning Race: DNA and the Politics of Health Care. Differences: A Journal of Feminist Cultural Studies, Providence, v.15, n.3, p. 1-37, 2004.

Sexing the body: Gender politics and the construction of sexuality. New York: Basic Books, 2000

The Bare Bones of Sex: Part 1 - Sex and Gender. Signs: Journal of Women in Culture and Society, Chicago, v. 30, n.2, p. 1491-1527, 2005.

FELICIANO, Guilherme Guimarães. Meio ambiente do trabalho (aspectos gerais e propedêuticos). Revista do Tribunal Regional do Trabalho da $15^{a}$ Região, [online], v. 20, p. 1-49, 2002. Disponível em <http://portal.trt15.jus.br/documents/ 124965/125414/Rev20Art12.pdf/c44e2910-96d2-4d0a-9cc5-1c8e64720c2e>. Acesso em: 24.jun.2014. 
. Tutela inibitória em matéria labor-ambiental. Revista do Tribunal Superior do Trabalho, v. 77, n. 4, p. 140-161, out./dez. 2011.

FERNANDES, Maria das Graças de Melo. O corpo e a construção das desigualdades de gênero pela ciência. Revista de Saúde Pública, Rio de Janeiro, v. 19, n. 4, p. 1051-1065, 2009.

FINE, Cordelia. Homens não são de Marte, mulheres não são de Vênus: como a nossa mente, a sociedade e o neurossexismo criam a diferença entre os sexos. São Paulo: Cultrix, 2012.

FONSECA, Rosa Maria Godoy Serpa da. Mulher, direito e saúde: repensando o nexo coesivo. Saúde e Sociedade, São Paulo, n.8, v.2, p. 3-32, 1999.

FORASTIERI, Valentina. Women workers and gender issues on occupational safety and health: Information Note. Genebra: OIT, 2010.

FORSAKRINGSKASSAN. About parental benefits. Stockholm: Forsakringskassan, 2014. Disponível em: <http://www.forsakringskassan.se>. Acesso em: 16.ago.2014.

FOUCAULT, Michel. História da sexualidade I: A vontade de saber. Rio de Janeiro: Edições Graal, 1988.

FRASER, Nancy. Políticas feministas na era do reconhecimento: uma abordagem bidimensional da justiça de gênero. In: BRUSCHINI, Cristina; UNBEHAUN, Sandra (orgs.). Gênero, democracia e sociedade brasileira. São Paulo: FCC, 2002. p. 59-78.

Mapeando a imaginação feminista: da redistribuição ao reconhecimento e à representação. Revista de Estudos Feministas, Florianópolis, v.15, n.2, p. 291-308, mai./ago. 2007. p. 304-305

FREITAS, Maria Ester de; HELOANI, Roberto; BARRETO, Margarida. Assédio moral no trabalho. São Paulo: Cengage Learning, 2009

FUNDAÇÃO EUROPEIA PARA A MELHORIA DAS CONDIÇÕES DE VIDA E DE TRABALHO. Quinto Inquérito Europeu sobre as Condições de Trabalho. União Europeia: $\quad$ Eurofound, 2010. Disponível em <http://www.eurofound.europa.eu/surveys/ewcs/2010/physicalfactors_pt.htm>. Acesso em: 20.ago.2014.

FUNDO DE POPULAÇÃO DAS NAÇÕES UNIDAS. Relatório da Conferência Internacional sobre População e Desenvolvimento - Plataforma de Cairo. Brasília: UNFPA, 1994.

MÁRQUEZ GARMENDIA, Martha. Derecho laboral: ¿igualdad y no discriminación? In: PENIDO, Laís de Oliveira (coord.). Igualdade dos gêneros nas relações de trabalho. Brasília: ESMPU, 2006. p. 139-144

GEORGES, Isabel. Entre vida doméstica e vida profissional: engenheiras no Brasil e na França. In: COSTA, Albertina de Oliveira. SORJ, Bila. BRUSCINI, Cristina. HIRATA, Helena (orgs). Mercado de Trabalho e Gênero: comparações internacionais. Rio de Janeiro: FGV, 2008. p. 245-261 
GLENN, Evelyn Nakano. Cleaning Up/Kept Down: A Historical Perspective on Racial Inequality in "Women's Work". Sanford Law Review. v. 43. n. 6. p. 1333-1356. jul.1991

GLINA, Débora Miriam Raab; SOBOLL, Lis Andreia. Intervenções em assédio moral no trabalho: uma revisão da literatura. Revista brasileira de saúde ocupacional, São Paulo, v. 37, n. 126, p. 269-283, 2012.

GOLDBERG, Anette. Tudo começou antes de 1975: Idéais inspiradas pelo estudo da gestação de um feminismo "bom para o Brasil". In: UNIVERSIDADE DE SÃO PAULO. Relações sociais de gênero x Relações de sexo. São Paulo: Núcleo de Estudos da Mulher e Relações Sociais de Sexo/Departamento de Sociologia, 1989. p. 1-45.

GONZÁLES GÓMEZ, Maria Fernanda. Salud laboral y género: Apuntes para la incorporación de la perspectiva de género en el ámbito de la prevención de riesgos laborales. Medicina y Seguridad del trabajo [online], v. 57, supl.1, p. 89-114, 2011.

GRANT, Bridget F.; WEISSMAN, Myrna M. Gênero e prevalência de transtornos psiquiátricos. . In: NARROW, William E.; FIRST, Michael B.; SIROVATKA, Paul J.; REGIER, Darrel A. (org.). Gênero e Idade: Considerações no diagnóstico psiquiátrico. São Paulo: Roca, 2008. p. 28-44.

GRAY, John. Why Mars and Venus Collide: Improving Relationships by Understanding How Men and Women Cope Differently with Stress. London: Harper Collins, 2008.

GUIMARÃES, Nadya Araujo; HIRATA, Helena (org.) Cuidado e cuidadoras: as várias faces do trabalho do care. São Paulo: Atlas, 2012.

HEINEN, Jacqueline. Políticas sociais e familiares. In: HIRATA, Helena; LABORIE, Françoise; LE DOARÉ, Hélène; SENOTIER, Danièle (org.). Dicionário Crítico do Feminismo. São Paulo: Editora Unesp, 2009. p. 188-193.

HESS, Beth. B. Beyond Dichotomy: drawing distinctions and embracing differences. Sociological Forum, v. 5, n. 1, p. 75-93, 1990..

HIGA, Flavio da Costa; VIEIRA, Regina Stela Corrêa. Proteção ou discriminação? Passando a limpo algumas normas de tutela do trabalho da mulher? Revista do Tribunal Superior do Trabalho, v. 21, n.1, Rio de Janeiro, p. 56-72, set./dez.2013

HIRATA, Helena. Divisão-relações sociais de sexo e do trabalho: contribuições à discussão sobre o conceito de trabalho. Em aberto, Brasília, ano 15, n. 65, jan./mar.1995.

Globalização e divisão sexual do trabalho. Cadernos Pagu, Campinas, n. 1718, p. 139-156, 2002.

Nova Divisão Sexual do Trabalho? Um olhar voltado para a empresa e a sociedade. São Paulo: Boitempo, 2002.

O trabalho do cuidado (care) em perspectiva comparada: França, Japão e Brasil. In: ABREU, Maria Aparecida (org). Redistribuição, reconhecimento $e$ representação: Diálogos sobre igualdade de gênero. Brasília: IPEA, 2011. p. 83-107. 
Reestruturação produtiva, trabalho e relações de gênero. Revista LatinoAmericana de Estudos do Trabalho, ano 4, n. 7, p. 5-27, 1998.

. Reorganização da produção e transformações do trabalho: uma nova divisão sexual do trabalho? In: BRUSCHINI, Cristina; UNBEHAUN, Sandra (orgs.). Gênero, democracia e sociedade brasileira. São Paulo: FCC, 2002. p. 339-355.

HIRATA, Helena; CATTANÉO, Nathalie. Flexibilidade. In: HIRATA, Helena; LABORIE, Françoise; LE DOARÉ, Hélène; SENOTIER, Danièle (org.). Dicionário Crítico do Feminismo. São Paulo: Editora Unesp, 2009. p. 106-111.

HIRATA, Helena; KERGOAT, Danièle. Novas configurações da divisão sexual do trabalho. Cadernos de Pesquisa. V. 37, n. 132, p. 595-609, set./dez.2007.

Divisão sexual do trabalho profissional e doméstico: Brasil, França, Japão. In: COSTA, Albertina de Oliveira. SORJ, Bila. BRUSCINI, Cristina. HIRATA, Helena (orgs). Mercado de Trabalho e Gênero: comparações internacionais. Rio de Janeiro: FGV, 2008. p. 263-278.

HIRIGOYEN, Marie-France. Assédio moral: a violência perversa no cotidiano. Rio de Janeiro: Bertrand Brasil, 2002.

HOCHSCHILD, Arlie Russell. Emotion Work, Feeling Rules, and Social Structure. American Journal of Sociology, v. 85, n. 3, p. 551-575, nov. 1979.

HOFMEISTER, Vera Anna. Estudo do término de gestações de trabalhadoras em indústrias. Revista Brasileira de Saúde Ocupacional, Ministério do Trabalho / Fundacentro, v. 38, n. 10, p. 38-42, abr/mai/jun. 1982.

INSTITUTO BRASILEIRO DE GEOGRAFIA E ESTATÍSTICA. Pesquisa Nacional por Amostra de Domicílios: Síntese de Indicadores 2012. Rio de Janeiro: IBGE, 2013.

Síntese de indicadores sociais: uma análise das condições de vida da população brasileira. Rio de Janeiro: IBGE, 2009..

INSTITUTO NAVARRO DE SALUD LABORAL. Ficha técnica de prevención 35 Mujeres y Salud Laboral: Prevención de riesgos laborales desde la perspectiva de género. Navarra: Gobierno de Navarra, 2011

JOSHI, Heather; DAVIES, Hugh. Day care in Europe and mothers' forgone earnings. International Labour Review, Genebra, v.131, n. 6, p. 561-579, 1992.

KERGOAT, Danièle. Dinâmica e consubstancialidade das relações socais. Novos Estudos - CEBRAP [online], n. 86, p. 93-103, mar./2010.

Divisão sexual do trabalho e relações sociais de sexo. In: HIRATA, Helena; LABORIE, Françoise; LE DOARÉ, Hélène; SENOTIER, Danièle (org.). Dicionário Crítico do Feminismo. São Paulo: Editora Unesp, 2009. p. 67-75.

Relações sociais de sexo e divisão sexual do trabalho. In: LOPES, Marta Julia Marques; MEYER, Dagmar Estermann; WALDOW, Vera Regina. Gênero \& Saúde. Porto Alegre: Artes Médicas, 1996. p. 19-27. 
KERGOAT, Prisca; PICOT, Geneniève; LADA, Emmanuelle . Ofício, profissão, 'bico'. In: HIRATA, Helena; LABORIE, Françoise; LE DOARÉ, Hélène; SENOTIER, Danièle (org.). Dicionário Crítico do Feminismo. São Paulo: Editora Unesp, 2009. p. 159-167.

LIMA, Firmino Alves. Teoria da discriminação nas relações de trabalho. Rio de Janeiro: Elsevier, 2011.

LIMA, Maria Elizabeth Antunes. A discriminação no contexto do trabalho - o caso dos portadores de lesões por esforços repetitivos. In: VIANA, Márcio Túlio; RENAULT, Luiz Otávio Linhares (coord.). Discriminação. São Paulo: LTr, 2000.

LLORCA RUBIO, José Luis; GIL-MONTE, Pedro R. Prevención de riesgos laborales y su relación con el género de los trabajadores. Saúde e Sociedade, São Paulo, v.22, n.3, p.727-735, 2013.

LOBO, Elisabeth Souza. O trabalho como linguagem: o gênero do trabalho. In: BRUSCHINI, Cristina; COSTA, Albertina de Oliveira da (orgs.). Uma questão de gênero. Rio de Janeiro: Rosa dos Tempos, 1992. p. 252-265.

LOPES, Cristiane Maria Sbalqueiro. A efetivação do direito à creche no Brasil. Revista do Ministério Público do Trabalho, Brasília, n.40, p. 38-60, set.2010.

Direito do trabalho da mulher: da proteção à promoção. Cadernos Pagu, Campinas, n. 26, p. 405-430, 2006.

LOURO, Guacira Lopes. Nas redes do conceito de gênero. In: LOPES, Marta Julia Marques; MEYER, Dagmar Estermann; WALDOW, Vera Regina. Gênero \& Saúde. Porto Alegre: Artes Médicas, 1996. p. 7-18.

LUDERMIR, Ana Bernarda. Inserção produtiva, trabalho e saúde mental. Cadernos de Saúde Pública, Rio de Janeiro, v. 16, n. 3, p. 647-659, jul./set. 2000.

LUXON, Meg. The UN, women, and household labour: Measuring and valuing unpaid work. Women's Studies International Forum, v.20, n.3, p. 431-439, 1997.

MACRAE, Nancy. Women and work: a ten year retrospective. Work: A Journal of Prevention, Assessment and Rehabilitation [online], v. 24, p. 331-339, 2005.

MAENO, Maria. LER/DORT: Problema de mulheres. In: INSTITUTO LATINOAMERICANO DE EDUCAÇÃO INTEGRAL. Um olhar de gênero na saúde e segurança no trabalho, ILEI, São Paulo, nov.2005. p. 18-19.

. Por que conversamos ainda sobre LER/DORT? São Paulo: FETEC-SP, 2011. Disponível em: <http://www.fetecsp.org.br/ index.php?option= com_content\&view=article\&id=50263: $\quad$ artigo-por-que-conversamos-ainda-sobrelerdort\&catid=39: saude \&Itemid=143>. Acesso em: 15.ago. 2014 .

MALLET, Estevão. Igualdade e discriminação em direito do trabalho. São Paulo: LTr, 2013.

MARANO, Vicente Pedro. Doenças ocupacionais. São Paulo: LTr, 2003. 
MARCONDES, Willer Baumgartem; ROTENBERG, Lúcia; PORTELA, Luciana Fernandes; MORENO, Claudia Roberta de Castro. O peso do trabalho "leve" feminino à saúde. São Paulo em Perspectiva, São Paulo, v. 17, n. 2, p. 91-101, abr./jun. 2003.

MATHIEU, Nicole-Claude. Sexo e gênero. In: HIRATA, Helena; LABORIE, Françoise; LE DOARÉ, Hélène; SENOTIER, Danièle (org.). Dicionário Crítico do Feminismo. São Paulo: Editora Unesp, 2009. p. 222-231.

MATIAS, Marisa; FONTAINE, Anne Marie. A Conciliação de Papéis Profissionais e Familiares: O Mecanismo Psicológico de Spillover. Psicologia: Teoria e Pesquisa [online], v. 28, n. 2, p. 235-243, abr./jun.2012.

MATTAR, Laura Davis. Direitos maternos: uma perspectiva possível dos direitos humanos para o suporte social à maternidade. Tese (Doutorado). Faculdade de Saúde Pública da Universidade de São Paulo. Orientadora Carmen Simone Grilo Diniz. São Paulo, 2001.

MELO, Érica. Feminismo: velhos e novos dilemas uma contribuição de Joan Scott. Cadernos Pagu, Campinas, n. 31, p. 553-564, 2008.

MELO, Raimundo Simão de. Direito ambiental do trabalho e a saúde do trabalhador. 5. ed. São Paulo: LTr, 2013.

MENDES, Aline. Olhar diferenciado: homens e mulheres têm necessidades distintas no trabalho. Revista Proteção, n. 174, ano XIX, jun/2006.

MESSING, Karen; STELLMAN, Jeanne Mager. Sex, gender and women's occupational health: the importance of considering mechanism. Environmental Research [online], v.101, p. 149-162, 2006.

MILLER, Claire Cain. Paid Leave Encourages Female Employees to Stay. The New York Times, New York, 28.jul.2014. Disponível em: <http://www.nytimes.com/2014/07/29/upshot/how-paid-leave-helps-female-employeesstay-.html?_r=0\&abt=0002\&abg=1>. Acesso em: 15.ago.2014.

MOORE, Henrietta. Understanding Sex and gender. In INGOLD, Tim (org.). Companion Encyclopedia of Antropology. London: Routledge, 1997. (Tradução de Júlio Assis Simões para uso didático)..

MORAES, Monica Maria Lauzid de. O direito à saúde e segurança no meio ambiente do trabalho: proteção, fiscalização e efetividade normativa. São Paulo: LTr, 2002. p. 27.

NARROW, William E. Prefácio. In: NARROW, William E.; FIRST, Michael B.; SIROVATKA, Paul J.; REGIER, Darrel A. (org.). Gênero e Idade: Considerações no diagnóstico psiquiátrico. São Paulo: Roca, 2008. p. VII-X.

NASCIMENTO, Amauri Mascaro do. Iniciação ao Direito do Trabalho. São Paulo: LTR, 2000. 
NEVES, Ilídio Roda. LER: trabalho, exclusão, dor, sofrimento e relação de gênero. Um estudo com trabalhadoras atendidas num serviço público de saúde. Cadernos de Saúde Pública, Rio de Janeiro, v. 22, n. 6, p. 1257-1265, jun.2006

NEVES, Magda de Almeida. Reestruturação produtiva, qualificação e relações de gênero. In: ROCHA, Maria Isabel Baltar da. (org). Trabalho e Gênero: Mudanças, Permanências e Desafios. São Paulo: Editora 34, 2000. p. 171-185.

NOGUEIRA, Diogo Pupo. Trabalho de Mulheres. Revista Brasileira de Saúde Ocupacional, Ministério do Trabalho / Fundacentro, v. 38, n. 10, p. 12-16, abr/mai/jun.1982.

NOVAIS, Denise Pasello Valente. Discriminação da mulher e direito do trabalho: da proteção à promoção da igualdade. São Paulo: Dissertação de Mestrado, 2004.

NUNES, Sílvia Alexim. Histeria e psiquiatria no Brasil da Primeira República. História, Ciências, Saúde - Manguinhos, Rio de Janeiro, v. 17, supl. 2, p. 373-389, dez.2010.

OLIVEIRA, Ana Cristina Oliveira de. Gênero, saúde reprodutiva e trabalho: formas subjetivas de viver e resistir às condições de trabalho. Dissertação (Mestrado em Saúde Pública) - Escola Nacional de Saúde Pública, Fundação Oswaldo Cruz, Rio de Janeiro. 2001.

OLIVEIRA, Eleonora Menicucci de. A mulher, a sexualidade e o trabalho. São Paulo: CUT, 1999.

Corpos saudáveis e corpos doentes na nova organização social do trabalho. In: ROCHA, Maria Isabel Baltar da. (org). Trabalho e Gênero: Mudanças, Permanências e Desafios. São Paulo: Editora 34, 2000. p. 237-256.

Gênero, saúde e trabalho: um olhar transversal. In: OLIVEIRA, Eleonora Menicucci de; SCAVONE, Lucila. (org). Trabalho, Saúde e Gênero na era da globalização. Goiânia: AB Editora, 1997. p. 1-14.

OLIVEIRA, Eleonora Menicucci de; BARRETO, Margarida. Engendrando gênero na compreensão das lesões por esforços repetitivos. Saúde e Sociedade [online], v. 6, n. 1, p. 77-99, 1997. p. 81-82.

OLIVEIRA, Simone. Gênero, Organização do Trabalho e Saúde. In: Encontro Nacional de Engenharia de Produção, 1997, Rio de Janeiro. Anais do ENEGEP 1997. Rio de Janeiro: ABEPRO, 1997. 9p.

ORGANIZAÇÃO INTERNACIONAL DO TRABALHO. Introductory report: global trends and challenges on occupational safety and health: XIX World Congress on Safety and Health at Work: Istanbul Turkey, 11-15 September 2011. Genebra: OIT, 2011.

A prevenção das doenças profissionais: relatório para o Dia Mundial da Segurança e Saúde no Trabalho. Geneva: OIT, 2013. 
El hostigamiento o acoso sexual. Genebra: OIT, 2013. p. 7. Disponível em: <http://www.ilo.org/sanjose/publicaciones/WCMS_227404/lang--es/index.htm>.

Acesso em: 12.set.2014.

Módulo de capacitação em inspeção do trabalho e igualdade de gênero. Brasília: OIT, 2012.

$O A B C$ dos direitos das mulheres trabalhadoras e da igualdade de género.

Genebra: OIT, 2007

ORGANIZAÇÃO MUNDIAL DA SAÚDE. Constitution of the World Health Organization. New York: OMS, 1948. Disponível em <http://www.who.int/governance/eb/who_constitution_en.pdf >. Acesso em: 10.jun.2013.

ORGANIZAÇAO PANAMERICANA DE SAÚDE. Saúde nas Américas: Edição de 2012. Washington: OPAS, 2012.

ORTNER, Sherry B. Está a mulher para o homem assim como a natureza para a cultura? In: ROSALDO, Michelle; LAMPHERE, Louise. A mulher, a cultura e a sociedade. Rio de Janeiro: Paz e Terra, 1979. p. 95-120.

PACHECO, Vanise Goulart. Gênero, saúde e trabalho: fatores que interagem no desenvolvimento de LER em trabalhadores telefônicos. Dissertação (Mestrado em Psicologia) - Faculdade de Filosofia e Ciências Humanas, Universidade Federal de Minas Gerais, Minas Gerais. Março, 2002.

PAMPLONA FILHO, Rodolfo. Assédio sexual na relação de emprego. São Paulo: LTr, 2001.

PAULILO, Maria Ignez S. O peso do trabalho leve. Revista Ciência Hoje, n. 28, 1987.

PAUMGARTTEN, Francisco J.R. Doenças da Reprodução e malformações congênitas relacionadas com o trabalho. In: MENDES, René (org.). Patologia do Trabalho. $3^{\mathrm{a}}$ ed. São Paulo: Atheneu, 2013. p. 1479-1504.

PÉREZ CAMPOS, Ana Isabel. Salud laboral y trabajo femenino: mecanismos de protección y prevención. Anuario Jurídico y Económico Escurialense, La Rioja, n.40, p. 195-228, 2007.

PERROT, Michelle. História (sexuação da). In: HIRATA, Helena; LABORIE, Françoise; LE DOARÉ, Hélène; SENOTIER, Danièle (org.). Dicionário Crítico do Feminismo. São Paulo: Editora Unesp, 2009. p. 111-116.

Os excluídos da história. Rio de Janeiro: Paz e Terra, 1988.

PETERSEN, Áurea T. Discutindo o uso da categoria gênero e as teorias que respaldam estudos de gênero. In: STREY, Marlene Neves (org.) et al. Gênero por Escrito: saúde, identidade e trabalho. Porto Alegre: EDIPUCRS, 1999. p. 15-39. 
PHILLIPS, Katharine A.; FIRST, Michael B. Introdução. In: NARROW, William E.; FIRST, Michael B.; SIROVATKA, Paul J.; REGIER, Darrel A. (org.). Gênero e Idade: Considerações no diagnóstico psiquiátrico. São Paulo: Roca, 2008. p. 2-5.

PIOVESAN, Flávia. Direitos humanos das mulheres no Brasil: desafios e perspectivas. In: PENIDO, Laís de Oliveira (coord.). Igualdade dos gêneros nas relações de trabalho. Brasília: ESMPU, 2006. p. 205-212.

PIOVESAN, Flávia; RIOS, Roger Raup. A discriminação por gênero e por orientação sexual. Série Cadernos do CEJ, v. 4, p. 154-175, 2003. Disponível em: <http://daleth.cjf.jus.br/revista/seriecadernos/vol24/artigo05.pdf >. Acesso em: 15.ago.2014.

PRÁ, Jussara Reis; EPPING, Léa. Cidadania e feminismo no reconhecimento dos direitos humanos das mulheres. Estudos Feministas, Florianópolis, v.20, n.1, p. 33-51, jan./abr.2012.

PRONI, Thaíssa Tamarindo Da Rocha Weishaupt. Proteção constitucional à maternidade no Brasil: um caso de expansão da garantia legal. Dissertação (Mestrado em Direito). Faculdade de Direito da Universidade de São Paulo. Orientador Antonio Rodrigues De Freitas Junior. São Paulo, 2012.

RÉA, Marina Ferreira. Benefícios à mãe trabalhadora: conquistas e recuos nas políticas públicas. In: BRUSCHINI, Cristina; UNBEHAUM, Sandra G. (orgs.). Gênero, democracia e sociedade brasileira. São Paulo: FCC: Editora 34, 2002. p. 389-402.

REA, Marina Ferreira; VENÂNCIO, Sonia Isoyama; BAISTA, Luis Eduardo; SANTOS, Rosangela Gomes dos; GREINER, Ted. Possibilidades e limitações da amamentação entre mulheres trabalhadoras formais. Revista de Saúde Pública, São Paulo, n. 2, v. 31, p. 402-416, abril/1997

REGITZ-ZAGROSEK, Vera. Sex and gender differences in health. Science \& Society, New York, v.13, n.7, p. 596-603, 2012.

RIBAULT, Thierry. Cuidadoras domiciliares: que tipo de profissionalização? In GUIMARÃES, N. A. HIRATA, H. S. (org.) Cuidado e cuidadoras: as várias faces do trabalho do care. São Paulo: Atlas, 2012.

RIBEIRO, Herval Pina. Lesões por esforços repetitivos (LER): uma doença emblemática. Cadernos de Saúde Pública, Rio de Janeiro, v.13, Supl. 2, p. 85-93, 1997.

ROCHA, Julio Cesar de Sá da. Direito ambiental do trabalho. São Paulo: LTr, 2002.

ROHDEN, Fabíola. A construção da diferença sexual na medicina. Cadernos de Saúde Pública, Rio de Janeiro, n. 19, Sup. 2, p. 201-212, 2003 out.1998.

O corpo fazendo a diferença. Mana, Rio de Janeiro, v.4, n.2, p. 127-141,

Uma ciência da diferença: sexo e gênero na medicina da mulher. Rio de Janeiro: Editora FIOCRUZ, 2001. 
ROMITO, Patrizia. Trabalho, maternidade e saúde das mulheres: algumas notas metodológicas. In: OLIVEIRA, Eleonora Menicucci de; SCAVONE, Lucila. (org). Trabalho, Saúde e Gênero na era da globalização. Goiânia: AB Editora, 1997. p. 1527.

ROSHCHIN, A. V. Protection of the Working Environment. International Labour Review, v. 110, n. 3, p. 235-249, 1974. Disponível em <http://heinonline.org $/$ HOL/LandingPage?handle $=$ hein.journals/intlr110\&div $=30 \& i d=\&$ page $=>$. Acesso em: 02.jul.2014.

ROTEMBERG, Lúcia; PORTELA, Luciana Fernandes; MARCONDES, Willer Baumgartem; MORENO, Cláudia; NASCIMENTO, Cristiano de Paula. Gênero e trabalho noturno: sono, cotidiano e vivência de quem troca a noite pelo dia. Cadernos de Saúde Pública, Rio de Janeiro, n. 17, v. 3, p. 639-649, 2001.

ROURE, Sarah de; VIEIRA, Regina Stela Corrêa. Autonomia das mulheres e as políticas de creche em São Paulo: considerações iniciais. In: III Simpósio de Gênero e Políticas Públicas, 2014, Londrina. Anais do III Simpósio de Gênero e Políticas Públicas, 2014. Disponível em: <http://www.uel.br/eventos/ gpp/pages/arquivos/GT2_Sarah\%20de\%20Roure\%20e\%20Regina\%20Stela\%20Vieira. pdf>. Acesso em: 15.ago.2014.

SAFFIOTI, Heleieth I. B. Gênero, patriarcado, violência. São Paulo: Fundação Perseu Abramo, 2004.

Rearticulando gênero e classe social. In: BRUSCHINI, Cristina; COSTA, Albertina de Oliveira da (orgs.). Uma questão de gênero. Rio de Janeiro: Rosa dos Tempos, 1992. p. 183-215.

Força de Trabalho feminina no Brasil: no interior das cifras. Perspectivas, São Paulo. v. 8, p. 95-141, 1985.

SALAS, Carlos. LEITE, Marcia. Segregação setorial por gênero: uma comparação Brasil-México. In: COSTA, Albertina de Oliveira. SORJ, Bila. BRUSCINI, Cristina. HIRATA, Helena (orgs). Mercado de Trabalho e Gênero: comparações internacionais. Rio de Janeiro: FGV, 2008.

SALIM, Celso Amorim. Doenças do Trabalho: exclusão, segregação e relações de gênero. São Paulo em Perspectiva [online], v. 17, n. 1, p. 11-24, 2003.

SÁNCHEZ CASTILLO, Mercedez. Lactancia y salud laboral: crónica de una situación insuficientemente protegida. In: PENIDO, Laís de Oliveira (coord.). Igualdade dos gêneros nas relações de trabalho. Brasília: ESMPU, 2006. p. 277-304.

SANTANA, Vilma; MAIA, Antonio P.; CARVALHO, Cláudia; LUZ, Glaura. Acidentes de trabalho não fatais: diferenças de gênero e tipo de contrato de trabalho. Cadernos de Saúde Pública, Rio de Janeiro, v. 19, n. 2, p. 481-493, mar./abr. 2003.

SCAVONE, Lucila. A maternidade e o feminismo: diálogo com as ciências sociais. Cadernos Pagu, Campinas, n. 16, p. 137-150, 2001 
SCHEIN, Virginia E.; MUELLER, Ruediger. Sex role stereotyping and requisite management characteristics: A cross cultural look. Journal of Organizational Behavior, v.13, p. 439-447, 1992.

SCHEIN, Virginia E.; MUELLER, Ruediger; LITUCHY, Terri; LIU, Jiang. Think manager-think male: a global phenomenon? Journal of Organizational Behavior, v. 17, p. 31-44, 1996.

SCHIRMER, Janine. Trabalho e maternidade: qual o custo para as mulheres? In: OLIVEIRA, Eleonora Menicucci de; SCAVONE, Lucila. (org). Trabalho, Saúde e Gênero na era da globalização. Goiânia: AB Editora, 1997.

SCOTT, Joan W. Deconstructing Equality-Versus-Difference: Or, the uses of PostStructuralist Theory for Feminism. Feminist Studies, Maryland, v. 14, n. 1, p. 33-50, 1988 $30 \mathrm{abr} . / 2005$.

O enigma da igualdade. Estudos Feministas, Florianópolis, v. 13, n.1, p. 11-

Gênero: uma categoria útil de análise histórica. Educação \& Realidade, Porto Alegre, v. 20, n. 2, p. 71-99, jul./dez. 1995.

SELL, Mariléia; OSTERMANN, Ana Cristina. Analise de categorias de pertença (ACP) em estudos de linguagem e gênero: a (des)construção discursiva do homogêneo masculino. Alfa, São Paulo, v. 53, n. 1, p. 11-34, jan.2009.

SELIGMANN-SILVA, Edith. Psicopatologia e saúde mental no trabalho. In: MENDES, René (org.). Patologia do Trabalho. $3^{\mathrm{a}}$ ed. São Paulo: Atheneu, 2013. p. 1051-1114.

SHEAR, Katherine; HALMI, Katherine A.; WIDIGER, Thomas A.; BOYCE, Cheryl. Gênero e fatores socioculturais. In: NARROW, William E.; FIRST, Michael B.; SIROVATKA, Paul J.; REGIER, Darrel A. (org.). Gênero e Idade: Considerações no diagnóstico psiquiátrico. São Paulo: Roca, 2008. p. 63-77.

SILVA, Homero Batista Mateus da. Direito do Trabalho Aplicado, vol. 3: Segurança e medicina do trabalho, trabalho da mulher e do menor. Rio de Janeiro: Elsevier, 2009.

SILVA, José Afonso da. Direito Ambiental Constitucional. 2 ed. São Paulo: Malheiros, 1995.

SILVA, Lorena Holzmann da. Admitimos mulheres, para trabalhos leves. Estudos Feministas, Florianópolis, v. 3, n. 2, p. 349-361, 1995.

SILVEIRA, Nereida Salette Paulo da. Entendendo a experiência de inclusão-exclusão de mulheres em cargos de alta gerência. In: XXXIII Encontro da Associação Nacional de Programas de Pós-graduação e Pesquisa em Administração, 2009, São Paulo. Anais do EnANPAD 2009. Rio de Janeiro: ANPAD, 2009. 14p.

Mulheres gerentes: a centralidade da maternidade na construção da identidade de gênero no trabalho. In: XXXV Encontro da Associação Nacional de Programas de Pós-graduação e Pesquisa em Administração, 2011, Rio de Janeiro. Anais do EnANPAD 2011. Rio de Janeiro: ANPAD, 2011. 
SOARES, Ângelo. Automação, (des)qualificação e emoção nos paraísos de consumo. Cadernos Pagu, Campinas, v. 10, p. 113-146, 1998.

As origens do conceito de assédio moral no trabalho. Revista brasileira de saúde ocupacional, São Paulo, v.37, n.126, p. 284-286, 2012.

SOARES, Ângelo; OLIVEIRA, Juliana Andrade. Assédio moral no trabalho.Revista brasileira de saúde ocupacional, São Paulo, v. 37, n. 126, p. 195-202, 2012.p. 196.

SOARES, Guido Fernando Silva. A proteção internacional do meio ambiente. Barueri: Manole, 2003.

SOARES, Lena Rodrigues; VILLELA, Wilza Vieira.O assédio moral na perspectiva de bancários. Revista brasileira de saúde ocupacional, São Paulo, v.37, n.126, p. 203-212, 2012.

SOARES, Vera. Políticas Públicas para igualdade: o papel do Estado e diretrizes. In: GODINHO, Tatau; SILVEIRA, Maria Lucia da. Políticas Públicas e Igualdade de Gênero. São Paulo: Coordenadoria Especial da Mulher da Prefeitura de São Paulo, 2004. p. 113-126.

SORJ, Bila. Socialização do cuidado e desigualdades sociais. Tempo social [online], v.26, n.1, p. 123-128, 2014.

SORJ, Bila. FONTES, Adriana. O care como um regime estratificado: implicações de gênero e classe social. In: GUIMARÃES, N. A. HIRATA, H. S. (org.) Cuidado e cuidadoras: as várias faces do trabalho do care. São Paulo: Atlas, 2012.

SORJ, Bila; FONTES, Adriana; MACHADO, Danielle. Políticas e Práticas de conciliação entre família e trabalho no Brasil. Cadernos de Pesquisa, v.37, n. 132, p. 573-594, set/dez 2007.

SOUZA-LOBO, Elisabeth. A classe operária tem dois sexos. São Paulo: Editora Fundação Perseu Abramo, 2011.

STATISTICS SWEDEN. Women and men in Sweden. Örebro: SCB, 2014. Disponível em: <http://www.scb.se/Statistik/_Publikationer/LE0201_2013B14_BR_X10BR 1401ENG.pdf>. Acesso em: 16.ago.2014.

TELES, Maria Amélia de Almeida; MEDRADO, Maria Aparecida e GRAGNANI, Adriana Maria Carbonell. Creches e berçários em empresas privadas paulistas. Cadernos de Pesquisa, São Paulo, n.57, p. 39-54, 1986.

THÉBAUD MONY, Annie. Saúde no trabalho. In: HIRATA, Helena; LABORIE, Françoise; LE DOARÉ, Hélène; SENOTIER, Danièle (org.). Dicionário Crítico do Feminismo. São Paulo: Editora Unesp, 2009. p. 217-222.

THOME, Candy Florêncio. A licença-paternidade como desdobramento da igualdade de gênero - um estudo comparativo entre Brasil e Espanha. Revista LTr, São Paulo, v. 74, n. 07, p. 832-838, jul.2010. 
THOME, Candy Florencio. O assédio moral nas relações de emprego. São Paulo: LTr, 2008.

O princípio da igualdade em gênero e a participação das mulheres nas organizações sindicais de trabalhadores. 2012. 343 f. Tese (Doutorado em Direito) Universidade de São Paulo, São Paulo, 2012.

TODESCHINI, Remígio; LINO, Domingos; MELO, Luiz Eduardo Alcântara de. O Ministério da Previdência Social e a institucionalidade no campo da saúde do trabalhador. In: CHAGAS, Ana Maria de Resende Chagas; SALIM, Celso Amorim; SERVO, Luciana Mendes Santos (org.). Saúde e segurança no trabalho no Brasil: aspectos institucionais, sistemas de informação e indicadores. Brasília: Ipea, 2011. p. 77-88.

TORRES, Anita Maria Meinberg Perecim. A saúde da mulher e o meio ambiente do trabalho. São Paulo: LTr, 2007.

TUDOR, Talitha do Carmo. Trabalho da mulher - estágio atual. Revista Brasileira de Saúde Ocupacional, Ministério do Trabalho / Fundacentro, v. 38, n.10, p. 43-47, abr/mai/jun.1982.

VALLEJO, Pilar Rivas. Salud y género: perspectiva de género en la salud laboral. Revista Del Ministerio De Trabajo Y Asuntos Sociales, Madrid, n. Extra 74, p. 227286, 2008.

VARIKAS, Eleni. Igualdade. In: HIRATA, Helena; LABORIE, Françoise; LE DOARÉ, Hélène; SENOTIER, Danièle (org.). Dicionário Crítico do Feminismo. São Paulo: Editora Unesp, 2009. p. 116-122.

Universalismo e particularismo. In: HIRATA, Helena; LABORIE, Françoise; LE DOARÉ, Hélène; SENOTIER, Danièle (org.). Dicionário Crítico do Feminismo. São Paulo: Editora Unesp, 2009. p. 266-271.

VENCATO, Anna Paula. Sapos e princesas: prazer e segredo entre praticantes de crossdressing no Brasil. São Paulo: Annablume, 2013.

VERONESE, Josiane Rose Petry. Os direitos da mulher na nova Constituição. Sequência - Estudos Jurídicos e Políticos, v. 11, n. 21, Florianópolis, p. 94-103, 1990.

VIANA, Márcio Túlio. Os dois modos de discriminar e o futuro do direito do trabalho. In: VIANA, Márcio Túlio; RENAULT, Luiz Otávio Linhares (coord.). Discriminação. São Paulo: LTr, 2000. p. 321-328.

VIDAL, Renata de Queiroz Santana; NETO, Annibal Muiz Silvany. Trabalhadoras brasileiras: características socioeconômicas e ocupacionais e perfil de saúde, Brasil, 2003. Revista Brasileira de Saúde Ocupacional, São Paulo, v. 34, n. 120, p. 115-127, jul/dez.2009.

VIEIRA, Elisabeth Meloni. A medicalização do corpo feminino. Rio de Janeiro: Editora FIOCRUZ, 2002. 
WISNER, Katherine L.; DOLAN-SEWELL, Regina. Por que o gênero importa? In: NARROW, William E.; FIRST, Michael B.; SIROVATKA, Paul J.; REGIER, Darrel A. (org.). Gênero e Idade: Considerações no diagnóstico psiquiátrico. São Paulo: Roca, 2008. p. 6-17.

YANNOULAS, Silvia Cristina. Gênero e mercado de trabalho: situando a problemática. YANNOULAS, Silvia C. (coord.). A convidada de pedra: mulheres e políticas públicas de trabalho e renda. Brasília, FLACSO, 2003. p. 48- 62. $16,1994$.

Iguais mas não idênticos. Estudos Feministas, Florianópolis, v. 2, n. 3, p. 7 -

ZANELLO, Valeska; SILVA, René Marc Costa e. Saúde mental, gênero e violência estrutural. Revista Bioética, Brasília, v. 20, n. 2, p. 267-279, 2012. 